\title{
Historical American
}

\section{Engineering Record - Idaho} National Engineering and Environmental Laboratory Test Area North, HAER No. ID33-E

February 2005

Idaho National Engineering and Environmental Laboratory Bechtel BWXT Idaho, LLC 


\section{Historical American Engineering Record}

\section{Idaho National Engineering and Environmental Laboratory}

Test Area North

HAER No. ID-33-E

February 2005

Idaho National Engineering and Environmental Laboratory

Idaho Falls, Idaho 83415

Prepared for the U.S. Department of Energy

Under DOE Idaho Operations Office

Contract DE-AC07-99ID13727 
HISTORICAL AMERICAN ENGINEERING RECORD

IDAHO NATIONAL ENGINEERING AND ENVIRONMENTAL LABORATORY

TEST AREA NORTH

HAER NO. ID-33-E

Location: Within the Idaho National Engineering and Environmental Laboratory, approximately 45 miles northwest of Idaho Falls, Idaho, Butte and Jefferson Counties, Sections 11 and 13, T 6 N, R 31 E, and Section 19, T 6 N, R 32 E, Boise Meridian.

Date of Construction: 1952-1970

Architect/Engineer: Ralph M. Parsons Company, Kaiser Engineers

Builder: Various: Utah Construction Company, Howard S. Wright Construction Company, Arrington Construction Company, M.W. Kellogg Company

Present Owner: United States Department of Energy

Present Use: Vacant; Specific Manufacturing Capabilities Project

Significance: Test Area North (TAN) was a site of the Aircraft Nuclear Propulsion (ANP) Project of the U.S. Air Force and the Atomic Energy Commission. Its Cold War mission was to develop a turbojet bomber propelled by nuclear power. The project was part of an arms race. Test activities took place in five areas at TAN. The Assembly \& Maintenance area was a shop and hot cell complex. Nuclear tests ran at the Initial Engine Test area. Low-power test reactors operated at a third cluster. The fourth area was for Administration. A Flight Engine Test facility (hangar) was built to house the anticipated nuclear-powered aircraft.

Experiments between 1955-1961 proved that a nuclear reactor could power a jet engine, but President John F. Kennedy canceled the project in March 1961. ANP facilities were adapted for new reactor projects, the most important of which were Loss of Fluid Tests (LOFT), part of an international safety program for commercial power reactors.

Other projects included NASA's Systems for Nuclear Auxiliary Power and storage of Three Mile Island meltdown debris. National missions for TAN in reactor research and safety research have expired; demolition of historic TAN buildings is underway.

Report prepared by: Susan M. Stacy 
1718 North 17th Street

Boise, Idaho 83702

Date: $\quad$ November 30,2004

TABLE OF CONTENTS

Part 1 Introduction to Test Area North Page 5

Part 2 The Imperative for Radioactive Shielding Page 12

Part 3 The Mission of the ANP Project Page 18

Part 4 The Ralph M. Parsons Company Page 23

Part 5 The ANP "Heater" Reactors Page 26

Part 6 Siting and Building the IET Page 30

Part 7 The Assembly and Maintenance Area Page 52

$\begin{array}{lll}\text { Part } 8 & \text { The Administrative Area } & \text { Page } 77\end{array}$

Part 9 The Low Power Test Area Page 84

Part 10 The Shield Test Facility Page 95

Part 11 Maritime Reactor Program at TAN Page 102

Part 12 The Experimental Beryllium Oxide Reactor Page 104

Part 13 The Flight Engine Test Facility Page 111

Part 14 The Loss of Fluid Test Program Page 116

Part 15 Conclusion: Test Area North After LOFT Page 134

Appendix A: Vicinity Map for TAN Area $\quad$ Page 138

Appendix B: Plot Plan for ANP Areas Page 139

Appendix C: HTRE Runs at the IET Page 144

$\begin{array}{ll}\text { Appendix D: LOFT Experiments } & \text { Page } 146\end{array}$

$\begin{array}{ll}\text { Appendix E: Reactors Located at TAN } & \text { Page } 147\end{array}$

Appendix F: Shielding Materials Page 149

$\begin{array}{ll}\text { Bibliography } & \text { Page } 153\end{array}$ 
FIGURES

Front: Schematic diagram of HTRE-1

Page 4
Page 8
Page 18
Page 27
Page 34
Page 37
Page 39
Page 51
Page 55
Page 59
Page 67
Page 79
Page 128
Page 80
Page 82
Page 91
Page 94
Page 126
Page 127
Pa 126
Pa

1. Test Area North and Wind Rose

2. NEPA Project logo circa 1947

3. HTRE-1 Cylindrical Fuel Elements

4. View of IET from rail track

5. Schematic of IET

6. HTRE-1 Rig on Turntable

7. SNAPTRAN assembly

8. Schematic of $A \& M$

9. Interior of Hot Shop

10. Actuator mechanism lockers

11. Admin Building and Guard Station

12. Admin Building and Guard Station

13. Dispensary in 2003

14. LPT Guard House

15. HOTCE reactor

16. LOFT experiment configuration

17. Interior of LOFT pre-amp building

18. LOFT Borated water tank

19. LOFT Compressor building

20. Shielded roadway at EET/LOFT

Page 137 
Schematic diagram of HTRE-1 aerothermal and control systems. The Aircraft Nuclear Propulsion Program sought to combine a nuclear reactor with a turbojet engine and produce an airplane that was 
sufficiently light enough to take off and sufficiently shielded to protect the crew during flight. Source: APEX-901, p. 40. 
PART ONE

INTRODUCTION TO TEST AREA NORTH

The Atomic Energy Commission (AEC) established the National Reactor Testing station (NRTS) in 1949 as a place for the safe conduct of reactor tests and experiments. It selected a desert site in eastern Idaho on the Snake River Plain for its abundant supply of subsurface water and its relative isolation from densely populated settlements. The land already was in public ownership because the United States Navy had acquired it during World War II for use as a proving ground in connection with its Pocatello Ordnance Depot. The AEC purchased the land from the Navy and adapted it for nuclear reactor experiments. ${ }^{1}$

The NRTS presently consists of about 890 square miles. Its name was changed to Idaho National Engineering Laboratory (INEL) in 1974 and then to Idaho National Engineering and Environmental Laboratory (INEEL) in 1997.2 The AEC was replaced by the Energy Research and Development Administration (ERDA) in 1974; ERDA, by the Department of Energy (DOE) in 1977. The regulatory and reactor licensing functions originally within the AEC now reside in a separate agency, the Nuclear Regulatory Commission (NRC) . Local custom in Idaho has consistently distinguished Idaho Falls' in-town facilities from the desert venue by referring to the latter as "the site."

Among the early mix of military and peaceful missions for nuclear reactors, the business of the NRTS was to build and operate different types of reactors, demonstrate their utility, and then, in the case of "peaceful" uses, disseminate knowledge about them to commercial interests. The United States congress wanted to foster a commercial nuclear power industry. Much of the testing and experimentation at the NRTS aimed to develop reactor fuels, suitable reactor materials, and safe reactors. In the years after 1949, a vast program of research and experimentation investigated alternative types of reactors and the parameters for their safe operation. 3 
The Cold War between the United States and the Union of Soviet Socialist Republics (USSR) brought a number of military projects to the NRTS. Each nation wished to assure itself a superior position in the control of weapons, particularly nuclear weapons. The competition between the two countries for weapons supremacy launched an arms race that had the significant consequence of opening new operational areas at the NRTS.

By the end of World War II, the only nuclear weapon that had been developed (and used) was the atomic bomb. However, military planners envisioned nuclear power for the propulsion of submarines and jet bombers. As soon as the war ended, the U.S. Navy and the U.S. Air Force each advocated that research begin immediately into nuclear propulsion.

Both services obtained the support of the AEC and the U.S. Congress in authorizing and funding the requisite nuclear research. Private contractors conducted the research, built laboratories, and began their experiments. The Navy went on to produce nuclear powered submarines and surface ships. The Air Force expected to produce a nuclear powered turbojet airplane but, ultimately, did not reach its goal.

For both services, the AEC directed that the nuclear reactor experiments take place at the NRTS. The Navy hired Westinghouse Corporation to develop the Naval Reactors Facility, and the Air Force hired General Electric (GE) to develop the Aircraft Nuclear

Propulsion Project (ANP) at the area now known as Test Area North. 4

Of the two services, the Navy was the first to arrive in Idaho, breaking ground on its first reactor building in August of 1950.5 This building, along with its cooling tower and other support facilities created a new center of activity to join the four others also under construction at the time -- the central Facilities Area (CFA), the Test Reactor Area, the EBR-1 complex, and the Idaho Chemical Processing Plant (now named Idaho Nuclear Technology and Engineering Center, or INTEC).

These five clusters were located in the southwest portion of the NRTS. The Navy's old proving ground buildings was adapted as a central services area dedicated to site-wide functions such as warehousing, craft shops, records management, health physics support, fire suppression, and security. EBR-I was south of CFA. The Chemical Processing Plant and the Test Reactor Area were about five miles north of CFA, and the Navy's establishment was another five miles to the north along a connecting road named Lincoln Boulevard. 
The NRTS had a Site Selection Committee whose responsibility was to assign locations for various reactor projects. The committee considered the consequences both of normal operations and potential accidents in which radioactivity might be released into the air. To that end, the NRTS established a Weather Bureau Station at the site in 1949 and began accumulating meteorological data. The committee took account of annual and diurnal patterns of prevailing winds across the desert. For most of the year, prevailing daytime winds came from the southwest. 6

The siting criteria also considered the power level at which a proposed reactor was expected to operate. The higher the power, the more distance (measured in miles) was required between reactors. Reactor buildings were arranged so that if an accident 
Figure 1. Direction and frequency of the wind was a major environmental influence in the siting of reactors of the Aircraft Nuclear Propulsion program. The row of reactor buildings -- FET, IET, and LPT/STF -- are roughly perpendicular to a wind direction from southwest to northeast. Locations marked Proposed Runway, Future PSTF, and Future STAF were never built. Source: Luke and Gilliland, Hazards Summary Report for Susie Reactor, p. 8. 
were to release radioactive gases or particles into the air, the prevailing winds would not carry them in the direction of other reactors, work areas, or "civilians" outside the NRTS boundaries. Within the ANP area, where several reactors were to be operating, the prevailing wind also determined the geographical relationships among them.

When Congressional authorization and funding for the Air Force's ANP program came together in 1951-52, its General Electric and Air Force managers desired as much isolation at the site as possible and were not interested in using the site's central services.7 In the Cold War, secrecy was valuable. In addition, they were planning for reactor experiments to take place outside in the open air, an excellent reason for putting distance between the ANP and other NRTS activity areas. The Site Selection Committee allowed the project to occupy the far northeast corner of the site. In 1952-1953, the old Navy trail known as Lincoln Boulevard was extended and paved to TAN, a distance of about twenty-seven miles from the Central Facilities Area.

TAN is situated on fairly flat ground. Basalt rock lies beneath most of the site, covered by varying depths of sand, silt, and gravel. To the north and west, the mountains of the Lemhi Range rise to create a panoramic background. A stream called Birch Creek flows from the eastern slope of the Lemhis; its waters are either diverted for hydroelectric power production or sink into the soil and disappear into the aquifer. 8 Flooding of the ANP area was considered to be a rare event, but possible. GE's architects contended with this eventuality in determining the elevations of tank storage buildings and other structures. 9

The flat contours of the site are interrupted by remnant features of ancient fresh-water Terreton Lake, the ancestor of modern Mud Lake. Geologists in 1952 described one of these as a "sinuous sand bar" running in a north/south direction. It formed a low ridge about 25 feet high, with higher ground to its east and an escarpment facing the flat long-since-dry lakebed toward the west.10 Later geologists decided that this feature actually was a shoreline of the ancient lake.11 ANP builders enlisted this feature as an element in nuclear-age architecture. See HAER Photo No. ID-33-E-111.

Lincoln Boulevard brings traffic from the rest of INEEL around the eastern edge of (most of) TAN, continues east, and joins Idaho state Highway 33, exiting INEEL about ten miles from TAN. Not far from the INEEL boundary lie the small settlements of Mud Lake and Terreton. Still farther east, Highway 33 intersects Interstate 15 at Sage Junction, which takes a traveler south to Idaho Falls or north to Dubois, Idaho, and the Montana border. 
As General Electric considered their planned experiments, the various reactors they would be testing or using, and the required non-nuclear support facilities, they realized they would have to subdivide their corner of the site into distinct working areas separated from one another by appropriate safety distances. They began at first with four such operating areas and later added a fifth. These five clusters of buildings and structures compose TAN, connected variously by roads, electrical and communication lines, and rail track. They retained their identity for the next fifty years; no others were added. Surrounding each cluster was a chain link security or exclusion fence.12

This Historic American Engineering Record (HAER) on TAN is being prepared because DOE has decided that no further missions remain for most of the buildings in these clusters. For many years, DOE has been cleaning up or remediating hazardous waste sites at TAN (and at other locations at the site). Since 2002, DOE and its contractor Bechtel BWXT-Idaho have been

"accelerating" this remediation. The proposed activities include the removal of all decommissioned buildings, nuclear and non-nuclear alike, historical and non-historical alike.13

Historical analyses prepared in the last five years have assessed NRTS nuclear research activities that occurred between 1949-1970 as exceptionally significant in American history even though the buildings connected with them are not fifty years old. 14 Based on this assessment, the INEEL Historic Architectural Properties Management Plan for U.S. Department of Energy, Idaho operations Office classified several historic buildings as "key individual properties" potentially eligible for listing on the National Register of Historic Places. Several "key" properties are located at TAN. Following consultation with the Idaho state Historical Preservation Office and the Advisory Council on Historic Preservation, DOE agreed to mitigate for the demolition of historic TAN properties by recording them in the format of a Historic American Engineering Record.15

This is the second HAER to mitigate for the alteration or destruction of historic TAN properties. The first was prepared in 1995 when DOE planned to modify the roof of TAN-629, the ANP hangar built to house the anticipated nuclear powered bomber. In addition to a detailed record of the hangar, that report contains a history of the ANP program, its origins, the political tensions that influenced its progress, and its major achievements and significance. The present report will not repeat that material, but rather focus on the functional and architectural features of the entire ANP complex, supplementing the earlier historical account as appropriate. ${ }^{16}$ 


\section{PART TWO}

\section{THE IMPERATIVE FOR RADIOACTIVE SHIELDING}

AEC Commissioner Sumner Pike once said, in justifying the creation of the NRTS in a remote desert location, that the AEC "didn't want to put work like this next to a high school."17 "Work like this" was experimental work with radioactive materials and nuclear reactors. The art of placing work activities in safe relationships to one another was a young one in 1951 when the architects sat down to design the ANP work areas. Nuclear facilities had a history on the earth of less than ten years.

Before embarking on a tour of historic Test Area North, it is well to review the salient behaviors of reactors, radioactive materials, and their potential to harm people and the environment, particularly as these were understood early in the $1950 \mathrm{~s}$.

Atoms are conveniently visualized as small solar systems, consisting of a central nucleus containing neutrons and protons in the position of the sun. Electrons circle the nucleus. Electrons and protons have opposite electrical charges. Neutrons have no charge, but add weight to the atom. The atoms of each element contain a unique number of protons, which give the element its identity as carbon, mercury, lithium, or other matter. In nature, each and every atom of the same element may not contain the same number of neutrons. When they do not, each specie of the atom is called an isotope. The isotope lithium-7, for example, has one more neutron than the isotope lithium-6.18

Most elements in nature are composed of "stable" atoms, in which the positive and negative charges are balanced. A lump of pure iron, for example, if left alone in a vacuum for a million years will be exactly the same element and weigh the same as it did in the beginning. However, uranium is not stable, and a lump of this element will not be the same in a million years. Its atoms spontaneously eject small parts of the nucleus. These particles flee from the atom into the surrounding matrix and/or environment. Depending on the particular element and isotope, particles ejecting from radioactive substances may be single electrons or helium nuclei, known as beta and alpha particles respectively. Some breakups also produce gamma rays, a form of electromagnetic energy similar to light but more energetic. Given enough time, a lump of uranium will transform into lead.

In nature, our "lump" of natural uranium is a mixture of two common isotopes. Most uranium atoms contain 238 protons and neutrons (U-238); however, for every 140 of these atoms, there is one atom with 235 protons and neutrons (U-235). 
The excitement of 20th Century physics was the discovery that when scientists bombard an atom of U-235 with neutrons, the atom splits into two roughly equal fragments, transforming the original uranium into pairs of elements such as barium and krypton. However, the split is neither neat nor tidy: small particles and rays flee from the atom -- one or two neutrons (sometimes three), miscellaneous electrons, alpha particles, and gamma rays. Among the results of the fission are the release of energy and heat. 19

A nuclear reactor is a device built to exploit two products of nuclear fission: neutrons and heat. If enough U-235 atoms are placed close together (in a mass said to be "critical"), the two or three liberated neutrons are likely to hit other uranium atoms and split them, keeping the process alive in a chain reaction. A continuing and sustained fissioning process generates continuing and sustained quantities of heat. For thousands of years, human society has used heat to do various kinds of work. Most pertinent to a nuclear powered airplane, the heat of fission could substitute for the combustion of chemical fuel. In a jet engine, hot compressed air is sent out a small nozzle for thrust.

The unhappy fact that fission is untidy complicates all of its useful possibilities and raises its cost. Gamma rays, for example, which leave the U-235 atom at up to 44 million miles per hour, penetrate matter very easily and go a long distance, only gradually slowing down depending upon what is in their path. If they enter the human body at certain speeds, they strip electrons from atoms in the molecules of human tissue. The fragments are called ions and represent an upset in the balance of electrical charges. These changes can produce cell mutations which in turn can cause cancer.20 When a safe distance from the source is not practical, blocking gamma rays requires an investment in various thicknesses of lead, concrete, earth, or water to absorb their energy.21 Neutrons can also penetrate deeply into the human body and damage tissue.

Alpha particles lack the energy of gamma rays. Colliding with the atoms in a few inches of air will stop them.22 A person can block them by wearing gloves or arranging a shield no thicker than a piece of paper. However, if the person inhales or ingests alpha-emitting substances, they may lodge in the lungs or bones, where they become an ionizing force damaging the surrounding tissue. Nuclear work spaces therefore exhibit careful investments in ventilation systems that carry alpha-emitting materials away from work areas.

Beta particles are faster and more energetic than alphas. But they have very little mass and can be stopped by a thin sheet of metal. Contact with human skin can cause burns, and inside the 
human body they can be as harmful as alphas.

The neutrons fleeing uranium atoms can induce radioactivity in elements that in nature are not radioactive. For example, a neutron that penetrates an atom of nitrogen in the air will transform it from a stable isotope to an unstable one that emits gamma rays, beta particles, and heat as it "decays." This secondary effect of uranium fission is potentially just as harmful to the human body as the primary one. Even after a reactor has been shut down, radioactive decay continues long after the chain reaction has been quenched. Within shield materials such as concrete, atoms near the surface of the shield that have been "activated" may emit secondary gamma rays that exit the shield entirely. Shield thickness merely reduces the odds of such an occurrence.

Another untidiness of fission is that the split uranium atom does not always result in barium and krypton, but any number of 200 other species of atoms, most of them radioactively unstable. These fission products require different amounts of time before they stabilize or "cool off" (decay). Some require less than a second; others, thousands of years. The time it takes for a substance to lose half of its "activity" is expressed as its "half-life." Until these substances have decayed, their emissions of alpha, beta, and gamma rays make them hazardous enough to require careful management. At nuclear reactor facilities, therefore, architect/engineers design systems for safely transporting, sampling, analyzing, storing, concentrating, and dispersing solid, liquid, and gaseous forms of radioactive "waste."

One characteristic of neutrons is that they can collide with the atoms of air gases or dust particles and deflect their course. Merely erecting a wall-like shield between the source and a work site will not necessarily protect workers from this type of scattering. Gamma rays and neutrons escape the fuel in all directions; a shield will slow down and absorb only the ones directly aimed at the shield. Neutrons that flee high into the air may be deflected back towards the ground, effectively jumping over the shield. When arranging the distances between work spaces and reactors, therefore, architect/engineers consult nuclear analysts who calculate the pathways of neutrons to determine safe separation distances. These calculations are one of the reasons that the five ANP activity areas have "distance" between them.23

Designing interior work spaces is another matter. Workers must assemble and manipulate components of reactors, be in visible contact with reactors, manage chain reactions, and move radioactive fuel elements from place to place without themselves receiving doses of ionizing radiation. Similarly, fission 
products have to be controlled so that air and water resources beyond the work space do not become contaminated and harm others at a later time in a distant place.

Since alpha and beta radiation are relatively easy to block, any device that absorbs gamma and neutron radiation will also block those. Thus, most shielding plans, calculations, and costs center on gamma and neutron radiation.

In the early 1950s, the medical understanding of how radiation harms the body had progressed passed several milestones since 1896, when French scientist Henri Becquerel discovered that uranium was radioactive. Workers who painted radium dials on clocks and watches in the 1920s tipped their fine brushes between their lips, bringing upon themselves early and tragic deaths. Scientific committees organized thereafter to determine what levels of exposure might not harm workers. In 1934, a "tolerance dose" was one that did not cause skin irritation. By the 1940s, the distinctions between external and internally deposited radiation were more clear. Standards were developed for both, and these served Manhattan Project workers producing the atomic bomb. After the bombs were dropped on Hiroshima and Nagasaki, radiation exposure became a public health issue, affecting populations far beyond industrial workers. Animal studies revealed that it was possible to inherit a genetic mutation induced by radiation exposure to reproductive organs. Protection concepts shifted quickly from a "tolerance dose" to a "maximum permissible dose" and an attitude of "the less exposure the better."24

Around 1951, protective standards for atomic workers made a distinction between "whole body" exposures and exposures to extremities such as fingers and feet. Handbooks setting standards for internal emitters would not be published until 1953, but "body burdens" of various materials were known. To protect the environment, recommended standards indicated permissible concentrations in air or water. When these were published, the handbooks contained long lists of isotopes and an allowable concentration for each in air or water.25 In effect, a concentration limit implied that a radioactive material might be discharged into the air or water provided it was sufficiently diluted by the time it reached its point of human contact. Since an experimental nuclear airplane engine would discharge contaminated air directly into the NRTS environment, the role of the wind in diluting air-borne contaminants was of intense interest to architect/engineers.

As GE embarked upon its project for the Air Force, the protective standard for the AEC's nuclear workers was expressed as no more than 0.3 Roentgens of exposure to the "whole body" during a six-day work week. 26 Units of measurement eventually 
became more diverse in order to differentiate among the ionizing power of gamma rays, radiation doses that human tissue would actually absorb, and the injury likely to be caused by a dose. Instead of using Roentgens (a quantity of X-rays that would produce a specified degree of ionization under certain conditions), the work standard was expressed as a "rem" (roentgen equivalent man). The rem expresses the likely biological injury resulting from an exposure.27 During the 1950s, both of these expressions were in use.

Maximum permissible exposures in rems were described in Handbook 59, published by the National Bureau of Standards in 1954. However, the recommendations of the national and international committees that had been studying the effects of radiation since the $1920 \mathrm{~s}$ were understood prior to this date.28 Thus, the architect/engineers for the nuclear airplane project had to meet certain standards despite the fact that they had not been published formally.

The maximum permissible exposure of the whole body to external sources of ionizing radiation was expressed as 300 millirems per work week. 29 In designing work spaces, the architect/engineers had to understand what type of nuclear experiments and activities were expected in various work locations. Health physicists helped evaluate the threats these activities could pose to workers. Further, they considered the nature and consequences of errors, mistakes, accidents, equipment failures, earthquakes, and floods. These concerns, together with a goal to keep dose rates below the maximum permissible, called for an architecture of shielding at Test Area North.

\section{PART THREE}

\section{THE MISSION OF THE ANP PROJECT}

The basic mission of the ANP project was to prove that a turbojet aircraft engine could run on nuclear power. If so, the mission would evolve to create a reactor/engine power plant that could actually fit into an airplane, fly the airplane, run reliably on a military mission, and be shielded somehow to protect the pilot, crew, and ground personnel from harm. The Air Force called its ultimate goal Weapon system 125-A, a term embracing all of the inter-related technology, the airframe, resources, ground facilities, supply chains, and trained human talent required to launch and carry out a combat mission.

Figure 2. NEPA Project logo circa 1947 The Air Force already had an idea of the many technical 
barriers in the way of achieving its goal. Beginning in May 1946, it had authorized a group of engineers to go to Oak Ridge, organized under the name Nuclear Energy for the Propulsion of Aircraft (NEPA), and begin studying the feasibility of the project. Most NEPA work was strictly on paper, the working out of problems in mathematical and physics analysis, reactor design, radiation damage, and shielding. The group faced the fact that no reactor built to date had been designed to operate at extremely high temperatures. What kind of structural materials and reactor fuel would withstand the corrosive insults of high heat, high pressure, and radioactivity? The central problem was to transfer enough heat from the reactor to the engine to lift the plane, propel it, and give it speed. Thus, high heat was at odds with preserving the reactor fuel. Protecting the crew was a collateral concern. The airplane had to be light enough to fly, but shielding materials were notoriously heavy.30

The NEPA group developed two general ideas about how to transfer heat to the engine. In the "direct cycle" approach, the transfer medium was ordinary air that would flow through the reactor core and absorb heat directly from the fuel elements. Heat expands the air, increasing its pressure. It would pass through the turbine and be expelled through the exhaust nozzle. As usual, things would not be tidy. In its passage through the reactor, the atoms of air gases (such as nitrogen and argon) were likely to absorb neutrons and become radioactive isotopes. Any dust particles or moisture that happened to be in the air would also be subject to change. The exhaust would introduce radioactive contamination into the atmosphere. Gamma rays and streams of neutrons along with the other usual fission products would pose their usual hazards. 31

The other idea was an "indirect cycle," which provided an intermediate heat exchanger between the air and the reactor. A liquid metal, contained in a closed loop of piping, would flow through the reactor core to absorb heat. Acting as a radiator, this hot metal would give up its heat to the exhaust air. The liquid metal would return to the reactor to be reheated. This was the cleaner of the two designs. The reactor could be smaller and require less shielding, but its engineering would have to be far more complex and precise. The "liquid metal" was, as yet, hypothetical; no reactor to date had been cooled by a liquid metal.

The Air Force and the AEC decided to pursue both concepts simultaneously. It hired General Electric to develop the direct approach, the simpler of the two to engineer, but just as difficult to make succeed. Air is a poor absorber of heat; therefore a very large volume of air would have to pass through the reactor in order to absorb the energy required to fly the 
plane. The reactor would have to be relatively large and bulky. The reactor fuel would have to be made of such sturdy stuff that it could survive temperatures up to and higher than 2000 degrees F. without itself burning up -- a material that had not yet been discovered or devised. 32

Up to this time, all the reactors in the United states had been built to be immobile, not operate within a moving object like an airplane. Immobile reactors could be planted in one place, then surrounded with shielding. Space and weight were not constraints, so thick walls of (relatively inexpensive) concrete served as shields. Experience at Hanford, Oak Ridge, and elsewhere had produced a body of knowledge about the types and thicknesses of materials that could do the job.

GE already had experience with standard shielding. In 1946 it had become the AEC's prime contractor at Hanford Engineer Works. Here, GE scientists studied reactor design, radiobiology, radiological and meteorological monitoring, and related fields. When the AEC expanded Hanford for increased plutonium production as the cold War began, GE built the reactor and production areas known as 100 DR and 100-H. Architect/engineers for these facilities had produced 2,500 drawings.33 The drawings that would accumulate for ANP would reach well beyond a thousand. Managerial experience with nuclear work counted for something, and GE clearly was a leader in nuclear technology by 1951. The ANP challenge was to advance the technology for shielding mobile reactors.

Designing its Idaho facilities, GE engineers had to imagine the journeys that its reactor/engine would take around the site. Merely to prove the principle one time, engineers would assemble the reactor/engine in a large shop, move it outside somewhere to a test pad, bring the reactor to criticality, then to full power, measure the transfer of heat to the air (and many other operating parameters), and demonstrate that it ran the engine. Hot air would exit the jet nozzle. Even though the test assembly would be outdoors, the humans at the control center could not be. Gamma rays would flow and the exhaust would be contaminated, so no one could be exposed anywhere near the experiment during or in the hours immediately after it took place. The first run would begin with a clean reactor and clean engine, but after its first operation -- at the "initial engine test" area -- radioactive air would have blown through the engine, contaminating it. This complicated the procedures for moving the engine back to the shop. Moving any given assembly to the pad for its first test would be safe enough, but hauling it back and forth thereafter would be another matter.

The shop area had to encompass a wide range of crafts and 
laboratories to prepare the experiment before its initial test and all subsequent tests. The reactor would need periodic refueling; workers would have to examine, handle, and store spent fuel elements somewhere. The jet engine would need its own tests, not to mention chemical fuel, regular maintenance, and servicing. After an assembly was contaminated and/or partly radioactive, workers would need to disassemble it, extract measuring and data instruments, examine components, evaluate failures and problems, and prepare for more refined experiments -- without getting doses of radiation. This called for a wide array of remotely operated handling tools. The reactor/engine assembly would certainly be heavy; it was likely to be as tall as a three-story building, so the shop containing it and overhead cranes would be quite large. The test pad and the shop/laboratory complex would have to be at a suitable distance from the test area to protect shop workers while the reactor was running outside.

GE expected it would need small reactors (other than the airplane reactor) as tools to support the main mission. As the project began, GE did not know the optimum materials or shape of the airplane reactor's nuclear fuel elements. Given a particular arrangement of elements in the core of the reactor, how much fuel would be needed for a critical mass? What were the nuclear characteristics of fuel configurations? Investigators performed "critical experiments" to answer these and related questions about how best to control or quench the chain reaction. Such studies used very low-power reactors -- so low that they generated practically no heat and required no great effort to remove it. As reactors went, low-power reactors were cheap.34

In addition, research on the problem of shielding the crew needed to continue. A low-power reactor would be useful for this as well. Using safety distance formulae, low-power reactors had to be located away from the engine test area and the laboratory complex. Thus, a low-power test area was TAN's third subdivision.

GE expected to employ hundreds of people to run and support the experiments. Situated as far as they were from the NRTS services at CFA, employees would need a dispensary, cafeteria, change rooms, security, and other services. Management needed its Idaho headquarters. The fourth area was defined, therefore, as an administrative area. Its workers would not be engaged in nuclear work directly, so their offices would be "cold" areas.

When the ANP program had evolved well past the point of proving the principle, it appeared that an airplane might become a reality. GE planned a fifth area to house such an airplane in a hangar. It would be large and equipped to service the reactor, the engine, the crew, and the rest of the airplane. Similar to the initial engine test, the craft would begin clean, but after 
its first flight would be contaminated. A shielded control room and methods of remote operation would be required here as well.35

GE ultimately would need one final asset to perfect its mission -- a runway for the airplane. Aside from being flat, the runway had to be arranged so that an arriving or departing airplane could be observed from all directions and be in a suitable relationship to prevailing winds. If the aircraft were disabled or crippled, workers had to be protected from the consequences of accidents or rough landings. The craft would be burdened with shielding, so the runway would need to be heavily reinforced and at least four miles long.

The five areas were named Initial Engine Test, Assembly and Maintenance, Low Power Test, Administration and Service, and Flight Engine Test. These areas quickly assumed acronyms in everyday use: IET, A\&M, Admin. The Low Power Test sometimes was referred to as the Susie area. The Flight Engine Test area was referred to as the FET, or simply as the TAN Hangar area. ${ }^{6}$

The ANP project would need the usual support utilities: connecting roads, sewage treatment plants, water supply, electricity, meteorological stations, security fencing, telemetry towers, and communication lines. Following a practice used at other industrial plants, GE decided on a locomotive and railroad system for hauling the heavy reactor assembly from place to place. However, the details for adapting the locomotive, dolly, and tracks for hot nuclear cargo would be anything but usual.

The Air Force and GE had every confidence that many more nuclear tests would follow the "initial" one, and that the mission would continue until an aircraft took to the skies. They designed Test Area North for an enduring series of experiments and left plenty of room for expansion.

\section{PART FOUR}

\section{THE RALPH M. PARSONS COMPANY}

GE's headquarters for the ANP project was at Evendale, Ohio, near Cincinnati. In 1951 it was preparing this facility for the work to come. 37 The company would design the reactor here, assemble it, and develop the various tasks required before ground tests could begin elsewhere. It built new laboratories, shops, and offices, converting older buildings from obsolete uses, and erecting new ones.38 Until the AEC decided where ground testing would take place, GE referred to it as "the Remote Site." Once in Idaho, GE called it the "Idaho Test Station." 
As soon as it was evident that the Remote site was going to be the NRTS, GE hired the Ralph M. Parsons Company to survey the site and determine its feasibility for the expected work. Parsons joint-ventured with other industrial firms as the

Parsons-Macco-Kiewitt Corporation. GE had been evaluating various alternatives of the general layout, still undecided as to how concentrated or dispersed the various functions would be. It discussed these with Parsons along with an appropriate "philosophy of shielding personnel vs. the reactor."39

Many Parsons employees and construction managers already had security clearances and were familiar with government procedures. Even its California headquarters office contained security-cleared drafting, laboratory, and office areas.40 The company founder, Ralph M. Parsons, had joined the Bechtel-McCone Corporation in 1937 and become a principal in 1938, when the company added his name to the title. Parsons had brought to the group a specialty (and patents) in petroleum refineries and chemical industries. The group's innovative force was to offer a full range of design and construction services for complete industrial plants and all their appurtenances; the client was relieved of the management overburden of dealing with a multitude of contractors and subcontractors for each component of an enterprise.41 During World War II Parsons acquired experience in aeronautical engineering. In 1944, he withdrew from Bechtel-McCone-Parsons and organized his own company with headquarters in Los Angeles, California, where he continued to seek work with private industry, the military, and governments.42

For the site survey, which began in the fall of 1951, Parsons investigated the lay of the land, potential water supply, the geological characteristics of the aquifer beneath TAN, potential contamination hazards, availability of electrical power, waste disposal options, the climate, and means of securing the site.43

In June 1952, GE recommended that the AEC select the Ralph M. Parsons Company to provide a master plan and follow up with detailed designs for the Idaho station. The AEC agreed, and Parsons began immediately to design a fully integrated test facility for Aircraft Nuclear Propulsion. Among Parsons' chief engineers, architects, and managers were Nick W. Bolotin (senior architect), O.R. Garrett (chief mechanical specialist for shield doors, handling dollies, remote handling equipment), William A. Jack (manager), David C. McDowell (resident manager of construction at NRTS), Robert E. McMeen (project engineer for FET), Gordon C. Murray (resident engineer and assistant project engineer), William A. Siegrist (engineer), Harry Wilson (operating manuals and specifications engineer), J.J. Wodal (piping engineer), James R. Young (project engineer), Leo H. 
Barbour (exterior design). 44

Construction drawings began to emerge from Parsons drafting rooms by the end of 1952. Plans for the A\&M area bear the earliest dates. Resources were allocated such that the first halves of the A\&M and Admin buildings were built first and then "expanded" in a second construction phase. This scheme allowed beneficial work to begin while construction took place simultaneously. By the time the enlarged facilities were ready, the pace of research and testing had accelerated. New personnel fit right in to the new spaces. 45

PART FIVE

\section{THE ANP "HEATER" REACTORS}

GE assembled the first reactor/engine rig during 1955, made the reactor critical for the first time in November, and proved the principle of jet operation in January 1956. Test runs continued through 1956, some lasting more than 100 hours of continuous operation. Each test was different than the previous one, but a chief point of interest always was the temperature of the fuel and how much heat had been transferred to the air exiting the reactor core. The tests usually involved running the reactor on both chemical and reactor fuel. During early tests, for example, the engine was started on chemical fuel and gradually switched to reactor operation. Later runs started the engine solely on reactor fuel.46

A reactor/engine assembly was officially called a Heat Transfer Reactor Experiment, or HTRE, pronounced "heater." During the course of the ANP program, GE built two assemblies. The first, HTRE-1, connected the reactor to one (modified) J-47 jet engine. The experiment made no design concessions to its future home inside an aircraft fuselage. It was bulky, equipped with access ladders and platforms for the convenience of the workers assembling the ducts, connections, and instrumentation devices.

The design and materials for the reactor core of HTRE-1 was under constant review and development almost to the month of its first run. Nevertheless, enough of its nuclear characteristics had been predicted and calculated so that the architect/engineers could design the appropriate shielding around the IET and A\&M work spaces.

The reactor, the heart of the HTRE, was wrapped like a jewel in ever-larger boxes. The uranium fuel was sandwiched between stainless steel cladding. These elements, arranged in concentric 
rings, were contained within a cylinder with a diameter of 5.25

feet and about three feet long. Air entered at one end and flowed between the elements, picking up the desired heat and cooling the reactor. Surrounding the cylinder, about 160 gallons of demineralized water provided additional cooling and also moderated the speed of neutrons leaving the fuel during a chain 
Figure 3. HTRE-1 reactor fuel was shaped in concentric rings to allow air to flow through and collect heat. The fuel cartridges stacked 18 fuel elements in a tube, which was then inserted into the reactor core. Source: Thornton and Rothstein, Comprehensive Technical Report, APEX-901, p.37, 39. 
reaction. Circulating fresh cool water into the reactor core would have to be one of the capabilities at the IET.

The next "box" was a shield in the shape of another cylinder, this with an outside diameter of ten feet and just over twelve feet long. This tank-like structure was made of iron and contained 4100 gallons of borated water. Boron is an element disposed to capture neutrons, taking them out of play for a chain reaction. This shield stopped neutron flux, but not gamma rays. Thus, gamma radiation was the chief (although not only) hazard dictating the shielding needs beyond the reactor. Neutrons were still expected to exit the engine jets with the exhaust.47

The 4100 gallons of water were drained after an experiment. This chore took place after the reactor had been hauled back to the A\&M building, and never before the reactor had been shut down and cooled off for at least one day. 48 However, when the pace of experimentation picked up, workers thought one day was too long to wait, so they did things differently. Richard Meservey, an ANP instrumentation engineer, recalled:

As soon as a test was finished, they drained the water from the annulus [the space between the inner and outer cylinders] and pumped the space full of mercury. Mercury is a high-density material, and it made a great shield. It allowed the workers to climb back up on the assembly sooner to change out the instrumentation or make other adjustments. The mercury reduced their exposure. They didn't have to wait for the short-lived isotopes to decay away. As soon as they were finished changing the instruments, they would drain out the mercury and pump water back in. Then they'd haul the reactor back down the track to the coupling station [IET] and run another test.

We had three-quarters of the free world's supply of mercury here at the site at one time. We had so much, that when the program was over, we had to release it slowly back on the market so that it wouldn't cause an economic upheaval. It wasn't radioactive because the mercury wasn't in the annulus when the reactor was running, so it wasn't irradiated. 49

Storing and disposing of the irradiated water after each run dictated that the A\&M facility be equipped with pumps, piping, and storage tanks to handle, hold, and dispose of it.

The operating life of a fuel loading was expected to last about 100 hours, during which time the uranium atoms would decrease and the krypton, barium, and other fission products would increase. If a fuel element ruptured toward the end of a 
run, the jet exhaust would release to the atmosphere a bigger inventory of dangerous materials than if the accident had happened during the first hour. When analysts designed shielding requirements, they were conservative; that is, they assumed an accidental rupture would occur at the end of a run, not the beginning. Similarly, for design purposes, they assumed a power level of $200,000 \mathrm{kw}$, for example, rather than the expected IET operation of $75,000 \mathrm{kw}$. The IET support facility had to tolerate and accommodate the heat, vibration, noise, and radiation produced during such a test. 50

After its year of tests, HTRE-1 was adapted for use as a materials test reactor. The ANP project had relied on the Materials Test Reactor (MTR) at the NRTS for this purpose, but the MTR was in great demand, and the ANP project was competing with many other customers, including the U.S. Navy, which was developing nuclear propulsion for ships and submarines. NRTS was developing a second test reactor, but it was not yet on line. GE redesigned the core of HTRE-1 so that samples could be inserted in the midst of the neutron flux. Its first specimen was irradiated in July 1957. The reactor's new name was HTRE-2.51

HTRE-3 was a completely new reactor/engine rig. Instead of running with one J-47, it ran with two. The fuel had improved. Instead of demineralized water, the moderator was zirconium-hydride, a solid material that could survive the high operating temperatures near the core. The overall profile of the rig was more horizontal, a closer approximation than HTRE-1 of how the thing might fit inside an airplane. HTRE-3 made its trips to the IET beginning in 1959 and continued through most of 1960 . After each test, the experimenters, GE, and the Air Force waited eagerly to learn how much heat the reactor had transferred to the $\operatorname{air} .52$

\section{PART SIX}

\section{SITING AND BUILDING THE INITIAL ENGINE TEST AREA}

The chief ANP innovation in the architecture of shielding was born of the necessity, especially at the IET, to "divide the shield" between the mobile reactor and stationary work places. The shielding around the outdoor reactor did little to block radiation in the stream of exhaust air. Shielded indoor spaces -combined with strict administrative rules on where and when people could be outside -- did the job.

\section{Siting}

The philosophy executed in the design of the IET was to place shielding chiefly around personnel, not the reactor. GE 
considered the IET design a unique "significant step forward in the development of mobile reactors." The IET was a forerunner of the far greater challenge of dividing the shield within an airplane between reactor and crew. Not only would radiation be a threat directly from the reactor, but also indirectly from the scattering of radiation that exited the fuselage of the plane, hit dust particles or air gas atoms, and bounced back into the cockpit area from outside. Some of the tests that GE planned at the IET concerned scattering effects of reactor operation, another reason for enclosing personnel in completely shielded work spaces. 53

Other than the danger implicit in any reactor experiment, the basic danger of outdoor operation was going to be the radioactive "particle problem." Running the reactor would send three types of particles into the air. GE health physicist C.C. Gamertsfelder, who defined the problem, projected that these would include small erosion fragments of the stainless steel cladding surrounded the fuel elements, a normal corrosion process in high operating temperatures. Likewise, any dust in the air going through the reactor core would become radioactive. The third type of particle would appear if the cladding completely failed or ruptured, allowing the fuel itself -- U-235 and whatever load of fission products had accumulated in the fuel -to escape up the stack. 54

Gamertsfelder analyzed the likely size of the rupture-product particles, how they would affect the skin and lungs of anyone exposed to them, their likely concentration in the air, the amount of radioactivity likely to be released, and the probability that anyone downwind would actually be exposed to the particles. He concluded that the reactor should operate only when the wind was blowing in a harmless direction, and only when the breeze was strong enough to carry it off and dilute it. Detecting a fuel rupture should be a task of instrumentation. A rupture would occasion an immediate reactor shutdown and end the run.

If there was a total of 20 ruptures in a year's time, then there would be [2x10-4] particles per person per year [in the direction of the prevailing wind]. This is the same order of magnitude as the chance that any one person will be killed in an automobile accident during a year. However, it is very improbable that every inhaled particle could cause a death. 55

Thus, weather patterns were the chief determinant as to how the ANP work clusters would relate to one another. Fortunately, the prevailing southwest-to-northeast direction placed none of the populated communities in the region in the path of wind-borne 
releases. Being near the northern border of NRTS, operations were less likely to impact other site activity. The northmost ANP cluster had to be the IET. Anyone who desired a visual reminder as to the direction of the prevailing wind had merely to look at the rail track leading to the IET: it ran parallel to this direction. 56

A very sparse population lived northeast of TAN. Sherman McGarry, a DOE health employee at the time of the ANP project who later wrote of his ANP experiences, knew one of the residents.

One old widowed rancher lived [up] that way and would not be intimidated to give up his living there, although at $25 \mathrm{mph}$, any radiation effect [on] him or his animals was far below unmonitored life [natural background radiation]. He was stubborn. 57

Having determined that the IET had to be located at a latitude north of the rest of the ANP, the next issue was the safety distance between the IET and the A\&M area. Nuclear analysis had determined that the separation should be 6000 feet, a little over a mile. Anyone out-of-doors within 6000 feet of IET could receive radiation above the permissible dose.58 Therefore, a fence surrounded the IET. It aided secrecy, but functioned more importantly as an "exclusion" fence, preventing ranging stock or people from wandering inadvertently too close during a test.59

\section{Layout}

To visualize the IET layout, readers should imagine the railroad journey of a HTRE from the A\&M building as if they were passengers inside the locomotive riding along with its two operators. The locomotive is heavily shielded, windows limited to the front and rear. It pulls the HTRE rig westward from the A\&M building on a double-wide dolly toward the railroad turntable. Because of the extraordinary weight of the loaded dolly, the track has four rails. The locomotive travels only on the two center rails, while the dolly rides on all four. The journey is slow. The locomotive's top speed when burdened with the HTRE is 3.5 miles per hour. However, it would be extremely inconvenient if any of the rails were to spread and cause a derailment, so the operator travels no faster than $2.5 \mathrm{mph}$. The locomotive remains in radio communication at all times with the IET control room and video-camera observers in the Hot Shop. 60

Having successfully maneuvered at the turntable so that the locomotive is pushing the rig (rather than pulling it) northward toward the IET, the driver arrives at the chain-link exclusion fence. With about a mile still to go, the rig passes through the remotely operated gate and continues to the test pad.61 On the horizon, lined up with the tracks, are an aluminum building shell 
and, behind it, an exhaust stack. To the right (east) of the aluminum building is a concrete retaining wall parallel to the track and to its right an earthwork form with a flat top. The earth is a shield cover for a buried, bunker-like control room.

IET features not visible from the railroad approach include the "coupling station," also directly ahead but covered by the aluminum building. Workers sometimes referred to it as the "quick-connect" or "quick disconnect" station. When the dolly and HTRE are nudged snugly into position against the coupling station, leads are "plugged in" to the support services needed during a test: electricity, cooling water, jet fuel, lubricant, compressed air, instrumentation, and others. Leads from the dolly fit quickly into receiving ports with the help of workers waiting in the station. The jet nozzles from the engine fit into the receiving end of ducts that will carry the exhaust into the stack 200 feet away.

On the north side of the control room are two small buildings. The one on the east (TAN-625) contains fuel transfer pumps. The other (TAN-627) shelters storage tanks. See HAER Photo No. ID-33-E-31. If the locomotive had a window on its right side, the occupants might be able to see the road coming from the direction of the A\&M building. The road disappears down a ramp into a shielded tunnel at the east end of the control building, where vehicles can park and turn around. Autos are brought inside to prevent radioactive particles falling onto them during a test. They are aimed for quick departure in the event an emergency suggests that evacuation would be wise.

The locomotive pauses at a position about 100 feet from the coupling station. The operator retracts a floor hatch in the cab that mates with a hatchway between the two center rails just below. The passengers disembark, climbing a ladder down the hatchway where they enter a tunnel angled toward the control room. The locomotive operators can wait in the control room or return to the $A \& M$. During 100-hour reactor runs, the hatch and tunnel allowed for shift changes. When it was time to haul the rig back to the A\&M after the test, the operator climbed back up into the cab, and proceeded, never exposed to radiation. See HAER Photo No. ID-33-E-56 (IET plot plan). 
Figure 4. View of the IET from the railroad. Dead ahead is the movable aluminum building (TAN-624). The coupling station and exhaust duct are directly behind it, out of view. The exhaust stack is 150 feet high. To the right is the earth shielding covering the control building. Note weather tower and railroad signal light. Source: INEEL Photo 62-6218. 
South of the control room is a steel-frame weather/telemetry tower painted in alternating bands of red and white. 62 GE hoped to send weather data directly from the experiment to receivers at the A\&M and the site's Central Facilities Area. Of these efforts, McGarry recalled:

Incidentally, the use of telemetry was in infant stage at the time and was not very successful in this application at IET. GE struggled a long period of time to make it work but ended up using the equipment (instrument racks) in the operations areas for their data. 63

The other facilities rounding out the IET layout were two fuel tanks buried below grade on the north side of the control room. One contained jet fuel; the other, diesel. The Arrington Construction Company built the IET facility.

The Mobile Test Building, TAN-624

The mobile test building, made of corrugated aluminum siding mounted to a frame of aluminum girders, protected the experiment from the weather. It had no floor. It had wheels and rolled on 250 feet of its own tracks if it had to be moved forward or backward. It also could be positioned over the HTRE rig and moved all the way back to A\&M. It had no role in shielding, although a fine water spray was available for fire suppression.64 One advantage of aluminum was that it was unlikely to absorb neutrons or become radioactive. For this reason, analysts recommended that "every effort should be made" to substitute aluminum for steel wherever possible for framing, scaffolding, pipes, and fixtures. Alloys containing copper were to be avoided.65

The most striking feature of the building was its shape. The front and rear facades show a pentagonal outline, with a low-pitched roof and walls that slope inward from the eave to the wheels. The building was 45 feet wide and 60 feet long. From ground level to the ridge line it was $441 / 2$ feet high. The doors, one in the front and one in the rear, had a clearance of 33 feet. They were motor-driven and fashioned in vertical panels to slide up into the top of the building. During an engine test, both doors were open while the HTRE rig was under test and hooked up to the coupling ports and exhaust duct. See HAER Photo Nos. ID-33-E-46 and ID-33-E-57 .

The framework inside supported banks of floodlights, closed-circuit television monitors, cameras, radiation dosimeters, and other instrumentation, all of which aided the bunkered crew to observe test progress or the emergence of a problem.66 of a typical test, McGarry wrote:

Four closed-circuit TV monitors were used to observe HTRE 
and engine operations. Two were on each side of the building observing the HTREs; fore and aft. A redundant system of two periscopes were installed from the operations bunker (like a submarine periscope), one on each side of the rigs, [so that individuals could observe] if the TVs did not work or to zoom in on a small area...67

Occasionally, the light-weight building was no match for the high winds of the desert. One day, the sides and roof were blown away. Another time, the wind lifted the entire building from its rails and dropped it on top of the control room bunker. The HTRE was in the A\&M at the time, and no one was hurt. 68

The Coupling Station

Located at the end of the four-rail track, the coupling station was the physical point of contact between the HTRE rig, its service requirements, the exhaust stack, and the control room. The utility leads from the reactor and jet engine plugged into their respective ports. Control wiring terminated at appropriate panels and display banks in the control room. 
Figure 5. General Electric schematic of the IET. Top: Relation-ship among track, tunnel between control room and coupling station, periscope tunnels. Artist omitted exhaust stack. Bottom: Hatch and ladder down which locomotive driver and passengers proceeded towards control room. Source: APEX-131, p. 8,14 . 
When approaching the front of the Coupling Station on the four-rail track, the structure looked somewhat like a large altar. It presented a horizontal profile 40 feet wide, a flat top, and a massive appearance. Sticking up on each side were the columnar shields surrounding the periscopes, an analog, perhaps, to the candlesticks on an altar. A slot in the back (north) wall was 28 feet wide and about 5 feet high provided an opening through which the tailcones of the jets connected to ducts leading to the exhaust stack. In the south wall, another opening, 22 feet wide, received the leads from the dolly. See section A in HAER Photo No. ID-33-E-58.

The coupling station had two levels. The top level (room 117) gave workers access to the dolly. See Section B of HAER Photo No. ID-33-E-58. The lower level contained a service room (room 116) with pipe sleeves and other equipment. From there, the path to the control room was via a tunnel with several sharp turns, a shielding feature called a labyrinth or maze. 69 The massiveness of the station was dictated by the dense shielding materials of its construction. The side and rear walls consisted of five feet of ordinary concrete. The surface was treated with a boron coating (gunite) to absorb neutrons.

The standard for shielding the personnel tunnels was specified at a dose no greater than 1 milli-Roentgen per hour (1 $\mathrm{mR} / \mathrm{hr})$. Given the position of the reactor so close to the coupling station, the shielding calculations required that the roof over the tunnels would consist of 16 feet of tamped earth over one foot of concrete. At 100 feet from the reactor, the depth of tamped earth could reduce to 8.5 feet. Where a tunnel passed under the railroad tracks, earth shielding was not practical, so the alternative was six feet of concrete. 70 Even with shielding, one operating rule said that people were not to enter the tunnel and go to the coupling station until the reactor had been shut off and cooled for at least 20 minutes. 71 
Figure 6. HTRE-1 on the A\&M Turntable. Shielded locomotive behind to the left. Tapered bar plug is at lower right of rig. Leads from the reactor are routed through pipe conduit and neatly organized in a row of "quick connect" fittings. The jet nozzles will fit into a slot in the coupling station wall and connect to ducts conveying hot radioactive exhaust up the stack. Source: Sherman McGarry notes and GE photo U-1190-9. 
The shielding for the coupling station roof had to be just as effective as the roof over the tunnels; however, excessive thickness was not practical because the jet nozzles had to fit through the slot. Roof shielding consisted of a steel plate 1.5 feet thick and an equal thickness of barytes concrete. Barytes is a mineral composed of barium sulfate and replaces the sand and gravel aggregate in ordinary concrete. 72 The material is denser than ordinary concrete and supplied equivalent shielding at a lesser thickness. 73

Engineers took considerable care in designing and improving the fittings connecting the HTRE rig, the dolly, the coupling station, and the movable building. Vibration was unavoidable during a run, and plug and jet openings provided outlets for radiation. Aside from careful shielding, the contacts needed to be mechanically secure to prevent the dolly pulling away from the building and the various plugs. ${ }^{74}$

The dolly was equipped with a tapered plug bar on the forward end of the dolly. The bar was about 19 feet wide, 1 foot high, and 1 foot thick.75 It mated with a matched recess in the wall of the coupling station, where the connect/disconnect fittings were located. (See HAER Photo No. ID-33-E-58, Section B, upper right of room 117. Compare with plug on HTRE rig as seen in photo on Page 41). After the bar was moved into position, a 15-inch-thick lead barrier was moved directly in front of the wall opening to protect workers who were connecting the lines. A steel overhang, two feet thick, shielded the plug region from direct radiation.

Pipes continued on their way out of the station through penetrations in the shield walls, into the earth, and to their source of service. The plug bar accommodated as many as 6000 electrical wires. These went downward to the lower level service room. They proceeded via cable trays into the control building in the same tunnel used by personnel. The lower level also had a ventilating system, a sump pump, combustible gas and heat detectors, and alarm horns. 76

The two motorized periscopes allowed for a view from the bunkered control room directly at the HTRE rig. The viewing and operating station for the periscopes was inside the control building from a position on the west wall behind the U-shaped control console. A pair of (periscope) tunnels penetrated the west wall of the control room and earth shield, and angled toward the periscopes. The roof above the tunnel was high-density concrete three feet thick.

The shielding surrounding the periscopes made them unique. Around the periscope tube and its casing was a layer of lead 
several inches thick. This was surrounded in turn by high-density concrete, boron-treated concrete, ordinary concrete, and an additional layer of boron-treated concrete as the outermost layer of shielding. The scanning head was covered by a removable concrete cap lined with steel and fitted with a lifting ring. It was shielded with lead and concrete to match the shielding thicknesses along the shaft. See HAER Photo No. ID-33-E-59.

Each periscope shaft extended above the test cell floor about 14 feet, counting the height of the cap. The scanning head had a track length of 90 degrees and a vertical movement of 60 degrees. 77 The periscopes were equipped with mirror boxes at the angle joint connecting the horizontal and vertical portions of the shaft. A service pit for each periscope was located beneath the shaft below the floor level of the service room. See HAER Photo Nos. ID-33-E-35, ID-33-E-38, ID-33-E-47, ID-33-E-58 ( section A), ID-33-E-59.

Accessories and fixtures within the coupling station included recessed lighting, junction boxes, cable trays, breakers, transformer, explosion-proof receptacles, starters for the periscope motors, telephone outlet, an ion chamber outlet (radiation detector), sump pump motor, exhaust fan, intercom, and space designated as room to expand for "future relay panel" and "future aircraft energizers." See HAER Photo No. ID-33-E-60.

The Duct and Stack

During an experiment, the jet exhaust went through a 214-foot-long duct to the stack. The engine's tailcone was connected to the duct by a spring-loaded flange, to which was attached a half-round silicone gasket. When operation commenced, the silicone heated and expanded, exerting a pressure of 340 pounds and securing the connection. 78

The duct ran above ground, supported by reinforced concrete braces on substantial footings. The centerline of the duct was about 13 feet above ground level. Each jet connected to a separate duct, each of which gradually widened to an internal diameter of about 30 inches. The two ducts joined together at a distance of 56.5 feet from the jets. Now with an internal diameter of 76 inches, the duct continued another 84.5 feet, where it turned at a slight angle to the west. Nearing the stack another 62 feet, the duct angled once more, this time 109 degrees toward the east, then entered the stack. Inside the stack, the duct angled upward, directing exhaust to the top of the stack.

The duct was made of stainless steel. At seams, the expansion joints anticipated temperatures ranging between -40 degrees $F$ and 1400 degrees F; thus, welds and their ring braces supported this range. The ring braces were made of structural 
steel. An explosion relief port was located just beyond the junction of the two jet ducts. The exhaust could be sampled. Sample lines led to a small shack just north of the stack. See HAER Photo No. ID-33-E-61.

The purpose of the stack was to elevate hot, radioactive gases exiting the jets during a test. Breezes at 150 feet above ground would, it was expected, carry the exhaust away from the IET and any other NRTS facilities, mixing and diluting it to concentration levels below the allowable maximums before the material crossed the boundary of the NRTS.

Between 1952 and 1954, when drawings were at last produced, GE scientists discussed the stack a great deal. One issue was how high to build it. They assumed the exhaust would be hot enough to continue rising once it left the stack. However, to make conservative estimates, they calculated the consequences should the gases not rise any further, but begin mixing and diluting at that level. In the end, they built the stack 150 feet high, but allowed that better data in the future might dictate additional height. Thus, the stack had a rather stout, even stubby, profile when seen from a distance. The top opening had an exterior diameter of 20 feet. 79 See HAER Photo No. ID-33-E-31.

Another issue was whether or not to filter the exhaust. Gamertsfelder had argued that if care was taken to operate only under the best weather conditions, this might not be necessary. The decision, however, was made to filter the exhaust. The filter bank was at the jet-nozzle end of the duct. The system could dispose of 250 pounds of air per second, with expansion possibility for 600 pounds. 80

The stack was made of ordinary concrete, poured and reinforced according to standards issued by the American concrete Institute. Leaving an air space of about six inches next to the stack wall, a layer of firebrick supported by horizontal and vertical carbon steel bars lined the inner face of the stack.

The height of the stack from just below the finished grade to the top was 155 feet. Its interior diameter at "nozzle level," where the duct entered, was 20 feet. The stack gradually tapered to an interior diameter at the top of $151 / 2$ feet. Below grade, the (exterior) diameter at the bottom of the foundation was 33 feet.

Sixteen concrete piles supported the foundation, each extending through the soil and a further distance of at least three feet into the sand and gravel bed beneath. The foundation was shaped like an octagon, each face measuring 13 feet 7 7/8 inches. The octagonal shape continued above ground about 13 feet, 
above the duct opening, whereupon it was round.

A ladder equipped with rails and safety hoops extended up the north side of the stack. About halfway to the top was a sampling port, at which point a working platform was available for the worker. Brackets were mounted near the top of the stack for hanging aircraft warning lights. See HAER Photo Nos. ID-33-E-61, ID-33-E-62, ID-33-E-42, ID-33-E-43.

The stack was finished in the summer of 1955 and taken over by GE, as was the 200-foot high weather tower. 81 GE began preparing for test operations. Workers hauled the engine to the IET (sans reactor) and checked out the turbojets, dolly systems, power and control wiring, and fittings. 82

The IET Control and Equipment Building (TAN-620)

During a nuclear run, the staff was bunkered inside the Control and Equipment building. It contained not only the control room, but the support systems necessary for self-sufficient operations in both normal and emergency conditions. Here were the termini of the personnel tunnel from the locomotive hatch, the periscope tunnels from the scanning heads in the coupling station, and all of the service leads from the HTRE.

The most obvious feature of the building was its invisibility. It was below grade, its roof and walls covered and banked with 14 feet of compacted earth. In the beginning, the contours of the earthwork were crisp and sharp. Ensuing years brought an annual cycle of wind, snow, and blown-in seeds, all of which helped erode the edges and "naturalize" the appearance of the structure. Eventually, the earth shield resembled a somewhat shapeless mound. See HAER Photo Nos. ID-33-E-64, ID-33-E-6.

The control building was 200 feet long on its east-west axis and 50 feet wide. From these dimensions, various projections added to the footprint. The paved road from the A\&M area ramped down (10 degrees) into a shielded driveway on the east end. The driveway was about 400 feet long and ended at an underground turnaround. The building was one story, but included sump pits. The floor, walls, and roof were poured concrete, variously normal, high-density, and boron-treated, depending on the shielding requirement. The floor was 15 feet below grade, and the ceiling height was 13 feet. The exterior walls were two feet thick, treated like all the outer surfaces to prevent the penetration of moisture. The ceiling was three feet thick. The foundation rested on piers.

Within the building, the reactor control functions were on the west end, closest to the coupling station. A double thickness of shielding concrete -- about five feet -- separated this area 
from the service area in the center and east end. The control area was roughly 50 feet square, but chambers projecting to the north included a conference room (capacity: 12 people), counting room, a photographic dark room, a mechanical equipment room, a pump room, and the tunnel leading to the coupling station. Penetrations in the west wall provided viewing access to the periscopes. From the south wall, a tunnel took off for the railroad hatch. Internal walls were made of ordinary pumice block or plywood panels.

A person entering the building from the end of the road at the east end and heading for the control room would enter through an eight-foot-wide shielding door, then walk down a well-lit corridor passing various utility rooms, roughly 20 feet wide each. (Thrust beams in the ceiling rested on piers about 20 feet apart.) The first room on the south side was a diesel room (room 101) containing a diesel generator, fuel leads, and related switch equipment. Sufficient fuel and capacity was available for 15 to 20 days of operation in case the normal electrical system was unavailable to cool reactor water. 83 Next was an electrical equipment room, and then a boiler room. On the north side were pads for additional equipment, sump pits, tanks, and an acid neutralizing pit. Just to the east of the control room were the men's and women's bathrooms. See HAER Photo Nos ID-33-E-63, ID-33-E-64, ID-33-E-39, ID-33-E-12 (turnaround area), ID-33-E-24 and ID-33-E-25 (control room).

Equipment within the building produced bone-conducting noise and vibration. Cork joints surrounding the control room helped to reduce this impact. The building was heated or cooled as needed. other auxiliary systems included compressed air (200 psi for operating the dolly plug; 90 psi for shop air); electricity (a $2000 \mathrm{kva}$ substation transformed power from the A\&M area); heating (boiler); water, both domestic and industrial; air-conditioning at all times for the control room area; auxiliary cooling for compressors, diesels, air conditioning equipment. The wet tower for the cooling system was outside the control room next to the equipment room.

Inside the control room itself, the centerpiece was the control console, a set of cabinets arranged in a semicircular array. From the north and west side of this area ran the personnel tunnel to the coupling station and the periscope tunnels respectively. The personnel tunnel to the railroad hatch left from the south side. This room was the center of remote control operations, including two-way radios and controls that opened the perimeter gate to allow the HTRE rig and locomotive to approach the coupling station. Remote controls could couple and uncouple the HTRE leads and engine tailpipes, open and close the doors of the aluminum building, move the lead shield barrier in 
front of the dolly plug, and operate fire-fighting equipment. 84

The cabinets composing the control console were identical in size and wired as a single unit. Leads to these could be disconnected easily for replacement with a different cabinet needed, perhaps, for a new test. Mindful of the end goal, an airplane under control by a single pilot, a place was reserved at the semicircle for a future cabinet in which all the controls would be operable by one operator. 85

The Exclusion Guard House, TAN-621

The guard house was located at the perimeter fence east of the control building, its function to exclude anyone with no business inside the IET area.

The small flat-roofed building was 26 feet long and 15 feet wide. The spare functional style (sometimes referred to by architectural historians as "industrial vernacular") of the single-story structure was typical of many other non-shielded and non-reinforced buildings elsewhere at TAN. It was made of pumice block walls to a height of ten feet from grade to the top of a coping strip. The foundation and floor were poured with ordinary concrete. At a wall height of 7.5 feet, a 4-foot-wide canopy surrounded the building on north, south, and east sides and shaded a concrete deck beneath. Corner poles supported the canopy, which was made of fiberglass.

Each of these facades also had a hollow-metal door with a wireglass window in the top half. Wireglass windows were installed in all four walls: those on the west elevation were arranged in two triple banks. An aluminum antenna mast for radio communications extended 16.5 feet above the northeast corner. The roof consisted of pre-cast pumice slabs with built-up insulation.

Inside, the major feature of the single room was a U-shaped counter fitted against the west wall and made of plywood with metal trim on the top. A two-way turnstile divided the north and south halves of the room. The plans show no provision for a toilet, any other plumbing, heating, or cooling. ${ }^{86}$ McGarry noted that the guard house was occupied chiefly when non-nuclear activities were taking place at the IET. The operating rules would not have allowed occupancy of this unshielded building during a reactor run.87 Near the west wall was a radio transmitter cabinet. The radio console was part of the counter equipment. See HAER Photo Nos. ID-33-E-66 and ID-33-E-44.

Tank Building, TAN-627

The Tank Building sheltered two large tanks and contained space for smaller tanks and pump equipment. It was 46 feet long and 27 feet wide. Like the guard house, it was flat-roofed, made of pumice block walls bordered on top with a coping strip, and 
had a concrete foundation. The building had no windows. The one door was on the north side. It had wireglass glazing. The roof was made of exposed metal. Notes on the architectural drawing indicated that the building could be extended on either end for future expansion. Inside, the tank vessels each rested on their sides on a pair of concrete braces and anchored into the floor. See HAER Photo No. ID-33-E-68.

\section{Other IET Features}

Other features completed the service requirements for the IET. The electrical substation brought power from the A\&M area. The switch and transformer equipment was erected on a concrete pad, fenced, and not sheltered. Two very large tanks were buried underground. These stored engine and diesel fuel. A drain line carried contaminated liquids from the IET to the A\&M area, which had holding tanks and concentration facilities. See discussion below for TAN-616. Water came from the Admin area. A small chlorination building $($ TAN-626) stood near the sewage treatment area. The sewage line extended from the south wall of the building to a filter bed. For plot plan and utility layout, see HAER Photo No. ID-33-E-56.

Small monitoring stations surrounded the IET at various distances from the coupling station and stack. These enclosures contained dosimetry and radiation detection equipment, where data was collected after each hot run of a HTRE experiment. 88 Aerial photographs taken during the years of testing at the IET show the marks of trails leading into the desert like spokes in a wheel, the hub of which was the coupling station stack. These paths led to monitoring stations positioned beyond the immediate environs of the IET as far away as the NRTS boundary.

The IET was given its first detailed shakedown in the fall and winter of 1955. Workers ran the HTRE-1 assembly -- without the reactor core, which was still under testing at Evendale along with 40 fuel elements -- on chemical fuel. The workers practiced IET procedures as they simulated actual runs with a dummy core and dummy fuel elements: checking instrumentation, filling and draining the core, manipulating control and fuel rods, loading fuel elements into the core. These efforts uncovered defects in electric circuits, missing components, improper connections, and the like. They checked the dolly apparatus: diesel generators, fans, pumps, heat exchangers. They took data on airflow characteristics from the top of the stack.89

On November 4, 1955, the scientists loaded HTRE-1 with 36 fuel elements and brought the reactor -- without the jet engine - to criticality for the first time, a major milestone for any reactor. During the next month, it was brought to criticality 50 times for short runs, typically at low powers of 12 watts or 
less, for further checkouts of fuel and control rod performance and tests of instrumentation.90

The elaborately prepared and long-awaited experiment proving the principle of nuclear flight occurred on December 30, 1955. The wind was blowing in the right direction and at the right speed. The behemoth HTRE-1 rig, anchored to its dolly on the four-rail track, was positioned on its test pad, plugged into the coupling station, and under the control of the team inside the bunkered control room. The operators started the engine on chemical fuel, gradually switched to nuclear operation, and ran the reactor up to 60 watts. The jets expelled the hot exhaust through the ducts and up the stack. This was the first known operation in world history of a high-temperature, gas-turbine engine running on nuclear power. Cheers went up in the control room. After shutting down the reactor and leaving it to cool, the team repaired to a tavern in Mud Lake to celebrate. ${ }^{91}$ In the next weeks, the crews took the reactor up to full power operation.92

When a run was over, the shielded locomotive hauled the HTRE-1 dolly back to the A\&M complex, where A\&M specialists were ready to examine, refuel, maintain, and repair the reactor and engine. During the trip, scattered radiation (secondary effects continuing after the reactor had shut down) continued to be a hazard. People working at $A \& M$ and the nearby Administration area remained indoors until notified it was safe.

\section{The SNAP Program}

The space program aroused the IET for a new mission in the mid-1960s. By that time, the idea of nuclear power had been brought together with another product of World War II: rockets.

Not long after the war, Cold War tensions inspired the U.S. government to consider how it might improve surveillance of the enemy. The U.S. Air Force and the AEC asked the Rand Corporation of Santa Monica, California, to study the possibilities. One issue was how such satellites might obtain operating power in orbit. Industry studies came up with two ideas worth exploring. One was the use of radioisotopes; the other, nuclear fission.93

The U.S. space program began officially in 1955 with the Vanguard satellite program. The first satellites weighed only a few pounds and were powered by solar cells. More power would be needed for heavier satellites. The same year, the AEC began the Systems for Nuclear Auxiliary Power (SNAP) program. Odd numbers were given to power plants using radioisotopic fuel, and even numbers to those powered by nuclear fission.

The experiments that arrived at the NRTS were concerned with SNAP-10A, a "fission battery." The heat of fission generated 
electricity without moving parts. The power output was 500 kilowatts. Before this system was launched into space in 1965, it had to undergo an analysis of the accidents that might occur and how they could be prevented.

What if a satellite in orbit failed and began to reenter the earth's atmosphere? If it fell back to earth or into the ocean, how much radiation would be released? The National Aeronautics and Space Administration (NASA) asked that NRTS conduct some special experiments and to consider what safety features might be built into the space reactors. The early stages of the program at the NRTS began in 1961.94

One goal of the program (among others to determine dynamic and kinetic characteristics of the SNAP 10A reactor) was to demonstrate the consequences of a "maximum credible accident." This called for destroying the reactor in simulated accidents and recording the effects. The issues were explored in three tests that took place at the IET, an ideal facility for them. It was isolated and had a test pad, coupling station, and shielded control room. The shielded locomotive was still running. It could haul dolly-mounted experiments back and forth between the IET and the A\&M labs and shops.95

The investigation of the SNAP 10A involved three reactors. One of them, SNAPTRAN-1, involved research that was accomplished just short of destroying the reactor. After the usual studies and preliminaries, two others met their (intended) ends at the IET.

SNAPTRAN-3 was the first. The accident was to simulate a reactor crashing into the ocean after a fall from space. The test could run only under highly restricted weather conditions, which occurred after several postponements on April 1, 1964. As described by Richard Meservey, an instrumentation engineer, the procedure reused IET facilities -- and ad hoc shielding -- as follows:

They took an old ANP double-wide rail car, put a huge tank on it and filled it with water. The tank had a plexiglass sleeve in the center to exclude water. The reactor was placed in the center of that plexiglass sleeve. When they were ready to run the test, they used explosives to drive the plexiglass sleeve away so water could rush in on the reactor. That simulated crashing into the ocean.

My job was to measure the temperature of the fireball if one should occur. I had a little hoghouse, a triangular structure set up at the ANP coupling station near the test. We had to worry about neutrons coming out and destroying the instruments, so we set up paraffin and cadmium shielding to 
thermalize the neutrons, and lead to stop the gamma radiation. 96

A fireball did develop, but the use of mirrors and shielding around the temperature instruments preserved a record of the heat 
Figure 7. SNAPTRAN 2/10A-1 step impulse drum and drive assembly. Note rotating control drum. Source: INEEL drawing 032-0624-40-706-200077. 
measurements. The test demonstrated that the impact of a crash would cause the reactor to destroy itself, not continue to operate and build up a high inventory of fission products if it fell into the water. See HAER Photo No. ID-33-E-48.

A second reactor was destroyed at the IET on January 11 , 1966. The simulation related to impact on land if a rocket launch had to abort before the satellite had reached orbit. In normal operation, control drums rotated to obtain criticality only after the satellite was safely in orbit. Could impact on earth, even though the reactor had not gone critical, cause the drums to rotate in such a way that the fuel could go critical and begin building up an inventory of fission products? The issue would be of serious concern to anyone recovering the reactor after the crash. Data collected at the IET was aimed to learn how the reactor disassembled itself upon impact.97

An Atlas rocket launched the first SNAP-10A into space on April 3, 1965 from Vandenberg Air Force Base, California. Electricity powered an on-board ion-propulsion unit, telemetry, and a number of small experiments. Waste heat was radiated into space. The reactor functioned successfully for 43 days and was then silent, probably because of a false scram.98

The revival of the IET for SNAP reactors ended its useful mission at the NRTS. The facility was abandoned until it was demolished around 1999. The stack was brought down by explosives and buried where it fell.

\section{PART SEVEN}

\section{THE ASSEMBLY AND MAINTENANCE AREA}

The gateway to the Assembly and Maintenance Area (built by the Utah Construction Company), from the IET was the railroad turntable. Here the locomotive operators, using a system of lights, mirrors, and radio contact with video observers in the A\&M building, turned the HTRE rig toward the east and pushed it down the four-track rail to the gaping doorway of the Hot Shop.

Siting

If the Parsons site surveyors of 1951 had stood on the future location of the turntable and faced east, which they very likely did, they saw in the geological formation before them a useful opportunity. The low shelf of the ancient shoreline trended north/south. The ridge was elevated about 22 feet from the flat "lakebed." This natural earthwork would make a superb shield between hot operations and an administrative area above and farther east. To improve its effectiveness, Parsons 
heightened the ridge another fourteen feet by building a berm on top of it. See HAER Photo Nos. ID-33-E-157, ID-33-E-111, and ID-33-E-156.

Thus, the ridge/berm became the very visible dividing line between the laboratories and craft shops that were the industrial heart of TAN and the more prosaic administrative and personnel service center to its east. The huge Assembly and Maintenance Building, TAN-607, spread out below, its back to the berm and its receiving doors facing the turntable.

Layout

The turntable provides a good viewing position from which to consider the long west facade of building TAN-607 and a few of its auxiliary buildings. The most noticeable feature of TAN-607 is its variable roof line. Each roofed section represented a functional area segregated from its neighbor and defined as "hot," "warm," or "cold." See HAER Photo No. ID-33-E-112 for A\&M building as it looked after its first phase of construction.

The highest section, at the north end, was the Hot Shop. A hot shop, also referred to as a hot cell, hot cave, or hot laboratory, is a shielded chamber in which workers outside the chamber are able to examine and manipulate the highly radioactive materials within. Walls and viewing windows protect them from gamma and neutron radiation. The size of the hot shop depends on the nature of the material to be handled or studied. Likewise the remotely controlled manipulating tools are sized and designed for the expected work.

This high-bay section accommodated the substantial height of a HTRE rig. The door opening was 33 feet high. Inside, the ceiling was nearly twice that high. The shop was deep and wide enough to accommodate two HTRE rigs on their dollies at the same time.99 The extra ceiling height was for the 100-ton crane to lift and move the components of the HTRE assembly. Of the TAN Hot Shop, it was believed -- and often said -- that it was the largest and "most unique hot cell constructed this side of the Iron Curtain," perhaps the world.100 One of the delicate operations performed in this chamber was the removal of spent or "used" fuel elements from the reactor and safe transfer into a "swimming pool" for storage.

The swimming pool projected north of the Hot shop. Its flat low-profile roof indicated no second level. The pool itself was 
Figure 8. General Electric sketch of the A\&M and Admin areas. Top : First phase of A\&M Building's first four sections (three levels): storage pool, Hot Shop, Assembly shop, and craft shops. Bottom: Relationship among A\&M, Admin, and IET areas. Source: APEX-131, p. 6, 16 . 
below grade and 35 feet deep. Here, fuel elements were left to cool (decay radioactively) for awhile before they were packaged into transport casks and sent away from TAN altogether. The water shielded workers above the surface and allowed them to use grapplers and other tools to move the elements to their storage spaces.

Looking to the right (south) of the Hot Shop's high bay, the next section of the A\&M building had a lower roof line. Its large door opened to another set of railroad tracks. This was a "warm" assembly area, where radiation hazard was present, but at comparatively lower levels than in the Hot shop. It was equipped for remote operations if needed. At times, this area served as a decontamination shop.101

The next shift in roof profile indicates the beginning of "cold" regions, where craft workers were free to touch their tools and the materials with which they worked. The section with the lowest roof profile housed small machines and carpentry shops. Towards the south end, (which, as noted previously, were built in a second phase "expansion") the high-ceiling section enclose a large machine shop equipped with jigs, bores, and two overhead cranes, one of which was rated at 125 tons, and a large assembly and laydown area. Finally, the south-most section of the facade was the ANP's major decontamination center, equipped with acid vats and high-pressure steam units, a place designed for the wide range of decontamination problems, nuclear and non-nuclear, that might arise during operations.102

Other A\&M buildings supported the main events at TAN-607. To the north were water-management facilities to demineralize the storage pool water. Contaminated liquids were sent to an evaporator, where water was boiled off (TAN-616). Pumps and piping delivered water from the large supply well located in the Admin area on the other side of the shielding berm

The Actuator Building, TAN-615, was also situated at the northern fringe of the complex. An actuator in a reactor system is the motorized apparatus responsible for moving a control rod into (and out of) the fuel region to regulate the chain reaction. Control rods were crucial components during both normal and emergency operations. Should a fuel element rupture or some other urgent departure from the expected occur, an extremely rapid shutdown would involve thrusting the control rods instantaneously into place -- a "scram" of the reactor.103

One final building completed the original A\&M layout. South and west of the A\&M building and near the edge of the A\&M perimeter fence stood an Engine Test Pad, TAN-609. Sherman McGarry described its purpose: 
...to test the 839 engines with fossil fuel, testing out the engines' modifications before being considered for HTRE operation on the rigs. This building was not unusual except [for] protecting the testing control room for blast effect should an engine fly apart. (Only one engine tested ever did so, in 1957.) 104

As the HTRE tests proceeded, the landscape grew to include various other small buildings and outdoor spaces. Not too long after operations began, for example, it became evident that fuel transport casks, bulky radioactive equipment, and parts needed to be stored somewhere. A shelter was needed for dollies not in use. GE created a fenced outdoor yard for such storage northwest of TAN-607 and called it the Radioactive Parts Security storage Area (RPSSA). Two buildings (TAN-647 and TAN-648) were part of this complex.

The Assembly and Maintenance Building, TAN 607

The philosophy guiding the design and construction of the A\&M complex was precisely opposite to that employed at the IET. Here, the shielding budget was spent to surround the radioactive sources, not the workers. The guiding principles for the architecture and engineering of this building were dominated by safety and shielding considerations.

The A\&M building was a long row of rooms, their industrial doorways all on the west side, but their interior dividing walls of varying construction materials and thickness. Excavation depths, wall thickness, siding, the number of stories, and ceiling heights all were dictated by the special function of the work space -- and by the expected presence or absence of radioactivity. Inside, this made for interesting doors and passages from one section to another in order to keep cold areas from becoming contaminated with radioactivity.

Parsons produced the first drawings for the north half of the building in 1953 -- the Storage Pool, Hot Shop, Warm Shop, Locomotive Pit, Special Services Cubicle, Special Equipment Service room, Mechanical Shop, and Carpentry Shop. Drawings for the "expansion" were ready in August 1956 and added more shop specialty areas. From the north wall of the storage pool to the south wall of the Decontamination shop, the building was about 500 feet long. See HAER Photo No. ID-33-E-167.

Hot Shop. The Hot Shop was 160 feet long (east/west axis), 52 feet wide, and 60 feet high. The side walls were made of reinforced concrete 6 feet, 10 inches thick at the base. The top 18' 8" of the side walls tapered to two feet thick at the roof. The front wall was 5 feet thick and also tapered to a width of 2 feet at the top. The rear wall of the Hot Shop was 5 feet thick 
up to the level of the bi-parting doors opening the special Services room and then 4 feet beyond. Tapering the walls saved expense, for no workers could potentially be exposed at certain upper levels. The roof itself was made of ordinary concrete and 60 feet above grade level. It was two feet thick and supported by reinforced concrete beams across the width of the Hot shop. See HAER Photo No. ID-33-E-165, section C. The foundation was thickest under the bi-parting doors, less thick under the west side of the Hot Shop floor, and then the least thick from there to the east wall. Structural piers ranged in diameter between 16 and 60 inches.105 The four-rail track from the turntable entered the Hot Shop set into the reinforced concrete floor. HAER Photo Nos. ID-33-E-158, ID-33-E-159 See HAER Photo No. 169 for shield wall details.

On both sides of the Hot Shop were three operating levels. The Hot Shop chamber itself was a clear space all the way to the ceiling. It allowed the 100-ton crane 49 feet of clearance under its hook. A tunnel level below grade provided access to the two turntables set into the Hot shop floor.

The imposing doors of the west entrance admitted the HTRE rigs after a run at the IET. The motorized "bi-parting" doors were heavily shielded and made of high-density concrete. In their open position, each half slid into a pocket in front of the building wall sided with corrugated metal. Installing these doors had been a major milestone during the construction of the building, as they had been fabricated at the site. The clear opening was 28 feet wide by 33 feet high.106 
Figure 9. Inside the Hot Shop, facing the bi-parting doors (in closed position). Dolly and turntable at right hold apparatus under investigation. Note pool vestibule at lower right. Source: INEEL Photo 63-1968. 
Once inside the Hot Shop, the component parts of the HTRE could be disassembled, inspected, repaired, and reassembled. Either of two cranes, the 100-ton or the 30-ton, lifted the object to one of the turntables, each remotely operated and able to bear a weight of 50 tons. One was north of the tracks; the other, south. Each was 16 feet in diameter. Together with a device called an "upending jig," they made it possible for workers to see an object from any position. The base for this jig was located a few feet from the end of the four-rail track.

Another device from above helped workers manipulate whatever had been lifted into place. Just under the cranes, recalled Sherman McGarry:

... was an Overhead Manipulator ("O-man"), on its own rails (each side of shop) that could traverse the length of the shop. The O-man was designed and constructed by GE.It was one large manipulator arm that could be controlled to grasp a raw egg without breaking it or to clasp [items] up to 1 $1 / 2$ tons without losing them, ie, very versatile....The o-man had a 360-degree-head horizontal maneuver with the

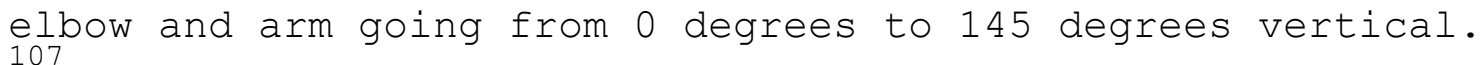

In its weakest position the O-man could exert a force of 400 pounds in any direction, or a 400-pound torque. It had a repertoire of ten different motions in response to operator commands.108 Along the walls, two other manipulators, also made by GE, were affixed on rails that ran the entire length of the wall at a height of 37 feet above the floor. These provided a reach from the top of the shop down to floor level and could maneuver 180 degrees from side to side.109 Operators could use one or all of the manipulators singly or in groups to perform exacting operations.110

Utilities and tools such as pneumatic wrenches, drivers, hammers, electric power, air, water, gas were available inside the Hot shop. The plugs and pipes for these installations penetrated the shield wall. Therefore, the pipes were Z-shaped, making two bends through the six feet of concrete. The plugs were stepped, with the narrowest step on the Hot shop side.111

operators adjusted flow rates and connected or disconnected these services by remote control. All service lines had spares. Extra conduit was in place for future expansion.

In the event that a crane or the O-man needed to be serviced while a radioactive source was in the Hot Shop, a Special Equipment Service Room (SES) was located on the second floor east of the thick shielding wall. This room was 51 feet wide and 30 feet deep. Its ceiling extended through the third level. A 
bi-parting shielding door opened to allow the crane and the O-man to enter the room from the Hot Shop. The O-man rails were moved out of the way when the doors opened.112

At times, it was useful to remove a component from the rig in the Hot Shop, isolate it, and take a closer look than was feasible in the vast space of the Hot Shop. Therefore, a smaller hot cell provided for this. It was on the first floor level and projected from the Hot Shop's south wall at its east end. Known as the Inspection Cubicle (also Special Services Cubicle), the room was 35 feet long (north to south) and 10 feet wide. The ceiling was 17 feet high, and the shield walls consisted of high-density concrete four feet thick. The interior of the cell was lined with 16-gauge stainless steel sheet metal, a surface easily cleaned and decontaminated.113

Along its walls were six shielded viewing windows, six feet thick. Objects were transferred from the Hot shop into this cell by means of a special plug-type door connecting the two chambers. The thick door rolled along the floor and could slide back to make an opening 4 feet wide and 13 feet high. The plug was stepped, exhibiting another design aimed at preventing gamma and neutron radiation from streaming through such penetrations in shield walls. See HAER photo No. ID-33-E-159, below and slightly to the right of the storage pool vestibule.

The Inspection Cubicle was equipped with its own set of manipulators: two bridge-mounted overhead and a pair of Argonne Master Slave fixtures. Appropriate to the more delicate work done here, tools included sectioning devices, scales, and a periscope equipped with a camera. Like the larger Hot shop, this cell had its own service lines for power, water, deionized water, air, and vacuum. All fixtures worked by remote control -- as did the decontamination lines. Drains (appropriately shielded) carried waste to appropriate holding tanks. Pipes and plugs were z-shaped and stepped, respectively.114

A control gallery was an accessory of any hot cell, regardless of its size. The "master" controls to the "slaves" within were in the hands of operators standing before one of the shielded viewing windows set into the wall. These were located on the second floor along the south and north sides of the Hot shop (and along the east and west sides of the Inspection cubicle.) Below each window was an operating console for controlling any of the manipulators. The operator also could adjust the light levels provided by four sets of fluorescent lights that ran the length of the ceiling.115 Microphones in the cells transmitted sounds to the operator; operators at different windows could communicate with one another.116 See HAER Photo Nos. ID-33-E-115, ID-33-E-119, ID-33-E-120, ID-33-E-123, ID-33-E-124 . 
McGarry described the Hot shop windows as being...

... unique in construction. [The combination of leaded glass and zinc-bromide to fill the void between the glass]

afforded seven feet of shield protection... [For safety, no two control panels] could be operated simultaneously -- only one could control; the rest were automatically locked out of operation by an interlock system. This feature was designed so no two movements could be made to bring... fissionable materials together inadvertently. The [viewer] could see the length of the shop from 15 degrees vertical and to the floor or the ceiling. Each balcony floor was 35 feet above the hot shop floor, making an operator's head approx 41 feet from floor level.117

Zinc bromide had the same index of refraction as the leaded glass. Despite its thickness, a window gave a clear view without distortion. The Hot shop was so large that a pair of binoculars was a typical accessory near the control panel. Seven windows were built, with spaces provided should others to be added later.

It was possible for workers to enter the Hot shop (when the bi-parting doors were closed) either during an emergency or when radioactivity levels permitted. The door was on the south side on the west end. To prevent radiation from streaming into the area, the architects designed a maze, or labyrinth. The maze consisted of five 90-degree corners. The walls were 8.7 feet thick and made of ordinary concrete. Exiting the maze, a person was monitored for radioactive contamination. From here, he could either enter the equipment gallery (below the operating gallery) on his way to the stairs or go to the change room and don special shoes or other special clothing stored in a personal locker. See HAER Photo No. ID-33-E-158, first floor plan, room 114.

Two other essential accessories to a hot cell include an instrument room and a counting room. The Hot shop's were adjacent to the south operating gallery. The counting room was the special province of health physicists (HPs), whose business was to protect workers from radiation. The HPs sampled surfaces of floors, desks, doorknobs, and walls for contamination. They analyzed dosimeter badges and radiation monitor samples, among other duties. Their counting room was required to be as free of background radiation as possible. Thus, it was surrounded by three feet of ordinary concrete shielding and vented for positive air pressure.

The instrument room was next to the counting room. This was, in fact, a small laboratory, in which instrumentation engineers designed and fabricated the thermocouples and other instruments that were fitted onto the HTRE rig and dollies to detect and 
record temperature, pressure, conductivity, and other parameters.

The third level of the Hot shop provided access to platforms and two control rooms for the cranes, one each on the north and south side. Each was provided a shielded viewing window into the Hot Shop. HAER Photo No. ID-33-E-158 floor plans illustrate the three levels of the Hot shop.

Bulk Shielding Storage Pool. The main part of the pool was a rectangle 70 feet long (east/west axis) and 48 feet wide. A smaller part called the "vestibule" projected under the Hot shop shielding wall and into the Hot shop to form another rectangle. This portion was 35 feet long and 24 feet wide. The pool was filled with water 24 feet deep. The shielding wall between the pool and vestibule extended below the pool's water level five feet, leaving an opening of 19 feet through which the (underwater) dolly and its load could travel along a two-rail track laid into the floor.118 see HAER Photo No. ID-33-E-174.

The Hot Shop's 100-ton crane lifted fuel elements or other components onto the underwater dolly while it was positioned in the vestibule. The loaded dolly was pulled under the shield wall by a 15-ton crane that was bridge-mounted above the pool and equipped with a telescoping boom. Once into the main part of pool, the dolly was parked for unloading. The east and west walls (the long sides) of the pool had shelves for storing light-weight objects. Underwater lighting in the pool walls assisted operators do their precision work.119 See HAER Photo No. ID-33-E-125 for a view of the storage pool and bridge crane.

At the far north end of the pool, a doorway led to a transfer area, where items could be (remotely) lifted from the pool and deposited into shipping casks. Spent fuel went to the Chemical Processing Plant about 20 miles south on Lincoln Boulevard, where it was dissolved and reprocessed to recover the unfissioned uranium still present in the fuel. Other items might be delivered to the RPSSA or to the NRTS Burial Ground at the southwest corner of the NRTS site.

The depth of the pool water shielded workers above the pool from gamma and neutron radiation, the hydrogen in the water absorbing its energy. The water was stripped of its natural salts and mineral content to avoid creating radioactive ions of these elements. Depending on the (radio)activity of the items in the pool at any given time, the water collected heat and required circulation and cooling. The exterior walls and roof of the pool were made of ordinary concrete. Personnel access to the Hot Shop next door was via a ramp to a second-floor corridor along the east shielding wall end of the Hot shop.

Warm Service Area. South of the monitoring room, a wall 
divided the Hot Shop section of the building from the Warm Service Area. A set of four rails entered the (non-shielded) doorway. This area, while it had a high ceiling, was not as long as the Hot Shop, being only 81 feet long and about 45 feet wide. Beyond the wall at the east end of the shop were various labs and offices.

The floor contained a pit for servicing and maintaining the shielded locomotive pit. The locomotive weighed 210 tons. It had two 350-horsepower diesel-electric motors, enough to push the HTRE rig and dolly up the 1 percent grade to the IET.120

The architectural features of the Warm (and Cold) Service Area were less interesting than the Hot shop from a shielding point of view. Spaces were provided for offices, stairways, corridors, locker rooms, bathrooms, conference areas, equipment and fan rooms, janitor closets, and the like. A "special source" vault was in this area, the receiving area for radioactive materials used to calibrate instruments.

Cold Assembly. The A\&M facility was equipped with a variety of specialized laboratories. The Chemical Lab (second floor) was equipped to analyze samples, certify materials, and study such problems as turbidity which occasionally appeared in viewing glass fluid. It had a balance room and an emergency shower. The Metallurgical Lab (next to the Chem Lab, second floor) had a mobile X-ray unit for inspecting welds (first floor), a plating room, a darkroom for developing X-ray film, a tensile testing machine, and radiograph-making equipment for producing weld reports. The Photographic Lab (first floor) handled standard black/white film and motion pictures. A Radiographic Materials Lab included an Elox block cutter with a remotely operated balance, a periscope/camera outfit for making remote images, sample cutters and mounting equipment. This lab was ventilated for negative air pressure, air filtered with disposable filters. 121 For first floor plan, see HAER Photo No. ID-33-E-160; for second floor plan, HAER Photo No. ID-33-E-161.

Shops. The Engine Maintenance and Large Machine Shops, rooms 140 and 149 respectively, were 45 feet high to allow for an I-beam trolley bridge, the bottom of which was 28' 4" from the floor. The welding shop was slightly higher than its northern neighbor, at 46 feet high. It contained a storage balcony for jigs and fixtures. On the main floor, a two-ton crane rolled from north to south.

High Bay Assembly Shop. This section (room 158) was 64' 10" high, providing ceiling space for a 25-ton bridge crane and its auxiliary 5-ton hook. Its sliding door (no. 142) rolled across the facade, projecting 14 inches from it, and was covered with an 
aluminum weather hood.

Chemical Cleaning (Decontamination) Room. At the south end of TAN-607 was the final section of the building. Its walls were made of poured, reinforced (ordinary) concrete about 1.5 feet thick. The room was 39' 3" high and about 32 feet wide and equipped with a 10-ton bridge crane. Acid and neutralizer pits contained fluids used in cleaning operations. Radioactively contaminated liquid wastes entered an underground drain leading across the front of TAN-607 to TAN-616, the Hot Liquid Waste building. See HAER Photo Nos. ID-33-E-127, ID-33-E-128, ID-33-E-129, ID-33-E-130.

The Jet Engine Test Building, TAN-609

GE engineers needed a place to check out the test engines before they were ever subject to test with a reactor. These were not engines with established performance records, but modified experimental models.

The building was in two parts. The test engine was hauled into the prefabricated metal part of the building, which had roll-up doors at the east and west ends. The operator sat in the pumice block control building on the north side. He operated a control console and could look in on the jet pad through a viewing window. Just outside the building was an above-ground tank, probably containing a supply of fire-suppression water. See HAER Photo No ID-33-E-133.

The Actuator Building, TAN-615

The Actuator Building, located north of the A\&M building near the old lake shoreline, was the place devoted to testing prototype actuator mechanisms, the motors, instruments, electromagnets and other devices that moved control rods in and out of the HTRE reactors. The operational goal was 100 percent reliability. Nothing less would assure the safety of the crew in an airplane. Actuator tests were called "cycles," representing a sequence of insert and withdraw. Scientists conducted around 5000 such cycles in their quest for fail-safe hardware.122

General Electric designed the Actuator Building in November 1956 and built it soon after. It was a standard prefabricated steel frame building sided with corrugated metal and covered with a gable roof, also of metal. The floor was a concrete slab fourinches thick. Most of the building was 20 feet high from grade to the roof eave, although a low-bay section on the north 
Figure 10. Test Area in Actuator Building, TAN-615. Lockers against wall stored actuator mechanisms, long assemblies that drove control rods into the reactor region containing fuel. Source: INEEL Photo PN02-062-01, frame 6. 
side was 10 feet high. Personnel doors gave access to each section from the east and west sides. The entire building was 40 feet wide and about 67' 4" long. The low-bay section was 24 feet long. See HAER Photo No. ID-33-E-184.

The low-bay section contained a toilet, decontamination (decon) change room, clean change room, and a clean room. A gypsum-board wall separated the low-bay from the high-bay area. The high-bay area was divided in half by a full-height metal partition down the center under the roof ridge. The west side was called the "decontamination area," while the east side was called the "test area." Each side had a floor pit and sump. The pits, each 14 feet long (north/south axis) by 8 feet wide and 8 feet deep, were at the south end of the high-bay section near the centerline. The reinforced concrete partition between the pits was 8 inches thick. A metal grate covered each pit.

Access to the test area from the low-bay clean-room area was via an open arch. The room was equipped with work tables, two control consoles, two test stands, an electronic table, and a row of tall, narrow upright lockers. The lockers stored actuator assemblies up to 20 feet long. The decon area contained three decon tanks, a sink, pump, fume hood, and exhaust stack.123

In the 1970s, the Loss of Fluid Test program appropriated the building and renamed it the TAN Fuel Handling Facility. The old "decontamination area" was dismantled by removing the metal partition in the center. An I-beam trolley crane was installed beneath the roof ridge. In 1973, the building was enlarged at the north end with an addition of 1468 square feet, also prefabricated metal, but with an eave height of 35 feet. The addition contained another pit and new aluminum fuel module storage lockers.124

In 1976 the (southwest) pit in the former "decontamination area" was filled with gravel and capped with a concrete slab. The mission continued to involve the testing of actuator mechanisms, this time for the Loss of Fluid Test reactor. Other modifications involved supplying the building with steam, condensate, demineralized water, and air via piping from TAN-616 next door. Penetrations entered TAN-615 in its south wall. An assortment of pipes connected the two buildings. A drain and pump sent waste water to the $\mathrm{V}-3$ tank next to TAN-616.

After the Loss of Fluid Test program ended, TAN-615 became a general maintenance shop and was renamed Maintenance Building. It was abandoned in 2001 and has been demolished.125

Hot Liquid Waste Treatment Plant, TAN-616

The strategy for dealing with radionuclide-contaminated 
liquids that accumulated due to HTRE operations, decontamination activities, accidents, and other processes was to isolate, treat, and concentrate them in a storage tank. To this end, a complex system of waste drains, pumps, holding tanks, and piping connected the A\&M labs, hot shops and cells, and decontamination shop to the TAN-616 plant. Waste drains came from the IET, the Actuator Building (TAN-615), and the Water Filtration Building $(\mathrm{TAN}-649)$.

The system involved various treatments for the waste (acid and caustic) and an evaporator to drive off water. Initially the system had three holding tanks ( $V-1, V-2$, and $V-3$ ), but another $(V-9)$ was added later. The first three tanks were buried underground on the west side of the plant building. These held wastes being delivered for treatment and concentration.

The building itself, most of which was one story above grade, was built of concrete, the thickness of any given section depending on its particular function and shielding need. When looking at the floor plan, the footprint of the building shows three sections of unequal length, giving the west side a stepped appearance. Were the building a complete rectangle, it would be 46 feet long (east/west axis) and 36 feet wide. See HAER Photo Nos. ID-33-E-185, ID-33-E-149, and ID-33-E-150.

The most heavily shielded section was the room containing the evaporator pit, with walls 3 feet to 2 feet thick. The floor of this room was in the basement. The ceiling was the building roof 15 feet above grade. Other sections, walled with lesser widths of concrete, functioned as an operating pump room, pump room, caustic pump room, control room, and entry vestibule. The control room, vestibule, and caustic pump room had no basement. The flat roof over these areas was 12 feet above grade. A "penthouse" above the caustic pump room contained heating and ventilation equipment. This area was easily identified by its gable roof. 126

The large evaporator vessel was the central feature of the concentration process. Beginning in 1958, sludge from the bottom of the vessel was periodically removed to tanks located southwest of TAN-607 in a field on the south side of Snake Avenue, an access road.127 The guard house controlling entry to this area can be seen in HAER Photo Nos ID-33-E-88 through ID-33-E-96.

After years of operation, the vessel cracked from stress corrosion. The contents leaked onto the floor of the pit. The vessel was removed and repaired, but eventually cracked once more. Again, leaks ended up on the floor of the pit. The facility was shut down in 1970, but waste in the process system at the time remained where it was. A new system, called the PM-2A, was 
installed, but operating difficulties shut it down in 1975. Again, untreated waste remained in process lines. Sometime after 1983, the roof and access hatches began to leak. Standing water inside may have found pathways for contamination to migrate outside the building. A new roof was placed over the building in 1993.128

TAN-616 was one of the DOE's cleanup targets as this report was being written.129 Radioactive contamination inside its chambers prohibited the HAER photographer access inside the building. A large area outside was cordoned off for clean-up of the soils and drains around the building and near the buried tanks. This area was also off limits to the photographer. The list of metals, radionuclides, and solvents in the tanks and as contaminants elsewhere, is a remarkable postscript to the intensely industrial character of the ANP project: barium, cadmium, chromium, lead, mercury, silver, acetone, trichloroethylene, carbon tetrachloride, Cesium-137, cobalt-60, Strontium-90, and assorted isotopes of uranium and plutonium, among many others.130

Hot Cell Addition, TAN-633

This addition to the hot cell capabilities near TAN-607 was uniquely situated to examine fuel elements or other items that had cooled in the storage pool. They could be diverted to this building and examined before being sent away for reprocessing at the NRTS Chemical Processing Plant. Among its special tools was an electron microscope.

The building was tucked between the Actuator Building, TAN-615, and the Water Filter Building, TAN-608, all under the shadow of the ridge formation and shield berm on the east. It was 50 feet wide by 91' 4" long (north/south axis), and 16' 8.5" high. The Hot Cell Addition was connected to the pool building by a neck (referred to as a "vestibule" on the architectural drawings) about 15 feet long and 26 feet wide. Inside, the eastern portion of the neck was taken up with a corridor 7' 8" wide and about 40 feet long. This corridor connected the pool building to the cell region of the new addition. Both the main building and its neck were flat-roofed and made of pumice block walls. The roof had metal decking and built-up roofing with double-gravel surface. See HAER Photo Nos. ID-33-E-176, ID-33-E-177 through ID-33-E-179.

Construction required the re-routing of buried water and sewer lines to new locations, re-locating of fire hydrants, and relocating of steam and air lines. The road and a street-washing apparatus that had provided truck access to the storage was relocated north. See HAER Photo No. ID-33-E-177. 
Within the building, the block of four hot cells was 12 feet wide and 40 feet long and surrounded on all sides by high-density concrete. The roof and floor were made of ordinary concrete. On the east side, the plans show, step-shaped doors swung open to receive the fuel container. These were not built. However, an opening did allow for the insertion of study materials into the cell.131 Shielded viewing windows were on the west wall. Workers stood in the operating corridor just west of the windows and manipulated the contents of the cell by remote control. Each cell was 6 feet wide, 8 feet long, and 14 feet high.

Each hot cell was equipped with a unique selection of work tables, manipulators, and other equipment. Penetrations through the concrete for control lines and service exhibited Z-shapes. All had air exhausts, floor drains, and a small "lost tool opening" on the east side. See HAER Photo No. ID-33-E-179.

Fuel caskets moved by remote control in a straight line from the pool building, down the corridor, and into the Addition. They traveled on a 5-ton monorail as far as the designated cell. After the hot cell analysis had been completed, the item was returned to its transport cask and sent back into the monorail corridor. Here the cask could return toward the pool for restorage or out a west-side exit to a waiting transport truck. Alternatively, the cask could move northward and out the north door of the building. Here a concrete pad, sheltered by a gabled canopy with a corrugated tin roof, allowed for a transport truck to pick up the cask at this location.

Work spaces within the building included a change room, a set-up area, and tool decontamination area. After the ANP program had been canceled, the room in the northwest corner was converted to a photographic darkroom. The mechanical equipment room was in the southwest corner. An enlargement was planned for the east side another 28 feet, but this was not built.

Demineralization Plant, TAN-656

Built along the north wall of the Hot Shop, this building made use of space between the water filtration building, TAN-608, and the north wall of the storage pool. Its north and south walls touched these buildings respectively. The space so created was 11 feet wide and 20 feet long (east/west axis). Water draining from the plant went via buried pipe to a manhole west of the Hot Cell Addition.

The plant demineralized the water in the storage pool. It was divided into two rooms. The "pool water purification room" was to the east and surrounded by walls of ordinary concrete 1.5 feet thick. The west side, enclosed by a wall 1 foot thick, was the personnel passageway between the pool building and TAN-608. 
The building had a flat roof with built-up roofing. It had no exterior doors. See HAER Photo No. ID-33-E-180.132

Radioactive Parts Security Storage Area, TAN-647, and TAN-648

By the end of 1958, the pace of ANP activity demanded an expansion of utilitarian space for storage of large and bulky items such as dollies and transport casks while not in use. Having been exposed to operations or materials that made them radioactive, they needed to be secured and out of the way. GE found space for the Radioactive Parts Security storage Area adjacent to and on the west side of the IET tracks. The southern edge bordered an acid pond. See HAER Photo No. ID-33-E-182.

Access was available either by road or by rail, depending on the item being stored. Dollies went via rail on a new set of tracks leading from the turntable directly into TAN-647, named the Dolly storage Building. Access by road was from an existing road leading to the north end of the A\&M Building. Items could be stored inside Storage Building, TAN-648, or set outdoors. An area southwest of TAN-647 was designated for transport cask liners. This area lay between the new set of tracks and the tracks leading to the TAN-609 area.

Fencing around the storage area consisted of a 7-foot-high close-grid zinc wire fence topped with three strands of galvanized barbed wire, for a total height of 8 feet. Warning signs informed potential visitors of the radioactive hazard.

The Dolly Storage Building, TAN-647, had framing of prefabricated structural steel with siding and gable roof of ribbed galvanized steel (vertical ribbing). The sides of the buildings had ribbed plastic light panels installed all along the length. The building had a concrete floor reinforced sufficiently to hold the weight of a loaded dolly. Four-rail track was laid into the floor. The building was 36 feet wide and 145' 10" long (north/south axis). Each of the gable ends had large metal rollup door opening a space 28 feet wide by 34 feet high. See HAER Photo No. ID-33-E-139.

The Parts Storage Building, TAN-648, was of the same design as TAN-647, but with different dimensions and only one rollup door on the north end. It had the same type of framing, roof, plastic light panels, and siding as TAN-647. The rectangular floor was 70 feet wide by 97'10" long (north/south axis).133

Cask liners were cylindrical steel containers used to transport highly radioactive spent reactor fuel or other material (such as debris from Three Mile Island). For storage at RPSSA, the liners were placed within concrete shrouds three feet thick. The outer foot was made of high-density concrete. Cooling ducts 
ran through the concrete. These were equipped for the monitoring and removal of heat resulting from radioactive decay. Each structure was a total of 12' 4" in diameter and 16' 2" high. Cranes lifted the liners into and out of the concrete casks. Steel covers fit over the top. See HAER No. ID-33-E-183; and HAER Nos. ID-33-E-139 through ID-33-E-141.

The Outdoor Turntable

Once GE engineers knew the dimensions of the dimensions of the HTRE-hauling dolly and the locomotive, they could design the turntable. It had to accommodate their combined length. The fit was achieved with a turntable diameter of 84 feet. Including the perimeter foundation, the structure was 90 feet in diameter. Stubbed rail projections from the perimeter allowed for maneuvers in which the locomotive shifted from a "pull" position to a "push" position. From the turntable, destinations included the IET, the Hot Shop, the Warm Shop, the Engine Test Pad, and later, the Hangar building. See HAER Photo No. ID-33-E-111, an aerial view.

Of all the complex structures at TAN, the turntable and its radiating tracks are among the simplest for a visitor to understand and appreciate. Parsons engineers, however, who recall the days when construction was underway remember the job as exceedingly complex and exacting. Maintaining the proper ballast and distances between each of the four rails was a challenge. Derailment, especially if it occurred with a load returning from a nuclear run at the IET, would have been a very serious emergency.134

Construction photos show the steps taken to build the turntable: excavation, formation of piers, laying of the radial and perimeter foundation rails, filling the space between beams with gravel, and laying of the wooded deck with its many rails. The electric motor was operated by remote control. HAER photographs show a few steps in its deconstruction and demolition. See HAER Photo Nos. ID-33-E-142 through ID-33-E-146 for construction views, and ID-33-E-77 through ID-33-E-87 for demolition views.

Modifications to A\&M Facilities after 1961

A number of new buildings, typically metal prefabricated rectangular structures of various sizes, appeared on the A\&M side of the of the earth embankment from time to time after 1961. These functioned typically as warehouses, shops, or shelters for monitoring stations. A wooden shack sheltered certain turntable controls, for example. See HAER Photo nos. ID-33-E-78 and ID-33-E-79. Additionally, new programs and projects called for the interior modification of existing ANP structures. 
PREPP. The Ralph M. Parsons Company returned for a major redesign of part of TAN-607 in 1983-84. At this time, DOE was considering how best to retrieve from the old NRTS Burial Ground solid transuranic (largely plutonium) waste that had originated at Rocky Flats in Colorado. (The Burial Ground had in the meantime been re-named the Radioactive Waste Management Complex, or RWMC.) DOE's objective was to retrieve this waste and repack it for shipment and permanent disposal at the Waste Isolation Pilot Plant (WIPP) in New Mexico. A number of steps were involved in executing this plan: safely retrieving storage barrels, identifying their contents, and processing them for efficient shipment to New Mexico. The WIPP facility had certain criteria that any shipment into its facility had to meet before it would be accepted. As retrieved from the RWMC, the waste drums did not meet the acceptance criteria. Further processing would be necessary.

To demonstrate possible approaches to these problems, DOE established a Process Experimental Pilot Plant (PREPP). The PREPP plant took over the then-vacant room within TAN-607 known as the North Machine Bay. (The shop just south of it was the high-bay machine shop. These shops were roughly in the middle of the row of TAN-607 shops.135) The space was cleared out and replaced with a virtual multi-level building within TAN-607. Its internal steel walls, concrete floors, and air locks separated the various chambers enclosing equipment such as shredders, a rotary kiln incinerator, and compactors. Off-gases from incineration were further subjected to treatment, and there was a place for large banks of air filters. The PREPP plant capacity was to be ten tons of waste a day.136 See HAER Photo No. ID-33-E-175, the only PREPP drawing included in this report, as an example of the re-use of TAN-607. The exterior of TAN-607 was not affected by the remodel.

The PREPP facility went under construction in 1983 and was completed in 1986. The operators launched a check-out and evaluation phase to identify characteristics, faults, and safety deficiencies, if any, in the process designs. They used non-plutonium wastes for these shakedown tests. Indeed, the preliminaries did reveal that the facility needed modification. Meanwhile, national criteria and standards for the management of transuranic materials were changing, leaving the PREPP facility out-of-compliance. In the face of several uncertainties about the future status of WIPP, the criteria, and the ability of PREPP to qualify under new requirements for plutonium-handling facilities, DOE deactivated PREPP beginning in 1990.137

Other Modifications. A\&M facilities were adapted for other programs that came after the ANP project. The Loss of Fluid Test program was one of the more important of these (and is discussed below). The floor of TAN-607's Decontamination room was raised a 
few inches with a new layer of rebar and concrete. In 1987, during the period when TAN-607's Hot Shop was receiving Three Mile Island shipments, workers tired of having to clean the trucks before they entered the Hot shop during wet, icy, windy weather. A metal structure was attached to the front of the building, hiding the Hot Shop's big bi-parting front doors. But the "truck breezeway" greatly simplified the necessary truck cleaning operations.

As the $1990 \mathrm{~s}$ passed into the new century, the number of new missions for the A\&M buildings declined. Other areas at the INEEL took over functions that had occupied TAN-607. INTEC took possession of the Three Mile Island fuel, for example. The shops equipped for heavy industry had little new industry to serve. DOE decided to clean up the area and demolish many A\&M buildings.

\section{PART EIGHT}

\section{THE ADMINISTRATIVE AREA}

The Administrative Area consisted of offices, non-nuclear laboratories, warehouses, water supply wells and storage tanks, warehouses, and personnel services such as a cafeteria, change house, and dispensary. As "cold" activities, they required appropriate separation from the A\&M.

\section{Siting}

Because the "shoreline" ridge and berm afforded protection from radiation, the Administrative Area was located on its east side, but within walking distance to the A\&M complex. However, nuclear analysts warned that, because of the possibility of scattered radiation, personnel should remain indoors whenever the hot HTRE rig was being transported from IET to the Hot shop.

\section{Layout}

The Admin Area was the destination of road access from Lincoln Boulevard and points south at NRTS. Workers, visitors, and bus drivers parked their vehicles in a parking lot on the east side of the security fence. They entered the area by passing through a guard house.

The guard house was attached to the Administration Building, TAN-602, directly to the north. The long low-profile Admin building received morning sun on its long east side and the afternoon sun on the west. Continuing west, another tier of facilities included two large water tanks and their pumping equipment, a warehouse, and a maintenance building providing automotive and other shop services. As the ANP program grew, other buildings were added: TAN-649, water filtration building; 
and TAN-628, a second warehouse.

The boundary of the Admin Area was delineated by a security fence, which also divided it from the A\&M complex. Pedestrian access to A\&M was available at only one point, the Change House. This building functioned like the narrow middle of an hourglass. In the early days of the ANP program, all traffic, including vehicular, between the A\&M complex and the Admin area flowed through this narrow passage. (Later, roadway access to the A\&M went around the berm on both the north and south ends.) Radiation detectors scanned bodies and feet for contamination; guards checked badges for appropriate authority to enter. Showers and lockers were provided. Vehicles could drive through a cut in the ridge to arrive at the east end of the A\&M complex. The pedestrians path offered a more direct route. See HAER Photo No. ID-33-E-225.

The aquifer upon which the entire ANP site rested flowed from a direction generally north to south. The water supply wells therefore were upstream of all the operations, which in turn dictated that the sewage treatment facility be downstream. The plant served both Admin and A\&M, so it was located southwest of the A\&M building. The electrical substation was south of the guard house and away from other activity.

Administration Building, TAN-602

This building set the design motif for all of the non-nuclear buildings at ANP. Its building material was cheap, easy to get, easy to erect, and required minimal exterior maintenance: pumice block. With few exceptions, buildings were rectangular, their dimensions governed strictly by the immediate needs of the space, albeit with expansion possibilities often noted on plans. All floor foundations were concrete. Most roofs were flat. Personnel doors were of standard sizes, typically hollow metal unless a guard station door needed glazing. The Administration building contained offices, so it had windows, but windows were relatively rare elsewhere at the ANP. Aesthetic considerations made no appearance, unless one grants this function to the coping or bonding strip parallel to the roof line of most buildings, which was sometimes painted a dark color contrasting with the pumice block.

The Administration building was one of the first ANP drawings to come out of the Parsons workrooms, appearing in December 1952. Not long thereafter, it was also one of the first to be "expanded." Its interior spaces were modified frequently. One of the first remodels supplied a Quality Control Laboratory, for example.

The building was oriented with its very long axis 
north/south. Inside, a row of similarly sized offices lay on the east side of the building, each with a window. Spaces on the west side of the corridor included other offices and specialty areas such as a vault, mechanical equipment room, and storage areas. Soon after construction, parts of the west side were converted for laboratory use. The first drawings of the building show it as 50 feet wide by 224 feet long. See HAER Photo Nos. ID-33-E-220 and ID-33-E-221. It grew in length and also developed a parallel 
Figure 11. Admin Building and Guard House, 2003. Top: Approach to Guard House from Parking area; east facade of Admin Building. Bottom: South end of Admin Building and detail of windows. Source : INEEL Photos HD-34-1 and HD-34-2. 
Figure 12. Admin Building and Guard House, 2003. Top: Interior courtyard. Bottom: Guard office within Admin building; sleeping area. Source: INEEL Photos HD-34-1 and HD-34-2. 
wing across an inner courtyard, eventually containing 47,803 square feet. 138

Service Building (Steam Plant), TAN-603

The Service Building followed the same design already seen in non-shielded buildings at the IET and A\&M. The long axis of the building was east/west. Its plan was rectangular with basic dimensions of 192 feet long and 35 feet wide. A rectangular projection on the southeast end extended 18 feet. The building was flat-roofed and single-story, although the spaces equipped to service trucks and other vehicles had a higher roof profile. Walls were of pumice block bordered on the top with a coping strip. Trucks and other vehicles gained entry through overhead roll-up metal doors. The roof was studded with vents and boiler stacks. The foundation was at grade and made of poured concrete. Personnel doorways had canopies over concrete entry pads.

Vestibule-type projecting entries were provided on the east end into the dispensary and on the north side near the company store. Concrete ramps at grade level gave entry to the boiler room/steam plant and repair shop on the north side and the apparatus room on the east.

From west to east, the building enclosed a steam plant (an expansion of the original boiler room), locker room, bathroom, repair shop with auto lift and floor drain, tool and ladder storage, a company store, kitchen incinerator, garage with an auto lift, a kitchen, small offices, and an apparatus room. The apparatus room had a mezzanine. The rectangular projection enclosed the dispensary, consisting of an exam room, women's bathroom, lab room, exam room, and ward unit with one hospital bed. See HAER Photo Nos. ID-33-E-212 and ID-33-E-213. This building was part of the general ANP second phase "expansion" and enlarged in 1958 to make space for an additional boiler. ${ }^{139}$ 
Figure 13. Service Building, TAN-603. Views of the dispensary in 2003. Top: nurse's office and examining room. Bottom: Hearing testing booth. Source: INEEL Photo HD-39-1. 
Warehouse, TAN-604

Like the Service Building, the Warehouse was also oriented with its long axis east/west. It was made of pumice block topped with a concrete bond beam, flat-roofed, and on a concrete foundation. Doors were either metal overhead roll-ups or hollow metal for personnel. Concrete ramps or stoops gave access on the north and south sides. Small shed extensions accommodated paint storage and a tool shelter.

Most of the warehouse space was open for storage, but the east end contained a special room for the storage of chemicals, men's and women's bathrooms, service counter, and an office. The building was about 20 feet high, 162 feet long, and 68 feet wide. Over the years it was modified to meet changing needs. See HAER Photo Nos. ID-33-E-214 and ID-33-E-215.

Change House, TAN-606

Continuing the architectural themes of pumice block, coping strip, flat roof, and rectangular shape, the Change House was located along the Administrative Area security fence just east of the shoreline ridge/shielding berm. The building was 86 feet long (including the guard station on the south end) and 45' 4" wide (including the projection on the north end). Automobiles drove alongside the south facade of the building, where they passed under a canopied porch.

The interior included a locker room, a counting room equipped with hand and foot radiation detectors, a sample prep room, offices, and bathrooms with showers. Hampers were available for soiled clothes. See HAER Photo Nos. ID-33-E-216, ID-33-E-207, ID-33-E-208.

Water System Pump House, TAN-610

This pump house served one of two major wells at TAN. Located on the north edge of the Admin Area, the building functioned to shelter the pump, chlorine room, and a tank. It was 44 feet long and 30 feet wide and about 14 feet high. Access was via (one) metal roll-up door or either of two personnel doors. A monorail along the ceiling anchored a 2-ton lift. See HAER Photo No. ID-33-E-217.

Fuel Pump House, TAN-611

Again built according to the master style, the fuel pump house was 30 feet long, 14 feet wide, and 10.5 feet high. Its floor supported five concrete platform pads to carry the weight of tanks containing diesel or other fuels. The walls had a 1.5 foot thick layer of insulation. See HAER Photo No. ID-33-E-218.

Water Well Pump Houses, TAN-612 and TAN-613. Located near their respective water tanks, these small 
buildings departed for functional reasons from the standard flat roof observed at most ANP service buildings. These had gable roofs of moderate pitch, designed for easy removal should the pumps need maintenance or replacement. The siding in the gable ends was shiplap wood siding. The walls below gables and eave line were of pumice block. Each building was 17' 4" long and 12 feet wide. Their function was to shelter the pumps, valves, and switches pumping water from the aquifer to the storage tanks.

A note on the plans says that the roof was built according to standards required by the Idaho Operations office. These have 3 inches of mineral wool (a type of fiberglass) blanket insulation. See HAER Photo No. ID-33-E-219.

Other Admin Buildings

Rounding out the service buildings in the Admin area were the substation control house (TAN-605), a water pumphouse for fire suppression (TAN-610), and the guard house (TAN-601). These were similar to buildings already described. Buildings with TAN numbers higher than 650 appeared after 1961 .

\section{PART NINE}

\section{THE LOW POWER TEST FACILITY}

The Low Power Test (LPT) facility had been anticipated in the Air Force Master Plan. Although GE had been planning for it in the early 1950s, the design of HOTCE, its first reactor, was still underway late in 1955. Parsons was designing the control console for it. HOTCE (pronounced "Hotsie") was the acronym for Hot Critical Experiment reactor. GE engineers were working out parameters of heat transfer within the reactor core and figuring out how much power they would need to heat it to desired temperatures. The "hot" part of this reactor's name referred to its research mission to obtain information on the temperature coefficients of solid-moderated reactors, that is, the HTRE-3 reactor. 140

HTRE-1 had been under test throughout 1956 and produced air temperatures lower than GE's target. A major focus of GE research and experimentation, therefore, continued to be components and fuel elements that could survive and function amidst ever higher temperatures and nuclear flux. Each time a new material was proposed for a component of HTRE fuel, it had to be tested for its reaction to stresses and for its nuclear and kinetic characteristics.141 Successful materials had to be further evaluated for their "critical" qualities, the loading configurations necessary to initiate and sustain a chain reaction. 
The Low Power Test building contained spaces, or bays, for two low power reactors to operate simultaneously. Sherman McGarry recalled:

...GE used each bay individually for different core configurations and experimented with various moderating materials and cladding material to try and reach an optimum core, moderator, and cladding that would be tested at the IET and hopefully be the reactor system that would go into Weapon System 125 A. 142

GE completed the Design Criteria for the LPT in April 1956. Parsons' architectural drawings followed in November 1956, and construction progressed through 1957. Arrington Construction Company was the builder.143 Following familiar procedure, the Design Criteria supplied the architect/engineer with assumptions about the reactors it would contain and allowable doses of radiation permissible in various locations around the building. It described the work spaces that would be required, and specified the performance characteristics of water, heating, ventilating, and other systems.

The two reactor cells were not the same size. The smaller of the two was the north cell (room 101) and called the CE Cell. This became the home of HOTCE. The other cell, room 102, was called the IC cell for "initial criticality." staffing the reactors and the building would require a force of 24 people for each reactor, a total of 48 if both cells were busy.144

The architect was to assume that the maximum operating power of a reactor operating in either cell would be no greater than 5 MW (a high figure, and thus conservative) and that both might be operating at the same time. For shield design, the reactor core was to be assumed ten feet above the floor and otherwise centered in the cell. People outside the building or on the other side of the shielding wall in the control rooms were allowed $1.0 \mathrm{mrem} / \mathrm{hr}$ doses. In the counting rooms, the dose had to be one-tenth of that. 145

Siting

The Air Force Master Plan had specified an "isolated site" for the LPT. This was the only ANP work area situated east of Lincoln Boulevard. It was flat and about 1 1/4 mile southeast of the Administration area (longer by road), a prescribed safety distance.146 Once again, the northeast prevailing wind was a major siting consideration. Should an accident at the LPT area release radioactivity into the air, the odds favored the wind carrying it harmlessly away from populated areas. 
Because the LPT reactors were to operate at low power levels, they would not be generating a great deal of heat. Consequently, the LPT was exempt from heavy engineering resources typically required to dispose of heat when power levels were much higher. This fact translated into a fairly simple building layout and a modest support requirement.

The design philosophy at LPT was similar to that at A\&M: isolate the source of radiation and surround it with shielding. The two reactor cells were side by side, so they shared a shield wall between them and were otherwise surrounded by shield walls. The rest of the work spaces -- control rooms, counting labs, instrument rooms, offices -- were all located in the same building on the "cold" side of the shield wall. See HAER Photo No. ID-33-E-292.

Other buildings in the complex dealt with the water supply, electricity, and security. Thus, the site included well, pump, water tank, chlorination, and firefighting facilities, a substation, and a guard house. A security fence and sewage system completed the utilities. A communication tower was part of the main building. The Design Criteria called for a rail connection between LPT and the A\&M, but this was never installed.147

Like other ANP facilities, the LPT was fenced with security fencing and night lighting. The access road from Lincoln Boulevard, named McKinley Avenue (continuing the NRTS theme of presidents' names for NRTS connecting roads) branched (anticipating later construction) to Tyler Avenue and led to the LPT guard house. Outdoor electrical transformers were located near the well house for instrument power, heating panels in the reactor test cells, and for general lighting and power.

The Low Power Test Building, TAN-640 and TAN-641

When the NRTS assigned building numbers to LPT buildings, it regarded the two parts of the main building as sufficiently distinct in character that it assigned them two numbers. The "Assembly and Test" portion of the building contained the two reactor cells and was numbered TAN-640. The continuous shield wall on the west side of the cells divided them from the "Control and Equipment" side, or TAN-641, where work spaces included the control rooms, offices, a counting laboratory, change rooms, instrument room, data room, and rooms for electrical and mechanical equipment. Except for a tunnel below the control rooms, the building had no basement level.

The architectural distinctions between the two parts were striking. The reactor cells were made of concrete. Because of the overhead cranes built into its ceiling, the cells were high-bay structures, with a high roof elevation. The rest of the building 
used ordinary pumice block and had a lower profile.

Reactor cells. The two cells were constructed of poured (ordinary) concrete of varying thickness. The wall between them was four feet thick and extended four feet below floor level. The wall separating the cells from the control area was five feet thick up to the thirty-foot level. Then the thickness reduced to eighteen inches (from the outside in). See HAER Photo No. ID-33-E-260, noting side wall at left of view; and ID-33-E-291. The outside wall of the smaller cell was three feet thick; of the larger cell, two feet thick. The interior dimensions of the $\mathrm{CE}$ cell was about 30 feet by 34 feet. The IC cell was about 30 feet by 45 feet. In each cell, a bridge crane moved east/west across the full span of the cell. The larger cell projected farther toward the east than the other, breaking up the east facade.

The ceilings of the cells were reinforced concrete one foot thick with built-up roofing on top. Accommodating the crane gave a ceiling height of 43.5 feet. The exterior height of the building was 45' 9" above grade. As in the A\&M Hot Shop, whenever a pipe or conduit penetrated a shield wall, it was dog-legged twice (ie, Z-shaped) to prevent radiation from streaming through the conduit.

On the south side of the IC cell was a pumice block wall built six feet from the shield wall. Anyone entering the cell via the personnel door on its south side had to enter this passageway first. The passageway also offered a weather-protected route between the control room area and the IC reactor cell. On the north side of the $\mathrm{CE}$ cell was an equipment room that housed an air-conditioning unit for the CE cell. The exterior wall was likewise of pumice block. Anyone entering the personnel door to the cell had to cross the floor of the equipment room first. See HAER Photo No. ID-33-E-291.

The main access for the reactor and test components was on the east facade. Each cell had its own metal rollup door with openings 22 feet wide and 30 feet high, anticipating the possible future presence of HTRE components. The vicinity east of the rollup doors was, by administrative order and by exclusionary fencing, expected to be unoccupied during reactor operation. Fencing and locked gates prevented people from crossing in front of the rollup doors during operations. The east perimeter fence was 177 feet from the concrete facade of the IC cell. Beyond that a radiation fence prohibited anyone from coming within 1000 feet of the path of radiation. The maximum separation between the test cell doors and the fence was 1500 feet. Instead of a material shield, air distance attenuated radiation.148

Apparatus inside each cell included an overhead bridge 
crane. The capacity of the crane in the small cell was 10 tons; in the large cell, 5 tons. See HAER Photo No. ID-33-E-292. The "quick-connect" systems used elsewhere at ANP also had an application here. A box located on a pad in a corner of each cell held connectors located on the face of the box. From here, control lines went below the shield wall to a tunnel below the main floor, then up to a cable trench in the floor below the control room, and from there to the control panel in the control room.149 See cable tunnel location in HAER Photo No. ID-33-E-293, section $A$; and HAER Photo No. ID-33-E-261.

Heating panels lined the inside wall of each cell. These distributed power to the heating elements inside the reactor whenever a particular test required it.150

Because the test activities within the cell would relate to temperature changes, the cells were each equipped with heating equipment to maintain ambient air temperature within desired ranges during any season of the year. The IC cell had steam heating with a ceiling exhaust fan. The CE cell had a refrigerated air conditioning system, steam heat, and an exhaust duct in the ceiling for air flushing. For firefighting, the cells also had a carbon-dioxide system for flooding the cells in case of fire too large for hand-held extinguishers.151

Control and Equipment Area (TAN-641). This part of the building was one-story, rectangular, and flat-roofed. Its dimensions were 92 feet by 111 feet (north/south axis). Except for the southwest corner and a length of wall on the west side, the exterior walls were of pumice block.

The room at the southeast corner was the counting laboratory (room 110), where background radiation was to be as low as possible -- at least $0.1 \mathrm{mr}$ per hour. The walls surrounding this room were poured of ordinary concrete sixteen inches thick. Likewise the ceiling was concrete. Entry to the room included a short hallway, both sides of which were made of concrete. The counting room was 19' 2" wide along the south wall, and 26' 7" long along the west wall. This room, like the perimeter rooms elsewhere in the building, had no exterior windows. See HAER Photo No. ID-33-E-291.152

A 13.5-foot length of the west facade wall also was made of concrete about one foot thick. The room inside was the "special source" vault, which stored radioactive source materials used for calibrating instruments and similar controlled materials, all of which were kept under account. The walls of the entire room, 12 feet by 20' 7", were made of concrete. The door into the vault was made of steel, the only such door in a building full of wood or hollow metal doors. One had to know a four-number combination 
to enter this room. The ventilation system penetrating the ceiling was entrance-proof. Should anyone try to tamper with the door, an alarm registered in the main guard house at A\&M. No James Bond entries or escapes here. See HAER Photo No. ID-33-E-292.153

The two control rooms (103 and 105) were of identical dimensions at 30' by 27' 3". Each was equipped similarly: a broad U-shaped control panel facing the reactor cells, instrument panels, and acoustical-tile sound proofing. A data room was situated between the two control rooms. The control and the data room each had a ceiling scuttle (hatch).

A main corridor lay just west of the control rooms, and farther west were offices, bathrooms, change rooms, and an instrument storage room. Larger spaces on the north and west sides of the building included a shop called the assembly room. This was where instrumentation engineers attached foils to the fuel elements to be tested and otherwise prepared fuel elements for their tests. This room had "battleship linoleum" flooring for easy decontamination and a stainless steel sink for the decontamination of small components. The floor and sink drains carried liquid wastes to an underground tank buried underground outside the building. Tank trucks periodically pumped this tank and took it to A\&M for disposal and further treatment.154

A large room provided for the building's mechanical equipment, boiler, electrical switchgear, and diesel generator. The diesel generator was for emergencies in case of a power failure. It provided enough power to separate the tables of a split-table reactor, keep lights on the security fencing, heat and light the guard house, and keep the boiler and water system operating. Heating and ventilating systems kept the assembly side of the building under positive air pressure to prevent the entrance of contaminated air from the cells. The control rooms themselves were kept at a greater positive pressure than the rest of the building.155 
Figure 14. Low Power Test Guard House in 2004, shortly before demolition. Top: Visitor's view of Guard House upon entering LPT premises. Bottom: Entry to bathroom was via plastic curtain. Source: INEEL Photos HD-40-10, frames 17 and 18 . 
Guard House, TAN-642

A security fence surrounded the LPT site. This was an "exclusion" area where anyone entering had to have Q clearance and special permission.156 All passed through the fence at the Guard House, located northwest of the LPT building. This building, made of pumice block, was rectangular, one-story, flat-roofed, with windows on all four sides. It was 12 feet by 10' 8" in size. From grade to the top of the roof, it was 9' 10" high. Wall foundations extended at least five feet below grade.

The building contained a built-in counter, a bathroom, an electric space heater, and a two-way turnstile. The toilet occupied such a small part of one corner; it was covered by a curtain rather than a wall. The building was arranged to include a small waiting area. Hollow-metal doors with wire windows opened to all but the west side. See HAER Photo No. ID-33-E-294. After the ANP program, the guard house was enlarged slightly.

\section{Chlorination Building (TAN-643) and Pump House (TAN-644)}

The Chlorination Building was a small shed-roofed structure eight feet square. It was south of the LPT building and served to chlorinate (sanitary) liquids discharged to a settling tank and then injected underground via a well.157 The west facade contained the hollow metal door, and this wall was 8 feet from grade to roof eave. The walls and roof were made of "Armco 16 steelox" panels, arranged vertically. The north and south walls contained louvered vents. See HAER Photo No. ID-33-E-295.

The Water Well Pump House was 500 feet east of the LPT building. Part of it followed the design similar to those at the Admin area (TAN-612 and TAN-613) in that it had a gable roof over the part of the building housing the well and the pump. An adjacent east section had a flat roof. This section contained a chlorination room and wall-mounted space heater set to keep the building at least 40 degrees $F$. during the colder months.

The walls of both sections were of pumice block. Entry doors were on the north side. The gable ends had shiplap wood siding. A large roof ventilator (24-inch throat) sat atop the roof ridge. The building was 18' 8" long and 16' 8" wide. From grade to the top of the pumice block, the walls were 9' 10" high. Ventilated doors gave access to the gabled section. The south, east, and west sides had louvered vents in the walls and no windows. See HAER Photo No. ID-33-E-295.

The capacity of the electric-driven pump was 400 gallons per minute. In emergencies, a 40-horsepower gasoline pump was available. The water storage tank had a capacity of 75,000 gallons and was located north of the LPT building. 
The HOTCE Reactor

HOTCE was a "split table" type of reactor. Although not all low-power reactors that would operate in the LPT were of this type, they all had particular safety requirements and similar means of communicating between the reactor and the control room. This one illustrates the general function (despite unique fuels and core designs) of a low power reactor. See Appendix $E$ for a list of all the low-power reactors that operated at TAN.

Fuel elements were loaded horizontally into two matching sections kept apart from one another (split) until criticality was desired. One side, mounted on wheels, could then be moved toward the stationary side to bring about a critical mass. A variable-speed motor moved the table, but, for safety, at pre-set speeds. As the sides came within six inches of closing, the speed reduced to a maximum of three inches per minute. 158

The reactor had a hydrided zirconium moderator and a beryllium reflector. The 151 fuel elements were arranged in a hexagonal matrix. Extra space was available for expanding the fuel cells to a total of 169. To raise the operating temperature, strips of electrical resistance wires were attached to fuel-heating elements or against the outer surface of the beryllium reflector. The whole reactor apparatus rested on a special platform inside the CE cell.159

HOTCE's uranium-235 fuel, 93.2 percent enriched, was packed inside a stainless steel wire $1 / 8$ inch in diameter and wound around the outside of a ceramic tube. The elements were 30 inches long. The moderator was in the form of a hexagonal zirconium bar, treated to contain a substantial quantity of hydrogen atoms. Each fuel element fit inside the hollow center of the bar. The hydrogen slowed down the neutrons leaving the fuel element to a speed that promoted fission when the neutrons hit uranium atoms in neighboring fuel elements. Some of the corners in the hexagonal bar were rounded so that control rods containing boron carbide (in a possible 122 positions) could be inserted into 
Figure 15. The HOTCE reactor. Top: Fuel element shows heating wire wrapped around fuel. Center: HOTCE reactor, sketched with movable half separated from stationary half. Bottom: HOTCE control console. Source: J.A. Hoefer, APEX-345. 
the midst of the fuel. Surrounding the core, a beryllium reflector four inches thick bounced neutrons back to the core region.

The stainless steel fuel wire also acted as a heating element during tests. One end of the wire was grounded. The other end was connected to electricity. Resistance heating raised the temperature of the wire, and the rest of the core was heated by heat radiation and convection from the wire. With this set-up, the fuel could reach a maximum temperature of 1600 degrees $F$, and the moderator and reflector could reach 1300 degrees $F$. The object of research was to mock up various temperatures likely to be encountered in the actual airplane reactor and study the results. 160

Various rules of procedure governed operations before, during, and after criticality. Management of the reactor centered in the control room, where panel indicators, switches, selectors, amplifiers, scalers, chart recorders, scanners, and signal readers all informed the two (required) operators. Typical practice was to operate at a one-watt power level for one to three hours. Before startup, the engineer-in-charge was personally responsible for inspecting the test cell to make sure it was empty of people and then lock the cell doors.

HOTCE ceased operating when the ANP program ended in 1961. However, the LPT cells and control rooms were homes to five more low power reactors.

PART TEN

\section{THE SHIELD TEST FACILITY}

Shielding a crew in a nuclear airplane required innovation and a departure from standard "unit" shielding surrounding only the reactor, which would be too heavy. The Comprehensive Technical Report written after the ANP program ended described the "divided shield" idea:

It was soon recognized, however, that a lower total shield weight could be achieved by dividing the shield between the crew compartment and the reactor. The combined shield thickness directly in line between the reactor and crew was about the same in either arrangement. However, shielding on the side of the crew compartment was more effective than an equivalent thickness on the side of the reactor because the scattering process reduced the energy of the radiation reaching the crew compartment. Hence, a thinner shield could be used, resulting in less weight.161 
At least, that was the hope. The scattering behavior of neutrons in air was a sufficiently difficult problem that some observers wondered if a crew who completed one mission would simply have to retire, having acquired a lifetime radiation dose.

GE originally proposed to test prototypes or mockups of the aircraft engines and shield configurations and test them in Idaho at a building called the shield Test Facility (STF). It was to be completed in the spring of 1959.162 Early drawings show a control building with an apparatus for suspending a reactor outdoors to the west of the building. Test packets were to be situated on a turntable and exposed.163 However, the Air Force and the AEC financed such a facility at Oak Ridge. Known as the Tower Reactor, this reactor began operating in the early 1950s. GE and Oak Ridge scientists carried out major shield studies there with generous funding by the Air Force. This facility obviated the need for another one in Idaho.164 GE decided that if they need to do air scattering tests in Idaho, they could use the IET. The outdoor platform idea and its earth-covered control room were abandoned. 165

Instead, the Idaho facility was designed to do scattering tests in water. A low power reactor would operate within a pool of water. As GE wrote, this set-up had virtues such as "inherent safety features, its adaptability to extensive nuclear research, its simplicity and minimum cost."166 In a typical test, physicists suspended a "slab" of material about four inches from the reactor core. Measurements were made of gamma-ray and neutron doses, nuclear heat rates, spectral and thermal neutron flux, power calibration, temperature coefficient of reactivity, and others.

The biological shield for workers at the Shield Test Facility relied on the same principle as at other "swimming pool reactors," by this time not uncommon at universities and industrial laboratories elsewhere in the country. A sufficient depth of water acted not only as a shield, but also as the coolant and moderator for the reactor, which operated within the pool. The weather-enclosure building required no super-dense concrete, no complicated gamma ray calculations, and no investment in mazes, Z-shaped conduits, and stepped plugs. On the other hand, maintaining the pool's water quality called for a certain quantum of specialized plumbing.

\section{Siting and Layout}

The swimming pool reactor was a low-power reactor. The building site was just west of the LPT building. Its east wall was about 90 feet from the LPT's west wall, and its rectangular construction was oriented to the same points of the compass as the LPT. The relationship between the pools and the control and 
equipment portion of the STF building was similar to that at the LPT, except that the reactor pools were on the west side of the building, not the east. This arrangement put additional distance between the reactors and pointed the impact of any potential blast accidents away from worker-occupied areas. The STF shared the LPT's security fence, guard house, sewage plant, utility lines, and roadway. During the ANP program, the only people entering the STF were Q-cleared personnel with a need to know.167

By design or good luck, lava bedrock at the STF site was about 30 feet below grade, a factor helpful in reducing blasting requirements for the foundation of the two pools, which lay about 30 feet below grade.

Following a similar numbering logic as for the LPT, the NRTS regarded the STF as two buildings. The pool side was considered the "Pool Facility Building," TAN-646. The "Control and Equipment Building" shared a common wall with the pools, but was numbered as TAN-645.168

Shield Test Facility, TAN-645 and TAN-646

The building had two heights. To accommodate a bridge crane over the two pools, the high-bay section was 46.5 feet high between grade and the roof line. The rest of the building was one story at 15' 2" high. Roofs were flat. The high-bay section was primarily a weather shelter over the pools. Framing consisted of structural steel columns, tapered girders, steel purlins and metal roof decking. The siding was insulated corrugated asbestos-cement siding. The one-story control building was framed with structural steel and sided mostly with pumice block. An exception, along part of the north facade, was for the special source storage room. Along this room's 31-foot length, concrete interrupted the pumice block siding. The roof consisted of a vapor barrier, insulation, built-up roofing surfaced with double gravel over the metal decking. Roof ventilators exhausted air from the pool building at a rate of three air changes per hour. 169

The control building (TAN-645) was a rectangle 70 feet wide by 92 feet (north/south axis). The high-bay pool building was rectangular, 142 feet long (north/south axis) and 46 feet wide. Most of the high-bay's excess length projected to the north side of the building, with about ten feet projecting to the south. On the west side, another projection 52 feet by 18 feet contained equipment pads and an access stairway to the basement levels. See HAER Photo No. ID-33-E-296.

Below the pools were basement and sub-basement levels, providing access to utility coupling connections for reactor experiments, a storage room, and a cable equipment room. A 
corridor ran between the two pools and continued beneath the control side of the building for a distance of about 53 feet. The subbasement gave access to a pump room and sumps. Most of the one-story part of the building had no basement. See HAER Photo No. ID-33-E-298.

The Pools. The purpose in having two pools was to allow testing to proceed in one while mockup work could be done in the other -- a substantial saving of time.170 The pools were built below grade. Pool No. 1 was on the north side; Pool No. 2 on the south. Each was the same size at 40 feet long (north/south axis) and 25 feet wide. They were each 30 feet deep, with the pool floor sloping slightly. The entire pool room was open, with no other partitions or walls.

The (ordinary) reinforced concrete walls and floor of the pool were 1' 7" thick. The concrete and the earth beyond provided biological shielding on all sides, while the depth of water above the reactor absorbed any radiation emanating from the reactor top. Counterforted walls meant that each pool could withstand the pressure when water filled the pool or when it was empty. The pool bottom could support a concentrated load of 25 tons on one square foot and a maximum of four such loads spaced ten feet apart. A protective coating called "Phenolene 300" was painted onto the walls and floor of each pool.171

The open floor area north of Pool No. 1 was 38.5 feet long. It accommodated a 50-ton bridge crane and its cables, which could be moved here out of the way during an experiment. The crane, with a 5-ton auxiliary hook, traveled the entire length of the pool room. This area also provided the main entry into the pool room. The door was insulated, about 20.5 feet wide, and located on the east side. It hung on a channel frame. In its open position, the clear opening was 27'3/4" high. The door was in an open position when slid to the north end of the channel.

A 3-foot high concrete parapet surrounded each pool, strengthened by vertical struts at 3 -foot intervals. A rail was set into the top of the parapet on the north and south sides of each pool as part of the reactor support. A personnel ladder allowed entry into each pool. SCUBA diving suits were routine equipment around the STF.

A distance of six feet separated the two pools. Below deck, this space was occupied by the main basement tunnel, which ran east-west and extended into the control side of the building. It gave access to the coupling station and cable connections. A pump room on this level provided great flexibility for managing the pool water. Water could be pumped from one pool to the other or drained to the sanitary waste system. If the water became 
contaminated, it could be pumped to a tank truck and sent to the A\&M for disposal.172

The building projection west of the pools was known as the water-treatment building. It contained pumps and related water-treatment supplies. Water in the pools was demineralized. Concrete pads provided places for water softeners, deionizers, disposable resin ionizers, pool filters, an acid neutralizing pit, caustic, pH controller, rate-of-flow controls, oil filter, and additive mixing tank. A frost-proof emergency shower along the west wall was equipped with a quick-opening valve and a pull chain. The eye wash station was on the east side nearer the caustic and acid storage tanks. Just outside the building on the north side was a below-grade salt storage pit. See HAER Photo Nos. ID-33-E-301 and ID-33-E-302.

The Control and Equipment side contained the familiar suite of work spaces necessary to prepare and operate a reactor experiment: instrumentation and calibration labs, counting room, control rooms, data rooms, change room (capacity for 20 men), offices. The building services had their equipment rooms: boiler, water treatment, diesel generator, and mechanical equipment. It was a conventional building framed with structural steel.

Special sources resided in Room 102, the Calibration Lab. It was 26 feet long by 16 feet wide (interior dimensions). The walls were 2.5 feet thick and made of ordinary poured concrete. Plans show that six wells were to have been built flush into the floor as storage units for radioactive calibration sources, but these apparently were not installed.173 A monorail and electric chain hoist hung from the ceiling to facilitate moving heavy casks. The "shield door" was made of reinforced concrete and quadruple-hinged. A U-shaped handle on each side provided a stout grip for anyone pulling on the door. It was 7 feet high, 4' 7 1/16" wide, and 2.5 feet thick. See HAER Photo No. ID-33-E-300.

The counting room was south of the vault and shared part of a common concrete wall. Technicians here counted radioactive samples used in the tests. This room was 20 feet by 11 feet and enclosed with one-foot-thick concrete walls on all sides. The concrete walls and positive-pressure ventilation helped keep background radiation as low as possible. The door was hinged, made of steel one inch thick, and weighed 300 pounds.174

The control and data room (room 109) was 42.5 feet (east/west axis) by 20 feet and walled with pumice block and acoustical tile. Its west side was adjacent to the pools and contained a (non-shielded) viewing window into the pool room. 
A typical test might begin with a truck from A\&M delivering a test set-up to the pool building. The overhead bridge crane would position the assembly for connections to its (flexible) electrical, implementation, and other leads and hoses. The crane would then place the entire lot inside the indicated pool. When the experiment was ready, operators would move the reactor next to it and bring the reactor to criticality. Typically, the reactor operated at a power level between $10 \mathrm{kw}$ to $100 \mathrm{kw} .175$

The reactor core was supported by an aluminum structure that hung from its own movable bridge. The bridge, made of welded steel, traveled up and down the rail along the pool length, so that the reactor could be placed anywhere along the centerline of the pool. The frame could be detached from the bridge, allowing the overhead crane to move it to the other pool. (Procedure manuals permitted this only when the fuel had been removed from the core.) For critical operations, the top of the fuel was at least 17 feet below the water surface.

Fuel was positioned at the bottom of the support frame. The grid plate had spaces for as many as 54 fuel elements in a $6 \times 9$ array. The aluminum-clad fuel elements were similar to those used by the Materials Test Reactor elsewhere at the NRTS, shaped as curved plates about three square inches. They contained uranium enriched to greater than 90 percent.

Fuel rods, control rods, ion chambers and other sensing devices and leads were all enclosed in watertight tubes that extended above the water level. The actuators (mechanisms to move the control rods) were mounted a few inches above the bridge floor. A comprehensive system of lockouts were built into the moving parts of the apparatus to prevent such actions as moving a loaded reactor. Scram buttons were available on the reactor bridge and in the control room. The key to the reactor console was kept in a locked safe.

Post-1961 Activity

GE continued to run the Susie reactor after the ANP program shut down, although no longer in service to the ANP. After the shutdown, the AEC assigned GE to examine the debris from the SL-1 accident of January 1, 1961.176 Susie proved to be a popular and versatile instrument for scientists located elsewhere at the NRTS. 177

It could be rigged and shielded, for example, so that exposing a sample to its different "faces" allowed different radiation exposures. During a test series when organic coolants were under study, for example, the east face was "gamma rich," while the north face was "neutron rich."178 
By the end of 1962, however, Susie was no longer in use. But the Shield Test Facility lived on, its pools drained and adapted for a new reactor concept called EBOR, discussed in Part Twelve below.

\section{PART ELEVEN}

\section{MARITIME REACTOR PROGRAM AT TAN}

The AEC and the U.S. Maritime Administration jointly wanted to develop a reactor suitable for propelling commercial maritime vessels, hoping ultimately to reduce the general cost of shipping. They inaugurated the Maritime Gas-Cooled Reactor program in 1956. Nuclear fuel for long-haul cargo ships promised compact fuel, larger cargo space, and multiple trips without refueling. Tankers and ore carriers, in particular, could profit from economies of scale, fast speeds, and less time in ports.179

Around 1961, after President Kennedy canceled the ANP project, the two agencies contracted General Electric to develop the "630A Maritime Nuclear steam Generator." The project was under the management cognizance of the AEC office in Oak Ridge, not the Idaho Operations Office. GE did most of its development work at its laboratory at Evendale, Ohio. The objective was to develop an air-cooled, water-moderated reactor to produce steam for propulsion. The contemplated ship was a 30-knot cargo vessel capable of making thirteen 28-day round trips of 14,000 miles each. Under this scenario, the reactor could be refueled every 2.6 years. 180

While working on designs for blowers and drive turbines, loadings imposed on equipment due to the motion of a ship, remote handling techniques, the proper thickness of the ship's reactor vessel, and how to maintain the integrity of the reactor vessel should the ship sink, GE required the aide of a critical experiment reactor. Space was available in one of the cells in the Low Power Test Facility, so GE, already quite familiar with this facility, set it up there.

The small low-power $630 \mathrm{~A}$ reactor went critical for the first time in 1962. (Available reports do not indicate which of the two LPT test cells it occupied.) The hexagonal fuel grid had positions for 85 fuel cartridges and 132 control rods when fully loaded. It allowed for the testing of various fuel and control rod configurations. Before the program shut down, detailed nuclear measurements had been taken for at least two different core configurations.181

Other than designing the test apparatus, reactor stand, and 
scaffolding surrounding the reactor for any given series of tests, the operators of the $630 \mathrm{~A}$ critical experiment reactor appear to have made no demands on the basic architecture of the Low Power Test facility.

By spring 1964, GE was evaluating the feasibility of adapting the IET for ground testing a 630A prototype reactor. It contemplated using the west side of the trackage near the coupling station for installing a below-grade boiler, a heat dump, a crane, and a new personnel change room and access tunnel. 182

However, the AEC suspended the 630A project on December 31 , 1964, and ultimately canceled it. This act was attributed to an economic comparison between the air-cooled reactor concept and the already proven pressurized-water concept. While the 630A system would cost relatively less to install than a pressurized-water system, the long-range fuel-cycle cost of the 630 A would more than offset it.183

PART TWELVE

\section{THE EXPERIMENTAL BERYLLIUM OXIDE REACTOR (EBOR)}

As part of its program to explore a variety of reactor concepts, the AEC approved the development and testing of a high-temperature, beryllium oxide moderated reactor to be cooled by helium gas. The AEC hoped the concept would produce low-cost electricity, propulsion (of surface ships), and process heat. Construction began in Idaho in June 1963.184

General Atomics (GA), a division of General Dynamics Corporation with laboratories in San Diego, California, had designed the reactor and made the proposal to the AEC to operate and test it. As usual, a new concept had to be explored for its performance in a wide range of normal, transient, and emergency operating conditions. GA had begun its studies in San Diego with a series of critical experiments on candidate fuels.185 The attractive possibility of a high-temperature reactor was that it might burn a higher percentage of its fuel than was typical in other reactors. The combination of uranium oxide and its beryllium oxide moderator was considered likely to survive in a high-temperature environment. The program anticipated testing fuels such as thorium-uranium and plutonium as well.186

Beryllium is a light metal. Its salient characteristic was that it does not absorb neutrons easily, but bounces them back and slows them down. In a reactor core, therefore, it would slow the fissioning neutrons and promote a chain reaction. ${ }^{187}$ 
The AEC decided that the project could adapt the shield Test Facility. One of its pools, drained of water, would supply a ready-made shield for the reactor. Because the experiment focused on the reactor, no provision was made to generate electricity. Reactor heat would be collected by helium gas and dissipated to the atmosphere. The helium would recycle through the reactor. ${ }^{188}$

Managing helium gas as the coolant required a significant outlay in new engineering at the shield Test Facility. The building had been equipped originally to manage water, but the water works would not manage helium. GA hired Kaiser Engineers, a division of Henry J. Kaiser Company of Oakland, California, to design the remodel for the new reactor and a helium wing.

Kaiser completed the engineering drawings in May 1963. The M.W. Kellogg Company, a division of Pullman, Inc. of Idaho Falls, was hired to build. Construction began shortly thereafter, and the facility was handed to GA in January 1966.189

Fabrication of the 200-ton steel reactor pressure vessel was contracted to Pacific Coast Engineering Corporation of Alameda, California.190 The vessel was shipped to Idaho on a flatcar in November 1964. Press coverage at the time referred to it as a "big nuclear kettle."191

Things did not go well in the early installation phase of GA's operations. On February 22, 1963, during a test of components, about fifty gallons of oil were accidentally injected into the helium piping, the primary coolant loop into the reactor vessel.192 Cleaning this up proved to be a tedious and distracting chore that delayed other installation activities. Even small traces of oil in the system would constitute a contaminant in the reactor. Months later, oil was still showing up in piping side seams.193

Parallel with construction and component testing, the safety characteristics of the reactor underwent detailed scrutiny. The AEC's Advisory Committee on Reactor Safety (ACRS) evaluated GA's 1962 draft Safety Analysis Report, which identified operating procedures, possible accidents, potential releases of radioactivity into the environment, and the response of the reactor and personnel to such events. Among many concerns, the ACRS questioned whether there were enough safeguards to keep the reactor fuel from melting if the helium coolant failed. It also noted that GA expected an operator to remain in the control room for up to an hour or more after an accident; it wondered if the control room had adequate shielding to keep such a person from receiving an excessive dose of radioactivity if contaminated helium were released into the reactor room. GA thus investigated the possibility of using the shield Test Facility's counting room 
Safety discussions continued into 1965 and 1966. Other mishaps occurred. In March 1965, the EBOR crew started the main helium blower. The sudden draw caused a complete power outage next door at the Low Power Test facility, where GE was involved with a low power reactor program. The EBOR manager had not informed GE of the possibility of this type of interruption.195

Concerns about EBOR's safety and managerial deficiencies finally arrived at the desk of Milton Shaw, the director of the AEC's Division of Reactor Development and Technology. He asked the IDO manager to "surveil" GA's progress and to keep him informed of various management difficulties sprouting up due to the fact that EBOR was under the technical control of the AEC's San Francisco office. 196

Milton Shaw had been a protege of Admiral Hyman Rickover, the "father" of the Nuclear Navy and noted for being committed to total safety and quality in nuclear operations. He had been critical of start-up problems at the NRTS's Advanced Test Reactor in 1965. EBOR difficulties undoubtedly contributed to his growing view that profound reform in reactor research at AEC labs was in order.197

Shaw did indeed initiate many reforms. The one that most affected EBOR was a decision to narrow the focus of the AEC's reactor development program. Instead of spending resources on a variety of reactor concepts, Shaw decided that the AEC should focus on breeder reactors, a concept with potential to burn up most or all of its uranium fuel. Investments in non-breeder concepts like EBOR were precipitously cut.198

The press release announcing the end of EBOR came in December 1966. Officially, EBOR was making a "diminishing contribution" to the AEC's reactor program. Closing it was "consistent with continuing efforts of the AEC to assign available resources, including funds and personnel, on a priority basis to those reactor concepts with the best promise of economic power production and more efficient use of nuclear materials." The release went on to suggest that beryllium oxide as a moderator was an alienate for graphite as a moderator, and that graphite had already advanced to commercial application in the Peach Bottom (Pennsylvania) and Fort St. Vrain (Colorado)

reactors. EBOR was dead; its reactor vessel had never been loaded with nuclear fuel.199

Siting and Layout

Once the decision had been made to adapt the STF, no further siting considerations were necessary. The control side of the 
building required relatively little alteration to continue in service to the new experiment. The pool room was the focus of alterations. Managing helium required a new wing on the west side.

The plan was to remove the water from both pools and then take advantage of their ready-made below-ground shielding qualities. EBOR and its massive steel cap was placed in Pool No. 2, the south pool, near its bottom. Henceforth, the pool was thought of as a "vault." The north pool was equipped with racks for storing fuel elements and control rods.

West of the pools, the projection that contained water management equipment remained in place, parts of it somewhat obsolete. The new wing continued to the south. At its southwest corner was an exhaust stack which was enclosed by the building and penetrated the roof.

Other buildings around the site continued in service: the sanitary sewer, water pumps, water tank, guard house. However, a new pump house with specialized fire protection functions was built (in 1965) a short distance north of the pool building and just west side of the water storage tank.

The Experimental Beryllium Reactor

EBOR was to be contained in a cylindrical steel vessel about twelve feet in diameter and rounded on the bottom. Fuel was to be loaded from the top by removing its equally thick and rounded "head." The coolant duct penetrated the pool wall. After the duct and other hoses and pipes projecting from the reactor had been installed, part of the void between the reactor vessel and the pool walls was filled with concrete. Ordinary concrete composed the lower 17 feet, but special high-density concrete was used above that level. A high-density concrete cover fit the top of the reactor vault for shielding during reactor operation. The cover was of a stepped design similar to shielded plugs used elsewhere at TAN. Pipe and conduit that penetrated the shield around the reactor were Z-shaped. See HAER Photo No. ID-33-E-305, sections A, C, and D. One of the many management reports on EBOR problems observed that the reactor vessel's head weighed 57 tons, while the overhead crane was rated at 50 tons. No one from GA had analyzed this mismatch to assure themselves that it would not create future problems. 200

Although EBOR never went critical, a series of photographs taken of the pressure vessel, its outlet port for the helium duct, pressure vessel head, control rod nozzles, reflector support tank, and other finely machined one-of-a-kind structures are illustrative of the type of work taken to prepare any test reactor. See HAER Photo Nos. ID-33-E-282 through ID-33-E-289. 
The New Wing for EBOR, TAN-646

Most features of the new wing related to helium. The wing

lay along the existing west wall of the STF building. It was roughly 21 feet wide and 124 feet long (north/south axis). A small projection (rooms 126 and 127, battery storage, diesel generator set) along the west side of the new wing was about 40 feet long and 15 feet wide. Another projection on the west side of the wing at its south end (room 125) was an enclosure for the helium-to-air cooler and the stack above it.

Other features of the wing were liquid nitrogen (a coolant) storage tanks, helium purification equipment, a compressor, dust removal equipment, decay-heat removal blowers, emergency cooling compressor, filters, and iodine removing equipment. The helium-related rooms were built with concrete walls two feet thick. A portion of the wing had a second story level, and the siding for this section was insulated corrugated asbestos cement. See HAER Photo No. ID-33-E-306.

Below grade, significant additions were made in the corner created by the existing wall south of the pool and the east facade of the new wing. Piping was to circulate the helium between the reactor and the cooling facilities. The pipes entered a new basement room (Room 124), which was equipped with vacuum pumps, valves, a stack monitor, and control panel. A monorail with a door opening on the south end of the wing facilitated deliveries into and out of the wing. Hatches through the floor to Room 123 below provided openings to the ground floor. See HAER Photo No. ID-33-E-304.

EBOR Changes to Existing Structures of TAN-645 and -646

The wall between the pool chamber and the control side of the building sustained little impact in the EBOR remodel. A new door opening was made in the wall between the pool room and the men's change room (Room 107). Although this room is just south of the shielded counting room, it appears that GA did not proceed with any plans convert it to an emergency control room.

The boiler room was expanded for a new boiler. This appeared at the southeast corner of the existing building, a small addition of 10 feet wide by 28' 8" long. See HAER Photo No. EBOR-ID-33-E-304.

\section{Pump House, TAN-652}

The exterior design of this small utility building continued the design theme of rectangular buildings with pumice block siding and a flat roof. The building was 30' 8" long (east/west axis) by 20' 8" wide. It was divided into two rooms, each with a hollow metal door on the south side and a roof ventilator on the steel deck roof. Equipment pads were built into the concrete 
floor. A hose manifold sleeve projected from the front wall. See HAER Photo No. ID-33-E-303.

Later Uses and New Names for the Shield Test/EBOR Facility

With EBOR canceled, the Shield Test/EBOR building was available for other uses. The NRTS became the site of major studies and experiments in the safety of large commercial reactors that were being built in the United States in the $1960 \mathrm{~s}$ and 1970s. Some of the studies took place in the shield Test facility, which was renamed the Semiscale Test Facility. The Low Power Test building next door was renamed LOFT Test Support Facility. The general area was called the water Reactor Research Test Facility (WRRTF, pronounced "wertif"). In this incarnation, WRRTF supported non-nuclear tests related to loss of fluid and other safety studies of commercial power reactors.

After LOFT programs ended in 1986, the old STF was the scene of acoustic tests for detecting flaws in the pipes and piping of reactor vessels. This work was carried out by the southwest Research Institute under contract to Edison Electric and the Tennessee Valley Authority. Another program tested systems used to detect explosives.201 Both the LPT and STF buildings have at last run out of missions. They are being demolished. PART THIRTEEN

\section{FLIGHT ENGINE TEST FACILITY}

The fifth operating complex for the ANP program was the Flight Engine Test (FET) facility. This huge airplane hangar is a worthy symbol for the optimism shared by U.S. Air Force and General Electric that they would produce a nuclear powered airplane. Its architectural details, siting, and layout have been described in HAER Report ID-33-A. The hangar -- with its shielded control room -- was for ground testing the future airplane.

Merely proving the principle of nuclear propulsion had required the major ANP industrial facilities thus far described. Handling an airframe would be equally complicated, requiring great forethought and planning. Engineers would have to perfect methods for removing the power plant from a radioactive and possibly damaged airplane, service and replace its major components, reactor included. Ground crews would have to be trained in all manner of safety routines and remote-control procedures -- in all weather conditions.202

The Photo Index to HAER ID-33-A contained photographs and drawings only of the hangar, TAN-629. In 1995, when that report was published, demolishing its control building (or any other FET structures) was not contemplated, so the report included photographs and drawings only of the hangar. Demolition of the 
control building is now planned. (The Hangar continues in use as a shelter for the Specific Manufacturing Capability project, which manufactures tank armor made of spent uranium.) It is appropriate, therefore, for the present report to record the rest of the FET.

The IET shield philosophy was repeated at the FET. Since the radioactive source -- the airplane -- would be mobile, the stationary control room was shielded. As at IET, it was bunkered under a thick blanket of earth. It was the center of remote-controlled operations, connected by wire and conduit to a Coupling station inside the hangar. The shielded locomotive on the four-rail track would push the airplane into position for quick plug-ins to leads and hoses. A platform elevator on the hangar floor (planned, but not built) would convey a dismantled reactor/power plant from the airplane to the basement.

\section{Siting}

As a source of radiation, the hangar complex had to be isolated and distant from other work areas. It required a logical relationship with the planned runway. The separation distance from the A\&M was 8,000 feet in a west/northwest direction. Had the runway been built, it would have been west/northwest of the hangar and connected by a 1200-foot-long taxiway.

The early vision of the ANP designers had been far-reaching. They had assumed that Pratt \& Whitney's closed-cycle airplane might also require its own hangar in the Idaho desert someday. Sherman McGarry wrote:

West of the runway were preliminary drawings for other airport type support facilities including a control tower, a decontamination facility for the aircraft, and a large parking ramp. Beyond these facilities...another complex was going to be built by Pratt \& Whitney for their engine and craft support they were also working on. These never got beyond the location [stage] with an unspecified on/off ramp that would also use the runway. Not much was ever known about the Pratt \& Whitney interface beyond locating them west of the runway control and maintenance facilities.203

The ANP designers had anticipated nothing but a forward trajectory into the successful long-range achievement of their goals. In these early years of the cold War, they were nothing but optimistic.

Layout

As it was built, the FET area consisted of the hangar building (TAN-629), the bunkered control and equipment building to its immediate east (TAN-630), buried fuel tanks south of the 
bunker, and a tank building further south (TAN-631). The plan included a decontamination building, a nuclear service building, and a transfer station, none of which were built.204 GE designed a "mobile shielded cab vehicle" (known as "the Beetle") to aid remote operations inside the hangar, but it never saw service in Idaho. GE used it at another of its projects. ${ }^{205}$

From the railroad turntable at the A\&M, another set of tracks went westward toward the hangar, whose massive front doors opened to the south. The rails entered the hangar for delivery of an airplane to the coupling station near the north wall.

The basement below the hangar contained tunnels connecting to the control room next door. One was for the Beetle driver who might have to escape in an emergency. Another was for the airplane crew, who would disembark down a heavily shielded hatch in the Coupling station. The tunnels led to a decontamination area containing a shower and change lockers. The crew would go through this area for checkups and debriefing on their way to the stairways of the control room's first floor. Other tunnels and conduit provided access for electrical, fuel, and other service leads.

On the east side of the control building were two shielded entrance tunnels. One entrance was a pedestrian access into the first floor. The other was a shielded roadway, farther north on the east side, sloped downward to the basement level, where there was a vehicle turnaround area. See HAER Photo Nos. ID-33-E-308 and ID-33-E-310.

As usual at all ANP complexes, security/safety fencing and emergency security lighting with standby power girded the project area. Also as usual, GE directed that "New facilities shall be similar in construction and appearance to existing facilities..." In this case, it also said, "Particular consideration must be given to the unique and unusual requirements of this facility...higher degrees of reliability than in normal industrial practice. Margins of safety are to be large..."206

The Control and Equipment Building, TAN-630

The Control building was built of reinforced concrete all around. It had two levels. The building was rectangular and flat roofed, 94' 2" wide and 105' 2" long on the north/south axis. The walls were three feet thick and poured of ordinary concrete. Atop the concrete roof, the earth shield was a minimum of 6.5 feet thick. See HAER Photo No. ID-33-E-310. Small projections provided for air intake and exhaust equipment.

The first floor housed the control room and consoles, data rooms, health physics laboratory, conference areas, change rooms, 
auditory alarms, and communications center. One of its unique features was a corridor (room 123 A) leading from the control room (room 123) to the east wall of the hangar. Here observers could see into the hangar through a shielded window. Another corridor (room 104) led to a door into the hangar. On the hangar side of the door was a "shadow shield." Constructed of heavily reinforced concrete, this erect, massive slab would help block the force of explosions and fissionable materials from entering the Control building.207

The change room and bathrooms could handle up to sixty men during any one shift. Facilities included hand and foot counters, lockers, clothes hampers, showers, and toilets. Elsewhere a women's lavatory acknowledged that there might be as many as "six women per shift" somewhere in the control building.208

The shielding around the counting room attenuated background radiation to $0.10 \mathrm{mr}$ per hour during tests, the same standards in other ANP counting rooms. This room, 10 feet by $17^{\prime} 4$ " in dimension, was near the center of the building and enclosed in concrete walls one foot thick. The door (door 31) was equally thick, triple-hinged, and had a latch/bolt lock.

The basement floor housed the majority of the equipment servicing the various support systems: boilers, diesel generators and fuel pumps, dry chemical storage, acid and caustic storage and pits, electrical panels and cable, alarm terminal cabinets, heating and air conditioning equipment, instrument repair area, jet fuel transfer room. Personnel tunnels connected to the hangar from the change Room, carefully routed to fit between the structural ribs of the barrel-vaulted hangar. One went to the Coupling station, another to an access hatch under the four-rail track. Another tunnel went to a viewing station. A completely equipped "emergency kitchen" was to be stocked to feed thirty people for 72 consecutive hours on an emergency basis.209 See HAER Photo No. ID-33-E-309.

The exhaust and filtering systems were expected to be similar to the one at the IET, costly features consisting of ducting, filters, couplings, support foundations, valves, manifolds, and monitoring systems. They were to be arranged in a straight line north from the Coupling Station, ducted through the hangar's north side through a bank of filters, to the stack. Filters would remove radioactive dust particles from exhaust air before it went up the stack. 210 The system was not installed.

A fuel pump room was on the south side of the building, where it connected to buried tanks just beyond. They were intended for fuel oil, diesel fuel, lubricating oil, jet engine fuel, process water, fire protection water, and fire-suppression 
foam solutions. Also outside the building, a weather monitoring system with leads to the control center inside would constantly surveil wind speed and direction and other factors at all times during operations.211

\section{Tank Building, TAN-631}

This building sheltered several tanks in a space 29' 4" wide, 55' 4" long (north/south axis), and 15' 10" high. It was flat-roofed with metal decking and built-up roofing. Walls were made of pumice block. Unlike earlier ANP buildings, this one did not have a coping strip just below the roof line. Part of the wall on the north facade included a knock-out panel, a precaution against explosions.

Inside, the concrete floor of the building had built-in concrete pads and tank saddles to fit the future tanks, which would lie on their sides. Two hollow metal doors (not glazed) gave access to the east side, a double door to the south end, a single-wide door to the north. A dip stick rack was mounted on the west wall near the south end of the room. A trench and sump were built into the floor on the north end. Also on the north end, identified as the equipment room, was an exhaust vent and hatch to the roof. See HAER Photo No. ID-33-E-313.

Chlorination Building, TAN-637

The FET area included a sewage treatment facility east and slightly south of the Control Building. Part of it was this small shed, identical in design to the Chlorination shed at Low Power Test, TAN-643, but slightly larger. It was 9' 4" square and 8 feet high. The walls were vertical metal panels. The roof sloped back moderately from the west wall, which contained the one hollow metal door.

The insulated building contained an electric wall-mounted space heater in one corner, a thermostat, and a concrete pad for mounting the hypochlorinator stand. Louvered vents were in the top of the door and in the east wall. See HAER Photo No. ID $-33-E-314.212$

Water Pump Buildings, TAN-632 and TAN-639

The water supply for the FET came from two wells located northeast of the complex. The pump for each was enclosed in an identical building. These were of the same general design as the others at ANP, differing slightly in dimensions and the size of the flat-roofed projection from the main building.

Each building had a pitched roof, with the gable ends sided with horizontal wood shiplap. Gable facades were east and west. The walls below the gables were pumice block. A 24-inch-throat gravity roof ventilator with chain-operated damper sat atop the 
roof ridge. TAN-632, which served Water Well No. 1, was 12' 8" by 25' 4" long (east/west axis). Its flat-roofed annex was 6 feet wide and contained the hollow metal entry door on the south side. This section contained chlorination equipment and storage for chlorine tanks. The larger room under the gable roof contained a space heater mounted on the wall and the pump, which was to be installed "by government." A double door gave access on the east facade. Concrete pads were poured outside each door.

TAN-639 served Water Well No. 2. This building was smaller, at 10 feet wide by 19' 4" long (north/south axis). The gable ends were on the north and south sides. It had no annex or evident storage space for chlorination equipment. One entry, via double door, was on the east side. In other respects, the design was identical to TAN-632, with pumice block walls, a roof ventilator, and louvered ventilators in at least one wall.213

\section{Exhaust Stack}

While an aircraft was inside the Hanger, the plan was to attach the jet nozzle to a steel duct at the coupling station, filter the exhaust, and send it up a stack located to the rear of the Hangar. The duct, supported by braces on the Hangar floor, would expand from a diameter of 9' 8" to more than 20 feet as it curved upward and entered the stack, a distance of about 130 feet. The ANP program was canceled before the duct, the stack, and several other advanced features of the FET were installed.

\section{PART FOURTEEN}

\section{THE LOSS-OF-FLUID TEST PROGRAM}

Of all the nuclear reactor research conducted anywhere in the United States, studies featuring the total and deliberate destruction of nuclear reactors were unique to the NRTS. NRTS scientists began blowing up reactors in the $1950 \mathrm{~s}$ when they started investigating the types of accidents and malfunctions that might interfere with the safe operation of a reactor.

One possible malfunction was an "excursion," a sudden and unplanned rapid rise in the rate of fission and a concomitant rise in the temperature of the fuel. A series of reactor experiments named "BORAX" (Boiling Water Reactor Experiment) took place at the NRTS in the $1950 \mathrm{~s}$ to dissect in minute detail the process of such events. The only way to discover the operating limits of a reactor was to...push the reactor to its limits. At the time, this was the best way to gather empirical data about excursions and how to prevent them.

The first BORAX test took place in a hole in the ground. The 
reactor was placed in a tank filled with water and open to the sky. Earth shielding surrounded part of the tank. Operators placed a control trailer some distance from the reactor. Before the ultimate destruction of the reactor, they conducted hundreds of data-gathering experiments first.

This simple model was repeated over and over again at the NRTS for another thirty years. As the commercial power industry grew larger and larger, safety questions became more sophisticated. Test facilities became more elaborate and more permanent, but the sequestering of a reactor some safe distance away from a control room became an established pattern for the buildings and facilities erected to conduct destructive tests.

Because of its BORAX experiment, the NRTS was ready with an idea to help the AEC develop standards for the placement of small "swimming pool" reactors in university settings. The AEC knew that if a commercial nuclear power industry were to succeed, it would require well-trained nuclear physicists, engineers, and chemists. The AEC wished to promote nuclear education. But, placing reactors in the hands of graduate students presented risks of its own. The Phillips Petroleum Company, the AEC's operating contractor at the NRTS, proposed to conduct another series of destructive tests. Named SPERT (Special Power Excursion Reactor Test), these answered the necessary questions about university reactors and many others. Eventually, the AEC would be issuing commercial licenses for nuclear power plants. SPERT tests helped define the safety requirements for these reactors.

Beginning in 1963, the AEC achieved its goal of fostering a nuclear power industry, a time sometimes referred to as the "great scale-up." Companies, particularly Westinghouse and General Electric, began to apply for licenses to build power reactors operating at 1,000 megawatts and more. These reactors each used tons of fuel. The size of the plants far exceeded most of the experimental reactors at the NRTS and elsewhere. Most significantly, they were to be located in or near large cities, heavily populated load centers. How could these be engineered to be safe? What conditions and requirements should the AEC place on their operating licenses?

The BORAX and SPERT programs had explored the inner life of reactor fuel as it heated up in an excursion. They had helped discover how to design fuel elements so that the chain reaction shut down naturally if they became too hot. However, the fission products inside the fuel elements continued to generate the heat of radioactive decay. This heat was only five percent to seven percent of the heat from a fissioning reactor. But when the pile of fuel was of commercial scale, this was a substantial amount of heat -- and hazard. 
The new reactors, therefore, had to be engineered not only with coolant to remove the heat of fission and decay heat, but also with backup systems that worked without fail in case the system broke down for some reason. Most commercial reactors were kept cool with pumped water that flowed past the fuel to collect heat. If a pump failed or a pipe broke, what then?

The First LOFT Reactor Concept

An event involving the sudden failure of the coolant to reach the reactor was called a "loss of fluid" or "loss of coolant accident," LOCA, for short. Although power plant designers were proposing a variety of backup systems, the AEC regulators were not convinced that they would work. The systems had not been tested. The many variables interacting in such large reactors might behave quite differently than they did in small-scale reactors.

In 1962, the AEC initiated the Safety Test Engineering Program (STEP) to explore and answer its questions. In 1963, Phillips Petroleum proposed to build a special reactor at the NRTS to explore LOCAs. The AEC agreed. Construction began in 1964. The idea was to place a 50-megawatt reactor -- scaled down proportionately from a commercial-sized plant -- inside a containment building, rig it with instrumentation, operate the reactor, and then test the performance of commercial cooling systems. Phillips called it the Loss of Fluid Test (LOFT) Reactor. In a departure from the usual practice at the NRTS, where reactor components were typically given individual attention, the cooling system components were to come from commercial vendors, the same who supplied General Electric and Westinghouse. Phillips could run each set of components -emergency sprays, pressure suppression devices, and the like -through its paces. In the end, they could simulate a LOCA to "see what happens."214

Commercial reactor vessels and containment buildings also were subjects of doubt. How much heat and pressure could they survive in a LOCA? The Phillips tests would find out how much pressure each could endure as heat and steam built up during a LOCA experiment. After the preliminary tests, the scientists would "break" the coolant pipe, delay inserting the control rods, cut off the cooling water, and disconnect the emergency backup systems. Instrumented in every detail, the reactor would reveal the precise history and nature of the "accident." They would extrapolate the results to larger-scale reactors. The AEC regulators would have empirical data guiding their license requirements. Phillips estimated that the last test would take place in the winter of 1968.215 At least, this was the plan as Phillips engaged Kaiser Engineers to build the containment building. Nuclear engineers began to design the reactor. 
Siting and Layout of the Loss of Fluid Reactor

The LOFT program might be considered the champion of all science programs in adapting and re-using facilities originally designed for previous experiments. Phillips decided to reuse several vacant ANP facilities at Test Area North. The control building (TAN-630) next to the FET hangar was easily adapted for the control building. It supplied that essential accessory for destructive tests, namely a shielded control room at a safe distance from the test.

The LOFT containment building went east of the control room. The hangar was recruited to shelter the power and emergency power system: a diesel generator, banks of wet cell batteries, two motor generator sets, and the requisite switchgear. The tunnels connecting the hangar to the control building could provide LOFT personnel an escape route if ever needed.

Other familiar ANP assets were also reused: the four-rail tracks, the heavy-duty dollies, the shielded locomotive, the turntable, and the movable aluminum building (TAN-624). These transport facilities connected the LOFT site with the analytical capabilities of the A\&M building, TAN-607: the Hot Shop, Cold Shop, Radioactive Materials Laboratory, mechanical shops, and storage pool. LOFT took over the actuator building, TAN-615, as its "clean" area for assembling and storing reactor fuel elements. It used the cells of TAN-633, the Hot Cell Annex for analytical work with hot items.216

The designers envisioned placing the reactor and/or test components on a dolly and moving it back and forth between its containment building and the Hot shop as needed. The movable building would, as it had for the HTRE reactors, shelter against the weather. Since the Hot Shop door was 33 feet high, the dolly and reactor assembly could be no higher than 33 feet.217 Likewise the opening in the containment had to clear 33 feet. See HAER Photo No. ID-33-E-380.

The craft skills accumulated during the ANP days were called upon again. The LOFT program would require remote handling, heavy lifting, decontamination, and instrumentation of every conceivable parameter to record water and reactor behavior during the "accident."

As the program evolved, the STEP program engaged other TAN facilities as well. Scientists required some method of examining the entire range of behavior of the coolant. Under pressure in a reactor (to keep from boiling), a break in a coolant pipe would suddenly release pressure, water would flash to steam, and... what exactly? The dynamics of water as it transitioned between its liquid and gas phases needed closer study. Phillips designed a 
"non-nuclear" reactor called Semiscale. Reactor-like heat could be supplied conventionally; the object of study was the water. Simulated breaks in coolant pipes were called "blowdowns." The old Jet Engine Test pad (TAN-609) once more housed noisy experiments. The cells at the Low Power Test (TAN-640) building likewise saw new duty. Workers began using the new name, WRRTF (Water Reactor Research Test Facility) instead of "Susie" or "Low Power Test Area," and the old ANP names went out of use.

NRTS facilities beyond Test Area North also contributed to this highly interrelated set of programs. Fuel pins went for irradiation to the NRTS Test Reactor Area, where they were subjected to normal and transient conditions. A computerized Fuel Rod Analysis Program was developed with the help of the Power Burst Facility, the most advanced reactor in the SPERT group. All of these complex NRTS resources aimed simply to find out, "Will this emergency cooling system actually cool the fuel elements in a pressurized water reactor?" and "Can computer models predict results?" 218

The LOFT Containment Building (TAN-650)

The Containment Building surrounded the LOFT reactor chamber and the vessel in which it operated. "Containment" was a safety concept aimed at preventing the fission products that had accumulated in reactor fuel from getting into the environment accidentally. The cladding around the fuel element was the first line of defence. The next was the reactor vessel; the dome-topped building was the third. It was to withstand a variety of explosive, pressure-building, and flooding accidents in the event that the first two containers failed. As a reactor headed for destruction, the LOFT system had to imitate accidents, but not their hazardous consequences.

LOFT went under construction in 1964. The reactor was a pressurized water reactor, its engineering providing for five major systems: primary coolant, reactor, blowdown suppression, emergency core cooling, and secondary coolant.

Commercial reactors were built so that each quadrant of fuel within the reactor was cooled independently -- a "four-loop" system. LOFT consisted of one "intact" loop to simulate three unbroken loops in a commercial reactor and another loop to be "broken" for the accident. This loop contained pumps and valves to imitate the sudden blowdown of a pipe break. The "emergency" coolant could be injected at any of several locations, depending on where the "break" had occurred.219 
Figure 16. Configuration of the LOFT reactor for one of its tests. One system represented intact loop, while special valves, and piping were rigged to simulate a "break." Steam and water escaped to a "suppression vessel" to avoid contaminating the floor of the LOFT building. Source: The OECD LOFT Project, p. 54. 
One possible consequence of a loss of coolant was a complete fuel meltdown. The cladding and structural support of the fuel assemblies could collapse at the bottom of the reactor vessel. Absent heat removal, the reactor vessel could likewise melt, and the fission products escape that second container. Continuing, the heat buildup could melt the concrete floor in the basement of the containment building. In that case, the fission products could be dispersed into the environment when the heat reached ground water and turned it explosively to steam.220

The LOFT containment building had two operating levels, the main floor and a basement. The reactor was situated in the middle of a circular, domed building 70 feet in diameter. The basement contained various pumps and equipment rooms. The space directly beneath the reactor was a circular "catch basin" designed to resist a further breach should a fuel melt reach that far. This feature is observed in early construction photos. See HAER Photo No. ID-33-E-355.

In visualizing the architecture of the LOFT building, it is helpful to think of the central dome with a major feature projecting from each of the four cardinal directions. The "front door" with rail access was to the south. To the north was a long narrow wing with five levels above grade (and a broader basement area below). This wing could be thought of as the reactor's coupling station. Penetrations through the dome connected to instrumentation, sampling, electricity, piping, and other equipment here. Early plans referred to it as the "pre-amp" tower. Projecting east was another service wing for receiving highly radioactive liquids. Approximately opposite, the west side featured the airlock door and a corridor to the earth-covered control building next door.221

The reactor entered the chamber through the "railroad door," which weighed 200 tons and was a significant part of the building's total cost. This one-of-a-kind item was engineered to be air tight, necessary to do its part in dome pressure tests and in retaining fission products inside the building. This was achieved with a complex air-inflatable rubber seal.222 The motorized door, curved to match the curve of the building, rolled on rails to open and close. Outside, a metal shroud protected it from the weather. See HAER Photo No. ID-33-E-357.

Inside, two air-lock doors provided a similar air-tight function. One was on the main floor, the other in the basement. The system involved a pair of doors enclosing an air-control chamber between them. The chambers were well-lit and supplied with telephones, ventilation, and pressure equalization.

The containment building was 70 feet in diameter. It had a 
double wall, each made of concrete, poured in place. In the basement, the inside wall was about four feet thick. The air space between it and the outer shell wall was 2.5 feet thick. The outer wall was 2 feet thick. Portions of the wall, such as where it separated equipment service rooms from the reactor, were 7 feet thick.

The LOFT engineers made use of the old ANP shielded roadway . The tunnel extended 700 feet east of the containment dome. This and all entries to the premises, shielded or not, were under administrative control during LOFT operations.223

In adapting the TAN-630 Control Building for LOFT, the engineers found that the ANP earth shielding calculations and other planning would work for LOFT. The upper level contained the control room, visitor center, data rooms, offices, and other support rooms. The ANP's old "emergency kitchen" became a lunchroom for everyday use. The basement, or lower level, housed fire protection equipment, boilers, a diesel electric generator set, electrical and other equipment. Fuel oil pumps for the boilers and generators were separated from the rest of the building by a fire barrier wall. Other fire-rated walls enhanced the safety of operations in the control and visitor rooms.224

The connecting structure between the containment and control buildings was irregular in shape. To the north, the basement level projected 45 feet beyond the north edge of the shielded roadway, or about 79 feet from the outer containment shell. Depending on their particular function, the interior walls of the basement were built of concrete ranging between two feet to four feet thick. This level covered a larger footprint than did the ground floor and other levels above it. At grade level, earth shielding covered part of the basement.

To the east, the waste-related wing projected about 75 feet from the outer shell. It contained four heavily shielded filter chambers, vaults intended to receive air containing fission products and other radioactive particles. See HAER Photo No. ID-33-E-376, where these vaults were numbered B-223, -223A, $-223 \mathrm{~B},-223 \mathrm{C}$, and $-223 \mathrm{D}$.

On the west side, the distance between the outer shell and the control building was about 46 feet. Equipment functions, such as electricity, heating, and some ventilating, that did not involve radioactive liquids or other wastes were located in this area. See HAER Photo No. ID-33-E-373.

In the reactor chamber, four rails from the A\&M turntable crossed the threshold to a set of bumpers arranged for parking the reactor at the center of the chamber. The most visually 
arresting scene inside the chamber (absent the reactor itself)

was the north wall, where a bank of large holes provided pathways for cables to enter the "pre-amp" wing and its rooms 211 and 213. Around the floor near the inner wall was a grated trench for collecting water should any spill during an experiment. The floor also contained two hatches. One was a personnel escape hatch, and the other was in the center to receive certain equipment projecting downward from the reactor dolly. Four hold-downs installed in the floor secured the reactor during experiments. The airlock door for personnel was on the west. People entering the chamber walked through a maze, the major shield wall for which was seven feet thick. The space between the inner and outer shells was filled with removable concrete shielding blocks. Around the top of the chamber, about 62 feet from the floor, a rail accommodated a circular bridge crane.

The pre-amp wing projecting to the north (beyond the holes)was 41 feet wide and about 80 feet long (north/south axis). The concrete walls were 2.5 feet thick. Shielded windows provided a view into rooms 211, the "piping labyrinth," and 213, a "conduit tunnel." The walls surrounding these rooms were concrete four feet thick. See HAER Photo No. ID-33-E-374. This floor contained heat exchange equipment for the reactor's secondary coolant system. 
Figure 17. Views inside pre-amp wing. Spaces were too cramped for HAER photographer to use large-format film. Top: Access door to Room 217, partly closed and open. Sign says, "Notice: No eating, drinking, or smoking in this area." Bottom: Camera within Room 217 faces penetrations in containment dome's north side. Sampling tubes project from opening at left. See HAER Photo No.

ID-33-E-375. Source: INEEL Photo HD-39-12, frames 15, 19, 22. 
Figure 18. Borated water tank, on top floor of pre-amp building. Bottom view shows concrete foundation for tank. See construction views in HAER Photo Nos. ID-33-E-359, -360, and -364. Source: INEEL Photo No. HD-39-12. 
Figure 19. Compressor building, TAN-637, and LOFT stack. Hot liquid waste was piped to $A \& M$ area for treatment. Top: Along road to LOFT, camera facing west. Bottom: Two views of LOFT's metal stack, before demolition. Source: INEEL Photo HD-39-7. 
The pre-amp wing had three additional levels. The first two held cable tray labyrinths for the cables entering from the containment building and shielded accordingly. Work platforms and monorail installations were available for setting up cable bundles and their courses. A tank containing borated water sat on the top floor. When LOFT was first built, this tank was exposed to the sky. Later, a weather enclosure and roof covered it. The tank was a key part of the emergency core cooling system, employed to help quench any reactivity continuing in the core. See HAER Photo Nos. ID-33-E-375 and ID-33-E-377.

The air filter vaults in the eastern projection were covered with hatch covers best seen in aerial photographs. The retaining wall around them was about four feet high. The air to be filtered came from a duct that exited the reactor chamber and ran down the outer wall of the building. The duct was sheltered from the weather by a corrugated metal shroud not unlike the one protecting the door in front. Should someone have to examine or repair the duct, access was via ladders and platforms inside the metal shroud. See HAER Photo No. ID-33-E-376.

The foundation of the LOFT reactor chamber consisted of heavily reinforced concrete. In some areas, such as directly below the reactor, it was as much as 48 feet thick.

The domed roof of the containment building was made of steel. Its tangent with the walls was just above the bridge crane rails. The dome center rose another 35 feet to its apex. See HAER Photo No. ID-33-E-376. Outside of the dome, a platform on the apex could be reached by a ladder and "bosun's chair." An alarm siren was located here. See HAER Photo No. ID-33-E-377.

LOFT Adapts other FET Support Buildings

Other ANP structures were revitalized for LOFT. The water storage system used the water tank (TAN-733) located several hundred feet east of the shielded roadway entrance. The tank building TAN-632 housed the well and pump for Well No. 1. Well No. 2 pumps were in TAN-639. Closer and just south of the LOFT control room, tank building TAN-631 stored two demineralized water tanks and instrument air.

New buildings were required to handle liquid and gaseous wastes. Tank building TAN-626 contained a holding tank to store radioactive liquids produced during operations and blowdown tests. After an experiment, the wastes were pumped from the tank and sent elsewhere at NRTS for processing. A disposal pond was used for low-level wastes. An exhaust stack and a small monitoring shack took ventilated air likely to contain radioactivity. The stack was 150 feet east of the reactor building, and at 150 feet high, tall enough to help disperse 
contaminants. An injection well disposed of "cold" wastes.225 See HAER Photo No. ID-33-E-367 for an overall aerial view.

Semiscale

Kaiser Engineers completed the LOFT containment building after 1970. But a LOFT reactor was nowhere in sight. Events far beyond Idaho had overwhelmed Phillips' early goals for conducting LOFT experiments by 1968. Ideas had changed about the reactor, and ideas about the proposed experiments had changed, too.

The new commercial reactors began to use fuel clad in a material known as zircaloy instead of stainless steel. In 1965, Phillips had to acknowledge this change in order to keep the LOFT reactor consistent with commercial products. It was no small thing, as reactor designers had to re-evaluate the safe operating parameters of the LOFT reactor and adjust accordingly. Producing new safety reports and procedures delayed the effective start date for the project.

As the inventory of large commercial reactors grew throughout the 1960s, the regulatory staff at the AEC began to doubt that Phillips' LOFT program would produce useful information about large-scale engineered systems. They were not sure that the small LOFT reactor test results could meaningfully be applied to large commercial systems. The matter was debatable, and the debate wore on for quite some time without coming to a definite conclusion.226

Milton Shaw, AEC director of Reactor Development and Technology, who had been instrumental in canceling the EBOR project, also had doubts about the LOFT reactor. He feared that quality and performance standards for reactor components, if weak, could result in test results that could neither be replicated nor relied upon. In 1967, he ordered that design work on the reactor be suspended in order to "regroup and do the job right."227 Further, he was not convinced that a detailed investigation into reactor meltdowns (the so-called "China Syndrome") was a useful effort. Resources, he felt, should go into the engineering of foolproof preventatives. Funds for LOFT shriveled up. LOFT employees were laid off. The containment building sat empty.

Meanwhile, using what resources they could pull together, managers at the NRTS developed computer models (called codes) predicting the behavior of coolant during a LOCA. These required some sort of empirical validation. Repeated iterations comparing Semiscale blowdown test results with prior predictions produced constantly more accurate codes. Semiscale tests conducted at the Low Power Test area between 1970 and 1971 demonstrated that after certain types of accidents, steam pressure in the coolant pipes 
prevented emergency water from entering the core to cool it.

The test findings challenged the then-current belief that certain emergency systems were adequate. Margins of safety that had been assumed would now need to be revised. The issue was highly controversial because it meant that commercial licenses would be more costly to obtain. Nevertheless, after the AEC held hearings on the matter, it adopted a more stringent set of "interim criteria" for emergency systems.228

Thus, the non-nuclear semiscale tests had a significant impact on reactor safety long before the LOFT building had found a new mission.

A New Mission for LOFT

New management arrived at the AEC in 1974. Dixie Lee Ray, the new chair of the AEC, removed safety research from the control of Milton Shaw. Money for LOFT began to flow. It had become clear that merely testing off-the-shelf reactor components and then destroying the reactor was too limited a mission for LOFT. The program was re-directed so that the reactor would be a research tool capable of simulating many LOCAs, not just one.

To this end, LOFT engineers refined the reactor's water management system substantially. To avoid flooding and contaminating the reactor chamber repeatedly, they designed a special holding tank for blowdown water. When the coolant loop "broke," water would flow into this tank without damaging the reactor. Some of the valves and pumps were scrounged from the N.S. Savannah, the Maritime Administration's demonstration merchant ship, at that time being scrapped.229 The blowdown tank and its elaborate piping was in the reactor chamber.

The introduction of the blowdown tank and the complexity of the piping and other systems around the reactor, which had to be well anchored, changed earlier plans to move the reactor back and forth to the A\&M. The reactor was larger than the one initially planned, and the piping and other systems did not lend themselves to easy disconnects. Once it began operating, the reactor never moved outside the containment building. The mobile aluminum building, which had been parked in front of the door, acted as a kind of sheltered vestibule, and remained in place until it was schedule for demolition in the general "accelerated cleanup."230

The first nuclear test took place on December 10, 1978. It simulated a "double-ended guillotine break." Coolant flooded from both ends of a suddenly "broken" pipe. A major purpose of the test was to compare actual results with the predictions of the computer codes. The codes had predicted, among other things, that the core would heat up to a temperature of 1,350 degrees F., and 
that the emergency cooling system would become effective within 90 seconds of the break. The system performed better than the predictions: coolant arrived within 44 seconds, and the temperature of the core rose no higher than 1,000 degrees F.231

Plans continued for more tests. Then on March 28, 1979, a loss of coolant accident occurred at the Three Mile Island (TMI) nuclear power plant (Unit No. 2) in Pennsylvania. INEL scientists became involved when it was feared that chemical reactions inside the reactor were creating hydrogen gas with the potential to explode and blow open the containment building. Semiscale was quickly modified to replicate the known situation at TMI-2. A test was run, and INEL scientists concluded that a hydrogen explosion was unlikely, a finding that relieved TMI operators (and the country) of considerable anxiety.232

In the lexicon of reactor coolant accidents, the TMI-2 event was regarded as a "small" leak because the initial cause had been a stuck pressure-relief valve. The LOFT and Semiscale facilities immediately turned to the problem of analyzing such "small" events in a variety of accident scenarios. The objective was the same as before, to develop and verify computer codes with accurate predictive power. By the end of 1980, LOFT managers prepared to conduct a series of tests to simulate the TMI-2 accident. These tests were initially sponsored and financed by the Nuclear Regulatory Commission, which since 1974 had been an agency independent from the AEC, since named the Department of Energy. Twenty-six nuclear tests were run.233

The test results were of great interest to nuclear power utility companies all over the world. In 1983, sponsorship of LOFT experiments shifted to a group of ten countries organized as the Organization of Economic Cooperation and Development. They planned a series of eight final LOFT tests, which concluded in 1985. The first six focused on thermal-hydraulic issues. None of these produced core temperatures hot enough to rupture the cladding around the fuel. The last two tests modeled this possibility, exploring the path of release for the fission products that would leach into the coolant fluid. The last test was deliberately severe, completely melting the fuel bundle inside the LOFT reactor. The post-test analysis traced the movement of the fission products that had escaped in the melt. Scientists concluded that the worst scenarios that had been imagined for the China syndrome were unlikely.234

The Significance of LOFT

The Department of Energy (DOE) decommissioned the LOFT facility in 1986, a procedure that had risen in cost because the final test needed substantial cleanup. The OECD extended its own program through 1989 to study the melted LOFT fuel and test 
assembly in minute detail, aiming for as complete an understanding as possible of the fuel-melt event. The study helped interpret the TMI-2 accident as well.235

LOFT tests improved the conformity between computer codes and empirical evidence. Its accident scenarios, many inspired by the TMI-2 accident, revealed where the codes needed more refinement. The simulations also helped determine how to recover a reactor to a safe condition immediately after an accident.

The STEP/LOFT program informed the licensing requirements for commercial reactors, not only in the United States, but in many other countries (not including the Soviet Union). It relieved certain overly conservative assumptions that had been established in the early years of the nuclear power industry. The other side of that coin was the technical improvements it had inspired in safety engineering.

One of the participants in the OECD/LOFT program wrote:

The fact that it was possible to conduct the experiments, particularly the last and most severe, in a controlled manner is a measure of the understanding of accident behavior which now exists.236

With LOFT, the NRTS/INEL ended its honorable history in the destruction of nuclear reactors. The sequence from BORAX through SPERT (including the Power Burst Reactor) and LOFT had created a body of knowledge about the most intimate processes of change within a reactor due to temperature transients and loss of coolant. It had conducted these tests without any loss of life or undue hazards to downwind populations. The nuclear reactor industry in the United States has an operational safety record unmatched by any other electric utility.

\section{PART FIETEEN}

\section{CONCLUSION: TEST AREA NORTH AFTER LOFT}

The LOFT reactor was the last reactor built at the INEEL. It symbolizes the end of the historically significant "reactor testing era" in the United States. The Idaho site had birthed the commercial power industry in 1951 with the electric lighting of four bulbs at Experimental Breeder Reactor-1. It seems fitting that the "last" reactor was one that passed a baton from empirical testing to computer safety modeling. Because of the former, the latter was made feasible. Because of the latter, the former is no longer deemed necessary. 
Three Mile Island contributed one final legacy to Test Area North. After INEL scientists predicted the condition of the melted fuel in the TMI-2 reactor vessel (using the Power Burst Facility, elsewhere at the INEEL), DOE decided to send the fuel debris to the A\&M, TAN-607, for analysis and storage.

This undertaking spawned a number of INEEL activities, including accessing the debris from the TMI-2 reactor vessel (with a "core bore" drill devised at INEL), performing cask-handling tests, transporting the debris to Idaho, examining it, and storing it in the A\&M fuel storage pool. The project took ten years. It was done safely. The last shipment arrived at TAN in 1990. After negotiation with the state of Idaho, the fuel has recently been moved to a dry storage facility at INTEC, a move that contributed to the diminished mission for Test Area North.

The TMI-2 activities made use of the many and varied laboratories and buildings built originally for manhandling a nuclear airplane. They had been designed for the heavy work of developing the propulsion plant. Those heavy-enough requirements had been made heavier still by the shielding safeguards brought to the enterprise by mobile nuclear reactors and their offspring: spent fuel, fission products, and wastes of all kinds.

The ANP shield designs and remote-control innovations were sound enough to be relied on well beyond 1961 as other programs adapted them to new projects. The cells of the Low Power Test facility were home to a series of critical experiment reactors. (See Appendix E for a list of reactors that operated at TAN.) The Shield Test Facility pools were drained for the sake of EBOR. The IET revived for the Space Program. LOFT made use of the earth-covered control room next to the Hanger -- and the Hangar itself.

A variety of non-nuclear programs came and went in the other facilities, but the heart of TAN has always been the A\&M building, TAN-607. The Hot Shop was apparently the largest hot cell in the United States. Despite occasional slow times, TAN-607 has always enjoyed "beneficial use." Despite slow times, it has never closed, stood vacant, or been without a mission. Some activity has always required one of its shops, shielded for high, moderate, or no radioactivity.

The significance of the ANP program was discussed more fully in HAER Report ID-33-A. The airplane was never built, but later generations with environmental and anti-nuclear sensibilities now wonder about the nuclear bomber promoters and ask "What were they thinking?" In the 1950's Cold War era, "they" were thinking about the possible consequences if the enemy obtained the weapon first. Or was it that simple? After a world war during which the United 
States government financed private industry to produce the atomic bomb, private industry continued to have a stake in the arms race. Historians will be arguing the true nature of the arms race for a long time to come: Was it patriotic self-defence? or the self-interested manipulation by large well-connected corporate interests to obtain lucrative government contracts?

As an architectural remnant of the period, Test Area North is a tribute to the ingenuity and innovation of its creators. Shielding was their theme and urgent necessity. In confronting for the first time the problem of mobile reactors of enormous size and scope -- under test -- they produced a tour-de-force in shield techniques: high-density concretes, viewing windows, "swimming pools," labyrinthine mazes, shadow shields, blast doors, Z-shaped conduit pathways, remote manipulators of all kinds, blankets of earth, glove boxes, exclusion fences, shielded locomotive, shielded escape hatches, shielded tunnels, shielded driveways, "quick connect" coupling stations, shielded periscopes and cameras, transport casks, positive/negative air pressure; not to mention the exploitation of open space and distance in the desert for radioactive attenuation, and layered combinations of lead, steel, aluminum, air, water, concrete, and earth.

Their architectural creations were, perforce, the first of their kind, unique: the IET, the Hot Shop, the Hangar. If their earth-covered control rooms lacked an aesthetic principle, they made up for it in functional elegance.

Had an airplane flown and spawned a successful industry based on nuclear flight, these structures would have become honored vessels of a proud technological history. At the INEEL thus far, only the EBR-1 reactor has enjoyed this kind of recognition: no less a personage than the president of the United States declared EBR-1 a national historical monument. But then, commercial nuclear power became a "winner" in history; the nuclear airplane did not. 
Figure 20. The shielded driveway leading to the Flight Engine Test/LOFT control building. Source: INEEL Photo HD-39-12. 
APPENDIX A

VICINITY MAP: TEST AREA NORTH AT NRTS/INEL/INEEL 


\author{
APPENDIX B-1 \\ GENERAL PLOT PLAN OF TEST AREA NORTH \\ (Including post-ANP area names)
}

WRRTF: Water Reactor Research Test Facility = Low Power Test Area

TSF: Technical Support Facility = Assembly and Maintenance and Administrative Areas

SMC/CTF: Specific Manufacturing Capability (tank armor) and Contained Test Facility = Flight Engine Test/LOFT facility 
APPENDIX B-2

PLOT PLAN FOR IET, 1995 
APPENDIX B-3

PLOT PLAN FOR A\&M AND ADMIN AREAS, 1995 
APPENDIX B-4

PLOT PLAN FOR LOW POWER TEST AREA, 1995 
APPENDIX B-5

PLOT PLAN FOR FET/LOFT AREA, 1995 


\section{APPENDIX C}

HTRE AND RELATED ANP REACTOR TESTS

HTRE Runs Test Location was the IET. Bracketed dates should not be inferred to mean continuous non-stop run during that period.

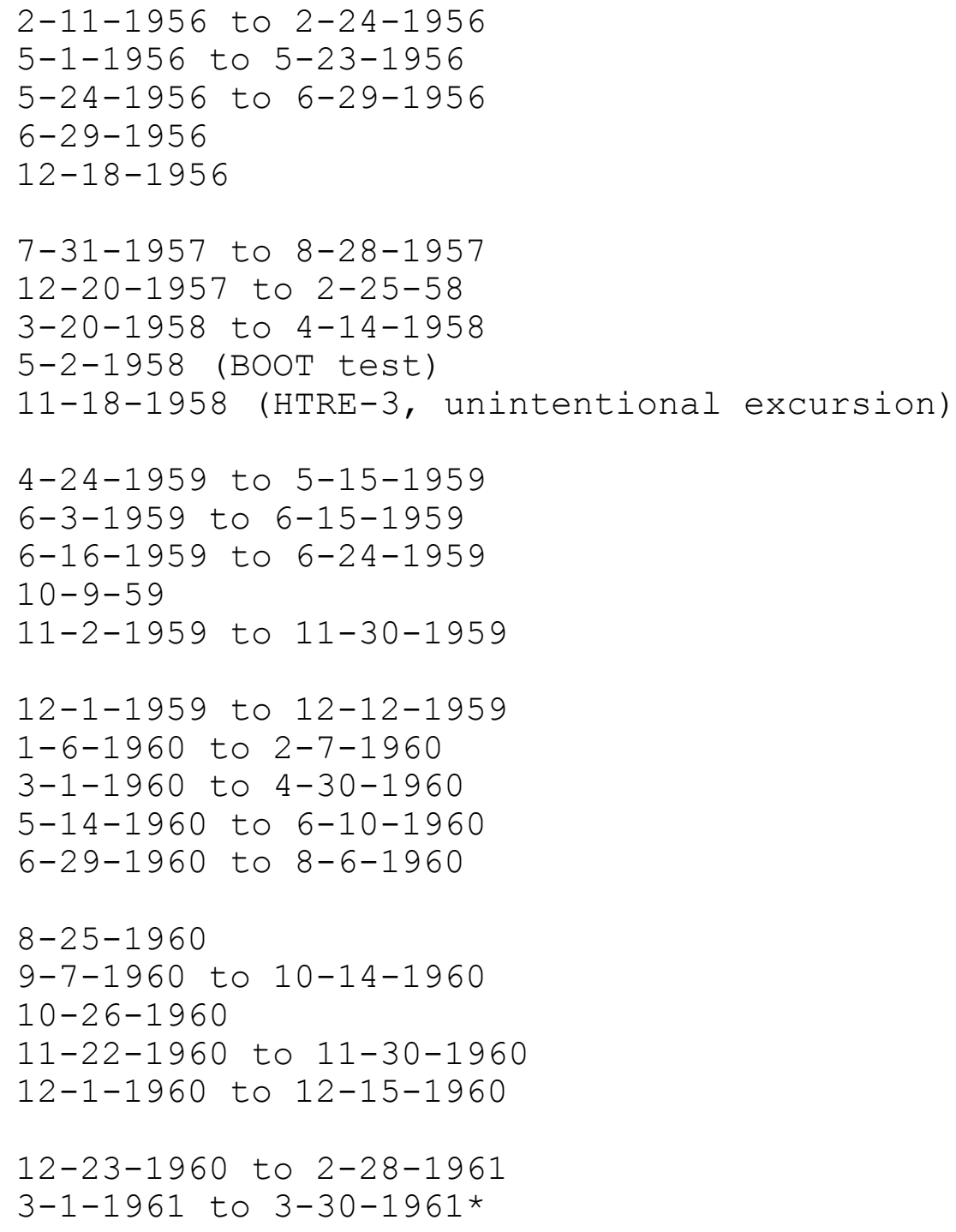

Fuel Element Burn Tests Test location was "Grid III" at the NRTS (not at the IET). These were tests of fuel elements deliberately subjected to fire or other simulated airplane crash disasters.

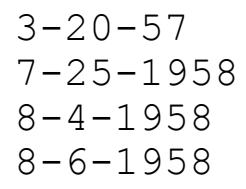


$8-14-1958$

$8-27-1958$

$9-4-1958$

$9-17-1958$

$9-18-1958$

$9-26-1958$

* President John F. Kennedy canceled the ANP program on March 28, 1961. The bracketed date of March 30, 1961, may or may not be accurate.

Sources:

INEL Historical Dose Evaluation, Volume 1, DOE/ID-12119 (Idaho Falls: INEL, 1991), Table A-19, pages A-52 to A-55.

Susan M. Stacy, Proving the Principle, A History of the Idaho National Engineering and Environmental Laboratory (Idaho Falls: Department of Energy, 2000), Chapter 15, "The Triumph of Political Gravity Over Nuclear Flight" for an account of Fuel Element Burn Tests, also known as "Operation Wiener Roast." 
APPENDIX D

LOFT EXPERIMENT PROGRAM 
Susan M. Stacy, Proving the Principle, A History of the Idaho National Engineering and Environmental Laboratory (Idaho Falls: Department of Energy, 2000), p.259-268. 


\section{APPENDIX F}

\section{SHIELDING MATERIALS}

Until the early 1950s, the accumulated technical knowledge of shielding materials and techniques that had been built up during the previous decade resided mainly in the realm of secret documents.

As the AEC considered its goal that the nation develop a nuclear power industry, it took steps to assure that the industry would have trained nuclear engineers. The AEC collaborated with the American Society for Engineering Education to produce unclassified sourcebooks and textbooks.

One of the products of this collaboration was samuel Glasstone's, Principles of Nuclear Reactor Engineering. Much of the information in this book came from lecturers at the Oak Ridge School of Reactor Technology. This book codified for public use the engineering basics as they were understood and employed in the early 1950s.

The following is a brief summary of characteristics of common shielding materials.

\section{$\underline{\text { Lead }}$}

Use: As a gamma shield, it has a high density and high atomic number. Lighter weight than steel or concrete of equal gamma-ray attenuation. Useful for wrapping around a source.

Considerations: If it is close to heat, it might need to be cooled. Should be pure, not scrap. Won't readily activate. When used in bricks, the cracks between the bricks have to be shielded. Should scan for hot spots.

Disadvantages: Expensive, low melting point, soft, low strength, tends to creep. Needs bonding to or reinforcement by steel.

\section{Iron and Steel}

Use: Strong. As neutron shield, can be exposed to high temperatures. Resists radiation damage and activation. Often used in combination with water and/or concrete. Iron ores such as magnetite and iron punchings or shot are mixed with Portland cement to make heavy concretes, which improve gamma attenuation over ordinary concrete. 
Considerations: May be clad in stainless steel, plated, or painted to protect from rusting. Self-supporting, may support other components. Castings and seams of welded plates need inspection for hot spots and flaws.

Disadvantages: A significant source of capture gamma rays and inelastic scattering gamma rays. It needs additional gamma shielding or a thicker shield overall to attenuate gamma rays.

\section{Concrete}

Use: Neutron shield. Concrete contains water, the hydrogen atoms in which slow down neutrons. Is not damaged by radiation.

Considerations: Thinner shields can be made with dense aggregates such as magnetite, limonite iron ore, barytes (barium ore), and iron punchings. As concrete cures and ages, it gradually loses water. Making the shield thicker can compensate for this. Boron can be added to the mix to suppress production of capture gamma rays.

Disadvantages: Low density and low atomic number are drawbacks for gamma shielding. Heavy concrete is expensive to make and to install. High heat can cause cracking.

Note: Ordinary concrete is made from a mixture of Portland cement, coarse aggregate (crushed rock or gravel), sand, and water: 1 part cement, 2 parts sand, 4 parts aggregate, and about 6 gallons of water per 94 pounds of cement.

It is best to cast concrete in one continuous pour, with reinforcing bars and penetrations already in place. If parts must be poured and allowed to set, the join should be rebated to prevent neutron streaming.

$$
\text { Rebated joint: }
$$

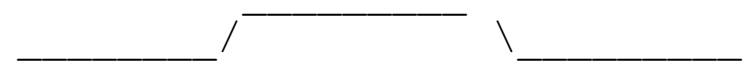

$\underline{\text { Water }}$

Use: An excellent neutron shield because of its high concentration of hydrogen atoms, which absorb neutrons. In sufficient thickness, will attenuate gamma rays. Pure water will not become radioactive.

Considerations: Has relatively low density and low atomic number, which is why water shields must be thick to attenuate gamma rays. Water is transparent and fluid, good for cooling. Impurities in water may activate under radiation and often must be removed. 
Disadvantages: Water containers with excellent leak-proof qualities may be costly. Water is mildly corrosive, adding to cost of containers. Low boiling point precludes use at high temperatures (unless it is pressurized). Impurities in water may need to be removed.

Air and Soil

Use: Air is not a material, but contributes to attenuation due to gradual loss of energy generated by the source. It is a low density mixture of gases, including nitrogen, oxygen, and argon, with traces of water and carbon dioxide.

Soil can shield against radionuclides that are deposited on the surface. As its composition is variable, depth of soil for shield may vary.

Paraffin (organic polyethylene)

Use: Neutron shield. Has higher concentration of hydrogen than water.

Considerations: Can be shaped as sheets, slabs, bars, and pellets. Easy to extrude or mold. Boron can be added to suppress capture-gamma ray production.

Disadvantages: Has very little resistance to heat and radiation. At relatively low temperature, will creep; needs structural support. Combustible.

\section{$\underline{\text { Penetrating a Shield }}$}

Shields may be penetrated by: conduit for electric cables, piping, mechanical devices, holes with removable plugs, tunnels for personnel, collimators, and beam ports. Shield effectiveness is diminished if the material filling a duct is a poorer attenuator (or generates secondary gamma rays) than the bulk of the shield. Air is a poor attenuator. Holes easily destroy the effectiveness of a shield near the penetration.

A straight duct permits line-of-sight exposure: radiation that penetrated the shield can enter the duct; neutrons or primary gamma rays may scatter from the duct wall or generate secondary gamma rays from neutrons incident on the wall.

One way to manage penetrations is to introduce steps or bends to avoid direct streaming of radiation down the duct, and by reinforcing the shield with thicker or more effective material 
around the penetration.

Holes and ports may be closed with plugs or doors. There is usually a gap between the plug and hole due to allowance for thermal expansion, clearance for movement, or manufacturing tolerances. Thus, plug and hole should have at least one step to block line of sight component and reduce radiation streaming down the gap.

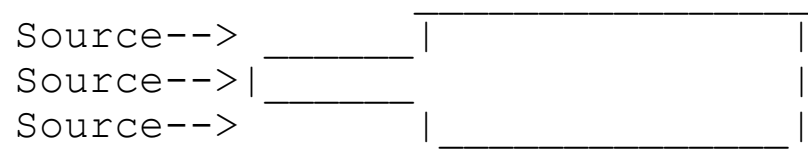
Stepped cylindrical plug (one step)

Some radiation can still stream down the gap, although not in a line-of-sight path. Radiation that bounces along the walls can proceed around the step. Thermal neutrons can produce secondary gamma rays deep within the shield.

When a hole cannot be plugged, such as in a gas-filled cooling pipe or personnel tunnel, the duct should be constructed with one (L-shaped duct) or more bends in bent ducts, labyrinths, or mazes. Three-legged ducts (U-shaped mazes or Z shaped ducts) can do even better.

Electrical cables and small diameter cooling pipes are often twisted into a helix. Diameter of the helix should be a few times the diameter of the conduit or pipe. Pitch should be fairly large to facilitate pulling the cable or reducing pressure drop in the pipe, and to minimize volume of shield material replaced.

Sources:

A. Edward Profio. Radiation Shielding and Dosimetry. New York: John Wiley and Sons, 1979. See pages 409-421; 467-468.

Samuel Glasstone. Principles of Nuclear Reactor Engineering. Princeton: D. Van Nostrand Co., 1955. See Chapter X, "Shielding of Nuclear Reactor Systems." 


\section{BIBLIOGRAPHY}

\section{APEX and Unauthored Reports}

630A Maritime Nuclear Steam Generator Progress Report No. 7, GEMP-274. Cincinnati: GE Nuclear Materials and Propulsion Operation, March 1964.

A Historical Brief of the LOFT Reactor Project at the Idaho National Engineering Laboratory. Idaho Falls: Aerojet Nuclear Company, 1975.

Aircraft Gas Turbine Department, General Electric Company. Engineering Progress Report No. 2, October 1, 1951 December 31, 1951, DC-51-12-25. Lockland, Ohio: General Electric, 1952 .

Aircraft Gas Turbine Department, General Electric Company. Engineering Progress Report No. 5, September 1952, APEX-5. Lockland, Ohio: General Electric, 1952.

Aircraft Gas Turbine Department, General Electric Company. Engineering Progress Report No. 7, January 1, 1953 - March 31, 1953, APEX-7. Cincinnati: General Electric, 1953.

Aircraft Gas Turbine Department, General Electric Company. Engineering Progress Report No. 11, January 1, 1954 - March 31, 1954, APEX-11. Cincinnati: General Electric, 1954.

Atomic Products Division, General Electric Company. Engineering Progress Report No. 13, July 1, 1954 - September 30, 1954, APEX-13. Cincinnati: General Electric, 1954.

Atomic Products Division, General Electric Company. Engineering Progress Report No. 14, October 1, 1954 - December 31, 1954, APEX-14. Cincinnati: General Electric, 1954.

Atomic Products Division, General Electric Company. Engineering Progress Report No. 15, January 1, 1955 - March 31, 1955, APEX-15. Cincinnati: General Electric, 1955.

Atomic Products Division, General Electric Company. Engineering Progress Report No. 16, April 1 - June 30, 1955, APEX-16. Cincinnati: General Electric, 1955.

Atomic Products Division, General Electric Company. Engineering Progress Report No. 17, July 1, 1955 - September 30, 1955, APEX-17. Cincinnati: General Electric, 1955. 
Atomic Products Division, General Electric Company. Engineering Progress Report No. 18, December 1955, APEX-18. Cincinnati: General Electric, 1955.

Atomic Products Division, General Electric Company. Engineering Progress Report No. 19, March 1956, APEX-19. Cincinnati: General Electric, 1956.

Atomic Products Division, General Electric Company. Engineering Progress Report No. 20, April 1, 1956 - June 30, 1956, APEX-20. Cincinnati: General Electric, 1956.

Atomic Products Division, General Electric Company. Engineering Progress Report No. 22, December 1956, APEX-22. Cincinnati: General Electric, 1956.

Aircraft Gas Turbine Department, General Electric Company. Nuclear Power Plant Testing in the IET, APEX-131. Evendale, Ohio: ANPP, 1953.

Brief History of the SNAPTRAN Program. No. pub. information, but found at INEEL Records Storage Warehouse, Box 157081, file "SNAP."

The OECD/LOFT Project, Achievements and Significant Results. Proceedings of an Open Forum sponsored by the OECD Nuclear Energy Agency, May 9-11, Madrid, Spain.

U.S. Department of Commerce, National Bureau of Standards. Permissible Dose from External Sources of Ionizing Radiation, Recommendations of the U.S. National Committee on Radiation Protection, Handbook 59. Washington, D.C.: Superintendent of Documents, 1954.

U.S. Department of Energy Idaho Operations Office. Environmental Management Performance Management Plan for Accelerating Cleanup of the Idaho National Engineering and Environmental Laboratory, DOE/ID-11006. Idaho Falls: DOE/ID, July 2002.

U.S. Department of Energy Idaho Operations Office. Comprehensive Facility and Land Use Plan, DOE/ID-10514. Idaho Falls: DOE/ID, 1996.

Decontamination and Dismantlement of the TAN-615 Assembly and Maintenance Building, HAD-164. Idaho Falls: INEEL, 2001.

Books, Articles, and Authored Reports

Adams, J.P., D.L. Batt, V.T. Berta. "Influence of LOFT PWR 
Transient Simulations on Thermal-Hydraulic Aspects of Commercial PWR Safety." Nuclear Safety 27 (April-June 1986), p. 179-192.

Arrowrock Group, Inc. The Idaho National Engineering and Environmental Laboratory, A Historical Context and Assessment, Narrative and History, INEEL/EXT-97-01021. Idaho Falls: DOE/ID, November 2003.

Blevins, D.J, et al. Flight Engine Test Facility Design Criteria, APEX-225. Idaho Falls: General Electric, 1955.

Braun, Julie. INEEL Historic Architectural Properties Management Plan for U.S. Department of Energy, Idaho Operations Office, INEEL/EXT-02-1338. Idaho Falls: Bechtel BWXT Idaho, LLC, October 2003 .

Burdge, L.F. LOFT Integral Test System, Final Safety Analysis Report, Revision 1, volume 2 of 3, LOFT-FSAR-V2-R 1. Idaho Falls: EG\&G Idaho, Inc., August 1977.

Corbin, Jr., Austin. Nuclear Aspects of the Remote Site Facilities, APEX-105. ANPP, 1920.

Corliss, William R. SNAP Nuclear Reactors. Washington, D.C.: US $\mathrm{AEC}, 1966$.

Crease, Robert P. Making Physics, A Biography of Brookhaven National Laboratory, 1946-1972. Chicago: University of Chicago Press, 1999.

Deutsch, Morris, R.L. Nace, and P.T. Voegeli. Geology, Ground Water, and Waste-Disposal at the Aircraft Nuclear Propulsion Project Site, National Reactor Testing Station, Idaho, IDO-22023-USGS. Boise: U.S. Department of the Interior, Geological Survey, 1952 .

Devens, Fred. Data Report D102 A2 Power Plant Testing, IET 13, DC-59-4-710. Idaho Test Station: Test Engineering, 1959.

Donnelly, Warren H. Nuclear Power and Merchant Shipping. Washington, D.C.: US AEC, 1965.

Fell, J., and S.M. Modro. An Account of the OECD LOFT Project, OECD LOFT-T-3907. Idaho Falls: OECD LOFT, May 1990.

Gale, L.G. PREPP Deactivation Plan, WM-PD-90-015. Idaho Falls: $E G \& G, 1990$.

Gamertsfelder, C.C. The Remote Site Particle Problem, APEX-124. 
ANPP. No date, but circa 1953.

Gilliland, D.L., J.F. Kunze. Addendum to Hazard's [sic] Summary Report for Susie Reactor, Report No. XDCL 61-5-718 and APEX-459-1. Idaho Falls: GE, 1961.

Glasstone, Samuel. Principles of Nuclear Reactor Engineering. Princeton, N.J.: D. Van Norstrand, 1955.

Glasstone, Samuel. Sourcebook on Atomic Energy. Princeton, N.J.: D. Van Norstrand, 1967), p. 752.

Haley, D.J., and T.G. Hedahl. Safety Analysis for the Process Experimental Pilot Plant, PG-WM-84-019. Idaho Falls: EG\&G, 1984 .

Hansjergen, J.F, and R.E. Layman. Shield Test Pool Facility, Susie Reactor Operation Progress Report, June 15, 1961 through August 6, 1961, XDCL-61-9-700. Idaho Falls: GE, August 1961. Subsequent reports with similar titles include the XDCL series 61-10-700, 61-11-706, 61-11-708, 61-12-708, and 62-2-708.

Hecht, Selig. Explaining the Atom. New York: Viking Press, 1947.

Heidkamp, H.A. Decontamination and Dismantlement Plan for the TAN-615 Assembly and Maintenance Building, INEEL/EXT-2001-01467, Revision 1. Idaho Falls: Bechtel BWXT Idaho, LLC, May 2002 .

Hewlett, Richard G., and Francis Duncan. Atomic Shield, 1947/1952, Volume II of a History of the United States Atomic Energy Commission. University Park: Pennsylvania State University Press, 1969.

Hicks, D., and K. Sato. "Contributions of the OECD/LOFT Project to Nuclear Safety," in Proceedings of an Open Forum sponsored by the OECD Nuclear Energy Agency with the support of the OECD/LOFT Spanish Consortium, May 9-11, 190. Madrid, Spain: OECD Nuclear Energy Agency, 1990.

Hoefer, J.A. Hoefer. Summary Hazards Report For Critical Experiments with the HOTCE Reactor, APEX-345. Evendale: GE Atomic Products Division, no date.

Hogerton, John F. The Atomic Energy Deskbook. New York: Reinhold Publishing Corporation, 1963.

Holl, Jack M., Roger M. Anders, and Alice L. Buck. United States Civilian Nuclear Power Policy, 1954-1984: A Summary History 
DOE/MA-0152. Washington, D.C.: U.S. Department of Energy History Division, 1986.

Jones, L. Design Criteria, Shield Test Facility, Report No. APEX-217. Idaho Falls: GE, 1956.

Kaminsky, J.F. Remedial Investigation Final Report with Addenda, EGG-ER-10643. Idaho Falls: EGG, 1994 .

Langford, J.E. Design Review Plan for the Process Experimental Pilot Plant (PREPP), EGG-TF-6057. Idaho Falls: EG\&G, 1982.

Lopez, Steve L. Final Report for the Decontamination and Decommissioning of the Test Area North-615, INEEL/EXT-02-01118. Idaho Falls: Bechtel BWXT Idaho, LLC, 2003 .

Luke, C.W., D.L. Gilliland, R.E. Baker. Hazards Summary Report for Susie Reactor, Report No. APEX-459.Cincinnati: GE Atomic Products Division, 1959.

McCartney, Layton. Friends in High Places, The Bechtel Story, The Most Secret Corporation and How it Engineering the World. New York: Simon and Schuster, 1988.

McCracken, Samuel. The War Against the Atom. New York: Basic Books, 1982 .

McCullough, C. Rogers, in Safety Aspects of Nuclear Reactors. Princeton: D. Van Norstrand, 1957.

Marceau, Thomas E., et al. Hanford Site Historic District, History of the Plutonium Production Facilities, 1943-1990, DOE/RL-97-1047. Richland, Washington: Battelle Press, Hanford Cultural and Historic Resources Program, US Department of Energy, 2003.

Nace, R.L. Memorandum: Water Supply and Waste Disposal at Proposed ANPR Site, National Reactor Testing Station, Idaho, IDO-22021-USGS. Boise: U.S. Department of the Interior, Geological Survey, 1952 .

Nace, R.L., et al. Physical Environment of the National Reactor Testing Station, Idaho-- A Summary, US Geological Survey

Professional Paper 725-A. Washington, D.C.: US AEC and USGS, 1972 .

Ralph M. Parsons Company. Airport Facilities: Qualifications, Experience. Los Angeles: Ralph M. Parsons Company, no date. 
Ralph M. Parsons Company. ANP Facilities. Los Angeles: Ralph M. Parsons Company, no date, but circa 1958.

Ramos, Amadeo. A Proposed Hazard Classification for the PM-2A Tank Remedial Action at the INEEL, ICP/CON-04-00162. Idaho Falls: DOE/ID, 2004 .

Profio, A. Edward. Radiation Shielding and Dosimetry. New York: John Wiley and Sons, 1979.

Scheider, walter. A Serious but not Ponderous book About Nuclear Energy. Ann Arbor, Michigan: Cavendish Press, 2001.

Schmid, Loren C. Critical Assemblies and Reactor Research. New York: John Wiley and Sons, 1971.

Spofford, N.P. Discussion of Criteria for IET Exhaust Gas System, XDC-53-12-74. Cincinnati: GE ANPP, 1953.

Stacy, Susan M. Idaho National Engineering Laboratory, Army Reactor Experimental Area, Historic American Engineering Record ID-33-D. Idaho Falls: Lockheed Martin Idaho Corporation, 1998.

Stacy, Susan M. Idaho National Engineering Laboratory, Advanced Reentry Vehicle Fuzing System, Historic American Engineering Record ID-33-B. Idaho Falls: Lockheed Martin Idaho Corporation, 1997.

Stacy, Susan M. Idaho National Engineering Laboratory, Old Waste Calcining Facility, Historic American Engineering Record ID-33-C. Idaho Falls: Lockheed Martin Idaho Corporation, 1997 .

Stacy, Susan M. Idaho National Engineering Laboratory, Test Area North, Hangar 629, Historical American Engineering Record ID-33-A. Idaho Falls: Lockheed Martin Idaho Corporation, 1995. (Originally numbered ID-32-A.)

Stacy, Susan M. Proving the Principle, A History of the Idaho National Engineering and Environmental Laboratory. Idaho Falls: DOE, 2001.

Stepp, Ann. The Story of Radioactivity. Irvington-on- Hudson, New York: Harvey House, Inc., 1971.

Thornton, G., and A.J. Rothstein. Comprehensive Technical Report, GE Direct-Air-Cycle ANP Program, Program Summary and References, APEX-901. Cincinnati: GE, 1962. 
Tierney, John. "Take the A-Plane: The Nuclear Bird that Never Flew." Science 823 (Jan-Feb, No. 1).

Waage, J.M. Preliminary Safety Analysis Report, LOFT Facility, IDO-16981. Idaho Falls: Phillips Petroleum Co., April 1964.

Walker, J. Samuel. Permissible Dose, A History of Radiation Protection in the Twentieth Century. Berkeley: University of California Press, 2000.

Walsh, W.P. Test Program and Procedures for STF Program A, Initial Organic Reactor Material Irradiation on Susie Reactor North Face, Report No. DC-61-7-706. Idaho Falls: GE Nuclear Materials and Propulsion Operation, 1961.

Williams, G.R. Design Criteria for the Low Power Test Facility, APEX-227. ANPP Idaho Test Station: GE, 1956.

\section{Other Sources}

Sherman McGarry. Manuscript notes with photos, located at Cultural Resource Office, INEEL, Idaho Falls.

Thumbnail Sketch, several editions as noted.

Interviews and personal communications:

Leo Barbour, Parsons

John Commander, INEEL

John DeClue, Parsons

Elden Fisher, Parsons

(The late) John Horan, INEEL

Jay Kunze, GE/INEEL

Richard Meservey, INEEL

Kevin Streeper, INEEL 
1 For a fuller account of the Naval Proving Ground and the creation of the NRTS, see Susan M. Stacy, Proving the Principle, A History of the Idaho National Engineering and Environmental Laboratory, 1949-1999 (Idaho Falls: DOE Idaho Operations Office, 2000), chapters two through five. Hereafter cited as Proving the Principle.

2 The name is scheduled to change to "Idaho National Laboratory" in February 2005.

3 For an account of the AEC's perspective on the creation of the NRTS, see Richard G. Hewlett and Francis Duncan, Atomic Shield, 1947/1952, Volume II of a History of the United States Atomic Energy Commission (University Park: Pennsylvania State University Press, 1969), p. 199-206, 210-11, 216-19. Hereafter cited as Atomic Shield.

4 The name "Test Area North" came into use in 1961, after President John F. Kennedy canceled the ANP program. For reader convenience, this report will use this name or "ANP area" throughout. See Sherman C. McGarry manuscript archived at INEEL Cultural Resource Department (Braun Collection), Idaho Falls, notes to "Picture 5." Hereafter cited as "McGarry notes."

5 Hewlett and Duncan, Atomic Shield, p. 496.

6 J.F. Kaminsky, Remedial Investigation Final Report with Addenda, EGG-ER-10643 (Idaho Falls: EGG, 1994), p. 2-3.

7 John Horan, telephone interview by Susan M. Stacy, July 29, 1997 .

8 Morris Deutsch, R.L. Nace, and P.T. Voegeli, Geology, Ground-Water, and Waste-Disposal at the Aircraft Nuclear Propulsion Project Site, National Reactor Testing Station, Idaho, ID)-22023-USGS (Boise: U.S. Department of the Interior, Geological Survey, 1952), p. 7; see also Idaho National Engineering Laboratory, Comprehensive Facility and Land Use Plan, DOE/ID-10514 (Idaho Falls: DOE/ID, 1996), p. 45.

9 Leo H. Barbour, telephone interview with Susan stacy on March 24, 2004. Barbour worked for Ralph M. Parsons Company and designed exterior features at the Flight Engine Test area.

10 Deutsch et al, Geology, p. 7-8.

11 Raymond L. Nace, Physical Environment of the National Reactor Testing Station, Idaho -- A Summary (Washington, D.C.: US $\mathrm{AEC}, 1972), \mathrm{P} . \mathrm{A}-14$. 
12 General Electric progress reports occasionally refer to an "Air Force Master Plan" in describing ANP facility clusters. To date, a copy of this document has not been located.

13 U.S. Department of Energy Idaho Operations Office, Environmental Management Performance Management Plan for Accelerating Cleanup of the Idaho National Engineering and Environmental Laboratory, DOE/ID-11006 (Idaho Falls: DOE/ID, July $2002), \mathrm{p} . \mathrm{i}, 21-23$.

14 The Arrowrock Group, Inc., The Idaho National Engineering and Environmental Laboratory, A Historical Context and Assessment, Narrative and History, INEEL/EXT-97-01021 (Revision 1) (Idaho Falls: DOE/ID, November 17, 2003).

15 Julie B. Braun, INEEL Historic Architectural Properties Management Plan for U.S. Department of Energy, Idaho Operations Office, INEEL/EXT-02-1338 (Idaho Falls: Bechtel BWXT Idaho, LLC, October 2003), p.7-8, 16-17; Letter no. CCN 47704: "Interim Programmatic Agreement and Memoranda of Agreement for DD\&D at the INEEL," January 30, 2004, enclosure No. 4, "TAN Memorandum of Agreement between US DOE/ID and Idaho SHPO."

16 Susan M. Stacy, Idaho National Engineering Laboratory, Test Area North, Hangar 629, Historical American Engineering Record ID-33-A (Idaho Falls: Lockheed Martin Idaho Corporation, 1995.) Originally numbered ID-32-A. Three other HAERs have been prepared for INEEL facilities: the Old Waste Calcining Facility, the Advanced Reentry Vehicle Fuzing System bunker, and the Army Reactors Area. See bibliography.

17 Quoted by Kevin Richert in "Original AEC Site Spawned Eastern Idaho's 'Gold Rush,'" (Idaho Falls) Post Register, May $15,1994, \mathrm{p} . \mathrm{H}-20$.

18 Ann Stepp, The Story of Radioactivity (Irvington-onHudson, New York: Harvey House, Inc., 1971), p. 17-21.

19 Energy does not result from the splitting of the bonds within a uranium nucleus, but from the formation of the bonds bringing together the daughter nuclei. "Unused" mass takes on the properties of energy. See Walter Scheider, A Serious but not Ponderous book About Nuclear Energy (Ann Arbor, Michigan: Cavendish Press, 2001), p. 3-13.

20 For an excellent description of the threats of radiation to the human body, see J. Samuel Walker, Permissible Dose, A History of Radiation Protection in the Twentieth Century (Berkeley: University of California Press, 2000), p. 5. 
21 The intensity of radiation received from a point source such as a reactor is inversely proportional to the square of the distance between the source and the receiver. Increasing the distance by a factor of two, for example, decreases the radiation received to one fourth. A three-fold increase in distance decreases radiation intensity to one ninth. See Samuel Glasstone, Sourcebook on Atomic Energy (Princeton, N.J.: D. Van Norstrand, $1967), \mathrm{p} .752$.

22 Stepp, The Story of Radioactivity, p. 24.

23 "Architect/engineers" design engineered systems for industrial processes. Enclosed spaces typically follow the dictates of "function," the result of engineered parameters, with negligible regard, if any, for aesthetic or other classic design considerations.

24 Walker, Permissible Dose, p. 6-12.

25 Walker, Permissible Dose, p. 11-12.

26 Walker, Permissible Dose, p. 11.

27 Glasstone, Principles of Nuclear Reactor Engineering, p. 547-549. See also, U.S. Department of Commerce, National Bureau of Standards, Permissible Dose from External Sources of Ionizing Radiation, Recommendations of the U.S. National Committee on Radiation Protection, Handbook 59 (Washington, D.C.: Superintendent of Documents, 1954), p. 30-32.

28 These were the International Commission on Radiological Protection and United States Advisory Committee on X-Ray and Radium Protection. See Walker, p. 5-11.

29 Handbook 59, p. 61. The complex guidelines identified permissible doses to specific organs and extremities; they varied by the age of the adult as well.

30 Memorandum from C.E. Larson to A.H. Holland, Jr., June 16, 1950, re "Brief History of the ANP Project at ORNL," p. 2-6. Copy found at www.ufx.org/nepa/nepahist1.htm; ORNL central files no. 50-6-74; Human Studies Project no. A-00507.

31 General Electric, Idaho Test Station, Idaho Falls, Idaho, pamphlet, 1959, copy at Idaho State Historical Library, Dworshak Papers, Box 112, File: AEC Idaho Plant.

32 Pratt and Whitney Aircraft Division of United Aircraft Corporation undertook the indirect cycle. It was never built, in part because of unsolved corrosion problems. 
33 Marceau, Thomas E., et al. Hanford Site Historic District, History of the Plutonium Production Facilities, 1943-1990, DOE/RL-97-1047 (Richland, Washington: Battelle Press, Hanford Cultural and Historic Resources Program, US Department of Energy, $2003)$, p. 2-1.24.

34 Loren C. Schmid, Critical Assemblies and Reactor Research (New York: John Wiley and Sons, 1971), p. xiii. GE discussed the Low Power Test facility in APEX-5, p. 65.

35 While the TAN Hangar was under construction, the AEC determined that no nuclear airplanes would be flight-tested over the continental United States. However, ground testing and ground training of maintenance crews would still be necessary, so the hanger was intended to serve as a training facility. See stacy, HAER-ID-33-A, p. 29.

36 Contemporary names for these areas are: Technical support Facility (A\&M and Admin), Contained Test Facility/Specific Manufacturing Facility (FET), Water Reactor Research Test Facility (LPT). The IET continued as IET.

37 The Evendale laboratory was the property of the U.S. Air Force, contracted to GE for propulsion/reactor research. See John F. Hogerton, The Atomic Energy Desk Book (New York: Reinhold Publishing Corporation, 1963), p. 15.

38 Aircraft Nuclear Propulsion Project Engineering Progress Report No. 2, October 1, 1951 - December 31, 1951, DC-51-12-25 (Loveland: Aircraft Gas Turbine Department, GE Company, 1951), p. 68 .

39 ANP Engineering Progress Report No. 2, DC-51-12-25, p. 16, 136-137. Parsons also did a site survey for Muroc Air Force Base (now Edwards A.F.B. in California), also considered for the ANP project.

40 Ralph M. Parsons Company, ANP Facilities (Los Angeles: Ralph M. Parsons Company, no date, but circa 1958), p. 5.

41 Layton McCartney, Friends in High Places, The Bechtel Story, The Most Secret Corporation and How it Engineered the World (New York: Simon and Schuster, 1988), p. 53-54.

42 Web sites found on March 4, 2004, at www.rmpf.org/ rparsons.html and Www.parsons.com. Also, Ralph M. Parsons Company, Airport Facilities: Qualifications, Experience (Los Angeles: Ralph M. Parsons Company, no date), "History of Company," no page. McCartney, Friends in High Places, says Parsons "was effectively dumped" from Bechtel-McCone-Parsons due 
to personality clashes with John McCone.

43 The Ralph M. Parsons Company, Airport Facilities:

Qualifications, Experience (Los Angeles: Ralph M. Parsons Company, no date), p. 175.

44 Biographical sketches in Ralph M. Parsons Company, ANP Facilities (Los Angeles: Ralph M. Parsons Company, no date, but circa 1958), p. 61-69.

45 Thornton, G., and A.J. Rothstein. Comprehensive Technical Report, GE Direct-Air-Cycle ANP Program, Program Summary and References, APEX-901 (Cincinnati: General Electric, 1962), p. 162-163, chart "GE-ANPD Expenditures and Personnel."

46 Atomic Products Division, General Electric Company. Engineering Progress Reports No. 18 and 19, December 1955 and March 1956, APEX-18 and -19 respectively (Cincinnati: General Electric, 1955 and 1956), p. 54 in APEX-18 and p. 7 in APEX-19.

47 Austin Corbin, Jr., Nuclear Aspects of the Remote Site Facilities, APEX-105 (GE ANPP, 1952), p. 6.

48 Corbin, Nuclear Aspects of the Remote Site, p. 6.

49 Richard Meservey, interview with author, october 12, 1998. Also quoted in Stacy, Proving the Principle, p. 123. Droplets of leaked mercury were found for years afterward along the track between $A \& M$ and the IET.

50 Corbin, Nuclear Aspects of the Remote Site, p. 6.

51 Thornton and Rothstein, Program Summary and References, APEX-901, p. 41-44.

52 Thornton and Rothstein, Program Summary and References, APEX-901, p. 50 .

53 ANPP, Nuclear Power Plant Testing in the IET, APEX-131 (Evendale, Ohio: ANPP, May 1953), p. 5, 7.

54 C.C. Gamertsfelder, The Remote Site Particle Problem, APEX-124 (Evendale, Ohio: ANPP, no date, but circa 1953), p. 3.

55 Gamertsfelder, The Remote Site Particle Problem, p. 13.

56 J.F. Kaminsky, Remedial Investigation Final Report with Addenda, EGG-ER-10643 (Idaho Falls: EGG, 1994), p. 2-3; McGarry notes, Picture 2, Photo U-2169-2; Corbin, Nuclear Aspects of the Remote Site, p. 15. 
57 McGarry notes, Photo U-2169-2.

58 Corbin, Nuclear Aspects of the Remote Site, p. 60.

59 N.P. Spofford, Discussion of Criteria for IET Exhaust Gas System, XDC-53-12-74 (Cincinnati: GE ANPP, 1953), p. 4.

60 McGarry notes, Photo 11, U-2700-8. Unburdened by the reactor assembly, the locomotive had a speed capacity of $4.5 \mathrm{mph}$. McGarry's report conflicts with GE's (pre-operational) estimate that its unburdened speed was $15 \mathrm{mph}$. See APEX-131, p. 11.

61 APEX-16, p. 149.

62 APEX-15, p. 177. See HAER Photo 55-2414.

63 McGarry notes, Photo No. 4.

64 Corbin, Nuclear Aspects of the Remote Site, p. 34.

65 Corbin, Nuclear Aspects of the Remote Site, p. 32. The radioisotope of aluminum is $A l-28$, with a half-life of 2.5 minutes. The radioisotopes of iron, a component of steel, Fe-55 and Fe-59, have half-lives of 2.9 years and 46 days, respectively.

66 Dosimeters were supported on wires suspended from the steel frame above the HTRE rig. During one test, pairs were hung above the rig at two-foot intervals, some oriented horizontally, others vertically. See Fred Devens, Data Report D102 A2 Power Plant Testing, IET 13, DC-59-4-710 (Idaho Test Station: Test Engineering, 1959), p. 35 .

67 McGarry notes. See HAER Photo No. ID-33-E-38 for photo of periscope station inside control building.

68 McGarry notes, Photo 4.

69 Any neutrons coming directly down the tunnel from a line of sight to the reactor would be stopped by such a maze, while neutrons that bounced along the walls of the tunnel would be prevented from streaming into the control room.

70 Corbin, Nuclear Aspects of the Remote Site, p. 21-23.

71 The steel and barytes concrete ceiling was estimated to transmit $3 \mathrm{mR}$ per hour in gamma radiation ten minutes after a reactor running 100 hours at $200,000 \mathrm{kw}$ had shut down. See APEX-7, p. 96.

72 Glasstone, Principles of Nuclear Reactor Engineering, p. 
587.

73 See Appendix $F$ for a summary of shielding characteristics of ordinary and heavy concrete.

74 APEX-5, p. 54-56.

75 APEX-7, p. 95.

76 APEX-131, p. 13.

77 APEX-131, p. 9.

78 APEX-13, p. 66.

79 The stack never was raised any higher. See Spofford, Criteria for IET Exhaust Gas System.

80 APEX-131, p. 10-11; Gamertsfelder, The Remote Site Particle Problem, p. 15; Spofford, Criteria for IET Exhaust Gas System, p. $7-8$.

81 Re Weather Tower, see APEX-17, p. 149.

82 APEX-18, p. 44.

83 Apex-131, p. 10

84 APEX-131, p. 9.

85 APEX-131, p. 9.

86 The Design Criteria for the Low Power Test (LPT) Facility suggested that the LPT guard house be "essentially the same" as the IET guard house in that it have "toilet, lighting, heating facilities and Health Physics radiation equipment storage." See APEX-227, p. 35. Thus, these utilities had later become features of the IET guard house.

87 McGarry notes, IET.

88 McGarry notes, Picture 4.

89 APEX-17, p. 150.

90 APEX-18, p. 54.

91 John Tierney, "Take the A-Plane: The Nuclear Bird that Never Flew," Science 823 (Jan-Feb, No. 1), p. 50. 
92 APEX-19, p. 7.

93 William R. Corliss, SNAP Nuclear Reactors (Washington, D.C.: US AEC, 1966), p. 3-5.

94 "Brief History of the SNAPTRAN Program," no date or publication information. Found at INEEL Records Storage Warehouse, Box 157081, file "SNAP."

95 The experiments may also have used one of the cells at the Low Power Test facility, elsewhere at TAN.

96 Richard Meservey, interview with Susan Stacy, October 12, 1998. A fuller story is in Stacy, Proving the Principle, p. 164.

97 Corliss, SNAP Nuclear Reactors, p. 35-38; Stacy, Proving the Principle, p. 268.

98 Corliss, SNAP Nuclear Reactors, p. 7.

99 APEX-131, p. 15

100 McGarry notes, photos 8 and 9.

101 McGarry notes, photos 8 and 9.

102 McGarry notes, photos 8 and 9.

103 McGarry notes, Photos 8 and 9.

104 McGarry notes, photos 8 and 9.

105 Source: Parsons Structural drawing INEEL INDEX No. 106771.

106 APEX-131, p. 15.

107 McGarry notes, photos 8 and 9.

108 APEX-131, p. 15.

109 McGarry notes, photos 8 and 9.

110 APEX-131, p. 17.

111 Source: Parsons architectural drawing A 108, INEEL INDEX Code No. 106760.

112 APEX-131, p. 17.

113 Drawing, INEEL INDEX No. 106767, shows details of Special 
Service Cubicle, circa 1994.

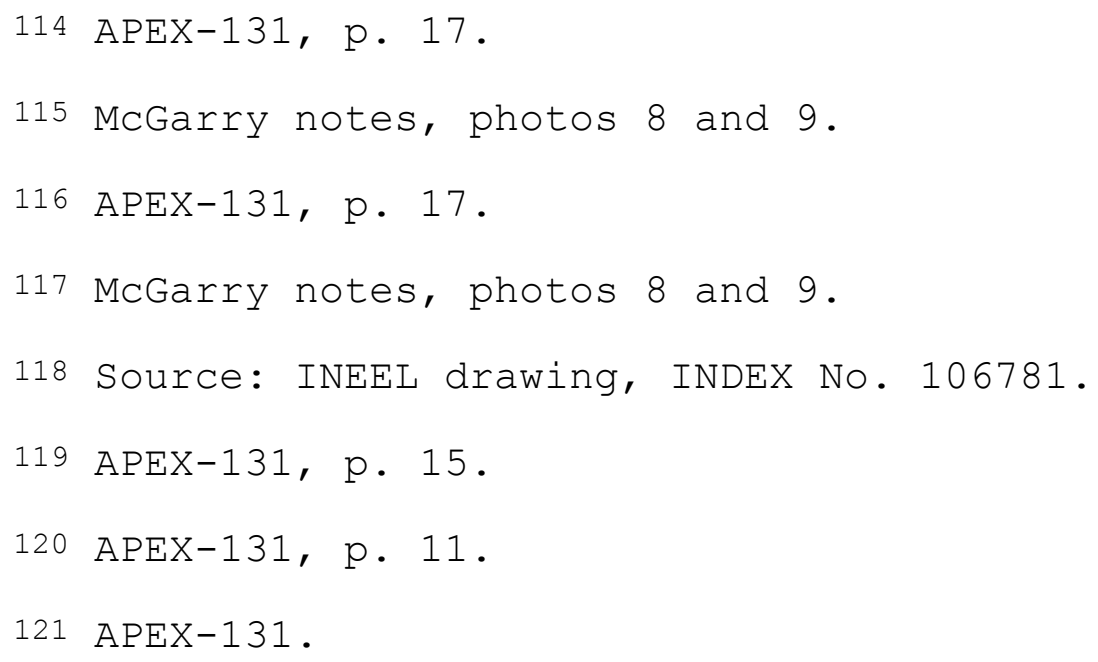

122 McGarry notes, section B, Photo 63-3999 (insert/ withdraw); and APEX-13, p. 54. Another source, Decontamination and Dismantlement of the TAN-615 Assembly and Maintenance Building, HAD-164. Idaho Falls: INEEL, 2001, section 1.1), reports that GE initially intended to assemble fuel rods in the building.

123 Decontamination and Dismantlement of the TAN-615 Assembly and Maintenance Building, HAD-164 (Idaho Falls: INEEL, 2001), section 1.1 .

124 H.A. Heidkamp, Decontamination and Dismantlement Plan for the TAN-615 Assembly and Maintenance Building, INEEL/EXT-2001-01467, Revision 1 (Idaho Falls: Bechtel BWXT Idaho, LLC, May 2002), p. 3-1.

125 Decontamination and Dismantlement of the TAN-615 Assembly and Maintenance Building, HAD-164 (Idaho Falls: INEEL, 2001), section 1.1. Characterization prior to demolition found few hazardous materials exceeding their regulatory limit. Some radionuclides were found, but metals, volatile organic chemicals (and asbestos) constituted the chief concerns. See Heidkamp, p. $3-2$.

126 The construction drawings of 1952 do not show a gable roof over the penthouse. This was a later modification.

127 Amadeo Ramos, A Proposed Hazard Classification for the PM2A Tank Remedial Action at the Idaho National Engineering and Environmental Laboratories, ICP/CON-04-00162 (Idaho Falls, 2004), p. 2 .

128 "Decision Documentation Package Cover Sheet," September 
27, 2000, for Waste Area Group 1, TAN-616. The name PM-2A came from the source of one of the new 1970s evaporator system vessels. evaporator system in the 1970s. It was acquired from a U.S. Army reactor of that designation which had been decommissioned in Camp Century, Greenland. See Ramos, A Proposed Hazard Classification, p. 2 .

129 TAN is Waste Area Group No. 1 (WAG-1) as identified in Federal Facility Agreement and Consent Order in the Matter of the U.S. Department of Energy Idaho National Engineering Laboratory ("INEL"), signed in 1991 by DOE Idaho Operations Office, the State of Idaho, and the U.S. Environmental Protection Agency, Administrative Docket No. 1088-06-29-120.

130 "Decision Documentation Package Cover Sheet," September 27, 2000, for Waste Area Group 1, TAN-616.

131 Kevin Streeper, personal communication with author, May 10,2004 .

132 See also Ralph M. Parsons drawing 1480-4-ANP/GE-3-201, INEEL INDEX No. 034-9999-65-693-107438.

133 Source: Ralph M. Parsons 1480-7-ANP/GE 3- 648-A-H\&V-1, date November 1958, INEEL Index Code No. 034-0648-00-693-107454.

134 Leo Barbour, personal communication with author, March 24 , 2004 .

135 D.J. Haley and T.G. Hedahl, Safety Analysis for the Process Experimental Pilot Plant, PG-WM-84-019 (Idaho Falls: $E G \& G, 1984), p .5,16$.

136 J.E. Langford, Design Review Plan for the Process Experimental Pilot Plant (PREPP), EGG-TF-6057 (Idaho Falls: EG\&G, $1982), \mathrm{p} .1$.

137 L.G. Gale, PREPP Deactivation Plan, WM-PD-90-015 (Idaho Falls: EG\&G, 1990), p. 1-3, 62 .

138 Idaho Operations Office, Comprehensive Facility and Land Use Plan, DOE/ID-10514 (Idaho Falls: DOE, 1996), p. A-26.

139 Source: Ralph M. Parsons 1229-24-ANP/GE-3-603-A-1, INEEL Index Code No. 033-0609-00-693-107394.

140 APEX-18, p. 198; Technical Basis Document, found at wWw.cdc.gov/niosh/ocas/pdfs/tbd/ineel2.pdf on April 20, 2004, Procedure No. ORAUT-TKBS-0007-2, effective date 11/07/2003, Rev. 00 , page 22. "Temperature coefficient" is a measure of a reactor's behavior when the fuel heats up. It is positive if 
increasing temperatures promote continuing fission; negative, if it reduces the fission rate.

141 APEX-227, p. 8

142 McGarry notes, photos 15 and 16.

143 See G.R. Williams, Design Criteria for the Low Power Test Facility, APEX-227 (ANPP Idaho: GE, April 1956). Re Arrington, see Thumbnail Sketch, 1957, p. 11.

144 APEX-227, p. 4.

$145 \mathrm{APEX}-227, \mathrm{p} .5,17$.

146 J.A. Hoefer, Summary Hazards Report For Critical

Experiments with the HOTCE Reactor, APEX-345 (Evendale: GE Atomic Products Division, no date), p. 9.

147 See Design Criteria, APEX-227, p. 11. The as-built drawings for the LPT indicate several other departures from the original design criteria.

148 APEX-345, p. 13. The accident analysis estimated that the maximum dosage likely to be received by someone outside the test cell during a maximum accident was 3 rem. See p. 41.

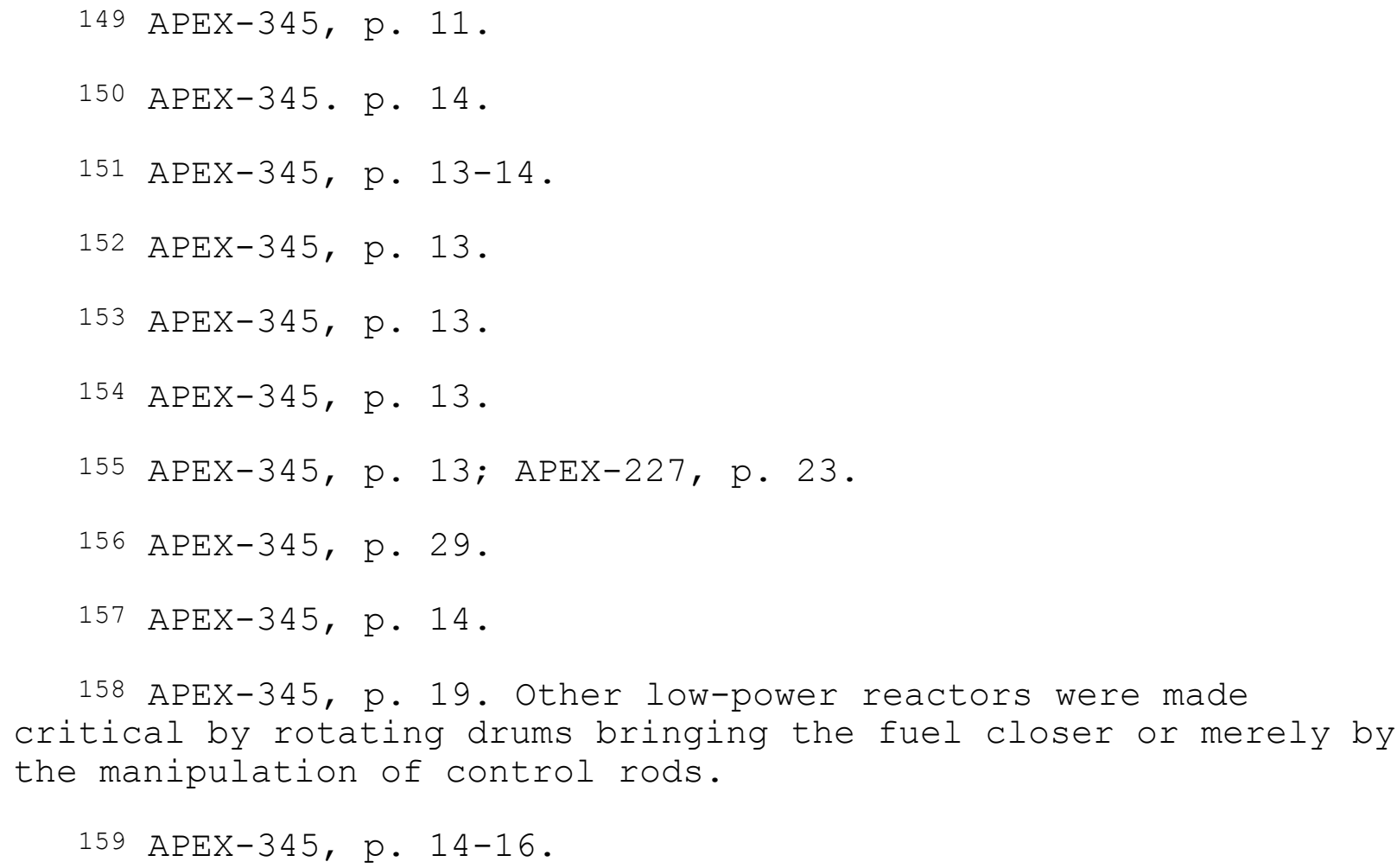


160 APEX-345, p. 14-18.

161 APEX-901, p. 25.

162 Thumbnail Sketch, 1958, p. 12.

163 L. Jones, Design Criteria Shield Test Facility, APEX-217 (Idaho Falls: GE/ANPP, 1956), p. 5, 9-10. See also APEX-20, p. $132-133$.

164 History of Oak Ridge Laboratory. Found in May 2004 at WWW. ornl.gov.

165 APEX-217, p. 11.

166 C.W. Luke and D.L. Gilliland, Hazards Summary Report for Susie Reactor, APEX-459 (Cincinnati: GE/ANP, February 3, 1959), p. 5 .

167 APEX-459, p. 35.

168 A note on INEEL Drawing No. 037-0645/0646-61-693-107382

(Ralph M. Parsons 1229-17 ANP/GE-6-645-S-7) indicates that there was to be a one-inch separation between the two buildings.

169 APEX-459, p. 9.

170 APEX-459, p. 9.

171 APEX-459, p. 9-10.

172 APEX-459, p. 11.

173 Cobalt-60 was a typical gamma source.

174 See INEEL Drawing 037-0645-40-693-107370, also numbered as Ralph M. Parsons, 1229-17-ANP?GE-6-645-MS-2.

175 APEX-459, p. 12.

176 For an account of the SL-1 accident, see Stacy, Proving the Principle, chapters 15 and 16.

177 Jay Kunze, personal communication with author, February 5, 1999 .

178 W.P. Walsh, Test Program and Procedures for STF Program A, Initial Organic Reactor Material Irradiation on Susie Reactor North Face, DC-61-7-706 (Idaho Falls: GE Nuclear Materials and Propulsion Operation, 1961), p. 9. 
179 Hogerton, Desk Book, p. 295, 298. Another component of the Maritime Program was the N.S. Savannah, a government-owned demonstration ship that begin its sea trials in 1962. Savannah was powered by a conventional pressurized water reactor.

180 630A Maritime Nuclear Steam Generator Progress Report No. 7, GEMP-274 (Cincinnati: GE Nuclear Materials and Propulsion Operation, March 1964), p. 17.

181 GEMP-274, p. 77-78.

182 GEMP-274, p.99-100. GE also studied the feasibility of using Army Reactors Area facilities elsewhere at the NRTS.

183 Thumbnail Sketch, January 1965, p. 32. Pressurized-water reactors were the propulsive power in the U.S. Navy's surface ships.

184 U.S. AEC, Idaho Operations Office press release, "EBOR facility construction authorized to start at AEC's National Reactor Testing Station in Idaho," June 14, 1963, INEEL Records Storage Warehouse, Idaho Falls, Box 148473, file "EBOR." Hereafter cited as INEEL Records Warehouse.

185 Thumbnail Sketch, January 1965, p. 32.

186 "Let's Visit EBOR," page 2, unauthored paper found in INEEL Records Warehouse, BOx 148473, file "EBOR."

187 Selig Hecht, Explaining the Atom (New York: Viking Press, $1947)$, p. 147 .

188 Idaho Operations Office press release, "EBOR facility construction authorized..," June 14, 1963.

189 Thumbnail Sketch, July 1971, p. 36-37.

190 Idaho Operations Office press release, "EBOR facility construction authorized...," June 14, 1963.

191 "Nuclear Kettle Shipped to Idaho," Oakland Tribune, November 5, 1964, clipping with no page no. in INEEL Records Warehouse, Box 148473, file "EBOR."

192 Memorandum "from Dale Cook," March 11, 1966, INEEL Records Warehouse, Box 148473, file "EBOR."

193 "EBOR report for July 14, 1966," INEEL Records Storage Warehouse, Box 157081, file "EBOR."

194 To EBOR file from V.A. Walker, October 9, 1962, ACRS 
meeting on EBOR; to E.K. Loop from W.J. Tupper, November 1, 1965; INEEL Records Warehouse, Box 157081, file "EBOR."

195 To F.E. Smith from V.V. Hendrix, March 31, 1965, INEEL Records Warehouse, Box 157081, file "EBOR."

196 To W.L. Ginkel from E.K. Loop, May 31, 1966; to Milton Shaw from W.L. Ginkel, June 28, 1966; INEEL Records Warehouse, Box 157081, file "EBOR."

197 Stacy, Proving the Principle, p. 176-177.

198 Jack M. Holl, Roger M. Anders, Alice L. Buck, United States Civilian Nuclear Power Policy, 1954-1984: A Summary History DOE/MA-0152 (Washington, D.C.: U.S. Department of Energy History Division, 1986), p. 13-14.

199 U.S. AEC Idaho Operations Office press release, "AEC terminating Experimental Beryllium Oxide Reactor Project at NRTS in Idaho," December 20, 1966, INEEL Records Warehouse, Box 148473, file "EBOR."

200 To W.L. Ginkel from E.K. Loop, May 31, 1966, INEEL Records Warehouse, Box 157081, file "EBOR."

201 Thumbnail Sketch, 1971, p, 37; Comprehensive Facility and Land Use Plan, March 1996, DOE/ID-10514, p. 211-212.

202 Stacy, TAN Hangar-629, HAER ID-33-A, p. 31-43.

203 McGarry notes, photo no. 7.

204 D.J. Blevins et al, Flight Engine Test Facility Design Criteria, APEX-225 (Idaho Falls: General Electric, 1955), p. 11.

205 APEX-911, p. 49-50.

206 APEX-225, p. 5.

207 See Stacy, HAER Report ID-33-A on Hangar Building TAN-629 for details and descriptions of the shadow shield.

208 APEX-225, p. 15-21.

209 APEX-225, p. 15-21.

210 APEX-37, p. 147.

211 APEX-225, p. 26-27. Foam suppressant was described in Preliminary Scoping Track 2 Summary Report for Operable Unit 1-08 , INEL-94.0170 (Idaho Falls: INEL, 1995), p. 4-1. The "urban 
legend" is that this material was made partly of oxblood.

212 This building was similar to the Chlorinator building at the LPT area.

213 Source: Ralph M. Parsons 1229-2 ANP/GE 5-639-A, S, H\&V-1, INEEL Index No. 036-0632/0639-00-693-107149. For similar building drawing, see HAER Photo No. ID-33-E-218.

214 Stacy, Proving the Principle, p. 178.

215 See Stacy, Proving the Principle, chapters 14, 18, and 19 from which this introduction of LOFT has been taken.

216 L.F. Burdge, LOFT Integral Test System, Final Safety Analysis Report, Revision 1, volume 2 of 3, LOFT-FSAR-V2-R 1 (Idaho Falls: EG\&G Idaho, Inc., August 1977), p. 8-29 to 8-32.

217 J.M. Waage, Preliminary Safety Analysis Report, LOFT Facility, IDO-16981 (Idaho Falls: Phillips Petroleum Co., April 1964), p. IV-2.

218 Stacy, Proving the Principle, p. 230, identifies related STEP test programs.

219 J. Fell and S.M. Modro, An Account of the OECD LOFT Project, OECD LOFT-T-3907 (Idaho Falls: OECD LOFT, May 1990), p. $\mathrm{A}-4$ to $\mathrm{A}-6$.

220 Theoretical Consequences of Major Accidents in Large Nuclear Power Plants, WASH-740, March 1957. For an account of this report, see Robert P. Crease, Making Physics, A Biography of Brookhaven National Laboratory, 1946-1972 (Chicago: University of Chicago Press, 1999), p. 275-277.

221 This description simplifies the actual geography of the LOFT building. It was not situated squarely on the cardinal points of the compass. A line drawn between the center of the railroad door and the "north wing" would lie east of a true north axis.

222 John Commander, interview by Susan Stacy, July 14, 1998.

223 Burdge, LOFT SAR, p. 8-4 to 8-5.

224 Burdge, LOFT SAR, p. 8-11 to 8-13.

225 Burdge, LOFT SAR, p. 8-18 to 8-20.

226 Stacy, Proving the Principle, p. 179 
227 Joint Committee on Atomic Energy, Hearings on AEC

Authorizing Legislation, Fiscal Year 1968 (Washington: Government Printing Office, 1967), p. 761.

228 Stacy, Proving the Principle, p. 182.

229 Re N.S. Savannah: Jason Bohne, "He does what's needed to get the job done" (Lockheed Martin Idaho Technologies Company) STAR (August 18, 1998), p. 3.

230 John Commander, July 14, 1998. See also Stacy, Proving the Principle, p. 223-224.

231 Samuel McCracken, The War Against the Atom (New York: Basic Books, 1982), p. 21 .

232 Stacy, Proving the Principle, p. 224. In the aftermath of the accident, a number of INEL facilities were employed to help deal with the TMI-2 reactor. Tests at the Power Burst Facility predicted how much fuel had melted and collapsed into the bottom of the TMI-2 reactor vessel. The crafts engineers designed a "core bore" machine at TAN-607 to allow the first camera access into the damaged core.

233 D. Hicks and K. Sato, "Contributions of the OECD/LOFT Project to Nuclear Safety," Proceedings of an Open Forum sponsored by the OECD Nuclear Energy Agency with the support of the OECD/LOFT Spanish Consortium, May 9-11, 1990 (Madrid, Spain: OECD Nuclear Energy Agency, 1990), p. 44-45.

234 Hicks and Sato, p. 49.

235 Hicks and Sato, p. 46.

236 Hicks and Sato, p. 53. 
IDAHO NATIONAL ENGINEERING AND ENVIRONMENTAL LABORATORY, TEST AREA NORTH SCOVILLE VICINITY

BUTTE COUNTY

IDAHO
HAER NO. ID-33-E

INEEL/EXT-04-02536

PHOTOGRAPHS

WRITTEN HISTORICAL AND DESCRIPTIVE DATA

TEST AREA NORTH

Historical American Engineering Record 
National Park Service

Western Region

Department of the Interior

Seattle, Washington 98104

\section{HISTORIC AMERICAN ENGINEERING RECORD}

INDEX TO PHOTOGRAPHS

IDAHO NATIONAL ENGINEERING AND ENVIRONMENTAL HAER NO. ID-33-E LABORATORY, TEST AREA NORTH

Scoville Vicinity

Butte county

Idaho

Many drawings documented below display the stamp, "Official Use Only." INEEL's Classification Office requested, in light of the fact that Internet views of the drawings are shown together with their captions, that each such caption indicate that the drawing was approved for public release. Other stamps, such as "classified" or "secret" were removed from original Aircraft Nuclear Propulsion (ANP) drawings many years ago (date not known). These removals appear as blackout or burn marks on the drawing images.

The following large-format photos, historical photos, and photos of architectural drawings are arranged in five groups, each group representing one of five complexes at Test Area North (TAN). The first set of large-format photos, historic photos, and drawings are of the Initial Engine Test Area (IET). In order, the next groups are the Assembly and Test Area (A\&M), the Administration Area (ADM), the Low Power Test Area (LPT), and the Flight Engine Test (FET)/Loss of Fluid Test (LOFT) Area.

For additional narrative and photographic documentation for the Aircraft Nuclear Propulsion Project, the Flight Engine Test Area, and its Hangar (Building TAN-629), please refer to HAER Report ID-33-A. See also the narrative for this report on Test Area 
North, HAER Report ID-33-E.

All of the drawings photographed for this index were made from aperture cards (a microfilm medium) because INEEL destroyed the original drawings several years ago. Thus, the "negative" images are black-on-white. The prints are white-on-black. A reader may find it more convenient to examine drawings by looking at the negatives instead of the prints.

\section{INITIAL ENGINE TEST COMPLEX}

HAER photographs ID-33-E-1 through ID-33-E-30 were taken of the IET facility prior to or during demolition. Interior views were taken January 22, 1998, by Mike Crane; exterior, on April 13, 1998 by Ron Paarmann.

Note: Large-format photographs of TAN-624, which served as the Mobile Test Building in the ANP program and as the Containment Entry in the LOFT program, will be found with LOFT photographs.

ID-33-E-1 IET DISTANT CONTEXTUAL VIEW OF COUPLING STATION, RETAINING WALL, AND SHIELDED CONTROL BUILDING (TAN-620). CAMERA FACING NORTHEASTERLY. INEEL NEGATIVE NO. HD-21-7-4.

ID-33-E-2 IET DISTANT CONTEXTUAL VIEW OF SHIELDED CONTROL BUILDING (TAN-620). CAMERA FACING SOUTHWESTERLY. INEEL NEGATIVE NO. HD-21-8-3.

ID-33-E-3 IET DISTANT CONTEXTUAL VIEW OF EARTH COVERING OVER SHIELDED ROADWAY. CAMERAL FACING SOUTH. INEEL NEGATIVE NO. HD-21-9-1.

ID-33-E-4 IET CONTEXTUAL VIEW OF COUPLING STATION, TRACKS, AND RETAINING WALL. EXPERIMENT SHACK ON LEFT SIDE OF COUPLING STATION REMAINS FROM SNAPTRAN TESTS. CAMERA FACING NORTHERLY. INEEL NEGATIVE NO. HD-21-7-3.

ID-33-E-5 IET CONTEXTUAL VIEW OF ENTRANCE TO SHIELDED ROADWAY. CAMERAL FACING WEST. STACK AND OTHER BUILDINGS HAVE BEEN REMOVED. INEEL NEGATIVE NO. HD-21-7-2.

ID-33-E-6 IET CONTEXTUAL VIEW OF TAN-620, SHIELDED CONTROL BUILDING. CAMERA FACING NORTHWESTERLY. NON-IET-RELATED MONITORING DEVICE IN FOREGROUND. INEEL NEGATIVE NO. $\mathrm{HD}-21-8-2$.

ID-33-E-7 IET CONTROL BUILDING (TAN-620). AIR INTAKE STRUCTURE. CAMERA FACING NORTH. PART OF WING WALL HAS BEEN 
DAMAGED. INEEL NEGATIVE NO. HD-21-7-1.

ID-33-E-8 IET FUEL TRANSFER PUMP BUILDING (TAN-625). CAMERA

FACING SOUTH. INEEL NEGATIVE NO. HD-21-8-1.

ID-33-E-9 IET CONTEXTUAL VIEW. CAMERA FACING SOUTHERLY. REAR OF COUPLING STATION AT RIGHT OF VIEW. CONTROL BUILDING (TAN-620) TO ITS LEFT. EXHAUST STACK AND DUCT HAVE BEEN REMOVED. INEEL NEGATIVE NO. HD-21-9-2.

ID-33-E-10 IET PERSONNEL TUNNEL. ELECTRICAL AND OTHER CONDUIT RUNS ALONG CEILING. INEEL NEGATIVE NO. HD-21-3-3.

ID-33-E-11 IET ENTRANCE TO CONTROL BUILDING (TAN-620) FROM SHIELDED ROADWAY. CAMERA FACING WEST. NOTE CORRUGATED STEEL WALL, CURBS ALONG ROADWAY, DRAINAGE GRATE. ROOM BEYOND IS TURNAROUND AREA. INEEL NEGATIVE NO. HD-21-6-1.

ID-33-E-12 IET CONTROL BUILDING (TAN-620) TURNAROUND AREA. CAMERA PROBABLY FACING NORTHERLY. VENTILATION DUCTS NEAR CEILING. SIGN SAYS, "PARKING POSITION NO. 3, USE THIS SPACE LAST." POURED CONCRETE WALLS. INEEL NEGATIVE NO. HD-21-5-4.

ID-33-E-13 IET CONTROL BUILDING (TAN-620). INTERIOR SERVICE ROOM. PIPING. INEEL NEGATIVE NO. HD-21-1-3.

ID-33-E-14 IET CONTROL BUILDING (TAN-620). INTERIOR SERVICE ROOM, DETAIL OF PIPING. INEEL NEGATIVE NO. $\mathrm{HD}-21-2-1$.

ID-33-E-15 IET CONTROL BUILDING (TAN-620). INTERIOR PERSONNEL SERVICE ROOM. SIGN NEXT TO SHOWER STALL SAYS, "FIGHT ATHLETE'S [FOOT] WITH SANI-MIST." INEEL NEGATIVE NO. HD-21-1-1.

ID-33-E-16 IET CONTROL BUILDING (TAN-620). INTERIOR ROOM. CONCRETE WALLS, FLOOR, CEILING. INEEL NEGATIVE NO. $\mathrm{HD}-21-1-4$.

ID-33-E-17 IET CONTROL BUILDING (TAN-620). INTERIOR ROOM. SIGN SAYS, "EMERGENCY EQUIPMENT FOR METAL FIRES." INEEL NEGATIVE NO. HD-21-1-2.

ID-33-E-18 IET CONTROL BUILDING (TAN-620). INTERIOR SERVICE ROOM. GENERAL ELECTRIC CONTROL PANEL AND RELATED PIPING. INEEL NEGATIVE NO. HD-21-2-3.

ID-33-E-19 IET CONTROL BUILDING (TAN-620). INTERIOR SERVICE 


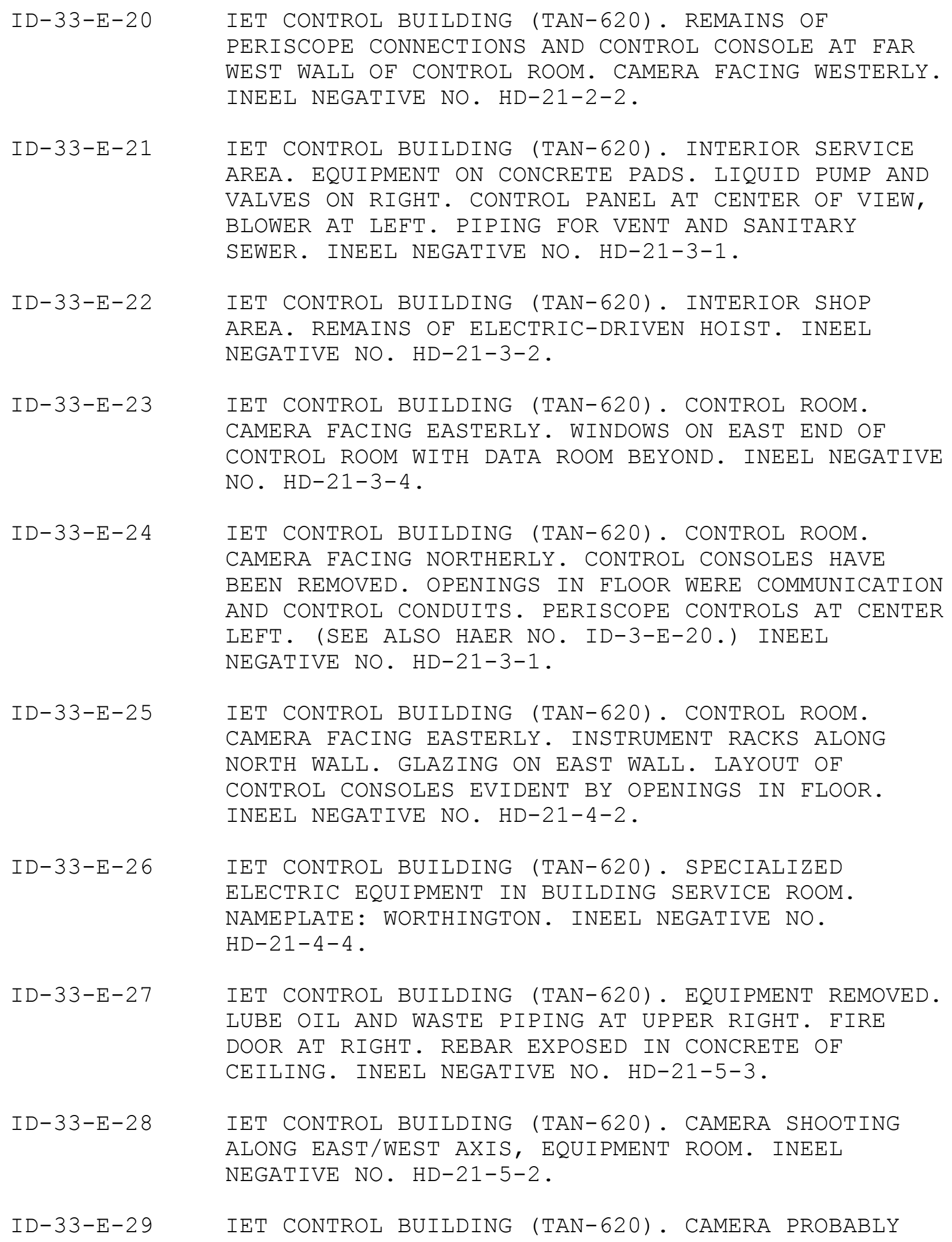


ID-33-E-30

FACING WEST IN EQUIPMENT ROOM. NAME BRAND: $\mathrm{P} \& H$ HEAVI-LIFT. NOTE DOORWAY AND CORRIDOR AT LEFT OF VIEW. INEEL NEGATIVE NO. HD-21-5-3.

IET CONTROL BUILDING (TAN-620). SWITCH PANELS. INEEL NEGATIVE NO. HD-21-5-1.

Photos ID-33-E-31 through ID-33-E-56 are historical photographs of the IET from the INEEL photo collection. When known, date, photographer, and camera position are noted.

ID-33-E-31 IET. AERIAL VIEW OF PROJECT, 95 PERCENT COMPLETE. CAMERA FACES EAST. LEFT TO RIGHT: STACK, DUCT, MOBILE TEST CELL BUILDING (TAN-624), FOUR-RAIL TRACK, DOLLY. RETAINING WALL BETWEEN MOBILE TEST BUILDING AND SHIELDED CONTROL BUILDING (TAN-620) JUST BEYOND. NORTH OF CONTROL BUILDING ARE TANK BUILDING (TAN-627) AND FUEL-TRANSFER PUMP BUILDING (TAN-625). GUARD HOUSE AT UPPER RIGHT ALONG EXCLUSION FENCE. CONSTRUCTION VEHICLES AND TEMPORARY WAREHOUSE IN VIEW NEAR GUARD HOUSE. DATE: JUNE 6, 1955. INEEL NEGATIVE NO. 55-1462.

ID-33-E-32 IET. COUPLING STATION AND TRACK FOUNDATIONS UNDER CONSTRUCTION. CAMERA FACING NORTHERLY. FOUR-RAIL TRACK FOUNDATIONS LEAD TO COUPLING STATION. SERVICE LEADS FROM HTRE WILL GO THROUGH OPENING FOR "QUICK CONNECTS" BELOW. RETAINING WALL UNDER CONSTRUCTION WILL SEPARATE EARTHEN SHIELDING OF CONTROL BUILDING (OUT OF VIEW TO RIGHT) FROM COUPLING STATION AND TRACK. DATE: OCTOBER 20, 1954. INEEL NEGATIVE NO. 12550.

ID-33-E-33 IET. FOUR-RAIL TRACK AND RAILROAD CREW. CAMERA FACING NORTHERLY. COUPLING STATION AT END OF TRACK. SHIELDING ABOVE CONTROL BUILDING (TAN-620) AT RIGHT OF VIEW. AIR INTAKE STRUCTURE PROJECTS FROM CONTROL BUILDING. DATE: NOVEMBER 19, 1954. INEEL NEGATIVE NO. 12997.

ID-33-E-34 IET. PERSONNEL ACCESS CORRIDOR UNDER CONSTRUCTION. DATE: JULY 19, 1954. INEEL NEGATIVE NO. 11334.

ID-33-E-35 IET. CONSTRUCTION VIEW OF CONTROL BUILDING (TAN-620). CAMERA FACES EAST, TOWARDS WEST WALL OF CONTROL BUILDING. STRUCTURE AT LEFT SHOWS PROGRESS FORMING THE PERSONNEL TUNNEL THAT WILL CONNECT CONTROL BUILDING TO COUPLING STATION. NOTE TWO ROUND OPENINGS FOR PERISCOPES NEAR LADDER AT 
RIGHT. DATE: AUGUST 20, 1954. INEEL NEGATIVE NO. 11709 .

ID-33-E-36 IET. DIESEL ENGINE FOR EMERGENCY GENERATOR IS HEADED FOR INSTALLATION IN SHIELDED CONTROL BUILDING (TAN-620). DATE: SEPTEMBER 21, 1954 . INEEL NEGATIVE NO. 12145.

ID-33-E-37 IET. COUPLING STATION. MAN HOLDS FLEXIBLE COUPLERS TO REACTOR DOLLY AND HTRE RIG. DATE: APRIL 22, 1955. INEEL NEGATIVE NO. 55-1010.

ID-33-E-38

IET. PERISCOPES. MEN ARE IN CONTROL ROOM OF CONTROL BUILDING (TAN-620). CAMERA FACING WEST. NOTE CONDUIT HOLES IN FLOOR AT LOWER LEFT. DATE: MAY 20, 1955. INEEL NEGATIVE NO. 55-1299.

ID-33-E-39 IET. CONTROL ROOM IN CONTROL BUILDING (TAN-620). TERMINAL PANELS FOR INSTRUMENTATION WIRING. NOTE ALARM HORN AND EMERGENCY LIGHT AT RIGHT EDGE OF VIEW. CABLE REEL COMES FROM COLLIER, PAWTUCKET, R.I. DATE: FEBRUARY 1955. INEEL NEGATIVE NO. $55-362$.

ID-33-E-40 IET. JET FUEL TANK BEING LOWERED INTO POSITION BELOW GRADE. TWO TANKS ALREADY IN PLACE. DATE: OCTOBER 18, 1954. INEEL NEGATIVE NO. 12535.

ID-33-E-41 IET. AERIAL VIEW DURING CONSTRUCTION, CAMERA FACING SOUTHWEST. CONTROL BUILDING (TAN-620) IN CENTER. RETAINING WALL IN PLACE ON WEST SIDE. TANK BUILDING (TAN-627) AND FUEL-TRANSFER PUMP BUILDING (TAN-625) NORTH OF CONTROL BUILDING. SHIELDED ROADWAY NOT YET BUILT. FOUNDATION OF STACK AT RIGHT EDGE OF VIEW. DATE: NOVEMBER 24, 1954. INEEL NEGATIVE NO. 13198.

ID-33-E-42 IET. EXHAUST STACK FOUNDATION UNDER CONSTRUCTION. REINFORCED CONCRETE FOOTINGS FOR DUCT AT RIGHT OF STACK. FOUNDATION IS IN OCTAGONAL SHAPE. DATE: OCTOBER 29, 1954. INEEL NEGATIVE NO. 12711.

ID-33-E-43 IET. STACK INTERIOR. MASONS LAY FIRE BRICK LINER, LEAVING AIR LAYER BETWEEN BRICKS AND CONCRETE WALL. DATE: MAY 20, 1955. INEEL NEGATIVE NO. $55-1306$.

ID-33-E-44 IET. EXCLUSION GUARD HOUSE, 71.8 PERCENT COMPLETE. CAMERA FACES NORTHERLY. PUMICE BLOCK WALLS, CANOPY OVER CONCRETE SLABS. DATE: OCTOBER 20, 1954. INEEL 
NEGATIVE NO. 12541.

ID-33-E-45 IET. WEATHER INSTRUMENTATION TOWER, LOCATED SOUTH OF CONTROL BUILDING. CAMERA FACES WEST. DATE: AUGUST 17, 1955. INEEL NEGATIVE NO. 55-2414.

ID-33-E-46 IET. MOBILE TEST CELL BUILDING (TAN-624). CAMERA FACES SOUTHERLY. NOTE FOLDING DOOR PANELS, TRAVEL RAILS ON EACH SIDE. PART OF STRUCTURAL ALUMINUM FRAMEWORK IS VISIBLE INSIDE. DATE: APRIL 22, 1955. INEEL NEGATIVE NO. 55-1012.

ID $-33-E-47$

IET. COUPLING STATION UNDER PREPARATION FOR FIRST TEST. CAMERA FACING NORTH. BANK OF LIGHTS AND PERISCOPE SHIELDS AT EACH SIDE OF COUPLING STATION. NOTE VIEW OF STACK AND TWIN (DIVIDED) DUCT CONNECTIONS THROUGH TRANSOM OPENING OF COUPLING STATION. DRAINS TRANSVERSE TO TRACKS. RETAINING WALL AT RIGHT OF VIEW. DATE: JUNE 22, 1955. INEEL NEGATIVE NO. 55-1698.

ID $-33-E-48$

IET. AERIAL VIEW OF SNAPTRAN DESTRUCTIVE EXPERIMENT IN 1964. CAMERA FACING NORTHERLY. TEST CELL BUILDING (TAN-624) IS POSITIONED AWAY FROM COUPLING STATION. WEATHER TOWER IN RIGHT FOREGROUND. DIVIDED DUCT JUST BEYOND COUPLING STATION. AIR INTAKE STRUCTURE ON SOUTH SIDE OF SHIELDED CONTROL ROOM. EXPERIMENT IS ON DOLLY AT COUPLING STATION. DATE: 1964. INEEL NEGATIVE NO. $64-1736$.

ID-33-E-49 SNAPTRAN-2 EXPERIMENT MOUNTED ON DOLLY BEING HAULED BY SHIELDED LOCOMOTIVE FROM IET TOWARD A\&M TURNTABLE. NOTE LEADS FROM EXPERIMENT GATHERED AT COUPLING BAR IN LOWER RIGHT OF VIEW. ANOTHER DOLLY IN VIEW AT LEFT. CAMERA FACING SOUTHEAST. PHOTOGRAPHER: PAGE COMISKEY. DATE: AUGUST 25, 1965. INEEL NEGATIVE NO. 65-4503.

ID-33-E-50 IET. SNAPTRAN-2 EXPERIMENT. PROJECT PHOTOGRAPHER WORKING ON "STATION C" CAMERA. PHOTOGRAPHER: PAGE COMISKEY. DATE: SEPTEMBER 22, 1965. INEEL NEGATIVE NO. 65-4949.

ID-33-E-51 IET. SNAPTRAN PHOTOGRAPHER ADJUSTING MIRRORS AT CAMERA STATION FOR RECORDING SNAPTRAN TEST. PHOTOGRAPHER: PAGE COMISKEY. DATE: SEPTEMBER 22, 1965.

ID-33-E-52 IET. SNAPTRAN. FLYING A KITE IN THE SERVICE OF 


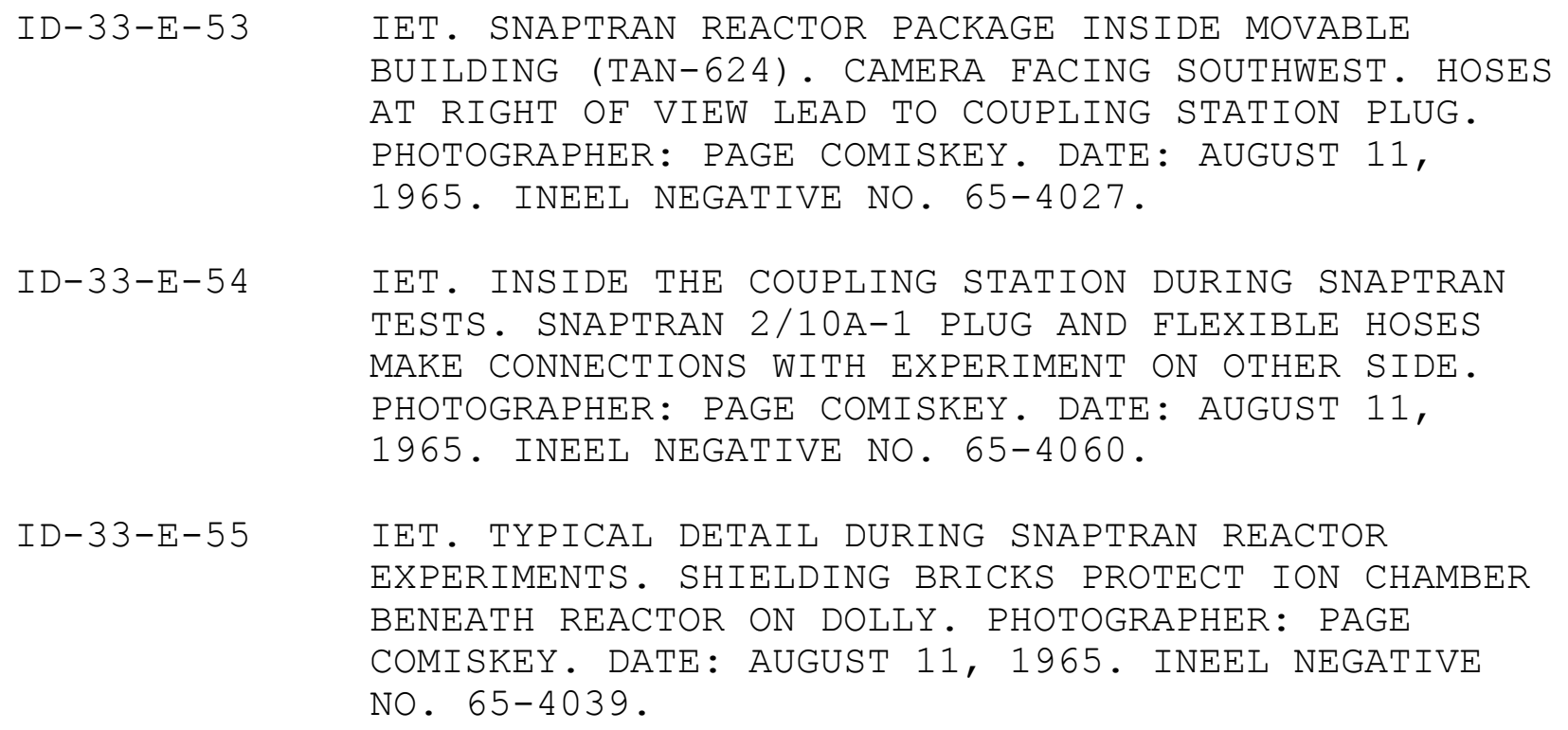

Photos ID-33-E-56 through ID-33-E-70 are of architectural drawings of IET buildings constructed at TAN during the Aircraft Nuclear Propulsion program.

ID-33-E-56 IET AREA PLOT AND UTILITIES PLAN. INCLUDES DRAINAGE. RALPH M. PARSONS 902-4-ANP-U-310. DATE: FEBRUARY 1954. APPROVED BY INEEL CLASSIFICATION OFFICE FOR PUBLIC RELEASE. INEEL CODE NO. 035-0100-00-693-106898.

ID-33-E-57 IET. MOVABLE TEST CELL BUILDING (TAN 624). PLANS, SECTIONS, AND ELEVATIONS SHOW TRAPEZOIDAL SHAPE OF FRONT/REAR ELEVATIONS, VERTICAL SLIDING DOOR PANELS, WHEELS, PERISCOPE AND CAMERA LOCATIONS, FIXED CONCRETE WALL, AND RELATIONSHIP TO COUPLING STATION (TAN-620) AND RAIL TRACK. RALPH M. PARSONS 902-4-ANP-624-A 329. DATE: FEBRUARY 1954. APPROVED BY INEEL CLASSIFICATION OFFICE FOR PUBLIC RELEASE. INEEL INDEX CODE NO. 035-0624-00-693-106911.

ID-33-E-58 IET. COUPLING STATION (TAN-620), PLANS AND SECTIONS. CONCRETE SHIELDING WALLS AND BORON SURFACE TREATMENT. ELEVATION SHOWS TWO FLOOR LEVELS, POSITION OF PERISCOPES, AND STAIRWAYS. RALPH M. PARSONS 902-4-ANP-620-A 325. DATE: 


$$
\begin{aligned}
& \text { ID-33-E-59 IET. PERISCOPE SHIELDING AND INSTALLATION DETAILS. } \\
& \text { SHOWS RANGE OF SCANNING HEAD, REMOVABLE CONCRETE } \\
& \text { CAP, CONCRETE SHIELDING. RALPH M. PARSONS } \\
& \text { 902-4-ANP-620-A 324. DATE: FEBRUARY 1954. APPROVED } \\
& \text { BY INEEL CLASSIFICATION OFFICE FOR PUBLIC RELEASE. } \\
& \text { INEEL INDEX CODE NO. 035-0620-00-693-106909. } \\
& I D-33-E-60 \\
& I D-33-E-61 \\
& I D-33-E-62 \\
& \text { IET EXHAUST GAS STACK. SECTION, WEST ELEVATION, }
\end{aligned}
$$

ID-33-E-63 IET. CONTROL AND EQUIPMENT BUILDING (TAN-620) FLOOR PLAN. SCHEDULE OF FURNITURE AND EQUIPMENT. RALPH M. PARSONS 902-4-ANP-A 320. DATE: FEBRUARY 1954. APPROVED BY INEEL CLASSIFICATION OFFICE FOR PUBLIC RELEASE. INEEL INDEX CODE NO. 035-0620-00-693-106905.

ID-33-E-64 IET. CONTROL AND EQUIPMENT BUILDING (TAN-620) SECTIONS. DEPTH AND PROFILE OF EARTHEN SHIELD, TUNNELS. RALPH M. PARSONS 902-4-ANP-620-A-321. DATE: FEBRUARY 1954. INEEL INDEX CODE NO. 035-0620-00-693-106906.

ID-33-E-65 IET. CONTROL AND EQUIPMENT BUILDING (TAN-620). DETAILS AND ROOM FINISH SCHEDULE. RALPH M. PARSONS 902-4-ANP-620-A 322. APPROVED BY INEEL 


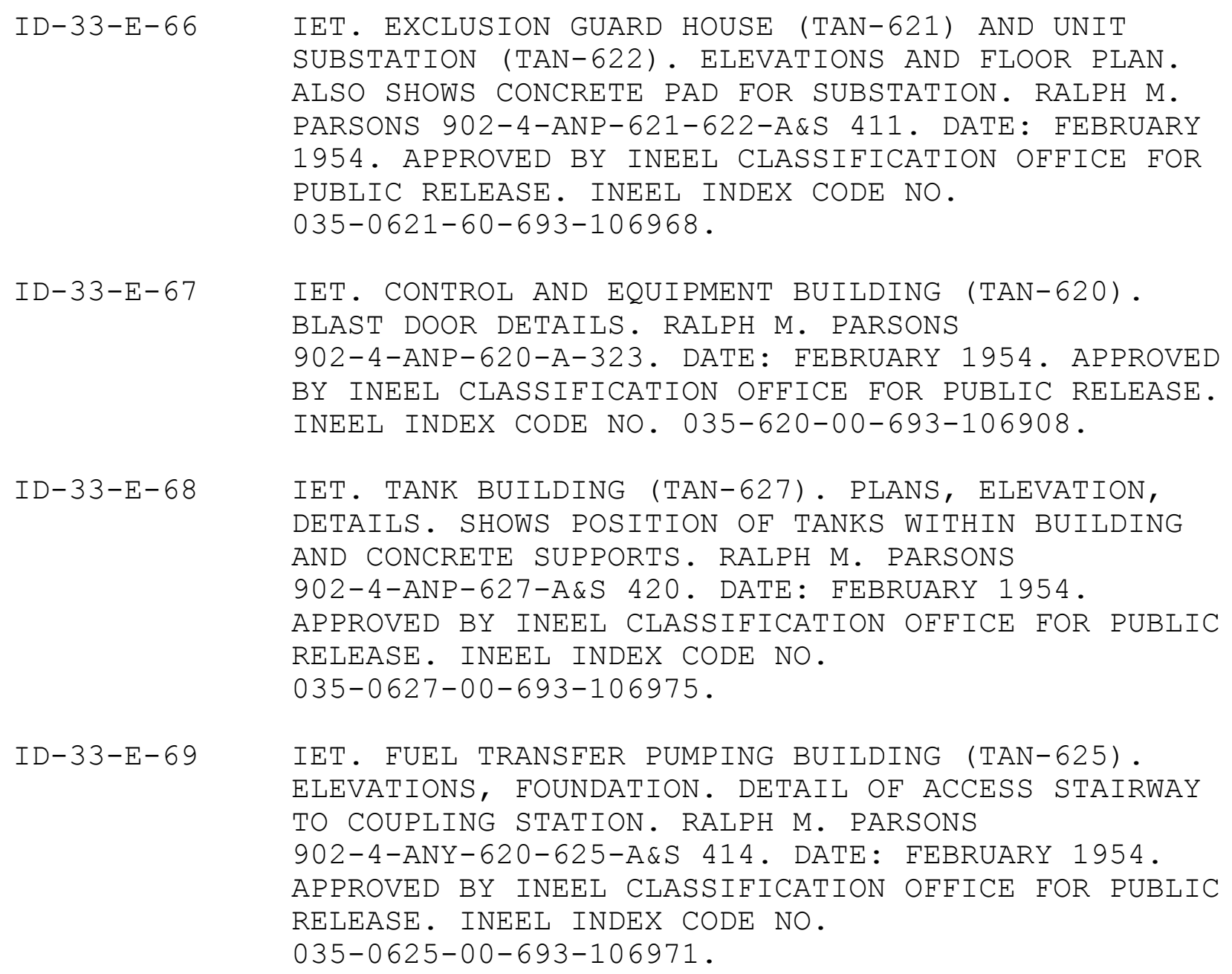

\section{ASSEMBLY AND MAINTENANCE COMPLEX}

Photos ID-33-E-70 through ID-33-E-110 were taken of buildings at the ANP Assembly and Maintenance area prior to demolition. HAER-quality large-format photos have not been taken of the Assembly and Maintenance Building (TAN-607), the Hot Shop, as it has not been scheduled for demolition as of the date of this report. However, historic photographs and architectural drawings are documented in this report. Photographer is Mike Crane, unless otherwise indicated.

ID-33-E-70 A\&M. HOT CELL ANNEX (TAN-633) CONTEXTUAL VIEW ALSO SHOWING EAST FACADE. CAMERA FACING WEST. NOTE CORRIDOR CONNECTING ANNEX TO POOL AREA OF TAN-607. PUMICE BLOCK WALLS. DATE: MARCH 2004. INEEL NEGATIVE NO. HD-39-2-2. 
ID-33-E-71 A\&M. HOT CELL ANNEX (TAN-633) NORTH FACADE. GABLED CANOPY SHELTERS NORTH END OF MONORAIL. HIGH BAY OF HOT SHOP BEYOND. DATE: MARCH 2004. INEEL NEGATIVE NO. HD-39-2-4.

ID-33-E-72 A\&M. HOT CELL ANNEX (TAN-633) WEST FACADE. CAMERA FACING EAST. DEMOLITION EQUIPMENT IN FOREGROUND. MONORAIL AT LEFT OF VIEW. DATE: MARCH 2004. INEEL NEGATIVE NO. HD-39-2-1.

ID-33-E-73 A\&M. HOT CELL ANNEX (TAN-633) INTERIOR OF OPERATING GALLERY. CAMERA PROBABLY FACING SOUTH. AT EACH SIDE OF VIEWING WINDOWS ARE "MASTER" MANIPULATORS WHICH CONTROL "SLAVES" WITHIN HOT CELL. DATE: MARCH 2004. INEEL NEGATIVE NO. $\mathrm{HD}-39-2-3$.

ID-33-E-74 A\&M. SHIELDED LOCOMOTIVE (TAN-807), PARKED AND INACTIVE ON TRACK WEST OF A\&M BUILDING. CAMERA FACING NORTHEAST. DATE: MARCH 2004. INEEL NEGATIVE NO. HD-39-10-1.

ID-33-E-75 A\&M. SHIELDED LOCOMOTIVE (TAN-807). CAMERA FACING WEST. DATE: MARCH 2004. INEEL NEGATIVE NO. HD-39-10-2.

ID-33-E-76 A\&M. SHIELDED LOCOMOTIVE (TAN-607). CAMERA FACING SOUTHWEST. DATE: MARCH 2004. INEEL NEGATIVE NO. HD-39-10-3.

ID-33-E-77 A\&M. CONTEXTUAL VIEW OF TURNTABLE CONTROL SHACK (TAN-661, BUILT IN 1970) AND RADIOACTIVE PARTS SECURITY STORAGE AREA. CAMERA FACING NORTHWESTERLY AND SHOOTING ACROSS TURNTABLE. DOOR TO SHACK IS TO RIGHT. JANUARY 29, 2003. INEEL NEGATIVE NO. HD-33-2-1.

ID-33-E-78 A\&M. TURNTABLE CONTROL SHACK (TAN-661). OBLIQUE VIEW, CAMERA FACING EASTERLY. DOOR. DATE: JANUARY 29, 2003. INEEL NEGATIVE NO. HD-33-2-4.

ID-33-E-79 A\&M. TURNTABLE CONTROL SHACK (TAN-661) INTERIOR DETAIL. TAKEN FROM DOOR INTO SWITCH PANEL. DATE: JANUARY 29, 2003. INEEL NEGATIVE NO. HD-33-3-2.

ID-33-E-80 A\&M. OUTDOOR TURNTABLE. CAMERA FACING EAST TOWARD HOT SHOP (TAN-607). VIEW TAKEN JUST BEFORE DEMOLITION BEGAN. CRANE IN VIEW. DATE: FEBRUARY 3, 2003. INEEL NEGATIVE NO. HD-37-5-1. 
$I D-33-E-81$

$I D-33-E-82$

$\mathrm{ID}-33-\mathrm{E}-83$

$I D-33-E-84$

$I D-33-E-85$

$I D-33-E-86$

$I D-33-E-87$

$I D-33-E-88$

$I D-33-E-89$

$\mathrm{ID}-33-\mathrm{E}-90$
A\&M. OUTDOOR TURNTABLE. WORKINGS AND DESIGN EXPOSED DURING DEMOLITION. TURNTABLE PLATFORM TRAVELED ON CONCENTRIC CIRCULAR RAILS, THIS ONE THE INNER RAIL. RADIOACTIVE PARTS STORAGE AREA IN BACKGROUND. DATE: FEBRUARY 3, 2003. INEEL NEGATIVE NO. HD-37-2-2.

A\&M. OUTDOOR TURNTABLE. WORKINGS AND DESIGN EXPOSED DURING DEMOLITION. DETAIL OF PLATFORM WHEELS AND STRUCTURAL STEEL BEAMS RESTING UPON WHEEL. WOOD DECK ABOVE STEEL BEAMS. DATE: FEBRUARY 3, 2003. INEEL NEGATIVE NO. HD-37-4-1.

A\&M. OUTDOOR TURNTABLE. WORKINGS AND DESIGN EXPOSED DURING DEMOLITION. DETAIL OF RADIALLY PLACED STEEL BEAMS SUPPORTING ROTATING PLATFORM. PART OF SHIELDED LOCOMOTIVE AT UPPER RIGHT. DATE: FEBRUARY 3, 2003. INEEL NEGATIVE NO. HD-37-1-3.

A\&M. OUTDOOR TURNTABLE. WORKINGS AND DESIGN EXPOSED DURING DEMOLITION. OUTER EDGE OF TURNTABLE SHAPED BY CONCRETE. OUTER WHEEL AND RAIL. DATE: FEBRUARY 3, 2003. INEEL NEGATIVE NO. HD-37-1-2.

A\&M. OUTDOOR TURNTABLE. WORKINGS AND DESIGN EXPOSED DURING DEMOLITION. VIEW BETWEEN TWO OF THE FOUR RAILS OF THE TRACK. NOTE MOTOR AND ELECTRICAL CONDUIT. DATE: FEBRUARY 3, 2003. INEEL NEGATIVE NO. HD-37-1-1.

A\&M. OUTDOOR TURNTABLE DURING DEMOLITION. CONCRETE FOUNDATION SUPPORTS INNER RAIL OF TURNTABLE. DATE: FEBRUARY 3, 2003. INEEL NEGATIVE NO. HD-37-1-4.

A\&M. OUTDOOR TURNTABLE DURING DEMOLITION. CONCRETE STRUCTURAL SUPPORTS RADIATE FROM CENTER TOWARDS OUTER EDGE OF TURNTABLE. DETAIL OF WHEEL. DATE: FEBRUARY 3, 2003. INEEL NEGATIVE NO. HD-37-3-2.

A\&M. GUARD HOUSE (TAN-638), CONTEXTUAL VIEW. BUILT IN 1968. CAMERA FACES SOUTH. GUARD HOUSE CONTROLLED ACCESS TO RADIOACTIVE WASTE STORAGE TANKS BEYOND AND TO LEET OF VIEW. DATE: FEBRUARY 4, 2003. INEEL NEGATIVE NO. HD-33-4-1.

A\&M. GUARD HOUSE (TAN-638), CONTEXTUAL VIEW WITH CAMERA FACING NORTHEASTERLY TOWARDS TAN-607. DATE: FEBRUARY 4, 2003. INEEL NEGATIVE NO. HD-33-4-2.

A\&M. GUARD HOUSE (TAN-638). OBLIQUE VIEW OF NORTH 


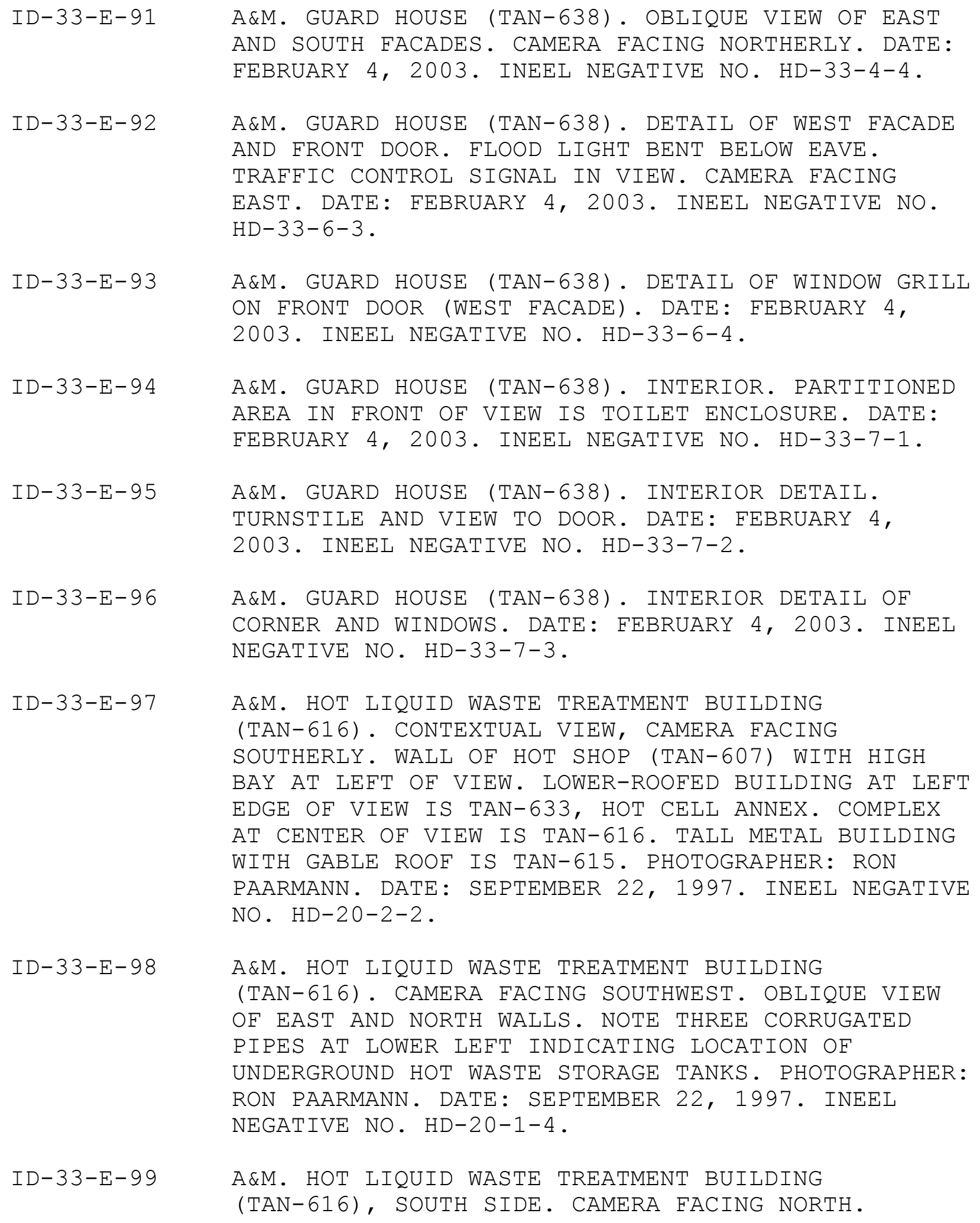




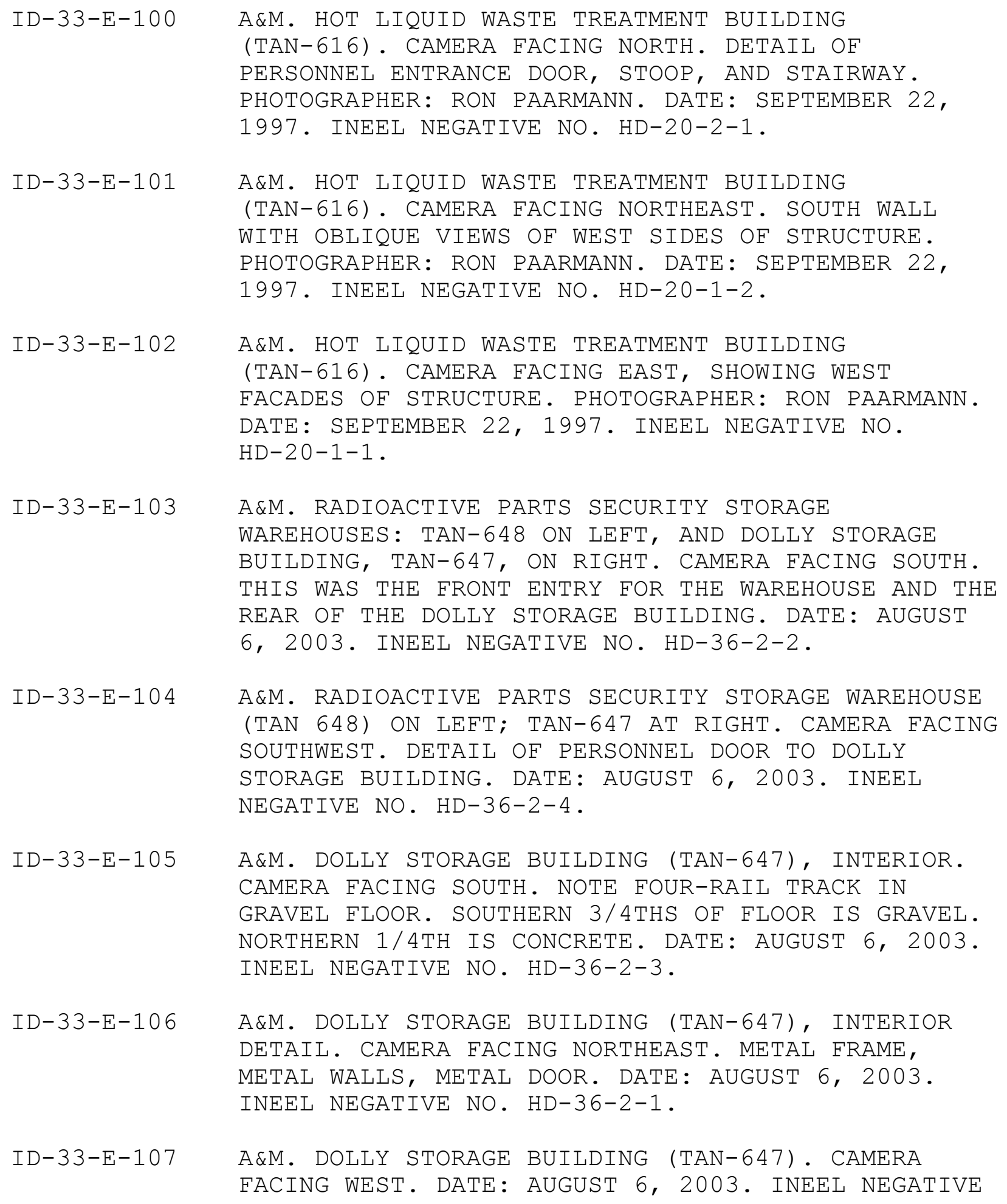


NO. HD-36-1-1.

ID-33-E-108 A\&M. DOLLY STORAGE BUILDING (TAN-647). OBLIQUE VIEW, CAMERA FACING NORTHWEST. DATE: AUGUST 6, 2003. INEEL NEGATIVE NO. HD-36-1-2.

ID-33-E-109 A\&M. DOLLY STORAGE BUILDING (TAN-647). CAMERA FACING SOUTH. PHOTOGRAPHER: MIKE CRANE. DATE: AUGUST 6, 2003. INEEL NEGATIVE NO. HD-36-1-3.

ID-33-E-110 A\&M. DOLLY STORAGE BUILDING (TAN-647). CAMERA FACING NORTH. RAIL TRACKS CURVE INTO BUILDING. TAN-648 ON RIGHT. DATE: AUGUST 6, 2003. INEEL NEGATIVE NO. HD-36-1-4.

Photos ID-33-E-111 through ID-33-E-156 are historical photographs of buildings at the ANP Assembly and Maintenance area. Photographer names and dates are indicated when known.

ID-33-E-111 A\&M. AERIAL VIEW OF TURNTABLE AND A\&M BUILDING (TAN-607). POOL, HOT SHOP, COLD SHOP, AND MACHINE SHOP ARE COMPLETED. TRACK LEADING TO LEFT EDGE OF VIEW GOES TO THE IET. ANCIENT LAKE SHORELINE AND BERM BEYOND A\&M BUILDING. CAMERA FACING EAST. ADMINISTRATION BUILDINGS BEYOND BERM. DATE: NOVEMBER 24, 1954. INEEL NEGATIVE NO. 13205.

ID-33-E-112 A\&M. A\&M BUILDING (TAN-607). CAMERA FACING EAST. FROM LEFT TO RIGHT, POOL SECTION, HOT SHOP, COLD SHOP, AND MACHINE SHOP. BIPARTING DOORS TO HOT SHOP ARE IN OPEN POSITION BEHIND SHROUD. FOUR-RAIL TRACKS LEAD TO HOT SHOP AND COLD SHOP. DATE: AUGUST 20, 1954. INEEL NEGATIVE NO. 11706.

ID-33-E-113 A\&M. SPECIAL SHIELDING MATERIALS. STOCKPILE OF MAGNETITE, USED FOR MAKING HIGH-DENSITY CONCRETE, AND LOADING CONVEYOR NEAR TAN-607 CONSTRUCTION SITE. DATE: SEPTEMBER 25, 1953. INEEL NEGATIVE NO. 8710 .

ID-33-E-114 A\&M. TAN-607. DETAIL OF FUEL STORAGE POOL UNDER CONSTRUCTION. CAMERA IS ON BERM AND FACING NORTHWEST. NOTE DEPTH OF EXCAVATION. FORMWORK UNDERWAY FOR FLOOR AND CONCRETE WALLS OF POOL; WALL BETWEEN POOL AND VESTIBULE. AT CENTER LEFT OF VIEW, FOUNDATION FOR LIQUID WASTE TREATMENT PLANT IS POURED. DATE: AUGUST 25, 1953. INEEL NEGATIVE NO. 8541 .

ID-33-E-115 A\&M. TAN-607. CONSTRUCTION DETAIL SHOWING SOUTH 


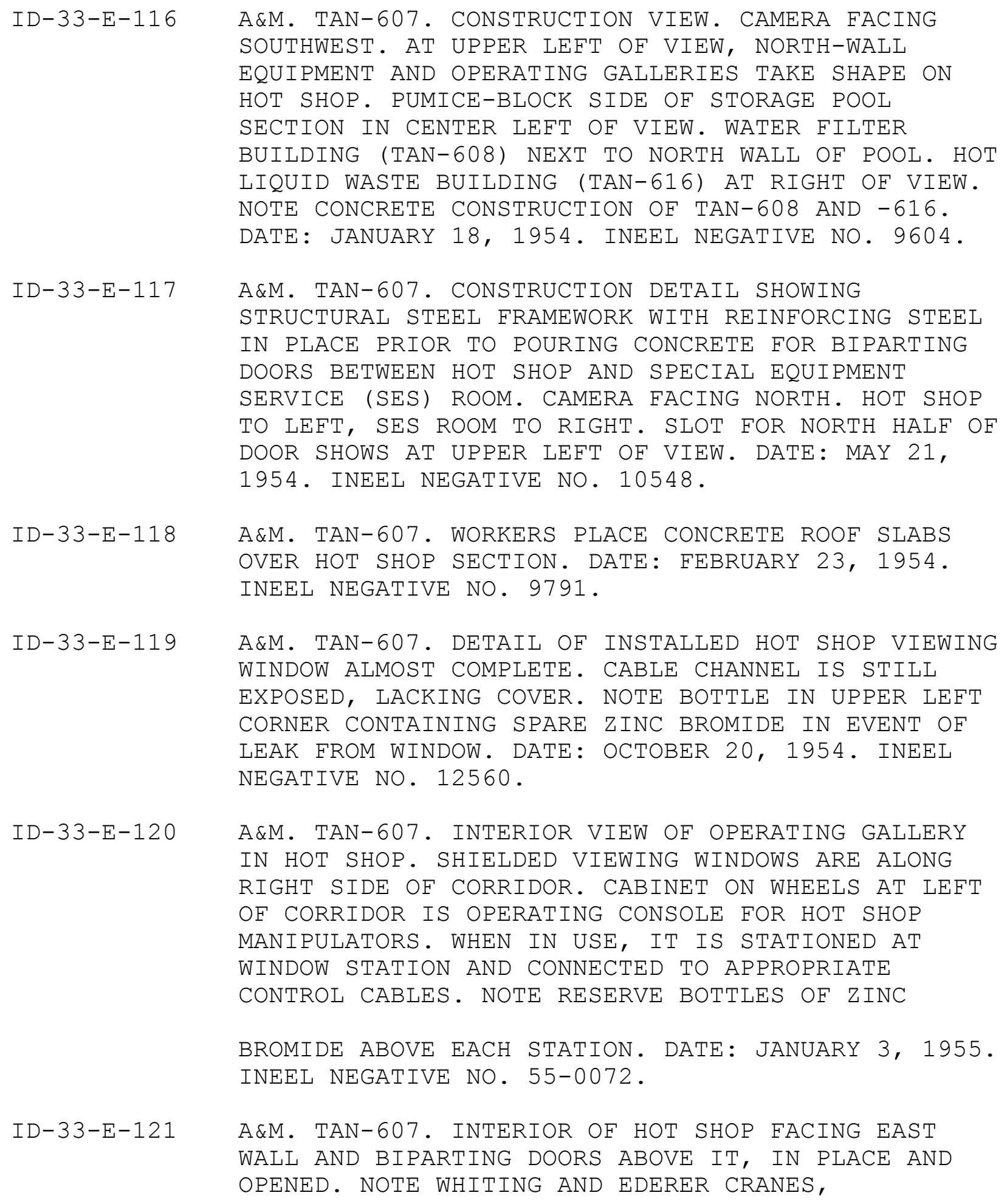




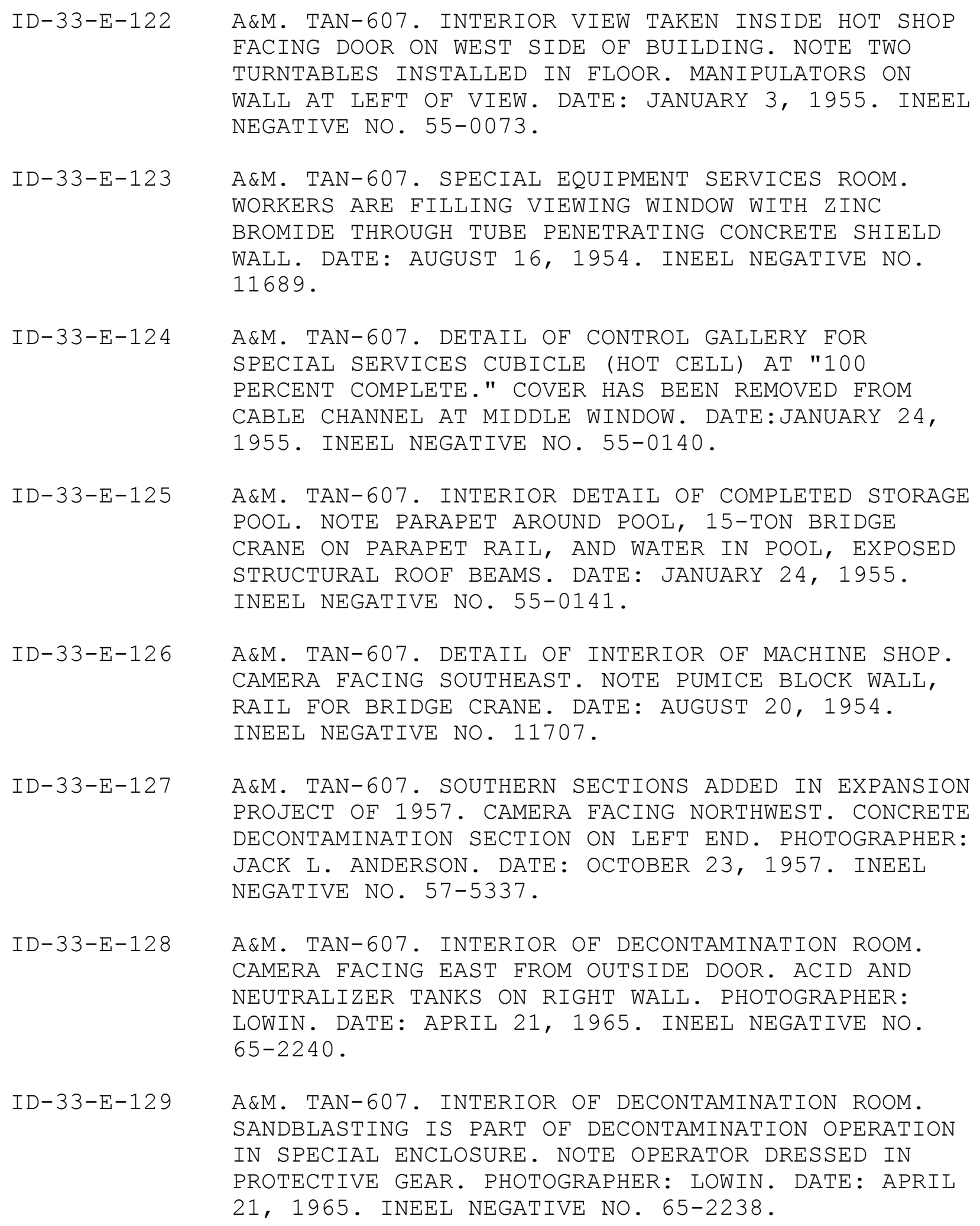

ID-33-E-129 A\&M. TAN-607. INTERIOR OF DECONTAMINATION ROOM. SANDBLASTING IS PART OF DECONTAMINATION OPERATION IN SPECIAL ENCLOSURE. NOTE OPERATOR DRESSED IN PROTECTIVE GEAR. PHOTOGRAPHER: LOWIN. DATE: APRIL 21, 1965. INEEL NEGATIVE NO. 65-2238. 
A\&M. TAN-607. INTERIOR OF DECONTAMINATION ROOM. OVERALL VIEW LOOKING DOWN FROM 30 FEET. CAMERA FACING WEST FROM PERSONNEL LADDER. OPERATION IN PROGRESS WITH HOOK ABOUT TO LIFT CABINET. PHOTOGRAPHER: LOWIN. DATE: APRIL 21, 1965. INEEL NEGATIVE NO . 65-2239,

ID-33-E-131 A\&M. TAN-607 EXPANSION OF 1957. CAMERA FACING SOUTHWEST. COMPONENTS TEST LAB. DOOR TO SPECIAL SOURCE VAULT IN REAR OF ROOM AT RIGHT OF VIEW. PHOTOGRAPHER: JACK L. ANDERSON. DATE: NOVEMBER 21, 1957. INEEL NEGATIVE NO. 57-5883.

ID-33-E-132 A\&M. HOT LIQUID WASTE HOLDING TANKS. CAMERA FACES SOUTHEAST. LOCATED IN VICINITY OF TAN-616, HOT LIQUID WASTE TREATMENT PLANT. DATE: NOVEMBER 13, 1953. INEEL NEGATIVE NO. 9159.

ID-33-E-133 A\&M. JET ENGINE TEST PAD AND CONTROL BUILDING (TAN-609). CAMERA FACING WESTERLY. ENGINE PAD AT LEFT, CONTROL SECTION (PUMICE BLOCK) ON RIGHT. DATE: SEPTEMBER 19, 1955. INEEL NEGATIVE NO. $55-2766$.

ID-33-E-134 A\&M. TAN-609. JET ENGINE TEST PAD AND CONTROL BUILDING. CAMERA FACING SOUTHEAST. DATE: JULY 19, 1954. INEEL NEGATIVE NO. 11344.

ID-33-E-135 A\&M. INTERIOR OF JET ENGINE TEST PAD CONTROL ROOM (TAN-609). DATE: OCTOBER 29, 1954. INEEL NEGATIVE NO. 12701.

ID-33-E-136 A\&M. JET ENGINE TEST BUILDING (TAN-609). EXTERIOR. EQUIPMENT INSIDE ROLL-UP DOOR IS BLOWDOWN TEST FACILITY, PART OF LOFT/SEMISCALE PROGRAM. NOTE WIDTH OF CENTRAL SECTION SERVING AS BLAST PROTECTION FOR OPERATOR ON LEET SIDE. PHOTOGRAPHER: CAHOON. DATE: JULY 22, 1965. INEEL NEGATIVE NO. 65-3703.

ID-33-E-137 A\&M. TAN-609. LOOP APPARATUS INSIDE TEST BUILDING BEING PREPARED FOR TEST. PHOTOGRAPHER: CAHOON. DATE: JULY 22, 1965. INEEL NEGATIVE NO. 65-3700.

ID-33-E-138 A\&M. JET ENGINE TEST PAD (TAN-609) WAS USED IN 1968 FOR SEMISCALE TEST APPARATUS. VIEW OF BLOWDOWN TEST WITH ROLLUP DOOR OPEN. WHEN BREAK IN PRESSURIZED COOLANT LOOP IS SIMULATED, STEAM IS RELEASED SUDDENLY. INEEL NEGATIVE NO. 68-3179. 
A\&M. RADIOACTIVE PARTS SECURITY STORAGE AREA UNDER CONSTRUCTION. CAMERA FACING SOUTHERLY. BUILDING ON LEFT IS TAN-648, WAREHOUSE FOR RADIOACTIVE PARTS . STEEL FRAMEWORK IS VISIBLE. BUILDING ON RIGHT IS TAN-647, DOLLY STORAGE WAREHOUSE. NOTE FIBERGLASS WINDOWS IN SIDE WALL. PHOTOGRAPHER: M. HOLMES. DATE: NOVEMBER 23, 1959. INEEL NEGATIVE NO. 59-6083.

ID-33-E-140

A\&M. RADIOACTIVE PARTS SECURITY STORAGE AREA. CAMERA FACING NORTH. FOUR-RAIL TRACK LEADS TO SOUTH END (FRONT DOOR) OF TAN-647. DOLLY IS LOADED WITH TRANSPORT CASK AND LINER. TO ITS RIGHT, VIEW SHOWS BACK END OF TAN-648, WHICH IS ACCESSED BY ROAD ON ITS NORTH SIDE. PHOTOGRAPHER: M. HOLMES. DATE: DECEMBER 21, 1959. INEEL NEGATIVE NO. 59-6080.

ID-33-E-141 A\&M. RADIOACTIVE PARTS SECURITY STORAGE AREA. CAMERA FACING NORTHWEST. OUTDOOR STORAGE OF CONCRETE STORAGE CASKS. PHOTOGRAPHER: M. HOLMES . DATE: NOVEMBER 21, 1959. INEEL NEGATIVE NO. 59-6081.

ID-33-E-142 A\&M. OUTDOOR TURNTABLE UNDER CONSTRUCTION. WELL FOR OUTER RAIL IS BEING FORMED. MOTOR WORKS ON RIGHT. DATE: AUGUST 25, 1953. INEEL NEGATIVE NO. 8537 .

ID-33-E-143 A\&M. OUTDOOR TURNTABLE. FOUNDATION SUPPORTS BEING FORMED. DATE: SEPTEMBER 25, 1953. INEEL NEGATIVE NO. 8694.

ID-33-E-144 A\&M. OUTDOOR TURNTABLE. FOUNDATIONS COMPLETE. CENTER PIVOT IN PLACE. DATE: NOVEMBER 20, 1953. INEEL NEGATIVE NO. 9184.

ID-33-E-145 A\&M.OUTDOOR TURNTABLE. STEEL RAIL SUPPORTS GO IN PLACE. DATE: JUNE 22, 1954. INEEL NEGATIVE NO. 11017 .

ID-33-E-146 A\&M. OUTDOOR TURNTABLE. AERIAL VIEW OF TRACKAGE AS OF 1954. CAMERA FACES NORTHEAST ALONG LINE OF TRACK HEADING FOR THE IET. UPPER SET OF EAST/WEST TRACKS HEAD FOR THE HOT SHOP; THE OTHER, FOR THE COLD SHOP. DATE: NOVEMBER 24, 1954. INEEL NEGATIVE NO. 13203.

ID-33-E-147 A\&M. HOT CELL ANNEX (TAN-633). CAMERA FACING EAST. CONSTRUCTION VIEW OF NORTH AND WEST WALLS. 


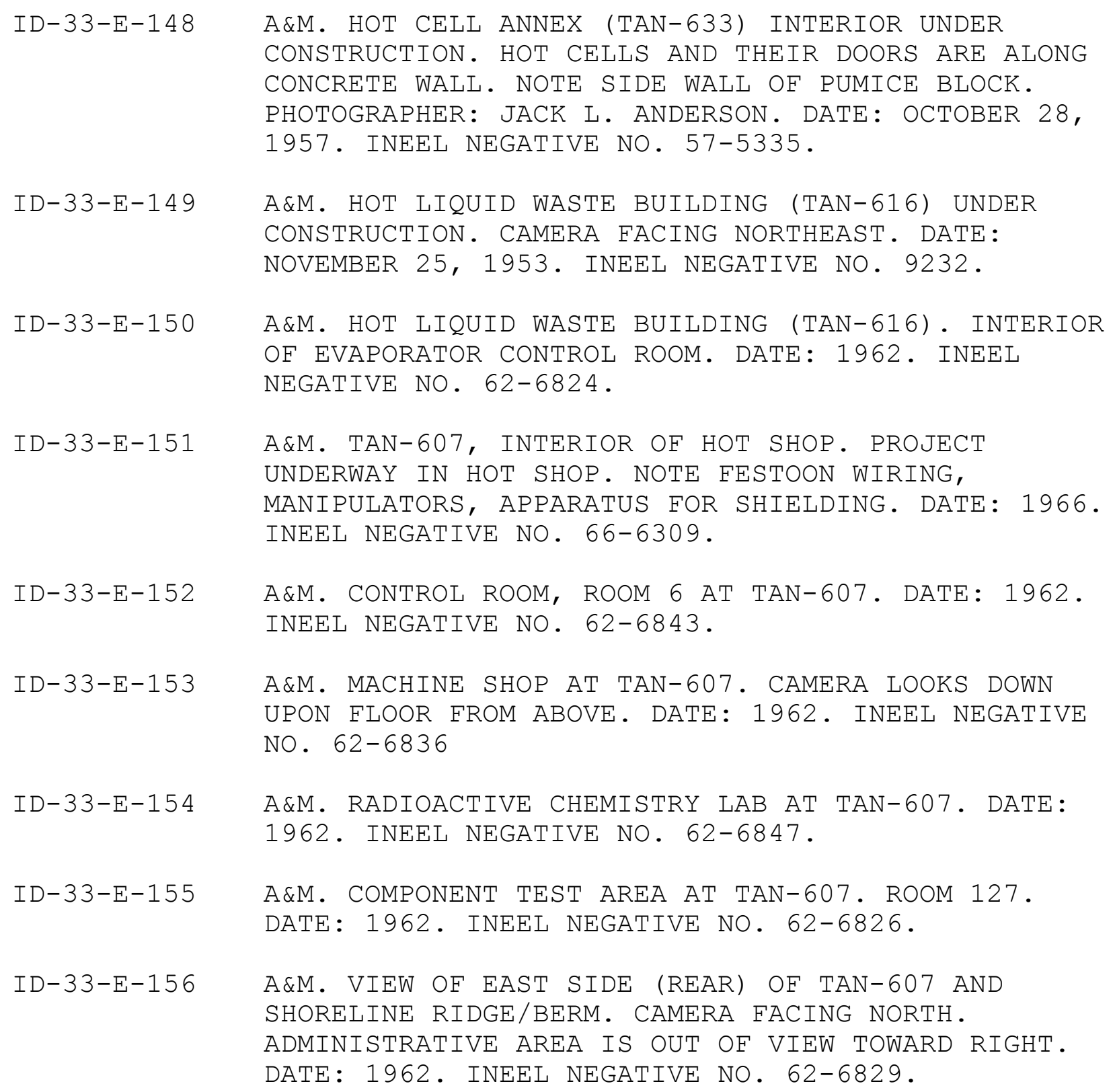

Photographs ID-33-E-157 through ID-33-E-186 are of architectural drawings of the ANP Assembly and Maintenance buildings.

ID-33-E-157 A\&M. GRADING AND DRAINAGE PLAN. SHOWS NATURAL GROUND ELEVATION OF THE (PRESUMED) DRY LAKE-BED SHORE AND THE BERM SHIELDING THE ADMINISTRATIVE AREA FROM THE HOT SHOP AREA. RALPH M. PARSONS 902-2\&3-ANP-U 4. DATE: DECEMBER 1953. APPROVED BY INEEL CLASSIFICATION OFFICE FOR PUBLIC RELEASE. INEEL CODE NO. 032-0000-O0-693-106691. 
ID-33-E-158 A\&M. TAN-607 FLOOR PLANS. SHOWS THREE FLOOR LEVELS OF POOL, HOT SHOP, AND WARM SHOP. INCLUDES VIEW OF POOL VESTIBULE, PERSONNEL LABYRINTH, LOCATION OF FLOOR RAILS, AND ROOM NUMBERS OF OFFICE AREAS, LABS, INSTRUMENT ROOMS, AND STAIRWAYS. THIS DRAWING WAS RE-DRAWN TO SHOW AS-BUILT FEATURES IN 1993. RALPH M. PARSONS 902-3-ANP-607-A 96. DATE OF ORIGINAL: DECEMBER 1952. APPROVED BY INEEL CLASSIFICATION OFFICE FOR PUBLIC RELEASE. INEEL INDEX CODE NO. 034-0607-00-693-106748.

ID-33-E-159

A\&M. TAN-607 FLOOR PLAN FOR FIRST FLOOR. SHOWS STEPPED DOOR PLUG DESIGN FROM HOT SHOP INTO SPECIAL SERVICES CUBICLE, CUBICLE WINDOWS, AND OTHER DETAILS. THIS DRAWING WAS RE-DRAWN TO SHOW AS-BUILT CONDITIONS IN 1985. RALPH M. PARSONS 902-3-ANP-607-A 99. DATE OF ORIGINAL: JANUARY 1955. APPROVED BY INEEL CLASSIFICATION OFFICE FOR PUBLIC RELEASE. INEEL INDEX CODE NO. 034-0607-00-693-106751.

ID-33-E-160 A\&M. TAN-607 FIRST FLOOR PLAN FOR COLD ASSEMBLY AREA. SHOWS SPECIAL SOURCE VAULTS, X-RAY ROOM, INSTRUMENT SHOPS, AND POSITIONS OF LARGE MACHINES IN COMPONENT TEST LABORATORY. THIS DRAWING WAS RE-DRAWN TO SHOW CONDITIONS IN 1994. RALPH M. PARSONS 902-3-ANP-607-A 100. DATE OF ORIGINAL: DECEMBER 1952. APPROVED BY INEEL CLASSIFICATION OFFICE FOR PUBLIC RELEASE. INEEL INDEX CODE NO. $034-060-00-693-106752$

ID-33-E-161 A\&M. TAN-607 SECOND FLOOR PLAN FOR COLD ASSEMBLY AREA. METALLURGICAL LAB, CHEMISTRY LAB, NUCLEAR INSTRUMENT LAB, EQUIPMENT ROOMS. RALPH M. PARSONS 902-ANP-607-A 102. DATE: DECEMBER 1952. APPROVED BY INEEL CLASSIFICATION OFFICE FOR PUBLIC RELEASE. INEEL INDEX CODE NO. 034-0607-693-106754.

ID-33-E-162 A\&M. TAN-607 SECOND FLOOR PLAN FOR HOT SHOP. ROOF OF POOL. VIEWING WINDOW LOCATIONS. SPECIAL

EQUIPMENT ROOM. THIS DRAWING WAS RE-DRAWN TO SHOW CONDITIONS IN 1994. RALPH M. PARSONS

902-3-ANP-607-A 101. DATE: DECEMBER 1952. APPROVED BY INEEL CLASSIFICATION OFFICE FOR PUBLIC RELEASE. INEEL INDEX CODE NO. 034-060-00-693-106753.

$\mathrm{ID}-33-\mathrm{E}-163$

A\&M. TAN-607. THIRD FLOOR PLAN FOR HOT SHOP. CRANE CONTROL ROOMS AND THEIR SHIELDING WINDOWS. PLENUM. WALL RACK FOR MANIPULATORS IN HOT SHOP. RALPH M. PARSONS 902-3-ANP-607-A 103. DATE: DECEMBER 1952. 
ID-33-E-164

ID $-33-E-165$

ID $-33-E-166$

ID-33-E-167
APPROVED BY INEEL CLASSIFICATION OFFICE FOR PUBLIC RELEASE. INEEL INDEX NO. 034-0607-00-693-106755.

A\&M. TAN-607 SECTIONS. SECTION A SHOWS VARIABLE ROOF LINES, VARIABLE THICKNESS OF HOT SHOP SHIELD WALLS, RELATIONSHIP OF SUBTERRANEAN POOL TO GRADE. SECTION B SHOWS RELATIVE HEIGHTS OF HOT SHOP FLOOR AND ITS CONTROL GALLERY, POSITION OF BRIDGE CRANES AND MANIPULATOR RAILS. LOCOMOTIVE SERVICE PIT. REFERENT DRAWING IS ID-33-E-158 ABOVE. RALPH M. PARSONS 902-3-ANP-607-A 105. DATE: DECEMBER 1952. APPROVED BY INEEL CLASSIFICATION OFFICE FOR PUBLIC RELEASE. INEEL INDEX CODE NO. 034-0607-00-693-106757.

A\&M. TAN-607. SECTIONS. SECTION C CUTS HOT SHOP ON ITS 160-FOOT EAST/WEST LINE. SHOWS TAPERED SHIELD WALL ON EAST AND WEST FACADES OF BUILDING. RELATIONSHIP BETWEEN HOT SHOP AND SPECIAL EQUIPMENT SERVICE ROOM, CABLE TRACKS FOR OVERHEAD BRIDGE CRANE, LOCATION OF WELL. CONCRETE ROOF BEAMS. SECTION D SHOWS SIMILAR EAST/WEST OF COLD ASSEMBLY ROOM 115 AND ITS BRIDGE CRANE RAIL. SHOWS HEAVY SHIELDING AROUND SPECIAL SERVICES CUBICLE AND HEIGHT OF VIEWING WINDOWS ON EAST AND WEST SIDES. REAR OF BUILDING IS SHOWN IN RELATIONSHIP TO THE RIDGE EAST OF THE BUILDING. REFERENT DRAWING IS ID-33-E-158 ABOVE. RALPH M. PARSONS 902-3-ANP-607-A 106. DATE: DECEMBER 1952. APPROVED BY INEEL CLASSIFICATION OFFICE FOR PUBLIC RELEASE. INEEL INDEX NO. 034-0607-00-693-106758.

A\&M. TAN-607. SECTION VIEWS OF HOT SHOP. SECTION E SHOWS EQUIPMENT AREAS ALONG REAR WALL. SECTION F SHOWS STORAGE POOL CUT ALONG EAST/WEST LINE. ROOF TRUSSES, SHELVES ALONG SIDES OF POOL, DRAIN, AND SUMP. SECTION G CUTS ALONG NORTH/SOUTH TO SHOW CENTERLINE OF TURNTABLES, MANIPULATOR ARMS, O-MAN BRIDGE, CRANE BRIDGE. REFERENT DRAWING IS ID-33-E-158 ABOVE. RALPH M. PARSONS 902-3-ANP-607-A 107. DATE: DECEMBER 1952, BUT AS-BUILT IN 1982. APPROVED BY INEEL CLASSIFICATION OFFICE FOR PUBLIC RELEASE. INEEL INDEX CODE NO. 034-0607-00-693-106759.

A\&M. TAN-607. ELEVATIONS FOR SECOND-PHASE EXPANSION OF A\&M BUILDING. WORK AREAS SOUTH OF THE CARPENTRY SHOP. HIGH-BAY SHOP, DECONTAMINATION ROOM AT SOUTH-MOST END. APPROVED BY INEEL CLASSIFICATION OFFICE FOR PUBLIC RELEASE. RALPH M. 


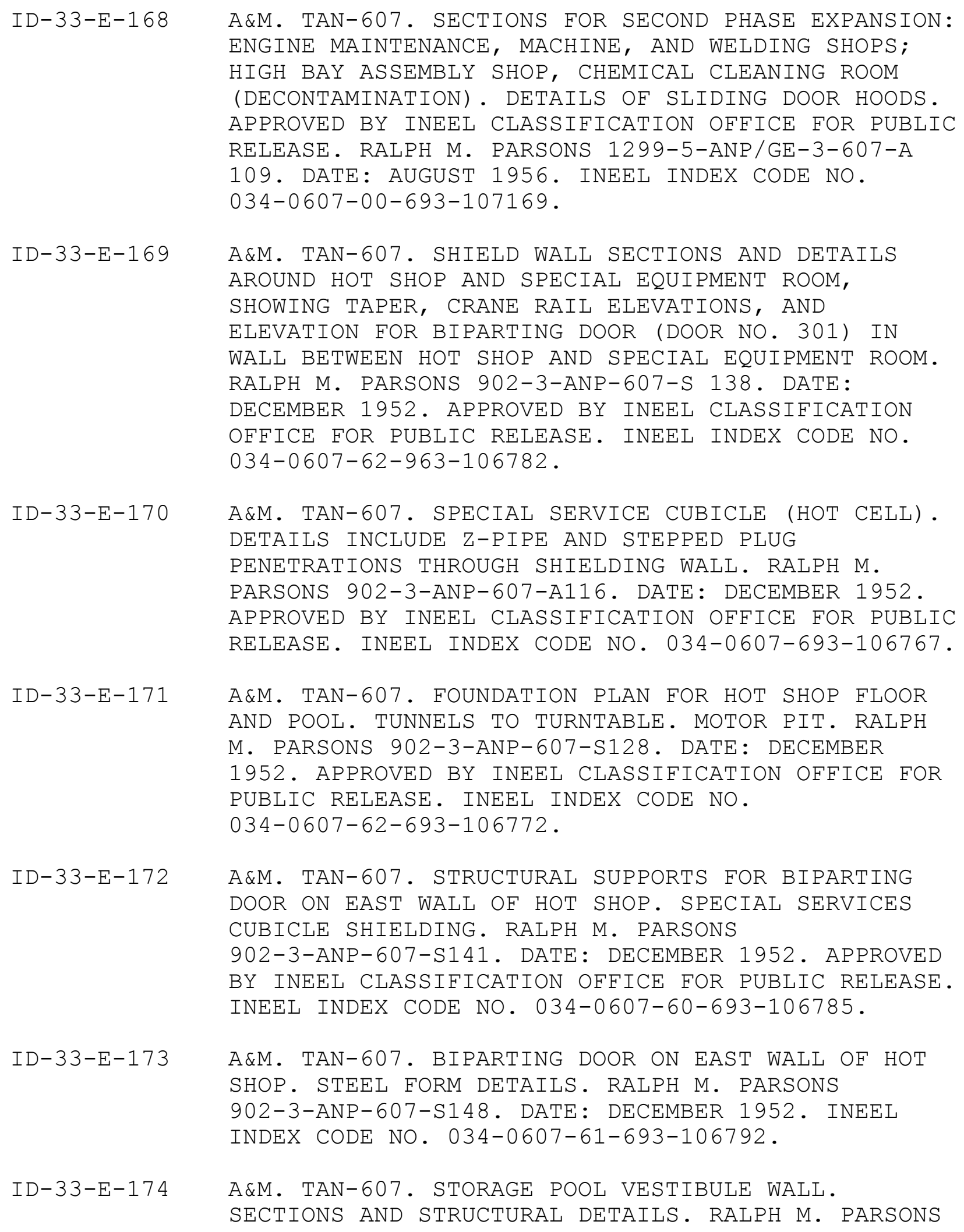




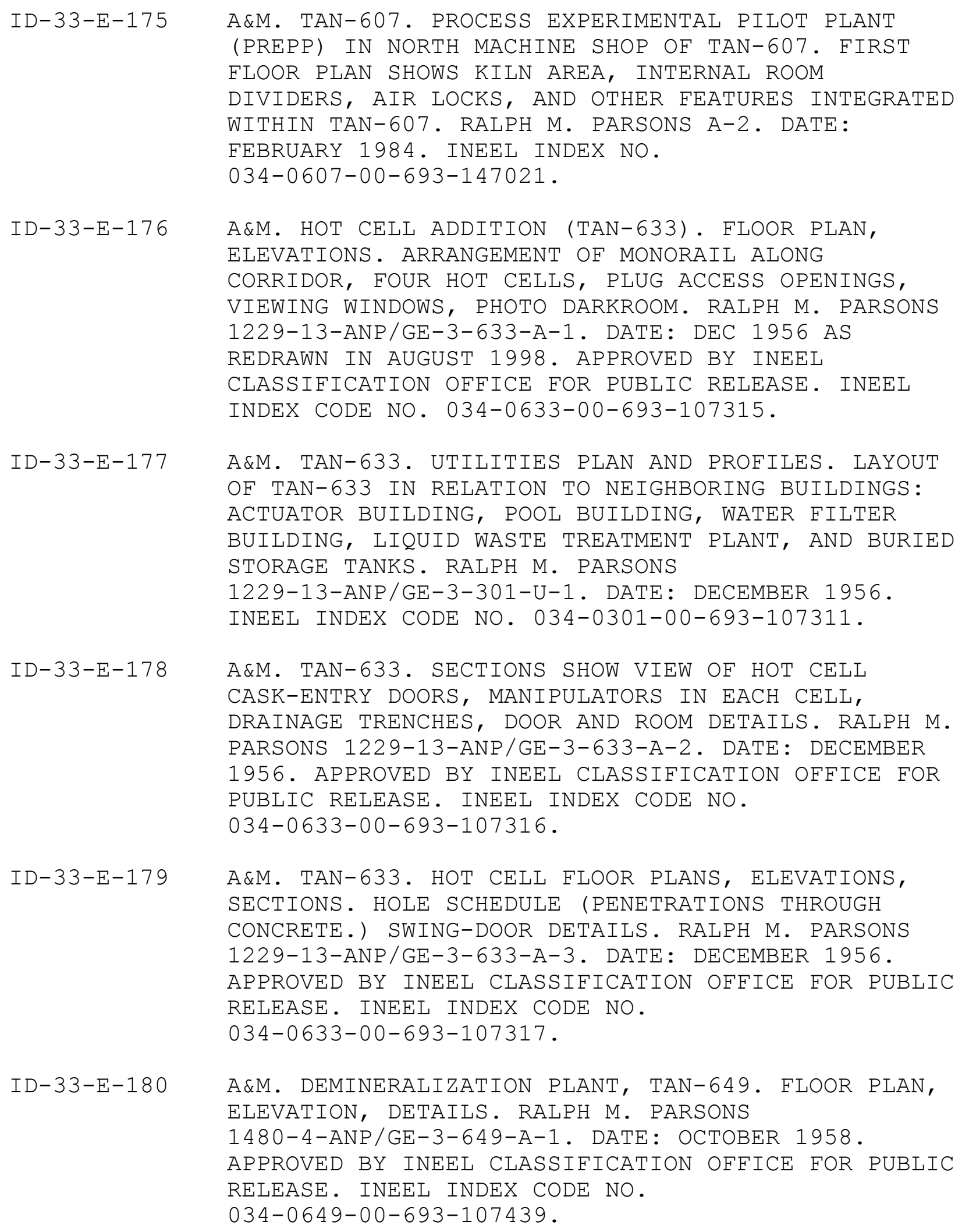


ID-33-E-181 A\&M. DEMINERALIZATION PLANT (TAN-649). STEEL DOOR. RALPH M. PARSONS 1480-L/ANP/GE-3-649-MS-1. DATE : OCTOBER 1958. APPROVED BY INEEL CLASSIFICATION OFFICE FOR PUBLIC RELEASE. INEEL INDEX CODE NO. 034-0649-40-693-107443.

ID-33-E-182 A\&M. RADIOACTIVE PARTS SECURITY STORAGE AREA, TAN-647 AND TAN-648. PLOT PLAN, FENCING DETAILS. RELATIONSHIP TO HOT SHOP AND RAILROAD TURNTABLE. RALPH M. PARSONS 1480-7-ANP/GE-3-102. DATE: NOVEMBER 1958. APPROVED BY INEEL CLASSIFICATION OFFICE FOR PUBLIC RELEASE. INEEL INDEX NO. 034-0100-00-693-107447.

ID-33-E-183 A\&M. RADIOACTIVE PARTS SECURITY STORAGE AREA, HEAT REMOVAL STORAGE CASKS. PLAN, SECTION, AND DETAILS. RALPH M. PARSONS 1480-7 ANP/GE-3-720-S-1. DATE: NOVEMBER 1958. APPROVED BY INEEL CLASSIFICATION OFFICE FOR PUBLIC RELEASE. INEEL INDEX NO. 034-0720-60-693-107459.

ID-33-E-184 A\&M. ACTUATOR BUILDING, TAN-615. FLOOR PLAN, ELEVATIONS, SECTIONS. TEST AND DECONTAMINATION AREAS. PITS. CHANGE ROOM. GENERAL ELECTRIC IDA-615-1070. DATE: DECEMBER 1956. INEEL INDEX NO. 034-0615-00-309-217511.

ID-33-E-185 A\&M. LIQUID WASTE TREATMENT PLANT, TAN-616. PLAN, ELEVATIONS, SECTIONS, AND DETAILS. EVAPORATOR PIT. PUMP ROOM. ROOM NAMES AND NUMBERS. RALPH M. PARSONS 902-3-ANP-616-A 297. DATE: DECEMBER 1952. APPROVED BY INEEL CLASSIFICATION OFFICE FOR PUBLIC RELEASE. INEEL INDEX NO. 034-0616-00-693-106889.

ID-33-E-186 A\&M. OUTSIDE TURNTABLE, TAN-705. STRUCTURAL PLAN AND DETAILS. RALPH M. PARSONS 902-3-ANP-705-S 149. DATE: JANUARY 1953. APPROVED BY INEEL CLASSIFICATION OFFICE FOR PUBLIC RELEASE. INEEL INDEX CODE NO. 034-0705-60-693-106793.

\section{ADMINISTRATIVE COMPLEX}

Photos ID-33-E-187 through ID-33-E-194 were taken of ANP Administrative and Service (ADM) area building TAN-628 prior to demolition. Photographer Mike Crane took photos in March 2004.

ID-33-E-187 ADM. WAREHOUSE BUILDING (TAN-628). CAMERA FACING WEST. OBLIQUE VIEW OF WEST AND NORTH FACADES. INEEL NEGATIVE NO. HD-39-8-2. 
ID-33-E-188 ADM. WAREHOUSE BUILDING (TAN-628) WEST FACADE. CAMERA FACING EAST. INEEL NEGATIVE NO. HD-39-8-1.

ID-33-E-189 ADM. WAREHOUSE BUILDING (TAN-628) SOUTH FACADE. CAMERA FACING WEST. CHANGE HOUSE (TAN-607) IN BACKGROUND. INEEL NEGATIVE NO. HD-39-8-3.

ID-33-E-190 ADM. WAREHOUSE BUILDING (TAN-628) NORTH FACADE. CAMERA FACING SOUTH. INEEL NEGATIVE NO. HD-39-8-4.

ID-33-E-191 ADM. WAREHOUSE BUILDING (TAN-628) EAST FACADE . CAMERA FACING WEST. INEEL NEGATIVE NO. HD-39-9-2.

ID-33-E-192 ADM. WAREHOUSE BUILDING (TAN-628) DETAIL OF LOADING DOCK AT SOUTHEAST CORNER. CAMERA FACING WEST. INEEL NEGATIVE NO. HD-39-9-3.

ID-33-193 ADM. WAREHOUSE BUILDING (TAN-628) INTERIOR OF RECEIVING OFFICE AND HOLDING AREA. INEEL NEGATIVE NO. HD-39-9-1.

ID-33-E-194 ADM. WAREHOUSE BUILDING (TAN-628) INTERIOR DETAIL OF RECEIVING AREA. INEEL NEGATIVE NO. HD-39-9-4 .

Photos ID-33-E-195 through ID-33-E-211 are historic pictures of ANP Administrative buildings. Dates are noted.

ID-33-E-195 ADM. AERIAL VIEW OF ADMINISTRATION AREA. CAMERA FACING WESTERLY. FROM LEFT TO RIGHT IN FOREGROUND: SUBSTATION (TAN-605), WAREHOUSE (TAN-628), GATE HOUSE (TAN-601), ADMINISTRATION BUILDING (TAN-602). LEFT TO RIGHT MIDDLE GROUND: SERVICE BUILDING (TAN-603), WAREHOUSE (LATER KNOWN AS MAINTENANCE SHOP OR CRAFT SHOP, TAN-604), WATER WELL PUMP HOUSES, FUEL TANKS AND FUEL PUMP HOUSES, AND WATER STORAGE TANKS. CHANGE HOUSE (TAN-606) ON NEAR SIDE OF BERM. LARGE BUILDING BEYOND BERM IS A\&M BUILDING, TAN-607. RAILROAD TRACKS BEYOND LEAD FROM (UNSEEN) TURNTABLE TO THE IET. DATE: JUNE 6, 1955. INEEL NEGATIVE NUMBER 13201.

ID-33-E-196 ADM. TANKS: FROM LEFT TO RIGHT: FUEL OIL TANK, FUEL PUMP HOUSE (TAN-611), ENGINE FUEL TANK, WATER PUMP HOUSE, WATER STORAGE TANK. CAMERA FACING NORTHWEST. NOTE EDGE OF SHIELDING BERM AT LEFT OF VIEW. DATE: NOVEMBER 25, 1953. INEEL NEGATIVE NO. 9217 .

ID-33-E-197 ADM. WATER SYSTEM PUMP HOUSE (TAN-610) AND TANK AS COMPLETE. DATE: OCTOBER 10, 1954. INEEL NEGATIVE 
NO. 12580.

ID-33-E-198 ADM. PUMP HOUSE (TAN-612) FOR WELL NO. 1 AS COMPLETED. IT IS IDENTICAL TO PUMP HOUSE (TAN-613) FOR WELL NO. 2, WHICH IS NOT SHOWN IN THIS REPORT. DATE: OCTOBER 19, 1954. INEEL NEGATIVE NO. 12576.

ID-33-E-199 ADM. FUEL TANKS AND FUEL PUMP HOUSE (TAN-611) AS COMPLETE. DATE: OCTOBER 29, 1954. INEEL NEGATIVE NO. 12704 .

ID-33-E-200 ADM. WAREHOUSE (TAN-628) AS IT LOOKED WHEN NEARLY COMPLETE. EAST AND NORTH FACADES. DATE: DECEMBER 20, 1955. INEEL NEGATIVE NO. 55-3557.

ID-33-E-201 ADM. SERVICE BUILDING (TAN-603) AS COMPLETED. CAMERA FACING WESTERLY. DATE: OCTOBER 19, 1954. INEEL NEGATIVE NO. 12578.

ID-33-E-201 ADM. SERVICE BUILDING (TAN-603) INTERIOR. CAFETERIA. DATE: OCTOBER 19, 1954. INEEL NEGATIVE NO. 12581 .

ID-33-E-203 ADM. SERVICE BUILDING (TAN-603) INTERIOR. DISPENSARY. DATE: OCTOBER 19, 1954. INEEL NEGATIVE NO. 12579.

ID-33-E-204 ADM. WAREHOUSE (TAN-604). CONSTRUCTION VIEW OF STRUCTURAL STEEL BEING PLACED FOR ROOF. DATE: OCTOBER 1, 1953. INEEL NEGATIVE NO. 8950.

ID-33-E-205 ADM. WAREHOUSE (TAN-604) AS COMPLETED. CAMERA FACING NORTHWEST. DATE: OCTOBER 19, 1954. INEEL NEGATIVE NO. 12577.

ID-33-E-206 ADM. SUBSTATION (TAN-605) AS COMPLETE. DATE: NOVEMBER 23, 1954. INEEL NEGATIVE NO. 13009.

ID-33-E-207 ADM. CHANGE HOUSE (TAN-606) AS COMPLETED. CAMERA FACING NORTHERLY. NOTE PROXIMITY TO SHIELDING BERM. PART OF HOT SHOP (A\&M BUILDING, TAN-607) AT LEFT OF VIEW BEYOND BERM. DATE: OCTOBER 29, 1954. INEEL NEGATIVE NO. 12705.

ID-33-E-208 ADM. CHANGE HOUSE (TAN-606) INTERIOR. MEN'S SHOWER AND LOCKER ROOM. DATE: OCTOBER 29, 1954. INEEL NEGATIVE NO. 12698.

ID-33-E-209 ADM. ADMINISTRATION BUILDING (TAN-602) UNDER CONSTRUCTION. ROOF DECK BEING PLACED. WATER TANK 
BEYOND AT RIGHT. DATE: 1954. INEEL NEGATIVE NO. 8982 .

ID-33-E-210 ADM. ADMINISTRATION BUILDING (TAN-602) INTERIOR. DRAFTING ROOM IN USE. DATE: JULY 12, 1954. INEEL NEGATIVE NUMBER 11346.

ID-33-E-211 ADM. GATE HOUSE (TAN-601) INTERIOR. TELEPHONE DIAL EQUIPMENT. DATE: JUNE 22, 1954. INEEL NEGATIVE NO. 11019 .

Photos ADM-dr-1 through ADM-dr-10 are architectural drawings of the ANP Administrative and Service area.

ID-33-E-212 ADM. SERVICE BUILDING (TAN-603). ELEVATIONS OF ALL FACADES WITH DOOR DETAILS AND DETAIL OF KITCHEN. SECTION THROUGH GARAGE AREA SHOWS SECOND LEVEL OF STEEL DECKING. EQUIPMENT AND LABORATORY FURNITURE SCHEDULE. RALPH M. PARSONS 902-2-ANP-603-A 44. DATE: DECEMBER 1952. APPROVED BY INEEL CLASSIFICATION OFFICE FOR PUBLIC RELEASE. INEEL INDEX CODE NO. 033-0603-00-693-106719.

ID-33-E-213 ADM. SERVICE BUILDING (TAN-603). FLOOR PLAN. NAMES OF FUNCTIONAL AREAS. RALPH M. PARSONS 902-2-ANY-603-A 43. DATE: DECEMBER 1952. APPROVED BY INEEL CLASSIFICATION OFFICE FOR PUBLIC RELEASE. INEEL INDEX CODE NO. 033-0603-00-693-106718.

ID-33-E-214 ADM. WAREHOUSE (TAN-604). FLOOR PLAN. GENERAL WAREHOUSE AND CHEMICAL STORAGE. RALPH M. PARSONS 902-2-ANP-604-A 55. DATE: DECEMBER 1952. APPROVED BY INEEL CLASSIFICATION OFFICE FOR PUBLIC RELEASE. INEEL INDEX CODE NO. 035-0604-00-693-106727.

ID-33-E-215 ADM. WAREHOUSE (TAN-604). ELEVATIONS AND SECTIONS. RALPH M. PARSONS 902-2-ANP-604-A 56. DATE: DECEMBER 1952. APPROVED BY INEEL CLASSIFICATION OFFICE FOR PUBLIC RELEASE. INEEL INDEX CODE NO. 035-0604-00-693-106728.

ID-33-E-216 ADM. CHANGE HOUSE (TAN-606). ELEVATIONS AND FLOOR PLAN. ROOM NAMES. RALPH M. PARSONS 902-2-ANP-606-A 65. DATE: DECEMBER 1952. INEEL APPROVED BY INEEL CLASSIFICATION OFFICE FOR PUBLIC RELEASE. INDEX CODE NO. 035-0606-00-693-106733.

ID-33-E-217 ADM. WATER SYSTEM PUMP HOUSE (TAN-610). ELEVATIONS, PLAN, AND SECTIONS. RALPH M. PARSONS 902-2-ANP-610-A 74. DATE: FEBRUARY 1952. APPROVED 


$$
\begin{array}{ll}
\text { ID-33-E-218 } & \text { ADM. FUEL PUMP HOUSE (TAN-611). ELEVATIONS, FLOOR } \\
& \text { PLAN. DRAWING INCLUDES ELEVATION AND PLANS FOR } \\
& \text { "H.M." STRUCTURES (HOSE STORAGE?). RALPH M. } \\
& \text { PARSONS 902-2-ANP-611-A 78. DATE: DECEMBER 1952. } \\
& \text { APPROVED BY INEEL CLASSIFICATION OFFICE FOR PUBLIC } \\
& \text { RELEASE. INEEL INDEX CODE NO. } \\
& \text { 035-0611-00-693-106741. } \\
\text { ID-33-E-219 } & \text { ADM. WATER WELL PUMP HOUSES (TAN-612 AND TAN-613). } \\
& \text { PLANS, ELEVATIONS, FLOOR AND OTHER DETAILS. RALPH } \\
& \text { M. PARSONS 902-2-ANP-612-613-A S \& P 82. DATE: } \\
& \text { DECEMBER 1952. APPROVED BY INEEL CLASSIFICATION } \\
& \text { OFFICE FOR PUBLIC RELEASE. INEEL INDEX CODE NO. } \\
& \text { 035-0612-00-693-106743. }
\end{array}
$$

ID-33-E-220 ADM. ADMINISTRATION BUILDING (TAN-602). EARLY ROOM LAYOUT, DOOR AND ROOM SCHEDULES. RALPH M. PARSONS 902-2-ANP-602-A 31. DATE: DECEMBER 1952. APPROVED BY INEEL CLASSIFICATION OFFICE FOR PUBLIC RELEASE. INEEL INDEX CODE NO. 033-0602-00-693-106710.

ID-33-E-221 ADM. ADMINISTRATION BUILDING (TAN-602). ELEVATIONS, SECTIONS, DETAILS. SHOWS AREAS THAT WERE SOON REMODELED OR ADDED ONTO. RALPH M. PARSONS 902-2-ANP-602-A 32. DATE AUGUST 1955. APPROVED BY INEEL CLASSIFICATION OFFICE FOR PUBLIC RELEASE . INEEL INDEX CODE NO. 033-0602-00-693-106711.

ID-33-E-222 A\&M. TECHNICAL SERVICE LABORATORY IN ADMINISTRATION BUILDING (TAN-602). FLOOR PLAN, RECEPTION DESK, DOOR AND FINISH SCHEDULES. RALPH M. PARSONS 1480-12-ANP/GE-3-602-A-1. INEEL INDEX CODE NO. 033-0602-00-693-107488.

ID-33-E-223 A\&M. GATE HOUSE (TAN-601). PLAN, ELEVATIONS, SECTIONS, DETAILS. SHOWS EXPANDED BUILDING AS ATTACHED TO TAN-602. RALPH M. PARSONS 902-2-ANP-601-A 22. DATE: DECEMBER 1952. INEEL INDEX CODE NO. 033-0602-00-693-106704.

ID-33-E-224 A\&M. WAREHOUSE (TAN-628). FLOOR AND FOUNDATION PLAN. ELEVATIONS. RALPH M. PARSONS 772-ANP-628-A-S-1. DATE JULY 1955. INEEL INDEX CODE NO. 033-0628-00-693-106683.

ID-33-E-225 A\&M. PLOT PLAN OF ADMINISTRATION AND A\&M AREAS. 
SHOWS RELATIONSHIPS AMONG ADMINISTRATION BUILDINGS AND TO A\&M BUILDING (TAN-607), RAILROAD TURNTABLE. RALPH M. PARSONS 902-2\&3-ANP-U 3. DATE: DECEMBER 1952. INEEL INDEX CODE NO. 032-0100-00-693-106690.

LOW POWER TEST COMPLEX

Photos ID-33-E-226 through ID-33-E-256 are of the ANP Low Power Test Facility and Shield Test Facility prior to demolition in 2004. Both were part of the Low Power Test (LPT) Complex. They were taken by photographer Mike Crane in March 2004.

ID-33-E-226 LPT. LOW POWER ASSEMBLY AND TEST BUILDING (TAN-640). CAMERA FACING WEST. ROLLUP DOORS TO EACH TEST CELL FACE EAST. CONCRETE WALLS POURED IN PLACE. APPARATUS AT RIGHT OF VIEW WAS PART OF A POST-ANP PROGRAM. INEEL NEGATIVE NO. HD-40-1-1.

ID-33-E-227 LPT. LOW POWER ASSEMBLY AND TEST BUILDING (TAN-640). CAMERA FACING WEST. DETAIL OF ROLLUP DOORS. INEEL NEGATIVE NO. HD-40-1-4.

ID-33-E-228 LPT. LOW POWER ASSEMBLY AND TEST BUILDING (TAN-640) SOUTH FACADE. CAMERA FACING NORTH. NOTE ONE-STORY PUMICE BLOCK CORRIDOR, WHICH PROVIDED INSIDE ACCESS BETWEEN CONTROL BUILDING (AT LEFT EDGE OF VIEW) AND TEST CELL. INEEL NEGATIVE NO. $\mathrm{HD}-40-1-2$.

ID-33-E-229 LPT. LOW POWER ASSEMBLY AND TEST BUILDING (TAN-640) OBLIQUE OF NORTH AND EAST FACADES. OUTDOOR SEMISCALE TANKAGE IN FOREGROUND. INEEL NEGATIVE NO. HD-40-1-3.

ID-33-E-230 LPT. LOW POWER TEST CELL IN TAN-640. INTERIOR OF NORTH CELL. CAMERA FACES SOUTHWEST. CORNER SHOWS SOUTH AND WEST WALLS. MEZZANINE PROVIDED ACCESS TO EXPERIMENTS. INEEL NEGATIVE NO. HD-40-2-1.

ID-33-E-231 LPT. LOW POWER TEST CELL IN TAN-640. INTERIOR OF NORTH CELL. CAMERA FACING NORTHWEST. CORNER SHOWS WEST AND NORTH WALLS. INEEL NEGATIVE NO. $\mathrm{HD}-40-2-2$.

ID-33-E-232 LPT. LOW POWER TEST CONTROL BUILDING (TAN-641) CONTEXTUAL VIEW. OBLIQUE VIEW OF WEST AND SOUTH FACADES. ACCESS CORRIDOR ALONG SOUTH SIDE. NOTE STEPPED CONCRETE WALL OF TEST CELL BUILDING. INEEL NEGATIVE NO. HD-40-3-1. 
LPT. LOW POWER TEST CONTROL BUILDING (TAN-641). CLOSER VIEW OF SOUTH FACADE ACCESS CORRIDOR AND STEPPED CONCRETE WALL. CAMERA FACING NORTHEAST. INEEL NEGATIVE NO. HD-40-3-3.

ID-33-E-234 LPT. LOW POWER TEST CONTROL BUILDING (TAN-641) EAST FACADE. SIGN SAYS " ENERGY AND SYSTEMS TECHNOLOGY LABORATORY, INEL" (POST-ANP USE) • CAMERA FACING WEST. INEEL NEGATIVE NO. HD-40-3-2.

ID-33-E-235 LPT. LOW POWER TEST CONTROL BUILDING (TAN-641) NORTH FACADE. CAMERA FACING SOUTH. INEEL NEGATIVE $\mathrm{NO}$. $\mathrm{HD}-40-3-4$.

ID-33-E-236 LPT. LOW POWER TEST CONTROL BUILDING (TAN-641) SOUTH FACADE AND ACCESS CORRIDOR TO TEST CELL. INEEL NEGATIVE NO. HD-40-4-2.

ID-33-E-237 LPT. LOW POWER TEST CONTROL BUILDING (TAN-641) INTERIOR. CAMERA FACING WEST. OFFICE AREA. (OPEN) DOOR TO SPECIAL SOURCE VAULT AT CENTER OF VIEW. INEEL NEGATIVE NO. HD-40-4-1.

ID-33-E-238 LPT. LOW POWER TEST CONTROL BUILDING (TAN-641) INTERIOR. CAMERA FACING NORTHEAST AT WHAT REMAINS OF CONTROL ROOM CONSOLE. CUT IN WALL AT RIGHT OF VIEW SHOWS WEST WALL OF NORTHERN TEST CELL. INEEL NEGATIVE NO. HD-40-4-4 .

ID-33-E-239 LPT. LOW POWER TEST CONTROL BUILDING (TAN-641) INTERIOR. CAMERA FACING EAST INTO EQUIPMENT ROOM. FLOORING HAS BEEN REMOVED. INEEL NEGATIVE NO. $\mathrm{HD}-40-4-3$.

ID-33-E-240 LPT. SHIELD TEST FACILITY CONTEXTUAL VIEW OF POOL ROOM (TAN-646) WEST FACADE. CAMERA FACING EAST. FROM LEFT TO RIGHT: WATER STORAGE TANK; HIGH BAY POOL ROOM; EQUIPMENT AND EQUIPMENT EXTENSION ON LOWER LEVEL; HELIUM WING AND STACK. NOTE EXCLUSION FENCE IN FOREGROUND. INEEL NEGATIVE NO. HD-40-8-2.

ID-33-E-241 LPT. SHIELD TEST FACILITY ASSEMBLY AND TEST BUILDING (TAN-646). CAMERA FACING NORTHWEST FOR OBLIQUE VIEW. FROM LEFT TO RIGHT: EAST FACADE OF EBOR COOLING STACK AND HELIUM WING; SOUTH FACADE OF POOL FACILITY; SOUTH FACADE OF CONTROL BUILDING (TAN-645) . INEEL NEGATIVE NO. HD-40-7-2.

ID-33-E-242 LPT. SHIELD TEST FACILITY ASSEMBLY AND TEST BUILDING (TAN-646). EAST FACADE OF EBOR HELIUM 


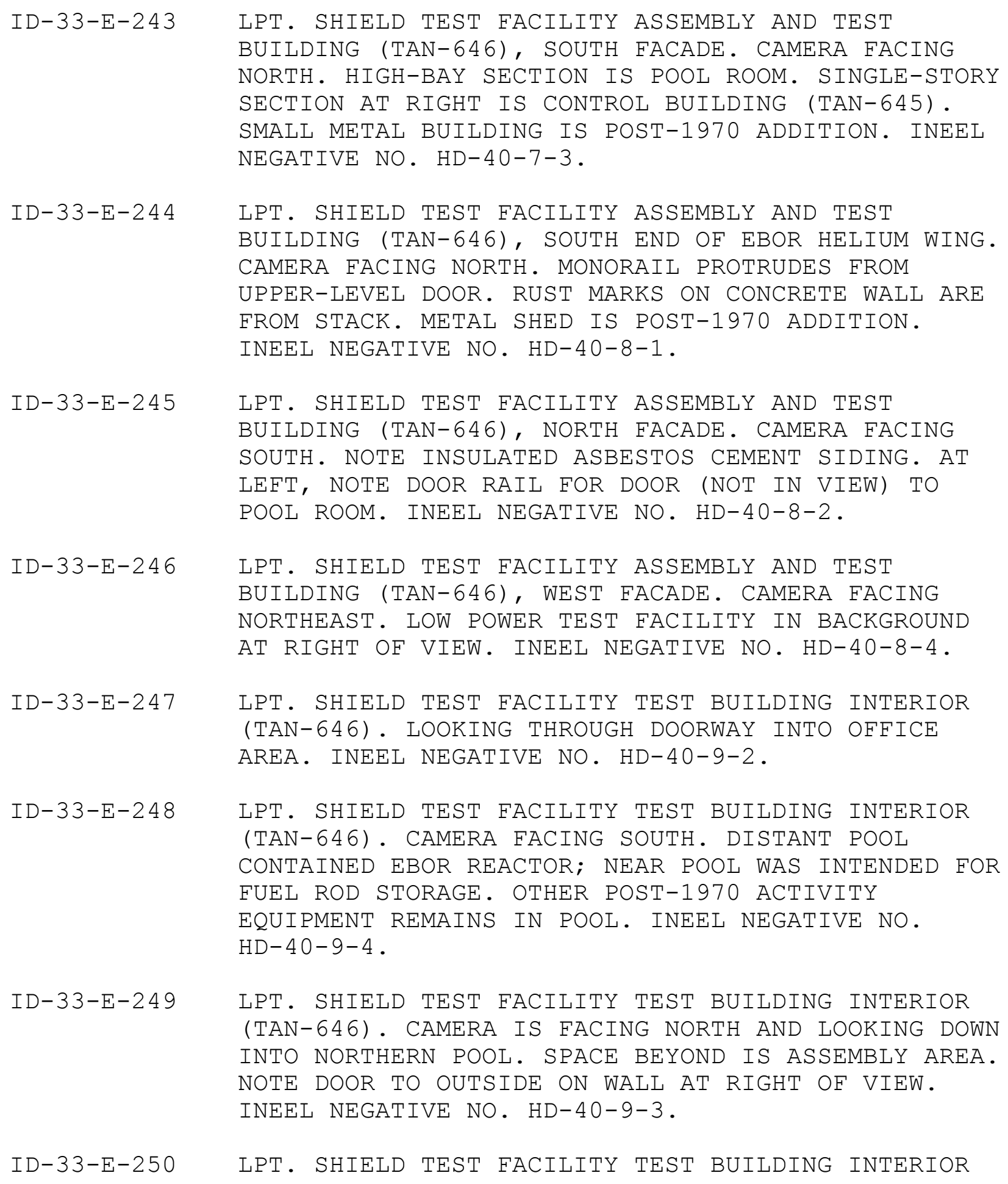




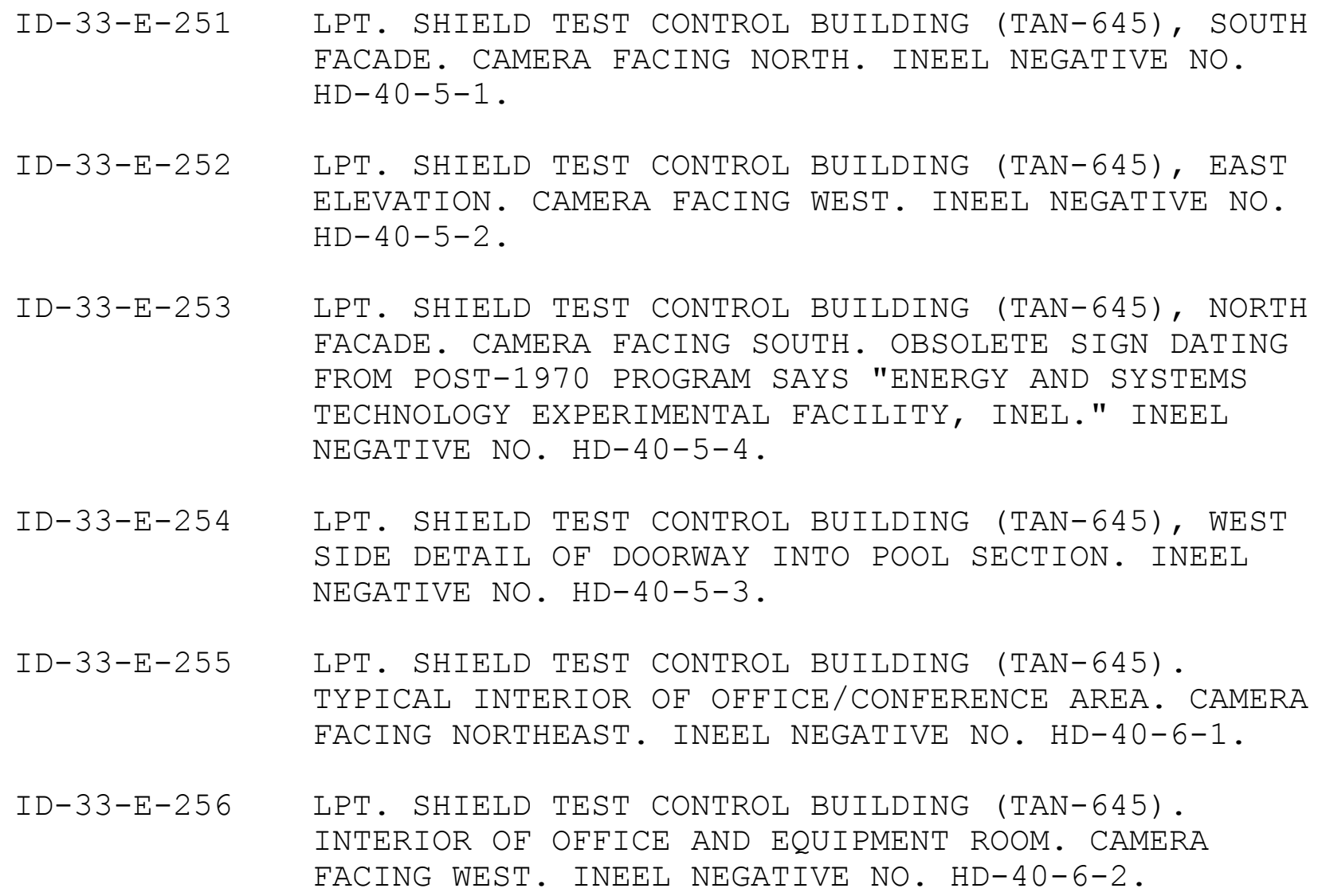

Photos ID-33-E-257 through ID-33-E-289 are historical photographs of the Low Power Test facility (TAN-640 and TAN-641); and the Shield Test Facility and its later adaption for the Experimental Beryllium Oxide Reactor (EBOR, TAN-645 and TAN-646). Date and photographers are noted.

ID-33-E-257 LPT. AERIAL OF LOW POWER TEST (TAN-640 AND -6416) AND SHIELD TEST (TAN-645 AND -646) FACILITIES. CAMERA FACING SOUTHWEST. ROAD AT UPPER RIGHT LEADS TO ADMINISTRATIVE AREA. PHOTOGRAPHER: JACK L. ANDERSON. DATE: MARCH 27, 1959. INEEL NEGATIVE NO. 59-1644.

ID-33-E-258 LPT. AERIAL OF LOW POWER TEST FACILITY (TAN-640 AND -641) AND SHIELD TEST FACILITY (TAN-645 AND -646). CAMERA FACING SOUTH. LOW POWER REACTOR CELLS AT LEFT, THEN ONE-STORY CONTROL BUILDING; DIAGONAL FENCE; SHIELD TEST CONTROL BUILDING, THEN (HIGH-BAY) POOL ROOM. IN FOREGROUND ARE ELECTRICAL 


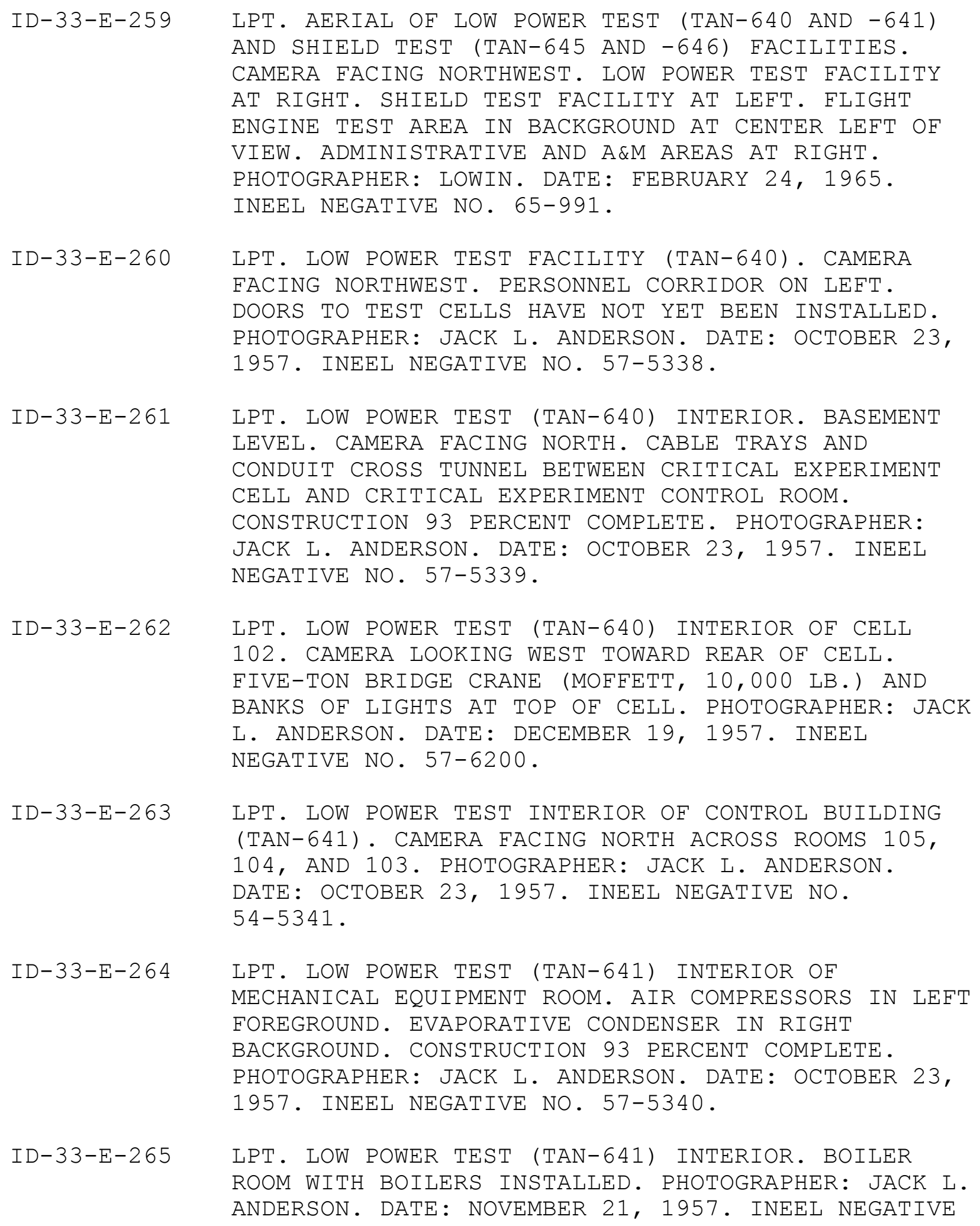


NO. $57-5884$.

ID-33-E-266 LPT. LOW POWER TEST (TAN-641) INTERIOR. HEATING AND VENTILATING PNEUMATIC AND ELECTRIC CONTROL PANEL. CONTRACT NEARLY COMPLETE. PHOTOGRAPHER: JACK L. ANDERSON. DATE: DECEMBER 19, 1957. INEEL NEGATIVE NO . 57-6198.

ID-33-E-267 LPT. LOW POWER TEST (TAN-641) INTERIOR. CAMERA IS INSIDE SPECIAL SOURCE VAULT AND FACING SOUTHEAST. INTERIOR GRILL DOOR IS CLOSED; OUTER STEEL DOOR IS OPEN. PHOTOGRAPHER: JACK L. ANDERSON. DATE: DECEMBER 19, 1957. INEEL NEGATIVE NO. 57-6197.

ID-33-E-268 LPT. SHIELD TEST FACILITY (TAN-646) INTERIOR. POOL ROOM NEARLY COMPLETE. FIFTY-TON BRIDGE CRANE IS READY FOR OPERATION. WATER FILLS FOREGROUND POOL. PHOTOGRAPHER: M. HOLMES. DATE: JUNE 23, 1959. INEEL NEGATIVE NO. 59-3263.

ID-33-E-269 LPT. SHIELD TEST FACILITY (TAN-646) INTERIOR OF POOL ROOM. CAMERA FACING SOUTH. NOTE STEEL BEAMS ALONG SIDE WALLS. PHOTOGRAPHER: JACK L. ANDERSON. DATE: APRIL 21, 1959. INEEL NEGATIVE NO. 59-2130.

ID-33-E-270 LPT. SHIELD TEST FACILITY (TAN-646) INTERIOR. CONSTRUCTION WORKER APPLIES CAULKING COMPOUND TO JOINT BETWEEN STAINLESS STEEL WEIR AND CONCRETE. PHOTOGRAPHER: JACK L. ANDERSON. DATE: MARCH 6, 1959. INEEL NEGATIVE NO. 59-1099.

ID-33-E-271 LPT. SHIELD TEST FACILITY (TAN-646) INTERIOR. WATER TREATMENT ROOM CONTAINS WATER SOFTENERS, DEIONIZERS, AND DISPLAY PANEL. NOTE METAL CEILING AND WALLS. PHOTOGRAPHER: JACK L. ANDERSON. DATE: FEBRUARY 20, 1959. INEEL NEGATIVE NO. 59-856

ID-33-E-272 LPT. SHIELD TEST FACILITY (TAN-645) INTERIOR. MECHANICAL EQUIPMENT ROOM WITH AIRWASHER AND REFRIGERATION COMPRESSOR. PHOTOGRAPHER: JACK L. ANDERSON. DATE: FEBRUARY 20, 1959. INEEL NEGATIVE NO. 59-855.

ID-33-E-273 LPT. SHIELD TEST FACILITY (TAN-645) INTERIOR. MECHANICAL EQUIPMENT ROOM WITH SWITCHGEAR AND CONTROL BOARDS. PHOTOGRAPHER: JACK L. ANDERSON. DATE: FEBRUARY 20, 1959, INEEL NEGATIVE NO. $59-858$.

ID-33-E-274 LPT. SHIELD TEST FACILITY (TAN-645) INTERIOR. 


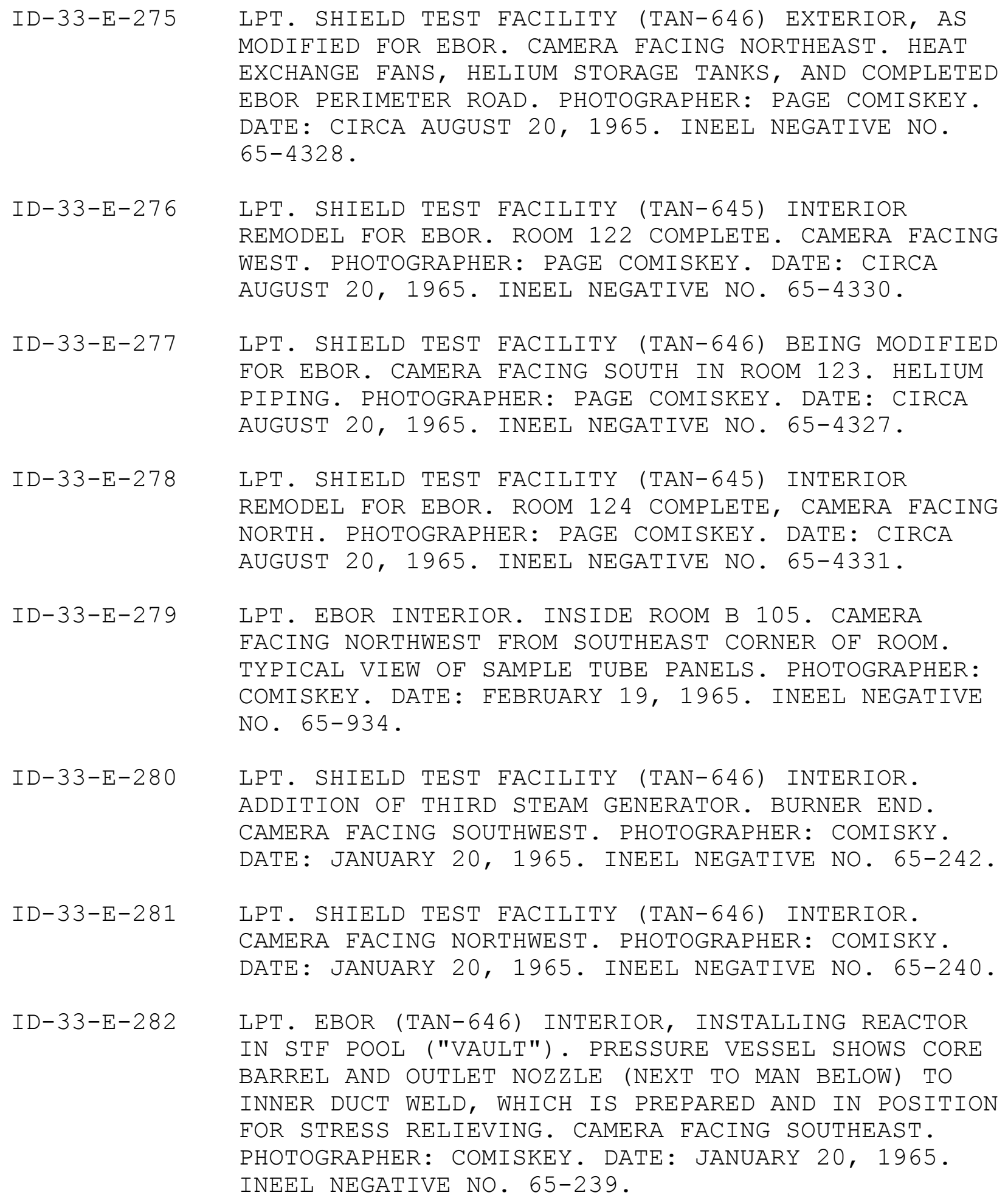




\begin{tabular}{|c|c|}
\hline$I D-33-E-283$ & $\begin{array}{l}\text { LPT. EBOR (TAN-646) REACTOR VESSEL, FLOW } \\
\text { DISTRIBUTION TANK. OUTLET NOZZLE ON SIDE OF VESSEL } \\
\text { WILL BE CONNECTED TO COOLANT DUCT. PHOTOGRAPHER: } \\
\text { LOWIN. DATE: JANUARY 20, } 1965 \text {. INEEL NEGATIVE NO. } \\
65-237 .\end{array}$ \\
\hline$I D-33-E-284$ & $\begin{array}{l}\text { LPT. EBOR (TAN-646) REACTOR VESSEL, DISTRIBUTION } \\
\text { TANK. VIEW OF TOP OF TANK, WITH COOLANT PORT } \\
\text { BELOW. PHOTOGRAPHER: LOWIN. DATE: JANUARY 20, } \\
\text { 1965. INEEL NEGATIVE NO. 65-236. }\end{array}$ \\
\hline$D-33-E-285$ & $\begin{array}{l}\text { LPT. EBOR REACTOR VESSEL IN TAN } 646 \text {. PRESSURE } \\
\text { VESSEL HEAD BEING INSTALLED IN VAULT. REFUELING } \\
\text { PORT EXTENSION (RIGHT) AND CONTROL ROD NOZZLES } \\
\text { (CENTER). CAMERA FACING NORTHWEST. PHOTOGRAPHER: } \\
\text { COMISKEY. DATE: JANUARY 20, 1965. INEEL NEGATIVE } \\
\text { NO. 65-241. }\end{array}$ \\
\hline$D-33-E-286$ & $\begin{array}{l}\text { LPT. EBOR (TAN-646) REACTOR VESSEL. TOP VIEW OF } \\
\text { REFLECTOR SUPPORT TANK. PHOTOGRAPHER: COMISKEY. } \\
\text { DATE: JANUARY 20, 1965. INEEL NEGATIVE NO. 65-234. }\end{array}$ \\
\hline$I D-33-E-287$ & $\begin{array}{l}\text { LPT. EBOR (TAN-646) REACTOR VAULT. CONCRETE BLOCKS } \\
\text { FOR REACTOR SHIELDING GOING INTO SHIELD TEST } \\
\text { FACILITY POOL. PHOTOGRAPHER: COMISKEY. DATE: } \\
\text { FEBRUARY 19, 1965. INEEL NEGATIVE NO. 65-933. }\end{array}$ \\
\hline$I D-33-E-288$ & $\begin{array}{l}\text { LPT. EBOR (TAN-646) INTERIOR. CAMERA FACING WEST } \\
\text { AND DOWN INTO REACTOR VAULT. SHOWS SHUT-DOWN } \\
\text { STRUCTURAL STEEL SUPPORT AND PRESSURE VESSEL HEAD. } \\
\text { PHOTOGRAPHER: COMISKEY. DATE: APRIL 20, } 1965 . \\
\text { INEEL NEGATIVE NO. 65-2192. }\end{array}$ \\
\hline$D-33-E-289$ & $\begin{array}{l}\text { LPT. EBOR (TAN-646) INTERIOR. CAMERA IS FACING } \\
\text { NORTH AND DOWN INTO REACTOR VAULT. VIEW SHOWS } \\
\text { PORTION OF THE LEAD SHUTDOWN SHIELD, PRESSURE } \\
\text { VESSEL THIMBLES, AND REFUELING PORTS MOUNTED ON } \\
\text { PRESSURE VESSEL HEAD. CONCRETE SHIELDING BELOW. } \\
\text { PHOTOGRAPHER: FARMER. DATE: MAY 24, 1965. INEEL } \\
\text { NEGATIVE NO. 65-2739. }\end{array}$ \\
\hline
\end{tabular}

Photos ID-33-E-290 through ID-33-E-307 are architectural drawings of the Low Power Test and Shield Test Facility buildings constructed during the Aircraft Nuclear Propulsion program. This group also includes modification drawings of the shield Test Facility for the EBOR project.

ID-33-E-290 LPT. PLOT PLAN AND SITE LAYOUT. INCLUDES SHIELD TEST POOL/EBOR FACILITY (TAN-645 AND -646) LOW POWER TEST BUILDING (TAN-640 AND -641), WATER 


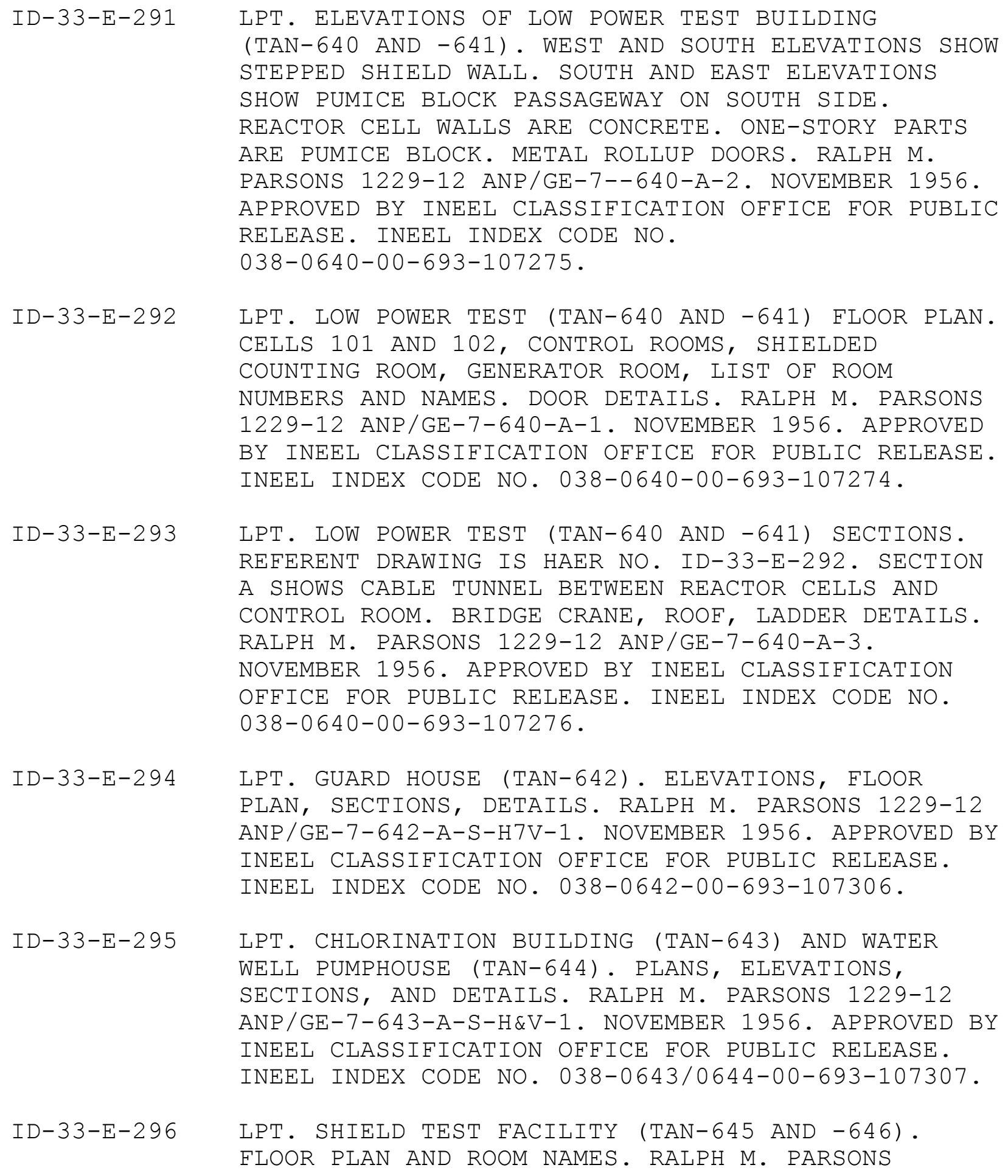




$$
\begin{aligned}
& \text { ID-33-E-297 LPT. SHIELD TEST FACILITY (TAN-645 AND -646). } \\
& \text { ELEVATIONS SHOW THREE TYPES OF SIDING: ASBESTOS } \\
& \text { CEMENT, PUMICE BLOCK, CONCRETE. RALPH M. PARSONS } \\
& \text { 1229-17 ANP/GE-6-645-A-3. APRIL 1957. APPROVED BY } \\
& \text { INEEL CLASSIFICATION OFFICE FOR PUBLIC RELEASE. } \\
& \text { INEEL INDEX CODE NO. 037-0645/0646-00-693-107349. } \\
& \text { ID-33-E-298 LPT. SHIELD TEST FACILITY (TAN-645 AND -646). } \\
& \text { BASEMENT AND SUB-BASEMENT PLAN. STAIRWAY PLANS AND } \\
& \text { DETAILS. RALPH M. PARSONS 1229-17 } \\
& \text { ANP/GE-6-645-A-2. APRIL 1957. APPROVED BY INEEL } \\
& \text { CLASSIFICATION OFFICE FOR PUBLIC RELEASE. INEEL } \\
& \text { INDEX CODE NO. 037-0645/0646-00-693-107348. } \\
& \text { ID-33-E-299 LPT. SHIELD TEST FACILITY (TAN-645 AND -646). } \\
& \text { SECTIONS SHOW RELATIONSHIPS AMONG CONTROL ROOMS, } \\
& \text { COUPLING STATION, COUNTING ROOMS, POOLS, EQUIPMENT } \\
& \text { ROOMS, DATA ROOM AND OTHER AREAS. RALPH M. PARSONS } \\
& \text { 1229-17 ANP/GE-6-645-A-4. APRIL 1957. APPROVED BY } \\
& \text { INEEL CLASSIFICATION OFFICE FOR PUBLIC RELEASE. } \\
& \text { INEEL INDEX CODE NO. 037-0645/0646-00-693-107350. } \\
& \text { ID-33-E-300 LPT. SHIELD TEST FACILITY (TAN-645 AND -646). } \\
& \text { CALIBRATION LAB SHIELD DOOR. RALPH M. PARSONS } \\
& \text { 1229-17 ANP/GE-6-645-MS-1. APRIL 1957. APPROVED BY } \\
& \text { INEEL CLASSIFICATION OFFICE FOR PUBLIC RELEASE. } \\
& \text { INEEL INDEX CODE NO. 037-0645-40-693-107369. } \\
& \text { ID-33-E-301 LPT. SHIELD TEST FACILITY (TAN-646). FLOOR PLAN } \\
& \text { FOR WATER TREATMENT ROOM ON WEST FACADE, TANK AND } \\
& \text { FILTER LOCATIONS IN BASEMENT ALONG SERVICE TUNNEL } \\
& \text { AND IN COUPLING STATION. RALPH M. PARSONS 1229-17 } \\
& \text { ANP/GE-6-646-P-2. APRIL 1957. INEEL INDEX CODE NO. } \\
& \text { 037-0645/0646-51-693-107387. }
\end{aligned}
$$

ID-33-E-302 LPT. SHIELD TEST FACILITY (TAN-646). SECTIONS AND DETAILS OF WATER MANAGEMENT AREAS. RALPH M. PARSONS 1229-17 ANP/GE-6-646-P-3. APRIL 1957. APPROVED BY INEEL CLASSIFICATION OFFICE FOR PUBLIC RELEASE. INEEL INDEX CODE NO. 037-0646-51-693-107388.

ID-33-E-303 LPT. EBOR PROJECT (TAN-645 AND -646). NEW PUMPHOUSE BUILT IN 1965 AS TAN-652. FLOOR PLAN, ELEVATIONS, DETAILS. KAISER ENGINEERS 
EBOR/GA-646-A-104. DATE: MAY 1963. INEEL INDEX CODE NO. 037-0652-00-486-119053.

ID-33-E-304 LPT. EBOR (TAN-646). FLOOR PLAN FOR NEW HELIUM MANAGEMENT WING. DETAIL OF SAMPLE VAULT AND BASEMENT SWITCH ROOM. KAISER ENGINEERS EBOR/GA-646-A-101. DATE: MAY 1963. INEEL INDEX CODE NO. 037-0646-00-486-119115.

ID-33-E-305 LPT. EBOR (TAN-646). REACTOR VAULT AND POOL ARRANGEMENT. STEPPED ARRANGEMENT OF SHIELDING BLOCKS. FLOOR PLAN, ELEVATION OF REACTOR, AND DETAILS. KAISER ENGINEERS EBOR/GA-646-P-102. DATE: MAY 1963. INEEL INDEX CODE NO. 037-0646-00-486-119116.

ID-33-E-306 LPT. EBOR (TAN-646). ELEVATIONS. CONCRETE HELIUM WING. EXHAUST STACK. MONORAIL DOOR 42. KAISER ENGINEERS EBOR/GA-646-A-102. DATE: MAY 1963. INEEL INDEX CODE NO. 037-0646-00-486-119051.

ID-33-E-307 LPT. EBOR (TAN-646). SECTIONS. REACTOR SHIELDING PROFILE. BELOW-GRADE PIPE TUNNEL, DUCTS, ROOMS . KAISER ENGINEERS EBOR/GA-646-A-103. DATE: MAY 1963. INEEL INDEX CODE NO. 037-0646/0645-00-486-119052.

FLIGHT ENGINE TEST COMPLEX

Photographs ID-33-E-308 through ID-33-E-315 are drawings of the Control and Equipment Building (TAN-630) and other buildings associated with the ANP Hangar (TAN-629) at the Flight Engine Test (FET) Complex. Large-format photos, historic photos, and drawings of the ANP Hangar (TAN-629) can be found in HAER Report ID-33-A. Please consult the Photo Index of that report. The following architectural drawings record facilities that were not included in HAER Report ID-33-A.

ID-33-E-308 FET. CONTROL AND EQUIPMENT BUILDING, TAN-630. MAIN FLOOR PLAN. CONTROL ROOM. ROOM NUMBERS AND FUNCTIONS. RALPH M. PARSONS 1229-2-ANP/GE-5-630-A-2. DATE: MARCH 1957. APPROVED BY INEEL CLASSIFICATION OFFICE FOR PUBLIC RELEASE. INEEL INDEX CODE NO. 036-0630-00-693-107081.

ID-33-E-309 FET. CONTROL AND EQUIPMENT BUILDING (TAN-630). BASEMENT FLOOR PLAN. TUNNEL TO HANGAR (TAN-629) • ELECTRICAL AND CHEMICAL SERVICES. RALPH M. PARSONS 
1229-2-ANP/GE-5-630-A-1. DATE: MARCH 1957.

APPROVED BY INEEL CLASSIFICATION OFFICE FOR PUBLIC RELEASE. INEEL INDEX CODE NO. 036-0630-00-693-107080.

ID-33-E-310 FET. CONTROL AND EQUIPMENT BUILDING (TAN-630). SECTIONS. EARTH COVER. SHIELDED ACCESS ENTRIES FOR PERSONNEL AND VEHICLES. RALPH M. PARSONS 1229-2-ANP/GE-5-630-A-3. DATE: MARCH 1957.

APPROVED BY INEEL CLASSIFICATION OFFICE FOR PUBLIC RELEASE. INEEL INDEX CODE NO. 036-0630-00-693-107082.

ID-33-E-311 FET. CONTROL AND EQUIPMENT BUILDING (TAN-630). SECTIONS. RALPH M. PARSONS 1229-2-ANP/GE-5-630-A-4. DATE: MARCH 1957.

APPROVED BY INEEL CLASSIFICATION OFFICE FOR PUBLIC RELEASE. INEEL INDEX CODE NO. 036-0630-00-693-107083.

ID-33-E-312 FET. CONTROL AND EQUIPMENT BUILDING (TAN-630). EAST ELEVATION AND SECTION. SHIELDED ROADWAY AND PERSONNEL ENTRANCES. RALPH M. PARSONS 1229-2-ANP/GE-5-630-A-5. DATE: MARCH 1957. APPROVED BY INEEL CLASSIFICATION OFFICE FOR PUBLIC RELEASE. INEEL INDEX CODE NO. 036-0630-00-693-107084.

ID-33-E-313 FET. TANK BUILDING, TAN-631. ELEVATIONS, SECTIONS, DETAILS. TANK PADS AND SADDLES. RALPH M. PARSONS 1229-2-ANP/GE-5-631-A-1. DATE: MARCH 1957. APPROVED BY INEEL CLASSIFICATION OFFICE FOR PUBLIC RELEASE. INEEL INDEX CODE NO. 036-0631-00-693-107142.

ID-33-E-314 FET. CHLORINATION BUILDING, TAN-637. ELEVATIONS, SECTION. RALPH M. PARSONS 1229-2-ANP/GE-5-637-A-S-H\&V-1. DATE: MARCH 1957. APPROVED BY INEEL CLASSIFICATION OFFICE FOR PUBLIC RELEASE. INEEL INDEX CODE NO. 036-0637-00-693-107148.

ID-33-E-315 FET. EXHAUST DUCT AND STACK. PLAN, ELEVATION, FOUNDATION, DETAILS. RALPH M. PARSONS 1480-10 ANP/GE-5-716-S-3. DATE: FEBRUARY 1959. APPROVED BY INEEL CLASSIFICATION OFFICE FOR PUBLIC RELEASE. INEEL INDEX CODE NO. 036-0716-00-693-107474.

Photos ID-33-E-316 through ID-33-E-354 were taken in 2004 of the Loss of Fluid Test (LOFT) facility prior to demolition. The 
photographer was Mike Crane. Dates were March and May, 2004. ID-33-E-316 LOFT. CONTEXTUAL VIEW OF SOUTH SIDE OF SHIELDED ROADWAY (TAN-719). LOFT CONTAINMENT BUILDING (TAN-650) AND STACK AT LEFT EDGE OF VIEW. CAMERA FACING NORTHWEST. DATE: MARCH 2004. INEEL NEGATIVE NO. HD-39-3-1.

ID-33-E-317 LOFT. CONTEXTUAL VIEW OF NORTH SIDE OF SHIELDED ROADWAY (TAN-719) AS IT LOOKED DURING LOFT USE OF FET FACILITIES. CAMERA FACING SOUTHWEST. SIGN OVER DOOR SAYS, "CONTAINED TEST FACILITY." NOTE EARTH SHIELDING. DATE: MARCH 2004. INEEL NEGATIVE NO. HD-39-3-2.

ID-33-E-318 LOFT. ENTRY TO SHIELDED ROADWAY. CAMERA FACING WEST. NOTE LANDSCAPING WITH ASPENS AND OTHER NON-DESERT SHRUBS. DATE: MARCH 2004. INEEL NEGATIVE NO. HD-39-3-3.

ID-33-E-319 LOFT. CONTEXTUAL VIEW OF EXHAUST STACK. CAMERA FACING NORTHEAST. AT RIGHT OF VIEW IS COMPRESSOR BUILDING (TAN-637). DATE: MARCH 2004. INEEL NEGATIVE NO. HD-39-6-1.

ID-33-E-320 LOFT. CONTEXTUAL VIEW OF PERSONNEL ENTRANCE. CAMERA FACING NORTH. HANGAR (TAN-629) AT FAR LEFT. SHIELDED CONTROL ROOM (TAN-629) TO LEFT, CONTAINMENT BUILDING (TAN-650) TO RIGHT. DATE: MAY 2004. INEEL NEGATIVE NO. HD-39-19-2.

ID-33-E-321 LOFT. CONTAINMENT BUILDING ENTRY, AN ADAPTED USE OF TAN-624, WHICH ORIGINATED AS THE MOBILE TEST BUILDING FOR THE ANP PROGRAM. CAMERA FACING NORTH. NOTE FOUR-RAIL TRACK ENTERED BUILDING. STACK AT RIGHT OF VIEW. DATE: MARCH 2004. INEEL NEGATIVE NO. HD-39-4-1.

ID-33-E-322 LOFT. CAMERA FACING NORTHWEST. CONTAINMENT ENTRY (TAN-624) AND LOFT CONTAINMENT BUILDING (TAN-650). DATE: MARCH 2004. INEEL NEGATIVE NO. HD-39-4-2.

ID-33-E-323 LOFT. CAMERA FACING EAST SIDE OF CONTAINMENT ENTRY (TAN-624) AND ITS ATTACHMENT TO CONTAINMENT BUILDING (TAN-650). DATE: MARCH 2004. INEEL NEGATIVE NO. HD-39-4-3.

ID-33-E-324 LOFT. CAMERA FACING WEST SIDE OF CONTAINMENT ENTRY (TAN-624) AND CONTAINMENT DOME (TAN-650). DATE: MARCH 2004. INEEL NEGATIVE NO. HD-39-4-4. 


\begin{tabular}{|c|c|}
\hline$-33-E-325$ & $\begin{array}{l}\text { LOFT. OBLIQUE VIEW WITH HANGAR (TAN-629), } \\
\text { CONTAINMENT ENTRY (TAN-624), AND CONTAINMENT DOME } \\
\text { (TAN-650) IN VIEW. CAMERA FACING NORTHWEST. DATE: } \\
\text { MAY 2004. INEEL NEGATIVE NO. HD-39-19-4. }\end{array}$ \\
\hline$I D-33-E-326$ & $\begin{array}{l}\text { LOFT. WEST SIDE OF CONTAINMENT BUILDING AND DOME } \\
\text { (TAN-650). CAMERA IS ATOP EARTH-SHIELDED CONTROL } \\
\text { BUILDING (TAN-630), FACING EAST. VERTICAL } \\
\text { STRUCTURE AT RIGHT OF VIEW (WITH LIGHT AFFIXED) IS } \\
\text { WEST END OF RAILROAD DOOR SHROUD. DATE: MAY 2004. } \\
\text { INEEL NEGATIVE NO. HD-39-19-1. }\end{array}$ \\
\hline$I D-33-E-327$ & $\begin{array}{l}\text { LOFT, TAN-650. CAMERA FACING SOUTHEAST. FROM LEFT } \\
\text { TO RIGHT: STACK IN DISTANCE, PRE-AMP WING, DOME, } \\
\text { NORTH SIDE OF LOFT "SERVICE BUILDING." NOTE POURED } \\
\text { CONCRETE WALL OF PRE-AMP WING ON LOWER SECTION; } \\
\text { PUMICE BLOCK ABOVE. DATE: MAY } 2004 \text {. INEEL NEGATIVE } \\
\text { NO. HD-39-19-3. }\end{array}$ \\
\hline$I D-33-E-328$ & $\begin{array}{l}\text { LOFT, TAN-650. CLOSER VIEW OF SERVICE BUILDING } \\
\text { (ALSO CALLED LOFT ENCLOSURE BUILDING). CAMERA } \\
\text { FACING WEST. DATE: MAY } 2004 \text {. INEEL NEGATIVE NO. } \\
\text { HD-39-20-2. }\end{array}$ \\
\hline$I D-33-E-329$ & $\begin{array}{l}\text { LOFT, TAN-650. CLOSER VIEW OF SERVICE BUILDING AND } \\
\text { EXTERIOR PIPING. CAMERA FACING EAST. DATE: MAY } \\
\text { 2004. INEEL NEGATIVE NO. HD-39-20-4. }\end{array}$ \\
\hline$I D-33-E-330$ & $\begin{array}{l}\text { LOFT, TAN-650. VIEW OF PRE-AMP BUILDING, CAMERA } \\
\text { FACING SOUTH. DATE: MAY } 2004 \text {. INEEL NEGATIVE NO. } \\
\text { HD-39-20-1. }\end{array}$ \\
\hline$I D-33-E-331$ & $\begin{array}{l}\text { LOFT, TAN-650. DETAILS OF HEATING AND VENTILATING } \\
\text { SYSTEM. CAMERA FACING SOUTH. HANGAR AT RIGHT OF } \\
\text { VIEW BEYOND SHIELDED CONTROL BUILDING. DATE: MAY } \\
2004 \text {. INEEL NEGATIVE NO. HD-39-20-3. }\end{array}$ \\
\hline$I D-33-E-332$ & $\begin{array}{l}\text { LOFT. INTERIOR VIEW OF ENTRY TO REACTOR BUILDING, } \\
\text { TAN-650. CAMERA IS INSIDE ENTRY (TAN-624) AND } \\
\text { FACING NORTH. AT FAR END OF DOMED CHAMBER ARE } \\
\text { PENETRATIONS IN WALL FOR ELECTRICAL AND OTHER } \\
\text { CONNECTIONS. REACTOR AND OTHER EQUIPMENT HAS BEEN } \\
\text { REMOVED. DATE: MARCH 2004. INEEL NEGATIVE NO. } \\
\text { HD-39-5-1. }\end{array}$ \\
\hline$I D-33-E-333$ & $\begin{array}{l}\text { LOFT. INTERIOR VIEW OF ENTRY (TAN-624) ROLLUP } \\
\text { DOOR. CAMERA IS INSIDE ENTRY BUILDING FACING } \\
\text { SOUTH. ROLLUP DOOR WAS A MODIFICATION OF THE } \\
\text { ORIGINAL ANP DOOR ARRANGEMENT. DATE: MARCH } 200\end{array}$ \\
\hline
\end{tabular}


INEEL NEGATIVE NO. HD-39-5-2.

ID-33-E-334 LOFT, TAN-650. DETAIL VIEW OF RAILROAD DOOR. CAMERA FACES EAST AND EDGE OF DOOR. FLOOR SLAB SLIDES OUT OF THE WAY WHEN DOOR IS TO CLOSE. TAN-624 IS TO RIGHT; LOFT REACTOR CHAMBER IS TO LEFT. DATE: MAY 2004. INEEL NEGATIVE NO. $\mathrm{HD}-39-16-1$.

ID-33-E-335 LOFT, TAN-650. DETAIL OF RAILROAD DOOR. CAMERA FACING NORTHEASTERLY INTO REACTOR CHAMBER. DATE: MAY 2004. INEEL NEGATIVE NO. HD-39-16-2.

ID-33-E-336 LOFT, TAN-650. REACTOR CHAMBER DETAIL. CAMERA FACING SOUTHEASTERLY TOWARD RAILROAD DOOR AND CONTAINMENT ENTRY (TAN-624). LIGHTS STRUNG ALONG WALL. DEMOLITION HAS PROGRESSED; MOST EQUIPMENT IS GONE. REACTOR WAS POSITIONED AT ROUND SPOT AT RIGHT OF VIEW. DATE: MAY 2004. INEEL NEGATIVE NO. HD-39-17-1.

ID-33-E-337 LOFT, TAN-650. INTERIOR AIRLOCK DOOR ON REACTOR FLOOR. CAMERA IS ON WEST SIDE OF AIRLOCK AND FACES SOUTHEAST INTO REACTOR CHAMBER. PHOTO SHOWS BOTH EDGES OF AIRLOCK. CONTROLS AND PRESSURIZATION EQUIPMENT ON AIRLOCK WALL. METAL PLATE FLOOR. DATE: MAY 2004. INEEL NEGATIVE NO. HD-39-17-2.

ID-33-E-338 LOFT, TAN-650. INTERIOR AIRLOCK DOOR. CAMERA FACES NORTHEAST TOWARDS REACTOR CHAMBER. BOTH DOORS OF AIRLOCK ARE OPEN AND IN VIEW. NOTE WOODEN STEPS. DATE: MAY 2004. INEEL NEGATIVE NO. HD-39-17-3.

ID-33-E-339 LOFT, TAN-650. INTERIOR TAKEN WITHIN REACTOR CHAMBER. CAMERA FACING WESTERLY TOWARD AIRLOCK. DATE: MAY 2004. INEEL NEGATIVE NO. HD-39-18-2.

ID-33-E-340 LOFT, TAN-650. INTERIOR, REACTOR CHAMBER. DETAIL VIEW OF CAPPED PENETRATIONS IN NORTH WALL OF CHAMBER AND PIPING ARRAY. NOTE TERMINUS OF RAIL TRACK ON FLOOR. DATE: MAY 2204. INEEL NEGATIVE NO. $\mathrm{HD}-39-18-4$.

ID-33-E-341 LOFT, TAN-650. INTERIOR, REACTOR CHAMBER. CAMERA FACING SOUTHERLY INTO CONTAINMENT ENTRY (TAN-624). DOOR VERTICAL CLEARANCE IS 33 FEET. RAILROAD DOOR IS IN OPEN POSITION (IE, UNSEEN) DATE: MAY 2004. INEEL NEGATIVE NO. HD-39-18-1. 


\begin{tabular}{|c|c|}
\hline$D-33-E-342$ & $\begin{array}{l}\text { LOFT, TAN-650. INTERIOR, CAMERA FACES UPWARD } \\
\text { TOWARD APEX OF DOME. BRIDGE CRANE RIDES CIRCULAR } \\
\text { RAIL PLACED AT TANGENT WHERE DOME MEETS WALL. } \\
\text { DATE: MAY 2004. INEEL NEGATIVE NO. HD-39-18-3. }\end{array}$ \\
\hline$I D-33-E-343$ & $\begin{array}{l}\text { LOFT. INTERIOR, CONTROL ROOM IN CONTROL BUILDING } \\
\text { (TAN-630). CAMERA FACING NORTH. SIGN SAYS, "THIS } \\
\text { CONTROL CONSOLE IS PARTIALLY ACTIVE. DO NOT } \\
\text { OPERATE ANY SWITCH HANDLE WITHOUT AUTHORIZATION." } \\
\text { DATE: MAY } 2004 \text {. INEEL NEGATIVE NO. HD-39-14-3. }\end{array}$ \\
\hline$I D-33-E-344$ & $\begin{array}{l}\text { LOFT. CONTROL ROOM DETAIL IN CONTROL BUILDING } \\
(\text { TAN-630). CAMERA FACING NORTHWEST. DATE: MAY } \\
2004 \text {. INEEL NEGATIVE NO. HD-39-13-2. }\end{array}$ \\
\hline$I D-33-E-345$ & $\begin{array}{l}\text { LOFT. INTERIOR OF VISITORS' ROOM IN CONTROL } \\
\text { BUILDING (TAN-630), TYPICALLY OCCUPIED DURING } \\
\text { TESTS. INDICATOR DISPLAY ALLOWED OBSERVERS TO } \\
\text { WATCH PROGRESS OF EXPERIMENT. DATE: MAY } 2004 . \\
\text { INEEL NEGATIVE NO. HD-39-14-1. }\end{array}$ \\
\hline$I D-33-E-346$ & $\begin{array}{l}\text { LOFT. INTERIOR DETAIL OF CONTROL BUILDING } \\
(\text { TAN-630) VISITORS' ROOM SHOWING INDICATOR } \\
\text { DISPLAY. "ECC" REFERS TO "EMERGENCY CORE COOLING." } \\
\text { DATE: MAY } 2004 \text {. INEEL NEGATIVE NO. HD-39-14-4. }\end{array}$ \\
\hline$I D-33-E-347$ & $\begin{array}{l}\text { LOFT, TAN-630. INTERIOR DETAIL OF SHIELD DOOR AT } \\
\text { END OF CORRIDOR ON GROUND LEVEL AND WEST OF } \\
\text { CONTROL ROOM. SEPARATES CONTROL BUILDING FROM } \\
\text { HANGAR. CAMERA FACING WEST. DATE: MAY } 2004 \text {. INEEL } \\
\text { NEGATIVE NO. HD-39-14-2. }\end{array}$ \\
\hline$I D-33-E-348$ & $\begin{array}{l}\text { LOFT. INTERIOR DETAIL IN BASEMENT LEVEL OF CONTROL } \\
\text { BUILDING (TAN-630). ENTRANCE TO PERSONNEL TUNNEL } \\
\text { WHICH CONNECTS CONTROL AND HANGAR (TAN-629) } \\
\text { BUILDINGS. CAMERA FACING SOUTHEAST. COMPARE WITH } \\
\text { CONSTRUCTION PHOTO NOS. ID-33-E-381 AND } \\
\text { ID-33-E-382. DATE: MAY 2004. INEEL NEGATIVE NO. } \\
\text { HD-39-13-1. }\end{array}$ \\
\hline$I D-33-E-349$ & $\begin{array}{l}\text { LOFT. INTERIOR IN BASEMENT OF CONTROL BUILDING } \\
\text { (TAN-630). FOREGROUND AREA (WITH SQUARE-PATTERN } \\
\text { FLOOR) WAS LOFT BREAKROOM (ANP "EMERGENCY } \\
\text { KITCHEN"). THREE SAMPLE MONITORING STATIONS ON } \\
\text { WALL AT LEET OF CENTER OF VIEW. CORRIDOR ON RIGHT } \\
\text { FACES EAST. NOTE CONDUIT ALONG WALL ON RIGHT. } \\
\text { DATE: MAY 2004. INEEL NEGATIVE NO. HD-39-13-3. }\end{array}$ \\
\hline$I D-33-E-350$ & $\begin{array}{l}\text { LOFT. BOILER ROOM IN LOWER LEVEL OF CONTROL } \\
\text { BUILDING }(\text { TAN-630). CAMERA FACES EAST. DATE: MAY }\end{array}$ \\
\hline
\end{tabular}


2004. INEEL NEGATIVE NO. HD-39-13-4.

ID-33-E-351 LOFT. BASEMENT LEVEL OF LOFT REACTOR BUILDING (TAN-650), SHOWING AIRLOCK. CAMERA FACES

SOUTHEAST. AIRLOCK LEADS TO HEAVILY SHIELDED AREA JUST BELOW REACTOR CHAMBER. NOTE RADIATION HAZARD NOTICES. DATE: MAY 2004. INEEL NEGATIVE NO. HD-39-15-1.

ID-33-E-352 LOFT. BASEMENT LEVEL (TAN-650). DETAIL IN ROOM 201 OF PIPING ON NORTH WALL. DATE: MAY 2004. INEEL NEGATIVE NO. HD-39-15-2.

ID-33-E-353 LOFT. BASEMENT LEVEL (TAN-650). VIEW FROM WEST END OF SHIELDED ROADWAY TOWARDS EAST END (ENTRANCE) OF ROADWAY. CAMERA IS IN TURNAROUND AREA. DATE: MAY 2004. INEEL NEGATIVE NO. HD-39-15-3.

ID-33-E-354 LOFT. DETAIL IN BASEMENT (TAN-650). RADIATION HAZARD WARNING LIGHTS (RED, AMBER, GREEN) IN TURNAROUND AREA. CAMERA FACING WEST. DATE: MAY 2004. INEEL NEGATIVE NO. HD-39-15-4.

Photos ID-33-E-355 through ID-33-E-372 are historical photos of the Loss of Fluid Test (LOFT) facility. Dates are noted.

ID-33-E-355 LOFT. AERIAL CONTEXTUAL VIEW OF CONTAINMENT BUILDING (TAN-650) SITE UNDER CONSTRUCTION. CAMERA FACING WESTERLY. LEFT TO RIGHT: ANP HANGAR (TAN-629), ANP CONTROL BUILDING UNDER EARTHEN SHIELD (TAN-630), CIRCULAR EXCAVATION FOR LOFT'S SUBSURFACE LEVELS AND CATCH BASIN, AND FOUNDATIONS FOR ACCESSORIES TO LOFT BUILDING WEST, NORTH, AND EAST OF CIRCULAR CONTAINMENT STRUCTURE. NOTE EXPOSED PERSONNEL ENTRANCE (JUST LEFT OF CRANE) . DATE: 1967. INEEL NEGATIVE NO. 67-2213.

ID-33-E-356 LOFT. AERIAL CONTEXTUAL VIEW OF CONTAINMENT BUILDING (TAN-650) UNDER CONSTRUCTION. CAMERA FACING EAST. HANGAR IS AT BOTTOM OF VIEW. NOTE TEMPORARY REMOVAL OF EARTH SHIELD ON COVERED ROADWAY AT TOP LEFT OF VIEW. RAILROAD TIES STACKED UP AT RIGHT EDGE OF VIEW. DATE: 1967. INEEL NEGATIVE NO. 67-5027.

ID-33-E-357 LOFT. CONTAINMENT BUILDING (TAN-650) ON THE DAY THE RAILROAD DOOR WAS LIFTED INTO PLACE. CAMERA FACING NORTHEAST. NOTE PERSONNEL ACCESS AT LEFT EDGE OF VIEW. DATE: 1967. INEEL NEGATIVE NO. $70-4141$. 
LOFT. CONTAINMENT BUILDING (TAN-650) WITH FOUR-RAIL TRACKS IN PLACE. STACK HAS BEEN ERECTED. CURVED SHROUD OVER DOORWAY AND TO THE RIGHT IS WEATHER PROTECTION FOR RAILROAD DOOR SEEN IN HAER PHOTO ID-33-E-367. MOTOR-OPERATED DOOR ROLLS ON WHEELS TO OPEN AND CLOSE. SERVICE PORTIONS OF CONTAINMENT BUILDING CAN BE SEEN AT REAR OF DOME ON LEFT AND RIGHT. CAMERA FACING NORTH. DATE: 1973. INEEL NEGATIVE NO. 73-1600.

ID-33-E-359

LOFT. CONTAINMENT BUILDING (TAN-650) DETAIL. CAMERA FACING EAST. SERVICE BUILDING CORNER IS AT LEFT OF VIEW ABOVE PERSONNEL ACCESS. ROUND FEATURE AT LEFT OF DOME IS TANK THAT WILL CONTAIN BORATED WATER. METAL STACK AT RIGHT OF VIEW. DATE: 1973. INEEL NEGATIVE NO. 73-1085.

ID-33-E-360 LOFT. REAR OF LOFT CONTAINMENT BUILDING (TAN-650). BORATED WATER TANK IS AT TOP. NOTE LADDER FOR ACCESS TO TOP OF DOME. CAMERA FACING SOUTHEAST. DATE: 1973. INEEL NEGATIVE NO. 73-1643.

ID-33-E-361 LOFT. REACTOR APPARATUS LEAVES A\&M BUILDING (TAN-607) . SHIELDED LOCOMOTIVE HAS AEROJET LOGO, WHICH REPLACED OLD GENERAL ELECTRIC LOGO, PULLS REACTOR FROM ASSEMBLY SHOP ON DOLLY. CAMERA FACING EASTERLY. DATE: 1973. INEEL NEGATIVE NO. 73-3700.

ID-33-E-362 LOFT. REACTOR ARRIVES AT CONTAINMENT BUILDING (TAN-650), NOW BEING PUSHED BY LOCOMOTIVE. CAMERA FACING NORTHERLY. NOTE "HELLO DOLLY" AND "PWR MTA NO. 1" (PRESSURIZED WATER REACTOR MOBILE TEST ASSEMBLY) SIGNS. DATE: 1973. INEEL NEGATIVE NO. 73-3710.

ID-33-E-363 LOFT. REACTOR SUPPORT APPARATUS INSIDE CONTAINMENT BUILDING (TAN-650). CAMERA IS ON CRANE RAIL LEVEL AND FACING NORTHERLY. VIEW SHOWS TOP TWO BANKS OF ROUND CONDUIT OPENINGS ON WALL FOR ELECTRICAL AND OTHER CONNECTIONS TO CONTROL ROOM. LADDERS AND PLATFORMS PROVIDE ACCESS TO REACTOR INSTRUMENTATION. NOTE HATCH IN FLOOR AND DRAIN AT EDGE OF FLOOR NEAR WALL. DATE: 1974. INEEL NEGATIVE NO. 74-219.

$I D-33-E-364$

LOFT. MOBILE TEST BUILDING (TAN-624) IS RECYCLED FROM ANP PROGRAM FOR PLACEMENT BEFORE LOFT CONTAINMENT BUILDING DOOR. IT HAS NOT YET BEEN CONNECTED TO CONTAINMENT BUILDING. NOTE BORATED WATER TANK AT RIGHT OF DOME. NARROW, VERTICAL 


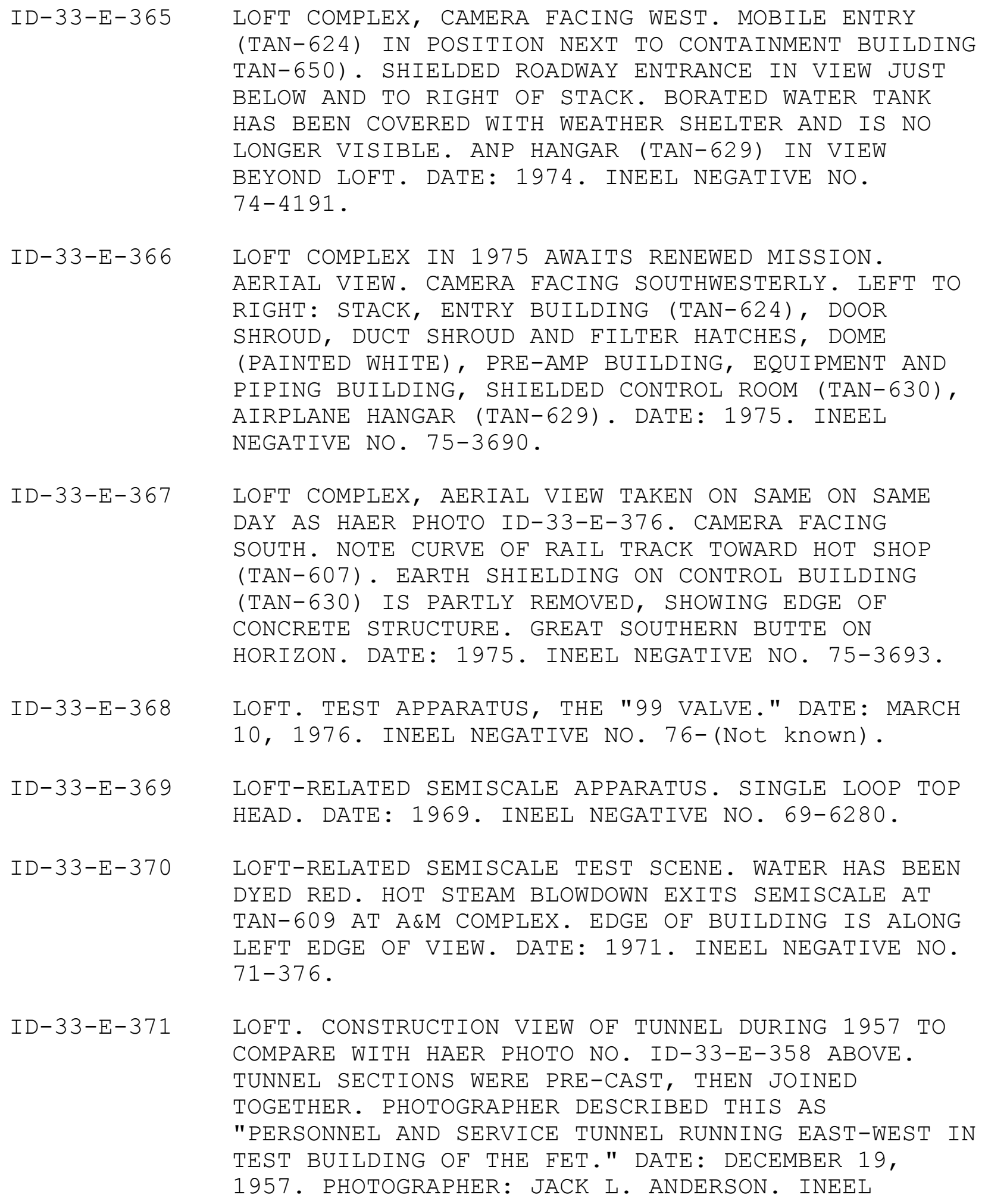

ID-33-E-371 LOFT. CONSTRUCTION VIEW OF TUNNEL DURING 1957 TO COMPARE WITH HAER PHOTO NO. ID-33-E-358 ABOVE. TUNNEL SECTIONS WERE PRE-CAST, THEN JOINED TOGETHER. PHOTOGRAPHER DESCRIBED THIS AS "PERSONNEL AND SERVICE TUNNEL RUNNING EAST-WEST IN TEST BUILDING OF THE FET." DATE: DECEMBER 19, 1957. PHOTOGRAPHER: JACK L. ANDERSON. INEEL 
NEGATIVE NO. 57-6206.

ID-33-E-372 LOFT/FET COMPLEX. CONSTRUCTION VIEW OF ABUTMENT

FOOTINGS FOR ARCHES OF HANGAR (TAN-629). TUNNELS

BETWEEN BASEMENT OF HANGAR AND CONTROL BUILDING (TAN-630) HAD TO FIT BETWEEN ARCHES. (NOTE

CONCRETE WORK TAKING PLACE AT HOLE AT LOWER EDGE

OF VIEW. THIS PHOTO MAY DOCUMENT UNEXPECTED BUBBLE IN UNDERLYING LAVA ROCK. IT WAS PUMPED FULL OF CONCRETE AND A FOOTING MADE. SOURCE: INTERVIEW WITH JOHN DECLUE). DATE: DECEMBER 19, 1957. PHOTOGRAPHER: JACK L. ANDERSON. INEEL NEGATIVE NO. 57-6203.

Photos ID-33-E-373 to ID-33-E-384 are architectural drawings of Loss of Fluid Test (LOFT) facilities at Test Area North's FET complex.

ID-33-E-373 LOFT. CONTAINMENT AND SERVICE BUILDING (TAN-650) BASEMENT FLOOR PLAN. BASEMENT AIR LOCK, SHIELDED ROADWAY, SERVICE AREAS, CONNECTION TO CONTROL BUILDING. KAISER ENGINEERS 6413-11-STEP/LOFT-650-A-1. DATE: OCTOBER 1964. INEEL INDEX CODE NO. 036-650-00-416-122213.

ID-33-E-374 LOFT. CONTAINMENT AND SERVICE BUILDING (TAN-650) GROUND FLOOR PLAN. PENETRATIONS IN DOME WALL. SHIELDED PERSONNEL MAZE AT AIRLOCK DOOR. REACTOR CHAMBER FLOOR HATCHES AND HOLDDOWNS. RAILS IN CONCRETE FLOOR. KAISER ENGINEERS 6413-11-STEP/LOFT-650-A-2. DATE: OCTOBER 1964. INEEL INDEX CODE NO. 036-650-00-486-122214.

ID-33-E-375 LOFT, TAN-650. SERVICE BUILDING PRE-AMP TOWER, TOP THREE FLOORS. FLOOR PLAN, CABLE MAZES, DUCT LABYRINTH. BORATED WATER TANK ENCLOSURE ON ROOF. KAISER ENGINEERS 6413-11-STEP/LOFT-650-A-3. DATE: OCTOBER 1964. INEEL INDEX CODE NO. 036-650-00-486-122215.

ID-33-E-376 LOFT. CONTAINMENT AND SERVICE BUILDING (TAN-650) • SECTION THROUGH EAST/WEST AXIS OF BUILDING AS VIEWED FROM THE SOUTH. SHOWS BASEMENT AND GRADE LEVELS OF CONTAINMENT BUILDING, CONNECTION TO CONTROL ROOM ON WEST SIDE, AIR FILTER VAULTS, AND DUCT ENCLOSURE FOR AIR EXHAUST SYSTEM. KAISER ENGINEERS 6413-11-STEP/LOFT-650-A-4. DATE: OCTOBER 1964. INEEL INDEX CODE NO. 036-650-00-486-122216.

ID-33-E-377 LOFT. CONTAINMENT AND SERVICE BUILDING (TAN-650) . 
$I D-33-E-378$

SECTION THROUGH NORTH/SOUTH AXIS. SHOWS BASEMENT AND FOUR ADDITIONAL LEVELS OF PRE-AMP TOWER, SHIELDED ROADWAY, CHAMBERS BELOW REACTOR FLOOR, RAILROAD DOOR, SUMPS, SHIELDING. SECTION C SHOWS BASEMENT SUMPS AND CHAMBERS BELOW REACTOR FLOOR. KAISER ENGINEERS 6413-11-STEP/LOFT-650-A-5. DATE: OCTOBER 1964. INEEL INDEX CODE NO. 036-650-00-486-122217.

LOFT. CONTAINMENT AND SERVICE BUILDING (TAN-650) . SECTION THROUGH EAST/WEST AXIS OF BUILDING AS VIEWED FROM THE NORTH. SHOWS STEEL LADDER TO TOP OF DOME, GABLE ROOF OF BORATED WATER TANK ENCLOSURE, PUMICE BLOCK SIDING OF PRE-AMP TOWER, METAL SIDING OF DUCT ENCLOSURE. KAISER ENGINEERS 6413-11-STEP/LOFT-650-A-6. DATE: OCTOBER 1964. INEEL INDEX CODE NO. 036-650-00-486-122218.

ID-33-E-379 LOFT. CONTAINMENT AND SERVICE BUILDING (TAN-650) • ROOF PLAN AND DETAILS. KAISER ENGINEERS 6413-11-STEP/LOFT-650-A-8. DATE: OCTOBER 1964. INEEL INDEX CODE NO. 036-650-00-486-122220.

ID-33-E-380 LOFT. CONTAINMENT AND SERVICE BUILDING (TAN-650) . SOUTH ELEVATION, DETAILS, SECTION. SHOWS PART OF DUCT ENCLOSURE, RAILROAD DOOR OPENING, ROOF VENTILATORS, SHIELDED PERSONNEL ENTRANCE, AND CHANGE ROOM. SECTION F SHOWS VIEW FROM WEST LOOKING TOWARD SHIELDING AROUND AIRLOCK DOOR ON MAIN FLOOR. KAISER ENGINEERS 6413-11-STEP/LOFT-650-A-9. DATE: OCTOBER 1964. INEEL INDEX CODE NO. 036-650-00-486-122221.

ID-33-E-381 LOFT. CONTAINMENT AND SERVICE BUILDING (TAN-650) . SECTIONS $\mathrm{H}, \mathrm{K}$, AND L; DETAILS OF PRE-AMP TOWER. KAISER ENGINEERS 6413-11-STEP/LOFT-650-A-14. DATE: JANUARY 1966. INEEL INDEX CODE NO. 036-650-00-486-122226.

ID-33-E-382 LOFT. "EXPLODED VIEW" OF LOFT CONTAINMENT BUILDING (TAN-650), INCLUDING CONTROL BUILDING (TAN-630). EG\&G. FEBRUARY 1979. INEEL INDEX CODE NO. 036-010-65-220-209565.

ID-33-E-383 LOFT. CONTAINMENT AND SERVICE BUILDING (TAN-650). ROOM NUMBER AND FUNCTION OF EACH ROOM. IDENTIFIES TYPE OF FLOOR, PAINT, WALLS, CEILING, DOORS. THIS IS SHEET ONE OF A TWO-PAGE DRAWING. KAISER ENGINEERS 6413-11-STEP/LOFT-650-XX. DATE: OCTOBER 1965. INEEL INDEX CODE NO. 036-650-00-486-122228. 
ID-33-E-384 LOFT. CONTAINMENT AND SERVICE BUILDING (TAN-650) . ROOM NUMBER SCHEDULE, SHEET TWO OF TWO. KAISER

ENGINEERS 6413-11-STEP/LOFT-650-A-XX. DATE:

OCTOBER 1969. INEEL INDEX CODE NO.

036-650-00-486-122228.

Notes:

1. The historical photographs selected for this report originated in a photograph collection located at the Idaho National

Engineering and Environmental Laboratory's Photograph Archive in the Willow Creek building and the Inactive Storage Records Warehouse at Idaho Falls, Idaho. Negatives are indexed according to year, name of facility area, and sequence number.

2. The original engineering drawings for the ANP and LOFT programs were destroyed within the last ten years. The photographic copies in this report were made from microfilm aperture cards located at the Idaho National Engineering and Environmental Laboratory at the Engineering Research office Building.

3. The INEEL photographic and engineering archives date from the earliest operations at the National Reactor Testing Station. They document construction progress, events, equipment and procedures, and periodic aerial surveys of the site. Most of these resources are available for examination and reproduction.

4. For written historical and descriptive information on Test Area North, please see main entry for Idaho National Engineering Laboratory, Test Area North, HAER No. ID-33-E.

5. Additional images and illustrations may be found in the written historical report, HAER NO. ID-33-E, as accompaniments to the narrative. For the most part, these are sketches, photographs from sources other than INEEL, or copies of $35 \mathrm{~mm}$ images not practical for HAER-quality reproduction.

6. The INEEL Index Code for architectural and engineering drawings is composed of the following elements. Using the example 034-0607-00-693-106758:

034: An NRTS/INEEL "area" number. In this case, the A\&M area at Test Area North.

0607: The building or structure number at this "area."

00: Classification code. In this case, 00 signifies "architectural" drawings.

693: A code number for the originating contractor. This code number was assigned to the Ralph M. Parsons Company. 
106758: A serial number assigned by the NRTS/INEEL Document Control system. This is the only unique number in a drawing's identification elements.

7. Numbers in the 600 and 1600 ranges were assigned to buildings roughly in chronological order of their construction. When 600 numbers were consumed, the sequence continued with 1600 numbers. Structures, such as exhaust stacks and outdoor turntables, were given 700 and 1700 numbers. 